\title{
ELISABETE JUST
}

\section{Cor Mio, Coro Mio, Curumim:}

história, análise de seis peças de um repertório multicultural para coro infantil e estratégias lúdicas do Coro Curumim da Associação Cultural Cantosospeso, entre 1993 e 2003, em Milão, Itália 


\section{ELISABETE JUST}

\section{Cor Mio, Coro Mio, Curumim:}

história, análise de seis peças de um repertório multicultural para coro infantil e estratégias lúdicas do Coro Curumim da Associação Cultural Cantosospeso, entre 1993 e 2003, em Milão, Itália

Dissertação apresentada à Escola de Comunicação e Artes da Universidade de São Paulo, como exigência parcial para a obtenção do título de Mestre em Música.

Área de Concentração: Musicologia

Orientação: prof. Dr. Pedro Paulo Salles.

São Paulo 
Autorizo a reprodução e divulgação total ou parcial deste trabalho, por qualquer meio convencional ou eletrônico, para fins de estudo e pesquisa, desde que citada a fonte.

Catalogação na Publicação Serviço de Biblioteca e Documentação

Escola de Comunicações e Artes da Universidade de São Paulo Dados fornecidos pelo(a) autor(a)

Just, Elisabete

Cor Mio, Coro Mio, Curumim: história, análise de seis peças de um repertório multicultural para coro infantil e estratégias lúdicas do Coro Curumim da Assoc / Elisabete Just. -- São Paulo: E. Just, 2013.

210 p.: il.

Dissertação (Mestrado) - Programa de Pós-Graduação em Música - Escola de Comunicações e Artes / Universidade de São Paulo.

Orientador: Pedro Paulo Salles

Bibliografia

1. Coral Infantil 2. Repertório Multicultural 3. Atividades Lúdicas 4. Canto Coral 5. Cantosospeso I. Salles, Pedro Paulo II. Título. 
JUST, Elisabete. Cor Mio, Coro Mio, Curumim: história, análise de seis peças de um repertório multicultural para coro infantil e estratégias lúdicas do Coro Curumim da Associação Cultural Cantosospeso, entre 1993 e 2003, em Milão, Itália. Dissertação apresentada à Escola de Comunicações e Artes da Universidade de São Paulo para a obtenção do título de Mestre em Música junto ao Programa de Pós-graduação em Música.

Aprovado em:

Banca Examinadora

Prof. Dr. Instituição

Julgamento Assinatura

Prof. Dr. Instituição Julgamento Assinatura

Prof. Dr. Instituição Julgamento Assinatura 


\section{AGRADECIMENTOS}

A Deus, o TODO que está em tudo.

Às crianças e equipe de trabalho do Coro Curumim, aos coralistas da Associação Cultural Cantosospeso, à Sociedade Umanitaria, ao Maestro Martinho Lutero Galati de Oliveira e à maestrina Claudia Regina Costa.

Ao Prof. Dr. Pedro Paulo Salles, pela orientação, colaboração, paciência, prontidão, que com seu olhar "pitagórico" piagetiano norteou os processos, plantou sementes, apoiando em todos os momentos do percurso.

À Maísa Intelisano, amiga e revisora atenta deste trabalho.

Ao Prof. Dr. Fábio Cintra e ao Prof. Dr. Ivan Vilela, pelas sugestões, observações e críticas construtivas feitas no Exame de Qualificação.

Aos professores do Departamento de Música, da graduação e da pós-graduação, cujas disciplinas e conversas informais foram fundamentais em minha formação musical e humana.

Aos amigos e familiares, sobretudo minha mãe, que apoiaram, estimularam e entenderam o afastamento necessário para este trabalho. 


\section{RESUMO}

Esta dissertação pretende apresentar um histórico contextualizado e comentado de trabalho de coro infantil realizado em Milão, na Itália, com o Coro Curumim da Associação Cultural Cantosospeso, entre 1993 e 2003, assim como um estudo sobre as estratégias lúdicas utilizadas e a concepção de seu repertório multicultural de canções. Ressaltando a importância dessas estratégias lúdicas, tanto para o trabalho mais técnico, voltado aos modos de cantar tal repertório, como para a compreensão sociocultural do cantar e do fazer musical em geral, sobretudo no âmbito que circunscreve a concepção musical e sociocultural de cada povo contemplado nas canções que compreendem o cancioneiro empregado e das próprias crianças envolvidas, pretendeu-se contribuir para o desenvolvimento da área de canto coral infantil e, por que não dizer, da educação musical, e compartilhar com regentes corais, educadores musicais e estudantes de música, principalmente, uma experiência que consideramos formadora e transformadora.

Palavras-chave: Coral Infantil, Atividades Lúdicas, Repertório Multicultural, Canto Coral, Cantosospeso. 


\begin{abstract}
This dissertation aims to provide a contextualized, commented history of a children's choir work performed in Milan, Italy, with the Curumim Choir, a group of Cantosospeso Cultural Association, between 1993 and 2003, as well as a study on the ludic strategies used and the design of its multicultural songs repertoire. Underscoring the importance of these ludic strategies for both the more technical work, focused on ways to sing this repertoire, and the sociocultural understanding of singing and music making in general, especially in the context that circumscribes both the musical and the sociocultural conception of every people contemplated in the songs that comprise both the repertoire employed and the children involved, it is intended to contribute to the development of the children's choir area, why not say, music education, and share with choir directors, music educators and music students, mainly, an experiment we consider formative and transformative.
\end{abstract}

Keywords: Children's Choir, Ludic Activities, Multicultural Repertoire, Choral Singing, Cantosospeso. 


\section{SUMÁRIO}

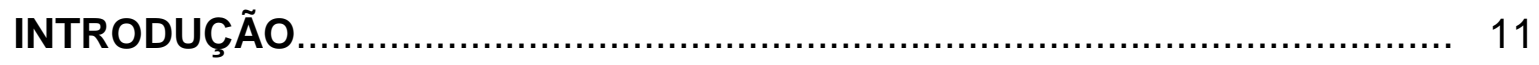

\section{CAPÍTULO 1 - CONTEXTO DO CORO CURUMIM: A ASSOCIAÇÃO CULTURAL CANTOSOSPESO E OS PROJETOS INFANTIS CURUMIM...... 16}

1.1. Associazione Culturale Cantosospeso (ACC) - seu Diretor Artístico......... 17

1.1.1. Grupos Corais da ACC.......................................................... 19

1.1.2. Grupos de Apoio às Atividades Corais....................................... 28

1.2. Projetos Infantis Curumim (PIC)............................................................. 29

1.2.1. Coro Curumim entre 1993 e 2003 ............................................ 36

1.2.2. Atividades Paralelas aos Grupos Corais do PIC.......................... 51

\section{CAPÍTULO 2 - ANÁLISE DE SEIS PEÇAS PARA CORO INFANTIL EXTRAÍDAS DO REPERTÓRIO MULTICULTURAL DO CORO CURUMIM..... 60}

2.1. As Motivações, Fontes, Comentários, Textos, Traduções em Português e Aspectos Musicais de Seis Canções para Coro Infantil do Coro Curumim...... 63

2.1.1. Bella Ciao........................................................ 63

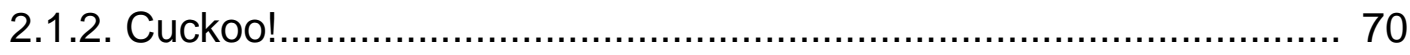

2.1.3. Das Klinget so Herrlich.......................................... 78

2.1.4. Mekô Merewá..................................................... 84

2.1.5. N'Kosi Sikeleli Africa................................................ 92

2.1.6. Tzun Tiãn Lai..................................................... 98

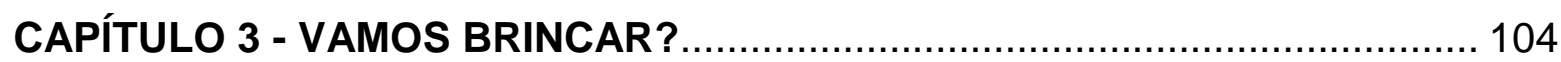

3.1. A Maestrina Brincando de Educadora.................................................. 105 
3.2. Dançando com Huizinga e Spolin: aspectos Lúdicos em Homo Ludens, em O jogo teatral no livro do Diretor e no Coro Curumim.................................. 107

3.3. Desenhando os Momentos do Ensaio ........................................................ 113

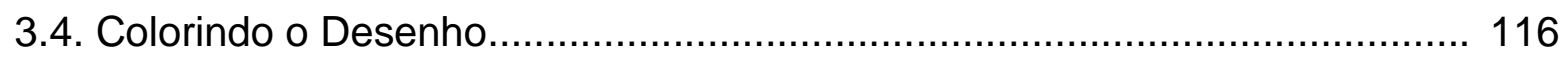

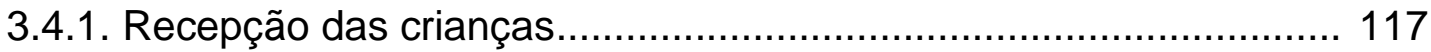

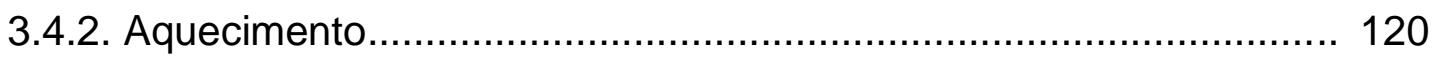

3.4.3. Introdução aos Conceitos Musicais............................................. 123

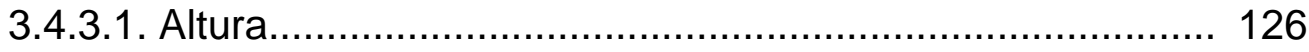

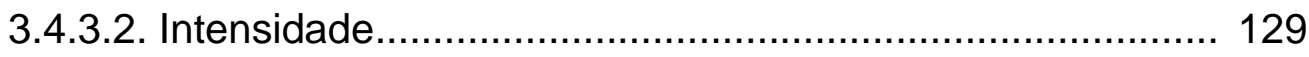

3.4.3.3. Timbre..................................................................... 130

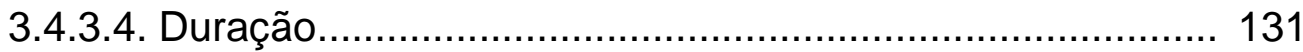

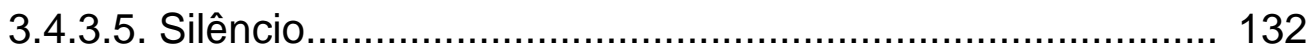

3.4.3. Atividades Lúdicas Dirigidas ao Repertório.................................. 133

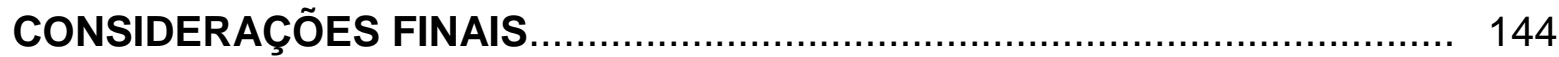

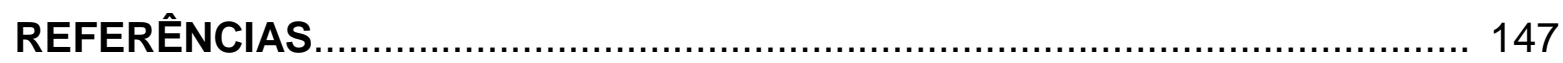

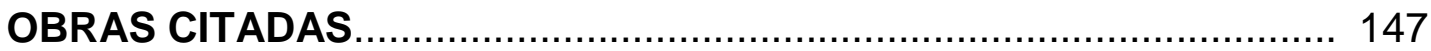

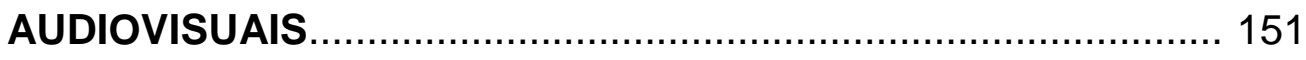

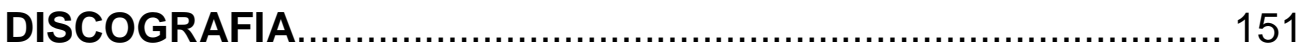

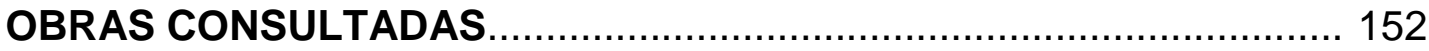

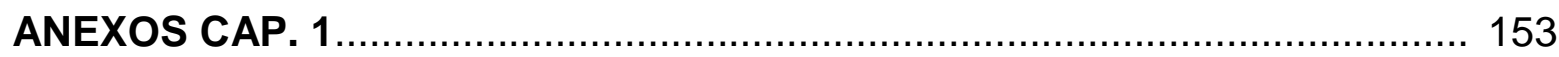

ANEXO A - Programa do Concerto Boas Festas................................................... 154

ANEXO B - Programa do Concerto Saluba..................................................... 155

ANEXO C - Curso de férias em parceria com a escola de música /l Classico........... 156

ANEXO D - Calendário de ensaios e da apresentação do espetáculo

Tele e Visione ......................................................................................... 157

ANEXO E - Capa do programa de sala do espetáculo Girotondo............................. 158

ANEXO F - Ensaios extras para os espetáculos Tele e Visione e Girotondo............ 159

ANEXO G - Publicidade do Coro Curumim em parceria com a Società Umanitaria... 160 
ANEXO H - Primeira chamada do Coro Curumim em 1996 no TG CORO................ 161

ANEXO I - Resumo das atividades do Coro Curumim em parceria com a SU.......... 162

ANEXO J - Coro Curumim do ano letivo 1997/1998............................................ 163

ANEXO K - Equipe de trabalho no ano letivo 1997/1998_.................................... 164

ANEXO L - Publicidade e parte do roteiro da peça I/ Negozio dei Giocattoli.............. 165

ANEXO M - Apresentação de conclusão do ano letivo 1998/1999........................... 166

ANEXO N - Nome das crianças do Coro Curumim no ano letivo 1998/1999............. 167

ANEXO O - Concerto Mille Voci per la Pace........................................................ 168

ANEXO P - Programa de sala do Happening Corale con le Scuole............................ 169

ANEXO Q - Certificado de participação ao Happening Corale con le Scuole............ 170

ANEXO R - Apresentação de conclusão do ano letivo 1999/2000 ........................... 171

ANEXO S - CD Festa! e autorização de uma criança, Carlotta Broglio, para

participar da gravação................................................................................... 172

ANEXO T - Publicidade do Coro Curumim em Via Sforza, Milão, na

Libreria Claudiana

ANEXO U - Capa do programa de sala do espetáculo Vamos Brincar.

ANEXO V - Capa do programa das atividades em Quattro giorni nei dintorni

di Bahia.

ANEXO W - Programação das atividades em Quattro giorni nei dintorni di Bahia.... 176

ANEXO X - Programa de sala do concerto IN-CANTO........................................... 177

ANEXO Y - Programa do concerto Messa Luba com Kambilolo Group.................... 178

ANEXO Z - Publicidade de Girotondi e Filastrocche............................................. 179

ANEXO AA - Atividades do laboratório de férias, Pincopallino, em 1998.................. 180

ANEXO BB - Comprovante de pagamento das atividades realizadas no laboratório

de férias em 1998........................................................................... 181

ANEXO CC - Publicidade do laboratório de férias, Pincopallino, em 2000................ 182

ANEXO DD - Percurso do laboratório de férias em 2002 ..................................... 183

ANEXO EE - Programação do primeiro dia de atividades no Pincopallino 2002....... 184

ANEXO FF - Idade das crianças dos laboratórios de férias em 2002 ........................ 185

ANEXO GG - Objetivos do laboratório de férias em 2000 ...................................... 186

ANEXO HH - Anotações sobre o início do laboratório Fiabe e Suoni Amazzonici..... 187

ANEXO II - Adaptação em italiano, livre e resumida, feita pela mestranda do conto

O menino que não sabia sonhar, de Daniel Munduruku.......................................... 188

ANEXO JJ - Esboço do cenário do laboratório Fiabe e Suoni Amazzonici................ 190 
ANEXO KK - Número de crianças das atividades infanto-juvenis da SU

em 2001/2002

ANEXOS CAP. 2.

ANEXO LL - Partitura de Bella Ciao (1) ............................................................. 193

ANEXO MM - Partitura de Bella Ciao (2)........................................................ 194

ANEXO NN - Partitura de Cuckoo! (1) ............................................................. 195

ANEXO OO - Partitura de Cuckoo! (2)............................................................ 197

ANEXO PP - Partitura de Das Klinget so Herrlich.................................................... 199

ANEXO QQ - Partitura de Mekô Merewá (1)....................................................... 200

ANEXO RR - Partitura de Mekô Merewá (2) ....................................................... 201

ANEXO SS - Partitura de N'Kosi Sikeleli Africa (1) ............................................ 202

ANEXO TT - Partitura de N'Kosi Sikeleli Africa (2)................................................ 203

ANEXO UU - Letra de Tzun Tiãn Lai em mandarim e tradução em português

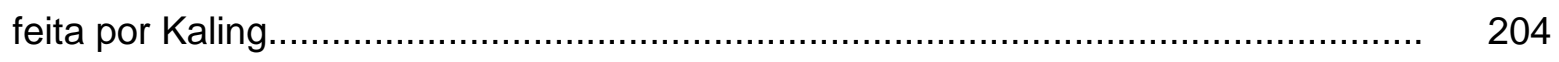

ANEXO VV - Romanização no sistema Pinyin e letra em mandarim de Tzun Tiãn Lai, realizado por Chen Lijin................................................................................. 205

ANEXO WW - Partitura de Tzun Tiãn Lai (1)...................................................... 206

ANEXO XX - Partitura de Tzun Tiãn Lai (2)................................................... 207

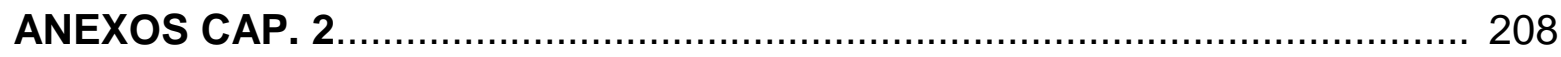

ANEXO YY - Jogo da Memória................................................................. 209

ANEXO ZZ - Depoimentos das crianças do Curumim......................................... 210 


\section{INTRODUÇÃO}

\section{Cor Mio, Coro Mio, Curumim...}

Cor mio (meu coração) é uma homenagem à peça coral homônima do mestre madrigalista Claudio Monteverdi (Cremona, 1567 - Veneza, 1643), renascentista para alguns, barroco para outros, para nós, um compositor atemporal que soube transformar sentimentos e emoções em música, trazendo novas luzes à musicalidade das dissonâncias e à harmonia em geral na construção musical.

Coro mio (meu coro) era a maneira pela qual Virgilio, uma das crianças do nosso coro infantil dos quatro aos treze anos, pronunciava o nome do coro. Sim, o coro era seu, era de todos os curumins e "curumões" que vivenciariam cada etapa desse coro infantil, participando e contribuindo com suas particulares expressões.

Curumim, menino, em tupi-guarani, era o nome do nosso coro, comum aqui no Brasil e instigante em terras italianas.

A primeira frase da música de Monteverdi "Cor mio, mentre vi miro, visibilmente mi trasformo in voi" (Meu coração, enquanto vos olho, me transformo em vós de modo visível), expressa nossa vivência com o Coro Curumim, com as crianças, com a equipe de trabalho, com os diversos colaboradores, na troca de saberes e experiências de vida transformadoras, no impulso para o crescimento a partir da atividade artística e dos relacionamentos afetivos. Curumim, coro mio, foi o nosso coro, o coro de cada criança e adulto que, a um só tempo, absorveu, compartilhou e transformou suas experiências de vida no jogo coral e na convivência musical. Convivência essa organizada na medida em que a realização do canto, em conjunto, de um repertório multicultural era reconhecida pelos participantes como momento mágico e proveitoso, tanto no sentido social como no musical.

As ideias contidas nesta dissertação nascem em tempos distantes, partilhando também da história de vida da mestranda. Por ser filha de imigrante teuto-ucraniano e descendente de avós romenos, afilhada de libanesa, sobrinha de espanhóis e 
indígenas brasileiros, prima de peruana, frequentadora, na infância, da casa de amigos japoneses, portugueses, italianos, judeus franceses; por ter lido, quando criança, as histórias de Caroline, uma menina que viajava pela África e pela América do Sul em companhia de seus animais; por ter estudado piano e ouvido músicas de diversos povos; por tudo isso, buscou um país estrangeiro para o projeto e optou por um repertório musical multicultural.

O projeto inicial, ao sair do Brasil em 1990, era o de fazer uma experiência de seis meses em cada país da Europa, em busca das expressões culturais de cada povo, sobretudo sua música. Esse projeto, a princípio um tanto megalômano, principalmente vindo de uma jovem recém-formada, se demonstrou impossível, mas as portas que procurávamos se abriram de outra maneira: conhecemos uma associação cultural que nos trouxe mais que o contato com o diverso, ofereceu-nos a vivência de um mundo "dai mille volti, dai mille colori e dai mille canti" (slogan da Associazione Culturale Cantosospeso nos anos noventa), por meio da prática coral.

A ideia de escrever sobre atividades lúdicas no canto coral nasceu em fins dos anos oitenta, em um curso sobre como escrever uma dissertação de mestrado, com o Prof. Sérgio Figueiredo, então professor da $\mathrm{FAAM}^{1}$, fruto de observações do universo coral em que vivíamos. Logo em seguida, a mudança para a Itália possibilitou que construíssemos uma experiência prática, com jogos dirigidos ao coro infantil, jogos esses intuitivos, porém reflexo da formação musical, pedagógica e coral anterior, acrescida de novas práticas.

A oportunidade de estudar essas atividades lúdicas dirigidas à interpretação de um repertório multicultural para coro infantil surgiu em 2004, ao entrar no programa de pós-graduação desta instituição sob a orientação do prof. Dr. Marco Antonio da Silva Ramos, que foi interrompida devido à doença e a posterior partida de meu pai, em 2007. Somos gratos ao professor Marco Antonio pelos anos de aprendizado e incentivo no início dos estudos para esta dissertação, e mencione-se que preservamos o uso de seu referencial de análise para obras corais no segundo capítulo, assim como a sugestão de algumas obras de referência.

\footnotetext{
${ }^{1}$ Faculdade de Música Alcântara Machado.
} 
Os anos passaram, mas a caixa de papelão com o material da dissertação continuava a indagar pelo retorno ao trabalho. Nesse meio tempo, redescobrimos nossa parte compositora, criamos canções, criamos um quarteto feminino com músicas espirituais universalistas, criamos um dueto, demos aulas de piano e de canto, mas a caixa de papelão continuava a nos olhar suplicante... Em 2010, fomos estimulados a retornar ao curso de mestrado pelo amigo violeiro Ivan Vilela, professor desta mesma instituição e, após refazer os exames de admissão para o mestrado em 2011, passamos nos testes e fomos aceitos pelo atual orientador.

Nesse caminho tortuoso, se, por um lado, nos afastamos, por vezes, do estudo teórico, por outro, abriram-se novas espirais de conhecimento, de práticas musicais e de vida, renovando o olhar para novas empreitadas de pensamento e pesquisa que viriam pela frente.

Esta dissertação é a fotografia de um intenso momento, da experiência do Coro Curumim com regentes corais infantis e educadores musicais, na qual as pessoas envolvidas revivem sua história, suas músicas em repertório multicultural, suas atividades lúdicas, agora passadas por um processo de análise e interpretação.

$\mathrm{Na}$ paisagem dessa foto, está impressa a Itália das crianças e colegas colaboradores, como também estão os informantes e professores que trouxeram, nesses anos de disciplinas e orientação na Universidade de São Paulo, as bases teóricas e metodológicas necessárias à realização deste estudo.

\section{Objetivos e Estruturação deste Trabalho}

A intenção principal deste trabalho é compartilhar as experiências vividas no Coro Curumim, o modo de fazer coro infantil com repertório multicultural permeado por estratégias lúdicas, de maneira que possa servir como material de consulta para regentes de coros infantis, educadores musicais e estudantes de música. Aqui, é relatada a trajetória do Coro Curumim da Associação Cultural Cantosospeso (ACC), em Milão, Itália, entre os anos de 1993 a 2003, com foco nas estratégias lúdicas, utilizadas 
para a realização de um repertório multicultural para canto coral infantil, e para este mesmo repertório e seu propósito.

Tendo-se passado 10 anos desde os últimos ensaios com o Coro Curumim e da participação direta da mestranda nas funções de regente e coordenadora das atividades infantis, hoje o tempo desloca e redireciona esses papéis para o de pesquisadora e, por assim dizer, de narradora, e desloca também o prisma de uma abordagem prática para aquele que permeia o olhar analítico, memorial e documental. Nesse sentido, foi de suma importância o trabalho com as fontes documentais e bibliográficas, e o diálogo que travaram com nossa prática, revigorando nossas concepções e reafirmando a crença de que um trabalho musical pode ser significativo e transformador.

No sentido de situarmos estas experiências e as análises que se seguem em um discurso favorável à reflexão e inteligível para leitor, dividimos o trabalho em três capítulos:

1) O primeiro capítulo contextualiza as operações socio-artísticas e culturais da ACC e os Projetos Infantis Curumim (nome criado nesta dissertação para abarcar as diversas atividades infantis, incluindo o Coro Curumim). Descrevemos a ACC, sobretudo com base na memória pessoal da mestranda e de informantes que atuaram na época, apresentando uma breve contextualização da cidade de Milão naqueles anos e a trajetória do PIC através da memória e de documentos organizados e dispostos em anexos, tais como programas de concerto, publicidades (de divulgação), fotos, partituras, anotações informais etc.

2) O segundo capítulo apresenta a análise musical de seis peças escolhidas do repertório multicultural do Coro Curumim. São elas Bella Ciao, Cuckoo!, Das Klinget so Herrlich, Mekô Merewá, N’Kosi Sikeleli Africa e Tzun Tiãn Lai. O fato de enfatizarmos o sentido de um repertório multicultural e os processos que envolveram sua prática, sem mencionar a descrição minuciosa do contexto sociocultural e institucional desses processos, denota o uso de uma metodologia qualitativa e de um olhar cultural.

3) No terceiro capítulo, estudamos alguns conceitos e modalidades de jogo e brincadeira em contexto pedagógico, visando à análise de nossas práticas com as crianças, sobretudo no que tange as atividades lúdicas que desenvolvemos para os 
ensaios - dirigidas para o aprendizado de elementos musicais - o desenvolvimento da percepção, o trabalho de técnica vocal, a compreensão das músicas de diferentes culturas, seu texto e sua forma de cantar. Nele, são analisadas as atividades musicais e suas estratégias lúdicas usadas pela regente e a equipe de trabalho nos ensaios do Coro Curumim, tendo, como principais referências teóricas, Johan Huizinga, Viola Spolin e Pedro Paulo Salles. Finalizamos o capítulo com sugestões de atividades lúdicas dirigidas à contextualização de um repertório multicultural e ao desenvolvimento de habilidades inerentes ao canto coral infantil. 


\section{CONTEXTO DO CORO CURUMIM: A ASSOCIAÇÃO CULTURAL CANTOSOSPESO E OS PROJETOS INFANTIS CURUMIM}

O Coro Curumim da Associazione Culturale Cantosospeso (ACC) ${ }^{2}$ de Milão, Itália, passou por diversos momentos desde a sua fundação em 1993, no que se refere à formação humana (crianças e equipe de trabalho), número de grupos corais simultâneos, músicas do repertório multicultural, atividades extras aos ensaios (performance em concertos corais, espetáculos de teatro, apresentações aos pais, gravação em estúdio) etc., em que objetivos artísticos, sociais e pedagógicos também variavam em concordância com as contingências.

O Curumim teve o suporte de várias atividades infantis extras, tais como laboratórios musicais para crianças nas férias, preparação dos pequenos para cantar em peças de teatro, espetáculos de música e teatro infantil, concertos infanto-juvenis, palestra sobre a infância no Brasil. Essas atividades serviram para a formação da equipe de trabalho infantil, de incentivo aos curumins (que recebiam diretamente as informações ao assistirem às atividades, e/ou as recebiam em segunda mão, através da equipe de trabalho), e como publicidade para que viessem mais crianças para os coros infantis.

Para facilitar a compreensão da interligação entre essas atividades voltadas às crianças, criamos, nesta dissertação, o nome Projetos Infantis Curumim ${ }^{3}$ (PIC), que engloba as atividades expostas acima, ou seja, o conjunto de grupos corais e atividades infantis paralelas (laboratórios musicais, concertos corais, apresentações de teatro etc.), entre os anos de 1993 e 2003, na Itália.

Todas as atividades do PIC tiveram a direção artística do maestro Martinho Lutero, excetuando os laboratórios de verão na Società Umanitaria ${ }^{4}$ (SU) e a

\footnotetext{
${ }^{2}$ Usaremos a sigla ACC para nos referirmos à Associazione Culturale Cantosospeso.

${ }^{3}$ Referido neste trabalho com a sigla PIC.

${ }^{4}$ Società Umanitaria, a que, daqui em diante, nos referiremos com a sigla SU, é reconhecida por decreto régio, em 1893, como instituição pública de assistência e beneficência, situada em Milão, Itália. Foi criada em 1892 por Prospero Moisè Loria, um mecenas milanês, que nominou essa instituição como sua herdeira universal. Desde meados dos anos noventa do século passado, a ACC estabelece parcerias com a SU.
} 
preparação das crianças da escola de Gratosoglio para o espetáculo Girotondi e Filastrocche (Cirandas e Parlendas) abordado no item 1.2.2 deste capítulo.

As atividades do PIC estão em sintonia com as propostas sociais, artísticas e culturais da ACC, e também na escolha do repertório, e sua equipe de trabalho foi formada por regentes e cantores dos coros da ACC. Portanto, para conhecer o trabalho do PIC, é imprescindível um breve relato sobre o Maestro Martinho Lutero Galati de Oliveira $^{5}$, e a ACC e seus grupos, do seu nascimento, em 1987, a 2003.

Além do que foi exposto no parágrafo anterior, é relevante o fato de que a mestranda, coordenadora das atividades infantis da ACC entre 1995 e 2003, esteve ao lado do maestro, desempenhando diversas funções dentro dessa associação, entre 1991 e 2003.

\title{
1.1. Associazione Culturale Cantosospeso (ACC) - seu Diretor Artístico
}

\begin{abstract}
A Associação Cultural Cantosospeso, fundada em 1987, em Milão, tem, entre seus objetivos, a difusão da prática coral como exercício de convivência social e aproximação com o universo musical. Sua atenção é particularmente voltada aos cantos que estão no limite do esquecimento; os cantos que pertencem aos povos que não puderam sobreviver e àqueles que estão se consumindo lentamente, sufocados pelas guerras, pelo desenvolvimento tecnológico, pelo colonialismo cultural ou pelas rígidas leis de mercado.

A Associação procura dar voz a essas culturas, para mantê-las vivas na memória e restituir, a nós todos, a riqueza de diversos modos de pensar.

Cantar quer dizer estar em harmonia com as pessoas, em um jogo de respeito e enriquecimento recíproco. Escutar significa conhecer: o conhecimento sensível dos oprimidos e das restrições que determinam o sofrimento do homem possibilita sua superação da realidade.

Criada pelo Maestro Martinho Lutero Galati de Oliveira, a Associação é inspirada pelos princípios musicais, estéticos e filosóficos de seu professor, Luigi Nono. (CANTOSOSPESO, 2013, tradução nossa)
\end{abstract}

\footnotetext{
${ }^{5}$ Martinho Lutero Galati de Oliveira (Alpercatas, MG - 1953), é um maestro ítalo-brasileiro, autor do livro Do gesto à gestão: um diálogo sobre maestros e liderança, em coautoria com a maestrina Rita FucciAmato. Entre tantas atividades artísticas, exerce a função de diretor artístico da ACC de Milão, Itália, e da Rede Cultural Luther King, de São Paulo, Brasil.
} 
Além de idealizador, o maestro Martinho Lutero também é diretor artístico da ACC. Suas características pessoais, tais como formação musical e o fato de ter vivido e criado associações culturais em três continentes ${ }^{6}$ (América do Sul, África e Europa), se integram harmoniosamente na prática de canto coral vivenciada como atividade artística e socializadora, cujo objetivo principal é o fazer musical de um repertório multicultural.

Lutero, como é conhecido em seus grupos, é um líder capaz de abrigar e estimular grande contingente de pessoas em sintonia com os ideais de suas associações culturais, sejam participantes ativos no interior dessas (coralistas, estudantes e profissionais da música, chefes de naipe, assistentes, regentes, e outras tantas funções, dependendo dos objetivos do momento, tais como espetáculos, concertos, palestras etc.), sejam colaboradores externos dos mais variados setores culturais (artistas, professores, historiadores, pesquisadores etc.). Mais do que um agitador cultural, é um condensador de tendências culturais divulgadas, atualmente, por meio de suas duas associações culturais (a ACC, em Milão, Itália, e a Rede Cultural Luther King ${ }^{7}$, em São Paulo, Brasil), e por seus diversificados trabalhos musicais.

A mestranda foi uma dessas pessoas que trabalharam e foram estimuladas pelo maestro durante quase treze anos, na condição de aluna particular de música (teoria, leitura musical, contraponto, harmonia, regência e composição de arranjos corais); como sua assistente em diversos coros e, com o tempo, responsável pela regência e coordenação de grupos, em um trabalho cotidiano, em que práxis e teoria se alimentam uma à outra, em que observação, reflexão e prática caminham juntas na aquisição e propagação de conhecimentos; e no exercício diário da convivência social, do diálogo, do compartilhar, transformar, organizar, harmonizar, enfim, vivendo e desenvolvendo essas qualidades inerentes ao mundo coral.

Os grupos que dão origem à Associação se iniciam em 1987 (dois grupos corais e um de dança, coordenado pela coreógrafa Felisa Alvear Pineda), e foram oficialmente formalizados em estatuto em 1991, no qual o coro principal ganhou o nome

\footnotetext{
${ }^{6}$ Em São Paulo, Brasil, criou a Rede Luther King; em Moçambique, África, o Tchova Xita Duma (nome de um carrinho típico de Moçambique, puxado a mão, que leva produtos, bens, e até pessoas); em Milão, Itália, a Associazione Culturale Cantosospeso.

7 A Rede Cultural Luther King, criada pelo maestro Martinho Lutero em 1971, continua em vigor até nossos dias. Seu nome rende homenagem ao pacifista e pastor protestante norte-americano Martin Luther King. Em 2012, o Coro Luther King, que representa essa rede cultural, ganhou o prêmio APCA de melhor coro erudito.
} 
da recém-formada associação cultural. Ao longo desses anos até a metade de 2003, ano em que a mestranda retorna ao Brasil, além da criação de novos grupos corais e de atividades específicas para esse tipo de formação musical, ela também participou e/ou promoveu encontros envolvendo diferentes áreas de expressões artístico-culturais. Dentre essas atividades, citamos cursos, palestras, colaborações com grupos corais e músicos externos; concertos e turnês em diversas cidades do Brasil, Itália, Burkina Faso, França, Alemanha, Suíça, Cuba e Portugal; participação em peças de teatro; sonorização ao vivo de projeção cinematográfica; exposição de pintura. Fazem parte também da ACC, ações solidárias, como a colaboração com o coro infanto-juvenil queniano do professor Kazungo, o Kambilolo Group, iniciada em 1994, arrecadando fundos para a construção de uma escola em Watamu, Quênia, e assistência sanitária para a região (FUCCI-AMATO; GALATI, 2013, p. 154).

Segue um pequeno histórico dos grupos corais e grupos de apoio diretamente relacionados a eles até o ano de 2003.

\subsubsection{Grupos Corais da ACC}

Coro Mensagem, atual Coro Cantosospeso (a partir de 1991)

Nasce, em 1987, com o objetivo de desenvolver o repertório vocal em língua portuguesa, compreendendo a música renascentista portuguesa, a música colonial e contemporânea brasileira, e as músicas africanas dos países colonizados por Portugal, sendo o repertório de música renascentista desenvolvido com poucas pessoas do coro, respeitando as exigências estilísticas do mesmo. Ainda como Coro Mensagem (referência direta ao livro homônimo de Fernando Pessoa), alarga seus interesses integrando ao seu repertório músicas afroamericanas. Como Coro Cantosospeso (nome 
originário de uma composição de Luigi $\mathrm{Nono}^{8}$ - /l Canto Sospeso), realizava um repertório multicultural, compreendendo músicas das mais variadas culturas e estilos musicais, escritas ou arranjadas para coros a quatro vozes mistas, com entre 40 e 50 pessoas.

O coro era composto por uma equipe técnica de profissionais e profissionais em formação (regente, regente-assistente, ensaiadores de naipe) ${ }^{9}$, e por coralistas amadores incentivados a se alfabetizarem musicalmente e a desenvolverem seus potenciais vocais por meio dos cursos e professores sugeridos pela ACC.

Além dos dois ensaios semanais de duas horas cada um, como coro performático realizava em torno de dois concertos mensais, turnês nacionais e internacionais, e seus integrantes realizavam workshops de preparação de repertório ao menos duas vezes por ano ${ }^{10}$.

Para participar desse grupo, era exigido dos coralistas que o considerassem "hobby principal", ou seja, que estivesse em primeiro plano, antes de interesses pessoais como família e trabalho, pois só assim seria possível terem a disponibilidade de tempo e a flexibilidade necessárias às exigências das atividades propostas no grupo.

\footnotetext{
${ }^{8}$ Luigi Nono (Veneza, 1924-1990). Compositor italiano do séc XX, "estudou música com Malipiero e Bruno Maderna nos anos em que a sociedade e cultura italianas estavam marcadas por um profundo desejo de renovação. Com essa perspectiva, ele soube, de maneira inteligente, observar a tradição e, ao mesmo tempo, manter-se atento em denunciar toda rigidez acadêmica, mesmo entre os movimentos de vanguarda." (LA GARZANTINA, 2002, p. 601, tradução nossa).

Segundo Paul Griffiths, foi um dos primeiros jovens compositores do pós-guerra, ligado a Boulez e Stockhausen nas experiências de serialismo integral do início dos anos 50, a compor uma ópera. "Já nessa época, entretanto, ele expressava, vigorosamente, em numerosas obras, seus ideias humanitários de artista sensível e comunista engajado. Sua violência, contudo, vinha sempre equilibrada por um lirismo tipicamente italiano, notadamente na cantata I/ Canto Sospeso (O canto suspenso, 1956), que trata questões atuais em dinâmico aproveitamento das palavras de presos políticos." (GRIFFITHS, 1987, p. 169).

${ }^{9}$ O número e as funções dos componentes refere-se ao que geralmente fez parte da realidade ocorrida entre 1987 e 2003, considerando a variação causada pela rotatividade inerente à atividade coral amadora.

${ }^{10}$ Lembro-me de um desses workshops em que fizemos a preparação de Membra Jesus Nostri de Dietrich Buxtehude: três dias na montanha, com atividades pela manhã, à tarde e à noite, e "buracos" na programação para quem se atrevesse a esquiar, quisesse passear pela simpática cidadezinha e conversar, conhecer de perto os companheiros de canto, fazer novas amizades, brincar com os filhos dos coralistas. Esses workshops ofereciam, além da função musical de preparação aprofundada do repertório, uma oportunidade de construir um grupo rico em significados humanos e desenvolver relações afetivas.
} 


\section{Coro 1492}

Criado em 1987, o Coro 1492 focalizava seu estudo principalmente sobre o repertório vocal renascentista europeu, alternando o estudo de compositores consagrados do período - Giovanni Pierluigi da Palestrina, Orlando di Lasso, Clement Janequin, Claudio Monteverdi - com a análise de obras de autores ainda pouco divulgados na época - Filippo Azzaiolo, Adriano Banchieri, Matteo Flecha el Viejo. Seu repertório também abrangia composições contemporâneas europeias e latinoamericanas, incluindo obras dos grandes compositores brasileiros Aylton Escobar e Almeida Prado ${ }^{11}$.

O coro era composto por regente, regente-assistente e doze cantores profissionais ou estudantes de música em vias de profissionalização.

Nasceu com o intuito de realizar o espetáculo Memorias del Fuego, inspirado na trilogia homônima do escritor e jornalista uruguaio Eduardo Galeano ${ }^{12}$, espetáculo apresentado em Milão, Gênova, Florença e outras cidades italianas, com músicas da renascença portuguesa e espanhola, ganhando, então, o nome 1492, ano em que se inicia a conquista das Américas.

Assim como o Coro Cantosospeso, ensaiava duas vezes por semana e também realizava turnês e workshops de preparação de repertório ao menos duas vezes por ano.

Nesse coro, eram trabalhadas, de maneira minuciosa, as nuances musicais, uma vez que seus componentes eram profissionais ou estudavam para se tornarem profissionais, geralmente formados na ACC. Os ensaios e os resultados musicais eram de alto nível e, por isso, a condição para participar do grupo era a de também fazer parte do Coro Cantosospeso ou de outro coro da ACC, em que esse coralista

11 Do querido "enfant terrible" Aylton Escobar (1943), profícuo compositor e professor do departamento de música da ECA-USP, fizemos a Missa Orbis Factor; do compositor José Antonio Rezende de Almeida Prado (1943 - 2010), estudamos Oráculo, obra coral a capela com texto em latim, fragmento da IV Bucólica de Virgilio.

12 Eduardo Galeano (Montevidéu, Uruguai, 1940) escritor e jornalista uruguaio. Suas obras-primas são As Veias Abertas da América Latina e Memória do Fogo, trilogia iniciada em seu exílio na Espanha. Em 1985, com a redemocratização de seu país, Galeano retornou a Montevidéu, onde vive até hoje. 
"privilegiado" pudesse compartilhar e multiplicar sua experiência e conhecimento musical.

\section{Coro Fabalalavos}

Criado em 1992, é o coro escola da ACC. Nasce para atender à demanda de coralistas que sentiam dificuldade em acompanhar o ritmo de aprendizado do Coro Cantosospeso e de novos ingressantes que fossem inexperientes em canto coral.

Seu nome provém do dialeto milanês e quer dizer, literalmente, faz bailar a voz. Era um curso com duração de um a dois anos, dependendo do desenvolvimento individual e, como a cada ano era um grupo diferente, sua equipe técnica era escolhida de acordo com as exigências do grupo em andamento, mantendo constante apenas as presenças de um regente e de um regente-assistente ${ }^{13}$.

No "Faba", apelido carinhoso dado pelos primeiros integrantes, eram oferecidas aulas de técnica vocal, compreensão elementar dos signos musicais escritos em partituras e introdução ao canto coral, com um repertório simples, adequado ao grupo vigente e representativo de vários estilos da música coral, visando um conhecimento geral das possibilidades dessa formação musical.

Nesses ensaios semanais de duas horas, em torno de trinta por ano, além das atividades acima descritas, eram convidados cantores e regentes de coros externos à ACC para conversarem sobre seus trabalhos, e realizados ao menos dois encontros com uma profissional de Feldenkrais ${ }^{14}$, Laura Inzoli, coralista da ACC, propondo exercícios dessa técnica com foco na expressão vocal.

Os cantores do Faba eram convidados a participar de todas as atividades promovidas pela ACC: assistir aos ensaios dos outros grupos; assistir aos concertos ou ajudar na produção dos mesmos; participar de palestras; encontros com coros externos

\footnotetext{
${ }^{13}$ No primeiro ano, o regente oficial era Lutero e a mestranda, sua assistente. A partir de 1993, a mestranda assume a direção do grupo, contando com a assistência de Claudia Regina Costa a partir de 1996.

14 O método Feldenkrais foi criado pelo Dr. Moshe Feldenkrais. É um método de conscientização física que propicia eficiência e economia dos movimentos que integram o dia a dia.
} 
ou com músicos, jornalistas, historiadores etc.; e eram também convidados a cantar em ao menos um dos concertos da ACC.

Ao término de um ano, com algumas exceções ${ }^{15}$, o coralista estava apto a integrar um dos outros grupos da ACC, desde que suas qualidades vocais correspondessem às necessidades dos coros, ou a procurar um coro externo.

\section{Coro Vù Cantà}

Esse coro, criado em 1992 e findo em 1998, nasceu para interpretar o repertório tradicional dos vários países de seus integrantes, na grande maioria extracomunitari, ou seja, não pertencentes à então Comunidade Comum Europeia ${ }^{16}$.

Seu nome deriva de uma expressão pejorativa usada na Itália para designar os vendedores ambulantes africanos que, devido ao sotaque, em vez de perguntarem "vuoi comperare?" (quer comprar?), se expressavam com a corruptela "vù cumprà? ".

Fez seu primeiro concerto em maio de 1993, apresentando uma versão da Missa dos Quilombos, com música de Milton Nascimento e palavras de Dom Pedro Casaldáliga $^{17}$, na Basilica di San Lorenzo alle Colonne, em Milão.

Sua equipe técnica, dependendo do ano, era basicamente composta de regente, regente-assistente e ensaiadores de naipe.

${ }^{15}$ As exceções eram aqueles cujas dificuldades de emissão vocal não eram sanadas em apenas um ano de experiência coral. Nesses casos, foram realizados atendimentos particulares e os coralistas foram aconselhados a permanecerem mais tempo no curso de formação.

16 A palavra extracomunitario designa aqueles que não pertenciam à Comunidade Comum Europeia, hoje chamada União Europeia. O termo, porém, ganhou conotação racista e depreciativa no uso popular, a ponto de ser proposta sua supressão no léxico da província de Savona em 2011 (GASPERETTI, 2011).

Ainda hoje o termo é usado tanto em Savona como em toda a Itália.

17 Dom Pedro Casaldáliga (Barcelona, Espanha, 16.02.1928), religioso espanhol radicado no Brasil, é também poeta e autor de diversas obras. Foi nomeado bispo de São Felix de Araguaia (Mato Grosso) em 1971, ocupando o cargo até 2005. Adepto da teologia da libertação, adotou como lema para sua atividade pastoral: "Nada possuir, nada carregar, nada pedir, nada calar e, sobretudo, nada matar." (SIMPÓSIO, 2009).

Desde novembro de 2012 vem sofrendo ameaças de morte devido à sua luta pela devolução das terras aos índios da etnia Xavante. Por cinco vezes, durante a ditadura militar, foi alvo de processos de expulsão do Brasil, tendo saído em sua defesa o arcebispo de São Paulo, Dom Paulo Evaristo Arns (REVISTA FÓRUM, 2013). 
Foi um coro de grande riqueza social que, em seus seis anos de vida, reuniu, no mesmo espaço, italianos, brasileiros, senegaleses, uma norte-americana, um suíço, peruanos, bolivianos, chilenos, um porto-riquenho, uma japonesa, uma croata, pessoas provenientes do Sri Lanka, de Madagascar e do Congo, todos com o mesmo objetivo: dar voz aos multicantos.

Devido às mudanças político-sociais ocorridas (aumento da xenofobia estimulado pelo governo e, por consequência, maior controle da polícia de imigração), esse coro não pôde prosseguir.

\section{Officina Barocca}

Nasceu em 1992 e, como o próprio nome diz, foi criado com o intuito de interpretar obras barrocas e a música colonial brasileira. É um coro montado com os participantes de outros grupos da ACC e seus ensaios existem em função dos concertos a preparar.

\section{Coro Curumim}

Nasceu em 1993, como coro infantil da ACC. É descrito em detalhes no item 1.2.1. deste capítulo.

Coro La Fucina Vocale ou Coro Didone (entre 1998 e 2000)

Esse coro feminino nasceu por acaso, em 1994. Abertas as inscrições para o coro escola Fabalalavos, apareceram 30 mulheres e dois homens. Um dos meus sonhos, que se revelou quando cantei pela primeira vez Vila Socó, meu Amor, de 
Gilberto Mendes ${ }^{18}$, no Coral do Museu Lasar Segall, estava se realizando: trabalhar com um grupo só de mulheres!

Se, hoje em dia, no séc. XXI, as mulheres ainda precisam lutar por igualdade de direitos, o que dizer dos anos noventa do século passado, em um país impregnado pelos ditames da Igreja Católica? Além de poder trabalhar com qualidades femininas, existia aquela sonoridade peculiar dos coros femininos, com poucos harmônicos, sons quase cristalinos, delicados, com possibilidades diferentes das dos coros mistos e infantis.

O coro foi montado e, após dois anos, começou a se apresentar em concertos. O nome La Fucina Vocale provém de obra homônima de Luigi Nono, mas foi mudado para Didone ${ }^{19}$, porque Fucina quer dizer fundição. Naquele momento, o coro se tornava performático e, portanto, o nome foi considerado inadequado, pois La Fucina Vocale poderia trazer uma conotação de falta de preparo vocal. Mais tarde, em 2002, por decisão de seus componentes, retomou seu nome original.

O grupo contava com entre 30 e 35 integrantes que cantavam a três ou quatro vozes, com regente e regente-assistente, com repertório multicultural, composto ou arranjado especialmente para vozes femininas.

\section{Quartetto Prometteo}

Depois de vários anos de formação musical de coralistas da ACC, em 1995 começam a despontar aqueles com qualidades para realizar concertos como solistas. $\mathrm{E}$ assim nasce o Quartetto Prometteo (nome dado em homenagem à obra "Prometeo" de Luigi Nono), criado para a peça de teatro baseada na obra "I ragionamenti" (Os

18 Gilberto Mendes (1922), compositor, jornalista, professor, escritor e figura importante no cenário da música contemporânea brasileira, é um querido com quem tive a honra de estudar no departamento de música da ECA-USP e o privilégio de ter muitas conversas amigas. Santista de coração, sua vasta obra musical é irreverente e criativa, onde encontramos um constante diálogo com o universo do cinema, sua grande paixão. Para conhecer melhor a obra dessa pessoa adorável, sugerimos o documentário Odisseia Musical de Gilberto Mendes.

19

O nome Didone é um jogo de palavras: Didone é, em italiano, Dido, a rainha de Cártago abandonada por Enéas, como descreve o poeta e escritor Virgilio em suas Eneidas; e di donne significa de mulheres. 
raciocínios, as reflexões) de Pietro Aretino ${ }^{20}$, na qual fizemos música renascentista ao vivo, por ocasião do Todi Festival di Teatro, em agosto de 1995. No ano seguinte, participávamos do concerto Buxtehude e Pasolini, com projeções de vídeo, coros e atores, apresentando cantatas de Dietrich Buxtehude ${ }^{21}$ dialogando com textos e trechos de filmes de Pier Paolo Pasolini.

\section{Terza Maggiore}

A SU, uma das sedes da ACC desde 1996, abriga uma das três entidades milanesas que, até 2003, promoviam cursos e atividades voltadas para a terceira idade. Em colaboração com esta entidade, a Humaniter, foi criado, em 1997, o Terza Maggiore, coro da terceira idade.

A idade média de seus componentes estava entre 60 e 70 anos, todos aposentados. Se, por um lado, dada a idade de seus integrantes, muitos não respondessem prontamente às exigências técnicas e tivessem dificuldades em reter informações, tornando o aprendizado lento, por outro, eram disponíveis e abertos às novas propostas. Muitas dessas pessoas estavam realizando um sonho, o de poder finalmente cantar, o que, por vários motivos, não puderam fazer na sua juventude. A consciência de ter pouco tempo a perder talvez fosse o motivo de percebermos que a vontade de participar era maior naquele grupo do que nos outros.

Em 2000 realizamos, com o Terza Maggiore, ajudado pelo Coro 1492 e um ator - Sergio Paladino - o concerto La Pazzia Senile (A Loucura Senil), com trechos dessa obra de Adriano Banchieri.

Durante a maior parte de seu percurso, esse coro foi dirigido por apenas um regente e seus componentes variaram entre 40 e 60 elementos.

${ }^{20}$ Pietro Aretino (Arezzo, 1492 - Veneza, 1556), escritor, poeta e dramaturgo italiano da renascença. De origem humilde, foi um crítico mordaz dos costumes de sua época, temido e respeitado pelos homens de poder, artistas e religiosos, tornando-se conhecido por essas críticas e por sua obra erótica.

${ }^{21}$ Dietrich Buxtehude (Bad Oldesloe, 1637- Lübeck, 1707), compositor e organista teuto-dinamarquês do período barroco. Fizemos diversas cantatas desse compositor, como Membra Jesu Nostri, Ich habe Lust abzucheiden, Jesu meiner Freud und Lust. 


\section{Coro Bat Kol}

No ano de 1999, quando nasceu esse coro, inicia-se a colaboração entre a ACC e o Coro Col Há Kolot, que mais tarde se torna Bat Kol (literalmente "filha da voz", expressão usada metaforicamente para definir a "Voz Celestial" em hebraico).

É um grupo interessado em difundir a música hebraica entendida em sua concepção mais ampla, com particular referência às diversas expressões da música da diáspora de tradição sefardita e asquenazita ${ }^{22}$.

Seus principais concertos e atividades artísticas, desenvolvidos em parceria com a ACC, foram a passeata Mille Voci per la Pace em 1999, finalizada com um concerto na Basílica de Milão; realização da obra coral sinfônica Anna Frank, do compositor italiano Leopoldo Gamberini ${ }^{23}$, em março de 2000, na Sala Verdi do Conservatorio Giuseppe Verdi de Milão; realização de dois festivais europeus de coros hebraicos em Milão; e participação no concerto da Fantasia Coral de Beethoven, regida pelo Mํo Stefano Lucarelli e com Bruno Canino como pianista solista.

\section{Coro del Liceo}

Durou apenas dois anos, entre 2000 e 2001, e foi uma preparação ao canto coral para alunos do Liceo Artistico Leone XIII, em Milão. Na Itália, o "liceo" corresponde mais ou menos ao nosso atual ensino médio.

22 Sefarditas (sefaraditas ou sefaradim) e asquenazitas (ashkenazim) são dois grandes ramos derivados de uma base religiosa comum, a cultura judaica, que se desenvolveu na Europa durante a Idade Média. Os sefarditas se desenvolveram na península ibérica, enquanto os asquenazitas, radicados na França e Alemanha, se desenvolveram pela Europa central e oriental. Hélio Cordeiro classifica os judeus, etnicamente, do seguinte modo: asquenazitas - maior grupo de judeus da Europa centrooriental e descendente, que fala um dialeto chamado de í́diche; sefaraditas - judeus da Península Ibérica que utilizam o dialeto ladino. Presentes em Portugal e Espanha, os sefaraditas constituem a maioria dos judeus que vieram para o Brasil durante o período colonial (CORDEIRO, 2002 apud BARBOSA, 2006).

${ }^{23}$ Leopoldo Gamberini (Como, 1922), compositor, musicólogo, maestro de coro e de orquestra italiano. 
A introdução ao canto coral foi feita com adolescentes entre dezesseis e dezoito anos, organizada por uma equipe técnica constituída por dois regentes e uma professora de técnica vocal.

O repertório trabalhado foi de canções a quatro vozes com pequena tessitura nas vozes masculinas, de acordo com as possibilidades vocais dos integrantes.

\subsubsection{Grupos de Apoio às Atividades Corais}

\section{Grupo de estudos}

O grupo de estudos era formado por membros dos vários grupos corais que se reuniam para programar as atividades culturais da ACC e pesquisar o material teórico que servia de suporte para essas atividades.

Em 1994, esse grupo organizou dois ciclos de conferências sobre a música brasileira no Consulado Brasileiro em Milão, e, em 1995, organizou a manifestação Quattro giorni nei dintorni di Bahia (Quatro dias nas vizinhanças da Bahia), nos espaços da Basilica di San Lorenzo alle Colonne.

Em 1996 deu suporte teórico ao espetáculo Buxtehude e Pasolini (descrito no item 1.1.1) e, em 2003, suas pesquisas serviram para a montagem do espetáculo Una Donna Abitata, realizado pelo Ensemble Foresta ${ }^{24}$ e o coro La Fucina Vocale.

24 Ensemble Foresta era o quarteto feminino da ACC, composto por piano, harpa, mezzo-soprano e soprano. Nasceu em 2003 para o espetáculo citado. Seu nome se inspira em obra de Luigi Nono. 


\section{La fabbrica del suono}

Nasce em 1989, constituído por um grupo de jovens compositores da ACC. Era um laboratório de composição de música contemporânea, pesquisas sonoras ligadas ao canto coral e edição de partituras. O grupo também se ocupava de arranjos para música coral, algumas usadas nos coros da $\mathrm{ACC}^{25}$.

\subsection{Projetos Infantis Curumim (PIC)}

"Curumim", segundo o dicionário Houaiss da língua portuguesa, quer dizer "rapaz jovem; garoto; menino" em língua tupi. Aqui no Brasil, esse é um nome muito usado para tudo o que se refira à infância, como escolas, projetos sociais e educativos, animação infantil, clínica médica etc. ${ }^{26}$ Mas, o que é comum para nós brasileiros, é estranho e curioso para pessoas de língua italiana e nossa intenção era justamente essa: despertar a curiosidade sobre a vastidão da cultura brasileira por meio de um nome indígena.

O primeiro grupo coral do PIC inicia suas atividades no dia 4 de outubro de 1993, em colaboração com o $\operatorname{COE}^{27}$. Com sede na Basilica di San Lorenzo alle

25 A mestranda participou desse grupo, produzindo arranjos corais para a ACC e também editando algumas partituras.

26 Como dissemos anteriormente, foi criado para essa dissertação o nome Projetos Infantis Curumim, que engloba atividades socioartísticas e culturais desenvolvidas na Itália, entre 1993 e 2003, onde a mestranda tomou parte ativa como colaboradora regente e/ou coordenadora. As atividades desenvolvidas no PIC, na Itália, não possuem nenhum vínculo com o Projeto Curumim do SESC (criado em 1987 em São Paulo), ou com o Projeto Curumim de Atibaia (criado em 1999), tampouco foram inspiradas nestes, mas estão em sintonia com eles no que diz respeito a intenções artísticas, culturais e de formação social.

${ }^{27}$ Centro Orientamento Educativo ( $\left.\mathrm{COE}\right)$, instituição de apoio educacional à população do terceiro mundo, fundada pelos jesuítas. 
Colonne ${ }^{28}$, funcionou como um curso de preparação ao canto coral, com encontros semanais de uma hora, durante o ano letivo $1993 / 1994^{29}$.

Em junho de 1995, o Coro Curumim retoma suas atividades, em colaboração com a Scuola di Musica II Classico ${ }^{30}$. Essa colaboração iniciou com duas semanas de atividades vocais intensivas em junho, em dez encontros, no Centro Sociale Ponte delle Gabelle $^{31}$, partindo para atividade semanal em outubro do mesmo ano, com sede na própria escola de música. As crianças que participaram desse momento do Curumim estudavam outros instrumentos na escola, além de participar do coro.

Em 20 de novembro de 1996, o coro infantil inicia a colaboração com a SU, lá permanecendo até junho de 2002.

No ano letivo de 2002/2003, o coro transfere-se para as salas da Libreria Claudiana $^{32}$ e também cria um novo grupo de preparação ao canto coral infantil, como curso de extensão, na escola pública de ensino fundamental Scuola di Via Guicciardi ${ }^{33}$.

A partir de junho de 1995, a mestranda torna-se a coordenadora do PIC e regente responsável pelo Coro Curumim da ACC, com assistência de Claudia Regina Costa e direção artística de Martinho Lutero.

Além dos coros infantis, foram realizadas outras atividades que envolveram crianças, como espetáculos para teatro com música coral, concertos com coros infantojuvenis, um laboratório musical para preparação de um espetáculo e os laboratórios musicais das férias. Essas atividades, além de seu valor artístico-cultural intrínseco, serviram para atrair crianças para os Coros Curumins, que aconteciam de maneira estável durante o ano letivo.

O Coro Infantil do ano 2000, apto a gravar em estúdio a música Festa! - tema da Festa Internazionale della Musica na Itália e vinheta do evento em propagandas na

${ }^{28}$ Basilica di San Lorenzo alle Colonne é uma importante catedral milanesa onde realizamos diversos concertos corais e outras atividades culturais, tanto nos seus espaços externos quanto dentro da própria igreja.

${ }^{29} \mathrm{Na}$ Itália, assim como em outros países do hemisfério norte, o ano letivo começa em setembro e termina em junho.

30 Scuola di Musica il Classico é uma escola particular de música para crianças, situada em Milão.

31 Centro Sociale Ponte delle Gabelle é um centro social da prefeitura de Milão.

32 Libreria Claudiana é uma livraria associada à Igreja Protestante, que aluga salas para atividades socioculturais.

33 Scuola di Via Guicciardi é uma escola da periferia da rede pública milanesa, onde $30 \%$ das crianças eram extracomunitárias. 
televisão e rádio - e a se apresentar em teatros e igrejas milaneses, foi fruto de um processo lento e gradativo de construção.

A partir de 1997, o número de crianças que procuravam o coro infantil aumentou e assim foi possível a criação de mais um grupo de preparação ao canto coral. Depois de dois anos, apareciam cada vez mais crianças, o que possibilitou a criação de um terceiro grupo estável. Assim, entre 1999 e 2001, o Coro Curumim contava com um grupo de iniciantes, um de intermediários e um de avançados.

Esses grupos, ao menos duas vezes por ano, se encontravam para apresentações conjuntas, onde todos os pequenos coralistas cantavam o que estivesse de acordo com seu desenvolvimento musical do momento. Na maioria das vezes, essas apresentações eram feitas em conjunto com músicos profissionais (instrumentistas, cantores ou coros de adultos da ACC, e/ou músicos convidados), somando qualidades artísticas para a apresentação e crescimento artístico, social e musical para as crianças do coro. As apresentações eram prazerosas não apenas para os ouvidos "comprometidos" dos familiares, mas para o público em geral, contribuindo para a formação de um sentido estético musical nas crianças.

Os curumins foram agrupados principalmente segundo suas habilidades musicais, tais como percepção auditiva e emissão vocal, noções dos parâmetros sonoros, grau de afinidade com a partitura e memória musical, possibilitando a escolha de um repertório e atividades de suporte para a realização do mesmo, pertinentes e diferenciados de acordo com os momentos específicos de cada grupo ${ }^{34}$.

Os grupos se constituíram de forma heterogênea quanto à idade e escolaridade. A experiência pessoal demonstrou que o desenvolvimento musical individual é diversificado, próprio de cada criança e independe de idade e nível escolar, permitindo o agrupamento de crianças entre quatro e onze anos ${ }^{35}$ que apresentavam

34 O critério foi agrupar as crianças de acordo com suas qualidades musicais principalmente depois de 1997, quando começamos a ter grande demanda e pudemos realizar mais de um grupo no mesmo período. Durante toda a história do Curumim, nunca recusamos a entrada de uma criança, fossem quais fossem suas habilidades musicais.

35 A maior parte das publicidades para o Coro Curumim naquela época chamavam crianças de 4 a 11 anos, mas geralmente apareciam crianças entre seis e dez anos e, quando chegavam crianças com idade maior ou menor que a pré-estabelecida, eram aceitas para experimentar os grupos. No caso das crianças pequenas, geralmente eram os irmãozinhos menores que, quando se adaptavam às regras de comportamentos que o trabalho coral exige, permaneciam; quanto às crianças mais velhas, 
qualidades musicais semelhantes e de mesmo nível. Levando em consideração as exigências pertinentes aos diferentes estágios psicológicos de crescimento pessoal num grupo de idades tão heterogêneas, foi programada uma dinâmica de grupo que promovesse situações, além daquelas surgidas no dia a dia, nas quais as crianças mais velhas tivessem que ajudar as mais novas, valorizando suas capacidades. Aos mais velhos eram pedidos a organização e a distribuição das partituras, a coordenação da sistematização do ambiente de ensaios e o apoio aos mais novos, ajudando na compreensão dos conteúdos. Criou-se, assim, um ambiente de respeito mútuo, em que as potencialidades individuais foram valorizadas para atingir o objetivo único: cantar em coro.

Essas crianças, com raras exceções, tiveram seu primeiro contato com o canto coral no Curumim. Assim sendo, muitas precisavam ser despertadas para a descoberta de suas potencialidades vocais.

O Coro Curumim não teve como objetivo principal a educação musical, mas é inevitável o casamento entre o pedagógico e o artístico quando se fala em canto coral com amadores, principalmente ali, onde havia a preocupação com o crescimento musical das crianças. As atividades oferecidas nos ensaios, que serviram como suporte para atingir as exigências que a prática musical coral infantil com repertório multicultural e voltada à performance requer, foram elaboradas usando uma linguagem infantil por excelência: o lúdico, no sentido de usar jogos, contos e encenações, com finalidades musicais e também de propiciar um ambiente prazeroso, criando os pressupostos afetivos para a aprendizagem do repertório e habilidades técnicas necessárias ao canto coral.

Nesses dez anos, além da variação das crianças, também tivemos variações na equipe de trabalho, mantendo constantes apenas a minha presença e a do maestro Martinho Lutero. Vale ressaltar que as qualidades individuais, tanto das crianças quanto dos profissionais, trouxeram diferenças nas diversas formações, e cabe aqui descrever as contribuições mais significativas de cada um dos integrantes da equipe e das características gerais dei bambini.

eram aquelas que vinham cantando conosco há vários anos e queriam continuar no Curumim apesar de terem extrapolado a idade limite. 
Com exceção do espetáculo Vamos Brincar, desenvolvido em Crotona, Calábria, em 1993, todos os grupos e projetos do PIC estavam sediados em Milão ou em sua periferia.

\section{Milão do PIC}

O relato a seguir é um olhar sobre Milão nos anos em que os trabalhos do PIC foram realizados, na intenção de contextualizar 0 universo das pessoas que participaram dos grupos infantis, de acordo com memória pessoal.

Naqueles anos a cidade contava com algo em torno de $1.300 .000^{36}$ moradores e quase três milhões de frequentadores assíduos: ou seja, muitos trabalhadores - a mestranda inclusive - moravam fora daquela cidade. Aquela Milão muito se assemelhava guardadas as devidas proporções, a São Paulo: uma intensa atividade artístico-cultural, uma população apressada e estressada, o trânsito caótico, o céu constantemente nublado pela poluição (apesar de ser menor do que a de São Paulo), uma cidade de negócios - degli affari - que oferecia trabalho, de maneira oficial e extraoficial, a muitos migrantes e imigrantes. Cidade de cores opacas - devido não apenas ao céu geralmente encoberto, mas também às pinturas gastas das construções antigas, muitas delas medievais -, com poucas áreas verdes, e muito cimento e concreto em prédios que não superavam cinco andares (com exceção de uma dezena de grattacieli - arranha-céus), às vezes timidamente coloridos. Arquitetura impregnada de histórias: o Duomo de Milão com sua madoninna d'oro, inspiradora dos cantautori meneghin $^{37}$, brilhando solitária no topo da catedral, e os vitrais de Leonardo Da Vinci que emocionam sem a gente saber por que, ao lado daqueles que tentaram imitá-los, em vão, para reconstituir parte destruída na Segunda Guerra; a Galeria Vittorio Emanuelle II, com suas lojas de grife, luxuosos caffé e restaurantes - e um horrível Mac

${ }^{36} \mathrm{Em} \mathrm{1991,} \mathrm{Milão} \mathrm{contava} \mathrm{com} \mathrm{1.369.295} \mathrm{habitantes,} \mathrm{diminuindo} \mathrm{para} \mathrm{1.242.123} \mathrm{em} \mathrm{2011.} \mathrm{(TUTTITALIA.}$ IT, 2013).

37 Cantautori meneghin pode ser traduzido como músicos milaneses. Cantautori são músicos que compõem e cantam suas próprias canções; Meneghin (ou meneghino) é o dialeto milanês. Essa palavra também serve como adjetivo para tudo que pertence à Milão. 
Donald's! - que povoam seu salão octogonal e os dois braços que ligam as praças do Duomo à do Teatro alla Scala, sob o teto de vidro e ferro, com chão de mosaicos, onde a figura do pobre touro, que representa o brasão da cidade Torino, é pisoteada em suas partes por turistas desejosos de retornar à cidade; a igreja Santa Maria Presso di San Satiro, onde conheci meu primeiro trompe l'oeilis; o famoso Teatro alla Scala; o Conservatorio Giuseppe Verdi (que tomou emprestado o nome do compositor recusado como aluno), onde trabalhei no coro dos cursos noturnos, o $\mathrm{CPSM}^{39}$, cantei com o Coro Cantosospeso em várias ocasiões e assistia a ensaios de orquestras em suas salas de concerto, inclusive um ensaio em que o maestro brasileiro Isaac Karabitchewski foi aplaudido de pé pela extinta orquestra da RAl; o Castello Sforzesco, que teve sua velha praça de armas transformada, no restauro do início do século XX, no Parco del Sempione, uma das poucas áreas verdes da cidade; as deliciosas bibliotecas do Conservatorio Giuseppe Verdi e da Sormani, as duas com o mesmo odor peculiar de coisa antiga que me lembrava o cheiro da escola francesa, o Liceu Pasteur, uma das referências europeias pessoais. Pelas ruas planas, organizadas em artérias que se ligam a grandes círculos, passeavam, além de automóveis novos e bicicletas, 'tram' (bonde) e 'autobus' (ônibus) laranjas, assim como pessoas brancas, geralmente bem vestidas que, ao longo dos anos, foram se colorindo e se diversificando devido à intensificação da imigração.

Ainda em 2003, a diferença relativa de salários da média dos trabalhadores formais era pequena, em torno de três vezes ${ }^{40}$, diminuindo as diferenças entre classes sociais. Ao chegar à Itália, nos anos noventa, acostumada com as diferenças salariais em nosso país, lembro-me da surpresa ao saber que um faxineiro que trabalhava in nero (de maneira informal), ganhava algo em torno de 800.000 liras, enquanto um

38 Trompe l'oil é uma técnica das artes plásticas que, com truques de perspectiva, cria uma ilusão óptica que mostra objetos ou formas que não existem realmente.

39 CPSM - Corsi Populare Serali Musicale (cursos musicais populares noturnos). Durante o dia, o conservatório abrigava os cursos diurnos de formação profissional para crianças e adultos, e, à noite, essas salas eram ocupadas por cursos musicais (coro, canto e outros instrumentos), voltados aos amadores.

40 Segundo a informante Tereza Isenburg, professora titular da cátedra de geografia da Universidade de Milão, o índice oficial das diferenças salariais na Itália, estimado pela Eurostat (Gabinete de Estatísticas da União Europeia), em 2002, era de 2,7 vezes. Em nossos dias, a disparidade entre salários de trabalhadores vem aumentando na Itália: a retribuição dos trabalhadores mais bem pagos cresceu em relação aos mais mal retribuídos, fazendo, assim, aumentar a disparidade entre aqueles que ganham mais e os que ganham menos. 
médico chefe do setor de imunologia do principal hospital de Milão ganhava 5.000.000 liras.

Um amigo brasileiro dizia que Fellini fez só deixar a câmera aberta e registrar o povo italiano. Essa impressão é verdadeira para turistas que chegam no verão e encontram pessoas falantes, que, no meio de uma discussão ferrenha, entre gritos, quando tudo indica que a história vai acabar mal, mudam a rota com piadas e começam a se abraçar da mesma maneira escandalosa. Em geral, é um povo que gosta de se expressar com sons e gestos exagerados, como vemos nos filmes, mas o indivíduo, o nosso amigo, é bem mais rico e complexo do que estereótipos.

Nesses anos, fiz muitos amigos italianos, pessoas generosas, amorosas, afetivas, que me ajudaram a suportar o contato diário e superficial com o garçom malhumorado do café, que nem respondia ao bom dia, ou o prepotente bibliotecário. Só vivi a frieza e a distância "comum" do povo milanês nas relações superficiais, no contato com o outro desconhecido e que se mantinha como tal; os amigos italianos, companheiros de cantos e distensões, com quem realmente vivi nesses anos, estão longe de qualquer catalogação generalizada: são únicos e especiais, assim como o são as crianças do Curumim.

A maior parte dos curumins passava o dia inteiro na escola pública, até as $16 \mathrm{~h} 30^{41}$, e depois vinha diretamente para os ensaios, de carro, em meio de transportes, a pé, de motorista particular...

Essas crianças eram filhas de trabalhadores: médicos, advogados, artistas, empresários, faxineiros, publicitários, diretores, empregados de corporações etc., com formação universitária ou técnica, alfabetizados, italianos de Milão ou de outras regiões da Itália, e também estrangeiros. Algumas dessas crianças entraram por serem filhos dos nossos coralistas da ACC, assim como alguns pais de "curumins" se tornaram cantores nos nossos coros adultos após a entrada de suas crianças no coro infantil; outras chegaram por causa da publicidade, outras por meio dos laboratórios infantis, outras por terem assistido algum concerto do ACC etc.

41 São as chamadas escolas "a tempo pieno" (período integral), ainda vigentes na Itália. Na época, o ensino era obrigatório para crianças entre seis e treze anos, em salas com não mais do que 25 alunos, e as escolas públicas eram a regra, mesmo para aqueles que pudessem pagar escolas particulares, devido à qualidade do ensino. 
Nossas crianças eram como são as crianças de qualquer lugar do mundo! Curiosas, inquietas, propositivas, participativas, manhosas, carinhosas, briguentas, concentradas, introspectivas, reativas, solidárias, alegres, mal-humoradas... Nosso trabalho era aproveitar e realçar qualidades dos pequenos no sentido de criar um ambiente harmonioso, em que pudéssemos "jogar" canto coral, mostrando que aquele jogo era divertido, pelo qual valia a pena seguir as regras e deixar de fora as qualidades que impediam a brincadeira.

Assim como os amigos italianos, não há como generalizar as crianças do Curumim, a não ser pelo fato de cada um, com suas especificidades, encontrar-se vivo em meu coração.

\subsubsection{Coro Curumim entre 1993 e 2003}

\section{Preparação ao canto coral, no ano letivo de 1993/1994.}

Na primeira formação do coro infantil, em 1993, a mestranda foi assistente de Susana Alvear e de Martinho Lutero, o regente titular. Susana Alvear, chilena exilada na Itália, era dançarina, percussionista, professora de musicalização infantil e cantora. Estudou com Martinho Lutero e formou-se no Centro per l'Educazione Musicale di Base (C.E.M.B.) com o professor Giordano Bianchi ${ }^{42}$. Sua experiência com o método linguístico musical de Bianchi, criado para ser usado nas escolas italianas, trouxe jogos com o intuito de ensinar noções rítmicas a partir de palavras do universo infantil (nome de animais, flores, brinquedos, seus próprios nomes etc.), usando sílabas tônicas para definir os compassos, (por exemplo: Gat-to - compasso binário; Vir-gi-lio - compasso

\footnotetext{
42 Giordano Bianchi (1920 - 2009), professor de escola fundamental, idealizou a metodologia linguísticomusical que desemboca no método interdisciplinar de base. Publicitário e formador de fama internacional, foi idealizador e precioso colaborador junto a Carlo Delfrati da SIEM (Società Italiana per l'Educazione Musicale ), fundada em 1969. Em 1977, fundou, em Milão, o CEMB (Centro Educazione Musicale di Base), que forma professores de música e animadores musicais de crianças.
} 


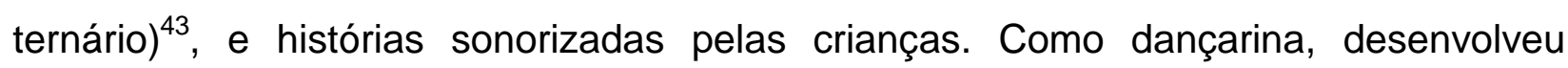
atividades lúdicas ligadas às expressões corporais; como chilena, ensinou uma linda canção em espanhol, Palomita Blanca ${ }^{44}$, de que fizemos uma versão em italiano e também em português, para cantarmos em três línguas.

Iniciamos o trabalho com poucas crianças e, ao final do ano, contávamos com quase 20 cantorezinhos entre quatro e dez anos, em grande parte imigrantes ou filhos de imigrantes. O propósito deste primeiro coro era, além do óbvio - a formação de um grupo coral infantil - o de integrar crianças italianas e 'extracomunitárias', seguindo o exemplo do Coro Vù Cantà (descrito neste capítulo no item 1.1.1.) Dentre essas crianças estava Virgilio, meu enteado, na época com quatro anos, que permaneceu até a última formação do Curumim.

O trabalho direto com o grupo de crianças - um dia por semana, duas horas de ensaio - era realizado por Susana e pela mestranda ${ }^{45}$, sem auxílio de instrumentos harmônicos, apenas com o apoio de instrumentos de percussão e o diapasão. Tínhamos também reuniões semanais com o regente titular, quando trocávamos opiniões sobre o andamento dos ensaios: estratégias e caminhos usados na formação do coro infantil, especificidades das crianças (dificuldades, habilidades, comportamentos etc.), e conversávamos sobre repertórios adequados.

No final de 1993, as crianças cantaram três músicas no concerto Boas Festas (ver ANEXO A): Nikaiedo (canção tradicional moçambicana em língua chuabo ${ }^{46}$ ), Adeste Fidelis (canção tradicional natalina) e Minha Canção ${ }^{47}$ (de Enriquez, Bardotti e Chico Buarque, baseado no arranjo de Ana Yara Campos ${ }^{48}$ ), com todos os coros. Em maio de 1994, cantamos N'Kosi Sikeleli Africa (canção sul-africana de E. Sontonga e S.

${ }^{43}$ Exemplos dessas atividades se encontram em BIANCHI; BAGOZZI, 1984, p.120.

44 O nome original da canção tradicional argentina é Palomita Blanca, mas, por cantarmos em três línguas, em alguns concertos consta como Pomba Branca ou Colombina Bianca.

${ }^{45}$ Excetuando os ensaios gerais dos concertos e algumas "visitas" aos curumins, em que o maestro Martinho Lutero também trabalhava diretamente com as crianças.

${ }^{46}$ Chuabo é uma língua banto, da grande família Níger-Congo e do grupo das línguas Emakhuwa. Sete por cento da população moçambicana tem essa língua como materna.

$47 \mathrm{Em}$ alguns concertos, foi usado o nome Dorme a Cidade para Minha Canção. Não me lembro do motivo, mas acredito que ganhou esse "apelido" por serem as primeiras palavras da canção.

48 Ana Yara Campos, jornalista e maestrina brasileira, e uma grande amiga, que fez com que me apaixonasse pela técnica vocal. Nos anos oitenta e noventa regeu o coro Libercanto de São José dos Campos e continua ativa na profissão como regente e professora de cursos de canto coral por todo o Brasil. 
Majombozi), analisada no segundo capítulo, no item 2.1.5.; e Nikaiedo e Canção Amiga (de Milton Nascimento, com palavras de Carlos Drummond de Andrade, no arranjo coral do Mํ Samuel Kerr) no concerto Saluba, com os coros da ACC e músicos brasileiros e africanos (ver ANEXO B). Além dessas canções, ensaiamos Palomita Blanca, Milho Verde (tradicional portuguesa), Canto Txucarramae (do arranjo coral Três canções Kraò do maestro carioca Marcos Leite) e Su, su, su che 'l giorno è fore (canção a três vozes de Claudio Monteverdi). Todas as músicas eram cantadas em uníssono ou a duas vozes, mesmo a de Monteverdi.

Essa foi a primeira experiência da mestranda com grupo de crianças - até então só havia dado aulas de piano para crianças individualmente e só tinha experiência com grupos de adultos - e aprendemos muito assistindo, escutando os regentes e arriscando atividades lúdicas musicais que nem sempre "davam certo", mas eram redirecionadas pelos veteranos atentos. Suprindo a falta de experiência com grupos infantis, a mestranda tinha a seu favor um querer bem autêntico pelas crianças, a paixão pela música, anos de estudos e práticas musicais, e um lado menina que sempre a estimulou a viver brincando. Faltava paciência e melhor compreensão das necessidades infantis, mas, aos poucos, aprendemos com as crianças e equipes de trabalho e, principalmente, com a amiga e assistente Claudia Regina Costa.

\section{Parceria com a Scuola di Musica II Classico no ano letivo de 1995/1996}

Como dissemos anteriormente, a atividade introdutória à formação desse novo grupo coral infantil deu-se em dez encontros durante duas semanas de atividades vocais com crianças, comigo e com o Lutero, em um centro social da prefeitura de Milão (ver ANEXO C).

A partir de outubro do mesmo ano, entra na equipe Claudia Regina Costa, pedagoga formada pela FE-USP, cantora do Coro Luther King desde seus dezesseis anos, dona de uma voz encantadora, hábil no trato com as crianças, paciente, 
observadora, atenta às necessidades extras musicais dos pequenos, extremamente organizada e amorosa. Claudia trabalhou como assistente até 2003, quando voltei ao Brasil, e depois continuou regendo grupos infantis por alguns anos, sendo, até hoje, assistente do diretor artístico da ACC. Foi minha aluna de teoria musical por um ano e depois continuamos a trocar figurinhas de maneira informal: enquanto eu the passava noções musicais, Claudia me oferecia sua visão pedagógica. Mas não foram apenas essas as trocas... O trabalho com os coros infantis floresceu, dada a perfeita sintonia entre amigas e companheiras de jornada musical. Nosso relacionamento de respeito, carinho e cumplicidade influenciou, de maneira positiva, a criação de grupos harmoniosos; nossa paixão pela música, principalmente pela música coral, incentivava a criançada a cantar. Encontrávamo-nos quase todos os dias, pois, além do coro infantil, cantávamos e trabalhávamos nos diversos coros da ACC e passávamos juntas também nosso tempo livre, muitas vezes falando, escutando e fazendo música...

A partir desse ano, Lutero deixou em nossas mãos o PIC, permanecendo como diretor artístico dos corais infantis, e fazíamos reuniões informais, já que nós três nos encontrávamos quase todos os dias. A partir de então, a responsabilidade oficial do PIC ficou com a mestranda, na função de coordenadora das atividades infantis da ACC, contando com o apoio de Claudia como assistente, de Lutero como diretor artístico e do suporte da ACC.

O grupo de aproximadamente dez crianças era composto, em sua maioria, por pequenos instrumentistas da escola de música /l Classico, entre quatro e oito anos. Do primeiro grupo coral, apenas uma criança participou desse novo grupo. Para os alunos da escola, era uma disciplina opcional. Havia na sala um piano de meia cauda, o que motivou diversas atividades, excetuando o ensino e repasse das melodias ${ }^{49}$. Usávamos esse instrumento apenas para acompanhar harmonicamente as canções e eventuais jogos.

No final do ano letivo, fizemos duas apresentações do coro infantil: no espetáculo Tele e Visione (ver ANEXO D), peça teatral da escola, realizada em Milão, na Sala Orizzonte, no dia 26 de maio de 1996, quando cantamos sozinhos Minha

${ }^{49}$ Transmitir as melodias através da voz, ao invés de usar outro instrumento, foi e é uma opção da mestranda, porque a voz é seu instrumento musical principal e, por consequência, o meio pelo qual transmite com maior fidelidade nuances musicais. 
Canção, N'Kosi Sikeleli Africa e Palomita Blanca; e no espetáculo músico-teatral Girotondo, (ver ANEXO E), na sala de concertos da Basílica di San Lorenzo alle Colonne, em Milão, no dia 7 de junho de 1996, quando cantamos II Treno (canção tradicional japonesa) e N'Kosi Sikeleli Africa, junto com os coros adultos da ACC. Para essas apresentações, organizamos três ensaios extras (ver ANEXO F). Durante o ano, nosso repertório constou, além das apresentadas no espetáculo, de diversas canções em uníssono ou a duas vozes já realizadas pelo primeiro coro: Nikaiedo, Canto Txucarramae, Su, su, su che 'l Giorno è Fore, Milho Verde; e as novas Os Brinquedos ${ }^{50}$ (canção tradicional moçambicana) e Peixinhos do Mar (canção tradicional brasileira).

A parceria com essa escola terminou devido à nossa recusa em dar notas de zero a dez às crianças e, em vez disso, escrevermos um texto sobre as qualidades e habilidades musicais, e sugestões de crescimento para cada uma delas ${ }^{51}$. Fomos demitidas.

\section{Relato sobre a turnê a Burkina Faso e início da parceria com a Società Umanitaria entre 1997 a junho de 2002}

Havíamos acabado de chegar de uma turnê a Burkina Faso ${ }^{52}$, antigamente chamado de Alta Volta, país africano cujo nome quer dizer "pátria de homens íntegros". Além de muitos integrantes dos diversos coros da ACC, participaram coralistas do Coro

50 Assim como Minha Canção, essa peça ganhou em nosso coro o apelido Vamos Brincar.

51 Margaret Amaral de Andrade reporta a indagação pertinente ao nosso tema feita pelo educador musical Swanwick: "Se pedirmos às pessoas que avaliem uma execução musical ou composição simplesmente utilizando uma escala de um a oito, sem anexar uma descrição qualitativa, elas poderão fazer isso com segurança e assim haver consistência entre os jurados?" Swanwick (apud ANDRADE, 2003, p. 77), considera a possibilidade de uma avaliação quantitativa através de uma justificativa qualitativa anexada. Na época, a mestranda desconsiderava a possibilidade de uma avaliação quantitativa, optando pelos comentários sobre aspectos gerais da criança, como suas qualidades e habilidades musicais, e sugestões para o desenvolvimento das mesmas, de maneira a estimulá-las, mas sem deixar números. Hoje percebo que poderia ter anexado um número ao lado das reflexões, mas, na época, ainda era inexperiente e inflexível.

52 Figurativamente, "Burkina" pode ser traduzido por "homens íntegros", da língua More, e "Faso" significa "pátria" em Dioula. A língua oficial é o francês, mas grande parte da população fala o Dioula ou More. 
Luther King de São Paulo e alguns integrantes da Associazione Interculturale Koron Tlè, criada pela atriz e diretora de teatro Serena Sartori ${ }^{53}$.

Em julho de 2006, ao chegar a Burkina Faso, fomos abraçados pelo calor que sobe da terra vermelha dos griots ${ }^{54}$, recebidos por Dany Kouyaté, dono da empresa cinematográfica Sahelis ${ }^{55}$. Burkina Faso, à época, ocupava o $5^{\circ}$ posto dos países mais pobres do mundo e vivia de ajuda internacional, desprovido de um projeto interno governativo de desenvolvimento. Apesar da pobreza, apresentava projetos culturais interessantes, como o FESPACO (Festival Pan-africano de Cinema Bienal), com sede em Ouagadougou, capital do país, a mostra de produções culturais de Burkina Faso e países vizinhos, como Togo e Costa do Marfim, e a semana de cultura na cidade de Bobo Diolassou (MAGRO, 1997, p. 7 e 8).

É impossível descrever em poucas linhas o que vivenciamos nesses quinze dias de convivência e trocas culturais com a população burkinabê, pois cada peça do mosaico que a memória traz à tona seria digna de maiores detalhes: os homens bonitos, negros, altos, esguios, que capinavam com a coluna reta; a beleza das mulheres trabalhadoras, seus modos de rainha, com suas roupas coloridas e cabelos bem cuidados, fabricantes de um dos principais produtos da economia local, a manteiga de karité; os imponentes e acolhedores baobás; o olhar atento das crianças de Sindou ${ }^{56}$ ao ouvir Waldesnacht de Brahms ${ }^{57}$; os Picos Sacros de Sindou, mágicos, com uma

53 Serena Sartori é atriz e diretora de teatro. Entre 1985 e 1995 torna-se diretora artística e diretora de espetáculos do II Teatro del Sole. Em 1981 funda, com outros, a Scuola di Formazione Attorale em Milão, que prossegue até 2003 como Scuola di Formazione Attorale Koron Tlè. Desde 1990 inicia uma intensa atividade paralela como diretora na Alemanha, Suíça e Áustria, e vários projetos artísticos na África e na Europa.

Realizamos diversos projetos artísticos com Serena Sartori no período em que dirigia II Teatro del Sole, sendo o mais significativo deles o espetáculo músico teatral Oltremare, realizado com coro misto de 40 pessoas e atores, que mostrava a imigração italiana na América, uma maneira de alertar para o xenofobismo crescente naqueles anos 90, na Itália, mostrando artisticamente o quanto a luta dos imigrantes italianos do começo do século XX se parecia com os imigrantes de países pobres que se mudavam para a Itália.

${ }^{54}$ O Griot é uma espécie de enciclopédia ambulante, um contador de histórias que, acompanhado de um instrumento musical, preserva a cultura de seu povo; é também um líder da comunidade, a quem as pessoas ouvem e com quem se aconselham. A família Kouyaté é tradicionalmente de griots. Dany, que nos recebeu, é filho do grande griot Sotigi Kouyaté, conhecido internacionalmente após sua atuação no filme Mahabaratha de Peter Brook.

55 Para saborear um pouco de Burkina Faso, sugiro o filme Keita! O legado do Griot, dirigido por Dani Kouyatè e produzido por sua empresa cinematográfica Sahèlis, em 1994.

${ }^{56}$ Cidade de Burkina Faso.

57 Waldesnacht é a terceira canção do ciclo Sieben Lieder, op. 62, uma peça coral a quatro vozes mistas do compositor alemão Johannes Brahms (1833 - 1897). Fizemos um concerto para a tribo de 
acústica maravilhosa e um ar fresco que acariciava nossos rostos ${ }^{58}$; os coros que dançavam ao cantar com aquela emissão vocal aberta, clara, forte, característica dos povos que passam muito tempo ao ar livre ${ }^{59}$; a afinação dos grupos corais e tradicionais, tão diferentes do nosso sistema temperado; o francês falado com o "r" rolado $^{60}$; as motocas que singravam a terra vermelha levantando a poeira que tingia nossas roupas; a grande festa em torno da mangueira, em que assistimos a danças com máscaras acompanhadas pelo conjunto de balafons ${ }^{61}$, e até fomos convidados a dançar também no círculo; o mercado com seus cheiros, sabores e falatórios; o cheiro de manga pelas ruas das cidades; o guisado de morcego e as larvas fritas de cupim que nos serviram de refeição; e tantas, tantas experiências intensas...

Apesar de nenhuma canção burkinabê fazer parte do repertório do PIC, a importância do relato da turnê aqui reside na formação humana, na colheita de saberes das pessoas envolvidas na condução dos trabalhos infantis. Não há como deixar de refletir sobre a formação musical tradicional no Ocidente depois do encontro com afinações diferentes que existiam não apenas nas expressões tradicionais, mas também na "estranha" harmonização coral ${ }^{62}$ que funcionava dentro daquela proposta;

Sindou, onde estavam muitas crianças que viam pela primeira vez pessoas de outras nações, cujos os olhares infantis atentos foram cativados por essa canção.

58 Por coincidência, Lutero lança um olhar à mesma experiência em seu livro recém-lançado no Brasil. (FUCCI-AMATO; GALATI, p. 253).

59 Giovanna Marini, etnomusicóloga italiana, especialista em cantos tradicionais italianos, diz que "no canto de tradição oral um dos objetivos é 'chegar'. Ao se referir à voz do cantor popular, esse 'chegar' é descrito como 'uma voz empurrada', uma voz que é mandada a bater-se contra a cabeça, o crânio, as maçãs do rosto [ossos zigomáticos], quase como se cantasse 'dos olhos', como se a voz devesse sair dos olhos." (MARINI, 200?, tradução nossa).

Essas características descritas por Marini em relação aos cantores populares italianos são as mesmas encontradas nos cantos tradicionais burkinabês, assim como em muitas comunidades brasileiras de tradição oral.

$60 \mathrm{O}$ " $r$ " rolado a que a pesquisadora se refere, é parecido com a pronúncia do português de Portugal ou do paulistano do começo do século passado.

61 Balafon, forma pela qual ficou conhecido o bala, instrumento de percussão da família do xilofone, encontrado no Sudão e na Guiné (África). É constituído de dezesseis a dezenove plaquetas de madeira sobre cabaças que funcionam como caixa de ressonância (ANDRADE, 1999, p. 41). Como vemos, é também encontrado em Burkina Faso.

62 A tradição coral ocidental em Burkina Faso é muito recente: seu primeiro coro a quatro vozes mistas nasceu em 1984. Segundo Magro (1997), as formações corais nesse país "são sempre criadas no âmbito das comunidades religiosas (pelo menos em uma primeira fase). O canto polifônico estruturado na base das regras musicais europeias não é um elemento originário da sua cultura, mas, como em muitos outros países colonizados, é herança da penetração evangélica." Talvez essa história coral recente explique as harmonias "estranhas" que ouvi: da estrutura coral ocidental eram preservadas as quatro vozes mistas, ora homofônicas, ora polifônicas, recheadas pelos timbres, ritmos e afinações particulares de suas tradições. 
após as apresentações corais nas quais voz e corpo se fundem na dança a capela ou com acompanhamento instrumental; e, principalmente, depois de constatar a possibilidade de uma maneira espontânea de aprender música, ligada à vida cotidiana, como relatou o diretor do coro de Ouagadougou durante o nosso encontro de troca teórica musical e técnica vocal:

\begin{abstract}
Naquela ocasião, o diretor do coro de Ouagadougou nos explicou que a técnica não é fruto de uma escolha de trabalho precisa, como pode ser no nosso caso, mas que se adequa ao próprio modo espontâneo de cantar que é caracterizado pelo uso mais "explosivo" da voz. O som da voz é geralmente acordante com os instrumentos musicais... Outras vezes, a voz vem impostada segundo as circunstâncias, como por exemplo: o som é mais gutural e fechado no caso de acompanhamento fúnebre e, em geral, nas situações de dor e tristeza, enquanto é mais "vivaz" e agudo nas situações alegres, como nas festas de casamento. (MAGRO, 1997, p. 9-10, tradução nossa)
\end{abstract}

Nesse mesmo encontro, perguntamos ao diretor da escola de música da capital como a técnica vocal era ensinada. Ele nos olhou espantado e, depois de pensar um pouco, respondeu que não curavam os ataques de soluço nas crianças porque esses desenvolviam a caixa torácica, e acrescentou: "As vozes tradicionais são, ainda hoje, muito presentes e trazem com elas memórias antigas. Os africanos são fortes de uma tradição que não precisa de técnica, porque a voz que sai de suas bocas é a voz de sua alma." (MAGRO, S. 1997, p. 10, tradução nossa).

Depois da turnê e das férias, sedentos por compartilhar nossas experiências, voltamos a Milão sem local de ensaio para o Coro Curumim, pois a parceria com a escola de música II Classico havia terminado, pelos motivos expostos anteriormente. É nesse momento que se inicia a fecunda parceria com a Società Umanitaria.

De acordo com o esboço de um cartaz e do TG Coro, uma circular interna da ACC sobre suas atividades, a primeira chamada para montar um coro infantil na SU foi para o dia 20 de novembro de 1996 (ver ANEXOS G e H). Recorrendo à memória e a um resumo das atividades que fizemos para a SU, o coro teve início apenas em outubro de 1997 (ver ANEXO I). 


\section{Coros Curumim na Società Umanitaria no ano letivo de 1997/1998}

Inicia-se a parceria com a Scuola di Musica per bambini da SU. O trabalho foi criar quase do zero um novo coro infantil, pois, das crianças que cantaram conosco em outros grupos, apenas duas vieram fazer parte deste novo Curumim. Começamos com dois grupos de crianças muito pequenas (ver ANEXO J), e com uma grande equipe de trabalho: eu, Claudia, Pilar e Ernesto, além do apoio de Lutero como diretor artístico (ver ANEXO K).

Pilar Bravo era uma jovem espanhola, da Catalunha, estudante de regência, contrabaixista, pianista e com um belo timbre de voz de mezzo-soprano. Além de suas qualidades como musicista, trabalhou com os grupos a canção em língua catalã $L a$ Gata y El Belitre, que a mestranda encontrou em um livro em Barcelona; Ernesto Ferrini, italiano, era tenor do Coro Cantosospeso e professor de escola fundamental, trazendo aos grupos uma referência masculina e sua experiência em pedagogia.

Em maio de 1998, os dois grupos do Curumim participaram de uma peça de teatro, II Negozio dei Giocattoli (ver ANEXO L), junto com os alunos de iniciação musical de Antonio Testa, pedagogo musical e percussionista italiano, que também trabalhava na SU e idealizou essa apresentação dirigida aos pais e familiares dos alunos. Nessa apresentação, as crianças cantaram Palomita Blanca, Os Brinquedos, Minha Canção e La Lune est Mort (canção francesa com letra de Jacques Mareuil e música de Georges Liferman, de 1968).

Além das canções já citadas, trabalhamos também N'Kosi Sikeleli Africa e Milho Verde.

\section{Coros Curumim na Società Umanitaria no ano letivo de 1998/1999}

Continuamos com dois grupos de crianças, agora divididas em iniciantes e avançadas, para prosseguir com o desenvolvimento daqueles que participaram dos 
grupos em 1997/1998 e abrir portas para novos curumins. A equipe de trabalho diminuiu, saíram Pilar e Ernesto, e ficamos apenas eu e Claudia a trabalhar diretamente com as crianças.

Em 1999, fizemos um concerto aberto ao público e não apenas aos familiares, apoiados pelo Coro Cantosospeso, ao ar livre, no Chiostro dei Glicini, na SU (ver ANEXOS $M$ e $N$ ), um espaço agradável, perfumado pelas glicínias lilases e com excelente acústica. Junto com o Coro Cantosospeso, as crianças cantaram N'Kosi Sikeleli Africa, II Treno, Mwuana Kondo (canção tradicional do Quênia, presenteada pelo grupo infanto-juvenil Kambilolo), Minha Canção e Era Nato Poveretto (canção tradicional italiana, com arranjo do famoso pianista Michelangelo Benedetti), e, sozinhas, apresentaram Palomita Blanca e La Lune est Mort.

Ensaiamos, mas não apresentamos, as seguintes canções: a melodia de Borboleta (canção tradicional brasileira), Anin a Nolis (canção infantil tradicional do Friuli, Itália), L'orchestra (quodlibet ${ }^{63}$ inglês, traduzido para o italiano pela mestranda, a cinco vozes que imitam instrumentos musicais) e o Canto Txucarramae.

\section{Coros Curumim na Società Umanitaria no ano letivo de 1999/2000}

Devido à continua chegada de novas crianças, abrimos um terceiro grupo para iniciantes, às quartas-feiras, obtendo a seguinte divisão: coro de principiantes, de intermediários e de avançados, em um total de 47 crianças. A equipe de trabalho continuou a mesma, ou seja, eu e Claudia, com a direção artística de Lutero.

Nesse ano letivo, fizemos parte de uma manifestação coral promovida pela ACC, Mille Voci per la Pace, uma passeata que se concluía com um concerto no Duomo di Milano, junto a outros 27 coros (ver ANEXO O); participamos de um encontro de corais infantis promovido por Susan Lovegrove Graziano ${ }^{64}$ (ver ANEXOS P e Q), no

63 Quodlibet é uma forma de composição de caráter scherzoso (brincalhão) que consiste na contraposição de melodias diversas, seja pelo tom do texto, seja pela música.

64 Susan Lovegrove Graziano é uma regente coral inglesa radicada em Milão, Itália, desde os anos 70. Formada em Pedagogia da Voz em New England Conservatory of Music de Boston, USA, 
qual cantamos Tche Nane (canção tradicional dos índios Jabuti do Brasil, com adaptação para coro infantil feita pela mestranda a partir da partitura de Marluí Miranda), Era Nato Poveretto, Palomita Blanca, II Treno, Duetto Buffo di due Gatti (de Gioachino Rossini), N'Kosi Sikeleli Africa e Cuckoo ${ }^{65}$, do compositor inglês Benjamin Britten, analisada no segundo capítulo, no item 2.1.2.; e fizemos a apresentação de final de curso que repetiu o mesmo programa (ver ANEXO R). Nesse último concerto, fomos acompanhados ao piano por Carlo Palese, professor de piano da SU, nas peças de Rossini e Britten, escritas para vozes superiores e piano. As outras canções foram realizadas a capela pelas crianças e, pela primeira vez, Claudia regeu uma música em concerto: Era Nato Poveretto.

Vale ressaltar aqui que, após anos de trabalho e tentativas de construir um coro infantil que pudesse ter uma performance artística aceita pelo público em geral e não apenas por pais e familiares "tendenciosos", o sonho foi realizado! Realizado graças a muito esforço, carinho e dedicação da equipe de trabalho e das crianças, e do apoio que essas atividades tiveram por parte da ACC e da SU. Para que todas as crianças dos três grupos corais participassem das apresentações, independentemente do estágio musical em que se encontravam, e chegássemos a um resultado artístico, tivemos o cuidado de deixar a cargo do grupo de quinta-feira (o grupo avançado) as canções mais complexas: Cuckoo! e I/ Duetto Buffo di due Gatti. Nas outras canções todos os grupos cantaram, ou seja: nas canções mais simples, o coro avançado apoiou os outros dois grupos de crianças.

Além das canções acima, ensaiamos Minha Canção, Anin a Nolis, Os Brinquedos, L'Orchestra, a melodia de Canção Amiga, Nikaiedo e Pirulito que Bate Bate (canção infantil popular brasileira).

Observamos que foi bem difícil fazer Pirulito que Bate Bate! Levamos a canção na intenção de fazer brincadeiras com as mãos em duplas e desistimos da ideia diante

especializou-se em música de câmera vocal na Ecole Normale de Musique de Paris. Fundou e regeu o quinteto vocal I madrigalisti di Milano entre 1972 e 1983 e por 25 anos ensinou didática da voz e do canto coral no CEMB (Centro de Educação Musical de Base). Em novembro de 1999, publicou um livro sobre a didática do canto na escola, Oggi si canta, e é diretora, ainda hoje e desde seu nascimento em 1986, do grupo IL laboratório Corale di Milano (IL LABORATORIO CORALE DI MILANO, 2013).

65

Essa peça, Cuckoo!, não consta do programa de concerto do Happening Corale, mas é quase certo que a canção foi realizada ali - ou em outra situação - porque, numa das apresentações dessa música, a mãe de uma das crianças foi nossa pianista acompanhadora. 
da dificuldade do grupo em cantá-la. Quem poderia imaginar que, para os italianinhos, aquele ritmo era tão estranho a ponto de não conseguirem sequer memorizar uma melodia tão simples para nós brasileiros? Gastamos alguns ensaios com a aproximação de nossos curumins a esses ritmos, tão diferentes da sua cultura, mas não introduzimos as brincadeiras com as mãos. Um dia a canção saiu, mas sempre ficou certa dureza, falta de ginga, apesar de a criançada ter plena certeza de cantá-la fielmente.

Relatamos esse fato por considerarmo-lo de fundamental importância quando tratamos de um repertório multicultural: a consciência de nossos limites ao interpretar manifestações musicais de outras culturas. Assim como os italianinhos, nossos filtros culturais estão presentes na apreensão do repertório multicultural.

\section{Coros Curumim na Società Umanitaria no ano letivo de 2000/2001}

Nossa equipe de trabalho foi acrescida da presença de Laura Comin, cantora do Coro Cantosospeso e de La Fucina Vocale, formada em pedagogia, que trouxe sua alegria, sua experiência com crianças e seu timbre escuro de contralto.

Continuamos com os três grupos corais: o de iniciantes, o intermediário e o avançado. Algumas crianças do curso de iniciantes do ano letivo anterior passaram para o avançado ou para o intermediário, e algumas do intermediário passaram para o avançado, de maneira que deixamos os ensaios das quartas-feiras para receber novos cantorezinhos ${ }^{66}$.

${ }^{66}$ Os critérios usados para encaminhar as crianças aos grupos intermediário e avançado eram principalmente as aptidões musicais, tais como afinação, emissão vocal, facilidade em manter a melodia de seu naipe, senso rítmico e noções de leitura da partitura; e as qualidades atitudinais, tais como concentração, atenção, participação nas atividades propostas, disposição em colaborar com o grupo etc. Esses critérios serviam como base de avaliação dos progressos das crianças, mas não foram usados a ferro e fogo: foram abertas exceções para crianças com menor facilidade musical, mas que expressavam forte vontade de participar do grupo avançado; algumas permaneceram ou entraram num grupo não adequado às suas capacidades porque era o único dia em que podiam frequentá-lo; e teve o caso de um menino (Michel), que, se tivesse considerado apenas seu "descomportamento", jamais teria frequentado o grupo avançado! A experiência mostrou que, mais importante que as habilidades musicais e atitudinais, o que vale é a vontade de participar: as crianças que tinham mais vontade foram as que acabaram se desenvolvendo mais musicalmente, como Virginia, uma criança que, ao entrar, sabia só falar no ritmo, e que, pela vontade, foi aprendendo a 
No final de 2000, os curumins participaram do Concerto de Natal com os coros da ACC, cantando a parte de soprano e contralto de Adeste Fidelis; a canção Hodie Christus Natus Est, do álbum de canções natalinas a três vozes superiores; A Cerimony of Carols de Benjamin Britten; e N'Kosi Sikeleli Africa.

Em 2001, o Coro Curumim foi convidado para gravar a música Festa ${ }^{67}$, do compositor italiano Sebastiano Cognolato. Esta canção foi composta especialmente para a festa da música em Milão, servindo como vinheta em canais de rádio e televisão para a chamada da festa. O CD, sem fins lucrativos, foi apoiado pela Associazione Festa della Musica - Milano e pela Unicef ${ }^{68}$ (ver ANEXO S).

$\mathrm{Na}$ gravação do dia 31 de março de 2001, podíamos levar apenas 20 das nossas crianças, devido ao tamanho do estúdio, ou seja, tínhamos que escolher as crianças que participariam. Essa é uma situação difícil, delicada; estávamos lidando com seres humanos, não apenas com vozes. O critério de escolha principal foi, sim, o musical, ou seja, as crianças que cantavam melhor, mas algumas vieram mesmo sem ter as qualidades musicais necessárias para um registro, só porque queriam muito ${ }^{69}$.

Em maio de 2001, o Coro Cantosospeso fez uma turnê por Portugal acompanhado pelo violeiro Ivan Vilela ${ }^{70}$, agora professor Doutor do departamento de música da ECA - USP. Ao término da turnê, fizemos um concerto no Salone degli Afrescchi da Società Umanitaria, com os coros adultos da ACC e o nosso violeiro. Esse concerto foi dividido em duas partes: na primeira, os coros adultos cantaram um repertório de música brasileira a capela e a música Rosa Amarela (canção tradicional

emitir frequências musicais. Ela começou a cantar tão bem que sua mãe decidiu levá-la para fazer o teste para entrar no Coro Infantil do Conservatório de Milão, e ela acabou passando em segundo lugar.

67 Além do Coro Curumim, a música de Cognolato foi interpretada na voz de Gabin Dabirè, com percussões de Paul Dabirè, viola de Francesco Lattuada e piano de Andrea Rebaundengo.

68 Por questões de direitos autorais, que envolvem diversos profissionais, não podemos anexar a canção a este trabalho.

69 Apenas uma das crianças que queriam muito não pôde ser levada porque, além de cantar quase falando, era um garoto muito agitado e bagunceiro. Não lembro exatamente como falei com ele sobre isso, só lembro que não foi uma conversa fácil e ele acabou chamando a mãe, para quem expliquei a situação. Nesses momentos, é preciso ter muita clareza dos propósitos para manter a firmeza de uma decisão "desagradável", mas necessária, se beneficiar o grupo como todo. E, naquele momento, podíamos levar apenas vinte crianças que se mostrassem, sobretudo, aptas a enfrentar horas de estúdio.

70 Ivan Vilela, violeiro e professor Doutor no departamento de música da ECA - USP. Trabalha há mais de 20 anos com pesquisa de cultura popular. Concluiu seu doutorado - Uma História Social da Música Caipira - em Psicologia Social pela Universidade de São Paulo, em 2012. 
brasileira arranjada para coro a quatro vozes por Heitor Villa-Lobos), com o acompanhamento de viola caipira; e o coro Curumim preparou, especialmente para a ocasião, a melodia de Asa Branca (canção de Luiz Gonzaga), para combinar com a elaborada versão dessa mesma canção, inserida no CD Paisagens ${ }^{71}$, feita por nosso violeiro. Foi um momento mágico para as crianças, para o público, para os músicos... É uma pena que não tenha nenhum registro escrito, ou de vídeo ou áudio do encontro das vozes infantis com a delicadeza encantada dos sons tangidos por Ivan, sendo a única prova a memória emocional dos que viveram aquele momento.

Além das canções acima apresentadas em concerto, ensaiamos as seguintes músicas: Palomita Blanca, Minha Canção, Il treno, Era Nato Poveretto, Mwana Kondo, Anin a Nolis, L'Orchestra, Nikaiedo, Duetto Buffo di due Gatti, Cuckoo!, Younder come Day (negro spirituals) e Das Klinget so Herrlich (coro dos escravos da Flauta Mágica de Mozart), analisada nesta dissertação no item 2.1.3. do segundo capítulo.

\section{Coros Curumim na Società Umanitaria no ano letivo de 2001/2002}

Depois de dois anos de "glória", as condições já não eram mais favoráveis. A direção da escola de música que abrigava e apoiava os coros infantis, devido às pressões externas relativas ao contexto socioeconômico de uma Itália em crise e a novos objetivos financeiros vindos da direção da SU, decidiu que os cursos de canto coral infantil não davam os lucros esperados. Portanto, cortaram um dos nossos grupos e o pagamento de um dos nossos assistentes, assim como aumentaram o custo das quotas de participação das crianças. O resultado foi a redução pela metade das quarenta crianças que tínhamos no ano letivo 2000/2001, empobrecendo um trabalho calcado em qualidades humanas.

Nesse ano letivo, não fizemos apresentações públicas, pois os curumins estavam sem condições de mostrar um trabalho com as mesmas qualidades artísticas dos anos anteriores: estávamos desfalcados, com uma equipe técnica incompleta e

\footnotetext{
${ }^{71}$ Asa Branca está na quinta faixa do CD Paisagens de Ivan Vilela (VILELA, 1998).
} 
com poucas crianças. Para "segurar a bola", eu e Claudia focamos no crescimento musical das crianças por meio de aulas de escuta musical, aulas de noções da escrita musical, aprofundamento (com o grupo avançado) da técnica vocal e repertório, e muitas atividades lúdicas.

As crianças, nesse período, cantaram e brincaram com o seguinte repertório musical: N'Kosi Sikeleli Africa, Palomita Blanca, Minha Canção, Era Nato Poveretto, Anin a Nolis, Duetto Buffo di due Gatti, Cuckoo!, Younder come Day, Borboleta, Milho verde, Canção Amiga, Das Klinget so Herrlich, A la Orilla del Agua (canção tradicional argentina), Venite, venite (adaptação para vozes infantis feita pela mestranda do coro masculino do Oratorio Gionna de Giaccomo Carissimi), Corre, Cotia (canção tradicional infantil brasileira), Su, su, su ch'el Giorno é Fore, Sapo Cururu (canção tradicional infantil brasileira, em arranjo feito para duas vozes pela mestranda com texto em português e em italiano), Alla Fiera di Mastro Andre (canção tradicional italiana) e La Lune est Mort.

Foi um ano de intensa atividade interna e, como observamos, trabalhamos com um repertório ampliado em relação aos anos anteriores. Nesse ano, as crianças do grupo avançado começaram a usar o diapasão para encontrar notas próximas e aprenderam a grafia musical tradicional das mesmas; brincamos com as figuras das notas, ouvimos sons de orquestra, desenhamos nosso repertório, inventamos histórias e as encenamos. O descompromisso com a performance acabou por abrir uma janela temporal para atividades centradas no crescimento musical dos pequenos.

\section{O Coro Curumim na Libreria Claudiana (ver ANEXO T) e a preparação ao canto coral na Scuola di Via Guicciardi no ano letivo 2002/2003}

Finda a parceria entre o Curumim e a SU, alugamos uma sala na Libreria Claudiana e prosseguimos com as poucas crianças que restaram depois de um ano difícil de trabalho: Emma Rietti, Danae Riklos, Carlotta Broglio, Virgilio Lutero, Michel Rossini, Alice Margonari, Angelica Foletto, Sofia, entre outros. A equipe de trabalho é 
acrescida pela presença de Laura Lagona, coralista de La Fucina Vocale e do Coro Cantosospeso, que nos ajudou nas questões burocráticas e nos emprestou sua bela voz de mezzo-soprano. O trabalho nesse ano foi focado em canções a três vozes porque - apesar de estarmos em número reduzido, essas crianças tinham muita experiência coral, pois já cantavam conosco há entre três a nove anos - e nas canções que as crianças queriam cantar do repertório antigo, e prosseguimos com as aulas de noções de escrita musical. Fizemos N'Kosi Sikeleli Africa, Palomita Blanca, Minha Canção, Era Nato Poveretto, Duetto Buffo di due Gatti, Cuckoo!, Younder come Day, Das Klinget so Herrlich, aproximação da partitura ${ }^{72}$ de Turot Eszik a Cigany (peça a quatro vozes infantis de Zoltan Kodaly), Dona Nobis Pacem (cânone a três vozes de Mozart) e introduzimos o arranjo a três vozes de Tzun Tiãn Lai (canção infantil em mandarim), analisada nessa dissertação no item 2.1.6. do segundo capítulo.

Concomitantemente com o Curumim da Libreria Claudiana, Claudia inicia um coro infantil na Scuola di Via Guicciardi, como regente titular, com meu apoio e "visitas" mensais.

Em junho de 2003, realizamos uma apresentação para pais e familiares na Scuola di Via Guicciardi, em que reunimos os dois grupos de crianças e alguns cantores da ACC que vieram apoiar os Curumins. Nessa ocasião, cantamos, entre outras canções, Tzun Tiãn Lai.

\subsubsection{Atividades Paralelas aos Grupos Corais do PIC}

Essas atividades paralelas consistem em concertos com coros infanto-juvenis, atividades musicais em cursos de verão, espetáculos músico-teatrais realizados por crianças ou voltados à infância, e uma palestra sobre a infância no Brasil. As crianças

72 Turot Eszik a Cigany (Os ciganos gostam de ricota), de Zoltan Kodaly, foi escrita em duas versões: para quatro vozes mistas e para quatro vozes superiores. Preferi usar o termo "aproximação da partitura" por ser mais condizente com o que ocorreu. Essa música foi usada como estudo e não chegou a ser apresentada em público, mas ajudou a desenvolver a independência das vozes, pois contávamos com uma média de duas crianças por naipe, mais a ajuda da equipe de trabalho, ou seja, mais ou menos três pessoas em cada melodia. 
dos coros Curumins não participaram de maneira ativa nessas atividades, mas foram convidadas, junto com seus pais, a assistir a algumas dessas manifestações, assim como receberam parte do repertório musical dessas atividades, as quais permitiram também que novas crianças entrassem nos coros estáveis. Ou seja, existiu uma intercomunicação entre as atividades corais e as que chamamos de paralelas.

\section{Vamos Brincar!}

Meses antes de iniciar o primeiro coro Curumim, foi realizado um espetáculo multimidial em Crotona, na região da Calábria, Itália, no dia 5 de maio de 1993, promovido pelo Centro Ricerca Documentazione Comunicazione pace Disarmo Cooperazione e Sviluppo Crotone ${ }^{73}$, em que a mestranda participou como regenteassistente do maestro Lutero. Esse trabalho foi desenvolvido durante um ano ${ }^{74} \mathrm{com}$ crianças de algumas escolas da região e jovens voluntários da cidade, com uma equipe de artistas de origem latino-americana e italiana, por meio de laboratórios de dança, música e teatro focados na cultura dos povos africanos e latino-americanos. Do espetáculo Vamos Brincar (ver ANEXO U) também participou o coro adulto Canta e Cammina da paróquia de S.Domenico di Crotone, ensaiados pela mestranda e por Lutero. A canção, que leva o título do espetáculo, também conhecida como Os Brinquedos, fez parte do repertório musical do Curumim por vários anos, como vimos anteriormente.

73 "Centro de pesquisa, documentação e comunicação pela paz, desarmamento, cooperação e desenvolvimento, com sede em Crotona que, pelo estatuto, segue as citadas finalidades, desenvolvendo estudos e pesquisas, adquirindo, conservando e colocando à disposição da coletividade documentos, materiais escritos e audiovisuais e também colaborando em eventuais organizações de atividades específicas nas escolas de qualquer ordem e grau." (REGIONE CALABRIA, 1990, tradução nossa)

74 Participei apenas da fase final do trabalho, na última semana de elaboração do espetáculo. 


\section{Leitura musicada da obra de Jorge Amado, O Gato Malhado e Sinhá Andorinha: uma história de amor e Debate sobre as Crianças do Brasil $^{75}$}

Entre 24 e 27 de maio de 1995, a ACC, em colaboração com o COE, Centro orientamento educativo, apresentamos a manifestação cultural Quattro giorni nei dintorni di Bahia (Quatro dias nas vizinhanças da Bahia) (ver ANEXO V), na qual a população milanesa teve a oportunidade de se aproximar da cultura desse estado brasileiro por meio de conferências, debates, espetáculos teatrais, concertos, rodas de samba e capoeira, mostra de aquarelas e culinária.

Duas atividades dessa manifestação cultural tiveram como tema a infância: a leitura musicada da obra $O$ Gato Malhado e a Andorinha Sinhá: uma história de amor, de Jorge Amado, publicada em italiano com o título II gatto tigrato e Miss Rondinella, feita por atores, pelo Coro Fabalalavos da ACC e com cenário e máscaras produzidos por crianças da pré-escola; e o Debate sobre as crianças do Brasil, dirigido pelo historiador e ex-senador italiano pelo partido Rifondazione Comunista, José Luis Del Royo, uma pedagoga brasileira e representantes do Consulado Geral do Brasil (ver ANEXO W).

\section{Concertos de coros infanto-juvenis ${ }^{76}$}

Além dos inúmeros concertos públicos da ACC a que pais e crianças eram convidados a assistir, destacam-se dois feitos por crianças: o concerto In-Canto (ver ANEXO X), no dia 10 de junho de 1995, com o coro La Fucina Vocale da ACC e o Coro di Voci Bianche e Giovanili della Civica Scuola di Musica di Cassate Nuovo regido por

\footnotetext{
Nessa atividade participei como cantora e preparadora do Coro Fabalalavos.

76 Nessas atividades, participei na função de cantora e regente-assistente dos grupos La Fucina Vocale e Coro Cantosospeso.
} 
Giorgio Ubaldi ${ }^{77}$, do qual, anos mais tarde, usamos uma canção de seu repertório, Duetto buffo di due Gatti; e as apresentações do Coro infanto-juvenil de crianças do Quênia, o Kambilolo Village Dance Group ${ }^{78}$ da Missa Luba, ao lado do Coro Cantosospeso da ACC (ver ANEXO Y), em dezembro de 1998, que nos presenteou com a canção Mwana Kondo.

\section{Girotondi e Filastrocche (ver ANEXO Z)}

Cirandas e Parlendas ${ }^{79}$ foi um espetáculo dirigido por Ricardo $\mathrm{Fuks}^{80}$, realizado nos dias 21 e 26 de fevereiro de 1999, com atores profissionais e de seu curso de teatro da SU, e com um grupo de crianças extracomunitárias da Scuola Elementare di Grattosoglio. Com as crianças e professores foram feitos laboratórios semanais durante dois meses, nos quais eu e Claudia escolhemos as canções de diversas nacionalidades das crianças e a inserção de outras adequadas ao grupo para serem cantadas no espetáculo. As canções escolhidas foram Escravos de Jó (canção infantil tradicional brasileira), Asserin, asseran, los Maderos di San Juan (canção tradicional infantil da argentina), a melodia principal de N'Kosi Sikeleli Africa e Tzun Tiãn Lai, canção infantil em mandarim, cantada e interpretada com gestos por uma doce criancinha de olhos amendoados.

${ }^{77}$ Giorgio Ubaldi é um reconhecido educador musical e regente coral italiano, autor do livro usado nesta dissertação Cantintondo - 138 Canoni Popolari di tutto il mondo per tutte le età, Edizioni Carrara, Bergamo, 2005.

78 Kambilolo Village Dance Group é um grupo "composto por dezesseis meninos do Quênia, de 11 a 16 anos. Pertencem à etnia Giriama, uma das nove tribos reconhecidas pela língua e tradição Swahili. $O$ grupo é de Watamu, pequeno vilarejo que dista em torno de uma centena de quilômetros de Mombasa. Porta-voz de sua comunidade, o musicista, professor de música e trompetista de fama internacional, Daniel Kazungu, dirige e coordena os meninos do grupo. O Kambilolo Village Dance Group veio, pela primeira vez, à Itália em 1997, onde se exibiu em festival, e dentro de igrejas e escolas, projetando um repertório ligado às tradições de sua terra, entre cantos e danças, com símbolos e ritmos típicos da Grande Mãe África." Tradução nossa, extraída do programa de concerto Messa Luba com Coro Cantosospeso e Kambilolo Group (ver ANEXO X).

79 Filastrocca é parlenda em português, que, segundo o dicionário Houaiss, significa "declamação poética para crianças, acompanhada por música; rima infantil utilizada em brincadeiras ou como técnica de memorização".

80 Ricardo Fuks, argentino, é diretor de teatro radicado em Milão, Itália, e coordenava os cursos de teatro da SU, a Scuola di Teatro. Sob sua direção, realizei também espetáculos como cantora: Platero y yo, Che: Io non assomigilio a Che Guevara e Verde Sonnambulo. 


\section{Laboratórios de férias para crianças na Società Umanitaria}

Esses laboratórios de férias, realizados nos meses de junho e julho, eram pensados para as crianças que, ao término das aulas escolares, por vários motivos, tais como pais que ainda trabalhavam, falta de oportunidades ou falta de dinheiro, não saíam de Milão. Nesses cursos, eram oferecidos diversos laboratórios criativos, dependendo do ano e das pessoas que trabalhavam nas atividades, como música, recitação, bricolagem, laboratório de cinema de animação, dança, laboratório de construção de marionetes etc. (ver ANEXO AA).

As crianças que chegavam ao Pincopallino ${ }^{81}$ estavam cansadas das aulas da escola, sedentas pelas férias e queriam, com justiça, brincar! As atividades dos laboratórios eram dirigidas principalmente a proporcionar momentos de prazer, por meio de jogos e brincadeiras, de acordo com o métier de cada operador.

Os documentos oficiais que comprovam meu trabalho nesses cursos referemse aos anos de 1998 (ver ANEXO BB) e de 2000 (ver ANEXO CC), uma carta não oficial explicando o percurso do trabalho realizado com as crianças no ano de 2002 (ver ANEXO DD) e um caderno com anotações a mão das atividades desenvolvidas naquele verão, do qual aqui anexamos a primeira página (ver ANEXO EE).

Nesses laboratórios, realizados pela mestranda e Claudia, coordenados, inicialmente, por Ricardo Fuks e, posteriormente, por Graziella Libermann, nos divertíamos com as crianças propondo atividades lúdicas não apenas musicais, mas também contávamos estórias ligadas ao repertório musical, para depois trabalhar a representação delas. Também organizávamos a criação de cenários, enfeites e desenhos feitos pelas próprias crianças, promovíamos a audição de músicas e vídeos ligados ao tema proposto, e brincávamos, brincávamos muito, porque, afinal, em teoria, estávamos todos em férias!

${ }^{81}$ Essas atividades de férias ganharam nomes diferentes ao longo dos anos. Começou com o nome de Pincopallino, depois passou para Pianeta dei bambini, e, mais tarde, ganha o nome de Estate Bambini, parte de Le Botteghe dell'Umanitaria. 
Esses laboratórios foram, pessoalmente, um desafio. Nos coros, contávamos com a presença das mesmas crianças ao menos por 32 ensaios ${ }^{82}$, favorecendo a construção do grupo pela possibilidade de atenção individual e desenvolvimento de relações afetivas. Era mais fácil a programação de ensaios que "funcionassem", pois, após alguns encontros, já nos reconhecíamos; as regras e os espaços de expressões eram definidos; conhecíamos as habilidades das crianças e suas relativas deficiências, assim como as crianças nos conheciam; enfim, havia a possibilidade de formar um grupo com características próprias, o que não acontecia nos laboratórios de verão, dado o pouco tempo de contato e grande rotatividade de crianças.

Nos laboratórios de verão a permanência das crianças era muito variada, desde aquelas que o frequentavam por inteiro, até aquelas que permaneciam por uma semana. A idade das crianças também era variada, de quatro a dez anos ${ }^{83}$, assim como suas preferências e aptidões artísticas, habilidades e até mesmo nacionalidades ${ }^{84}$, e não tínhamos nenhuma informação sobre quem eram essas crianças antes do início das atividades. Devido a essas características, éramos obrigadas a ser flexíveis: em todos os laboratórios seguíamos um tema que era desenvolvido com muito "jogo de cintura", para que as crianças que participavam por pouco tempo se sentissem parte da construção do percurso escolhido, para que aquelas que chegassem no meio das atividades pudessem se inserir, e para que aquelas que permaneciam durante todo 0 verão não ficassem desestimuladas com repetições.

O primeiro laboratório de verão, em 1998, coordenado por Ricardo Fuks, teve como tema II regno del rovescio (O reino ao contrário), canção da poetisa e música argentina María Elena Walsh ${ }^{85}$. O único material que restou desse laboratório foi uma partitura dessa canção feita pela mestranda e o comprovante de pagamento da

82 O número de ensaios de um ano letivo para grupos que se encontravam uma vez por semana era em torno de 32, excluindo os ensaios extras para concertos e outras atividades. Portanto tínhamos, no mínimo, 32 ensaios, com as mesmas crianças, salvo exceções, como entradas ou saídas no meio do curso.

83 No último laboratório de verão, no ano de 2002, a idade foi ampliada até 14 anos, mas nos nossos laboratórios continuamos apenas com crianças de 4 a 10 anos (ver ANEXO FF).

84 A maior parte das crianças era italiana, mas contávamos com muitas crianças adotadas, algumas recém-chegadas, como as irmãzinhas indianas e o menininho ucraniano, e filhos de imigrantes extracomunitários.

${ }^{85}$ María Elena Walsh, cidadã ilustre de Buenos Aires , foi a "escritora argentina que musicou a infância de milhões de argentinos com suas canções e seus poemas."(FOLHA DE SÃO PAULO, 2011). 
atividade, informado anteriormente. Como aqui posso contar apenas com lembranças sem nenhum apoio de documentos, nem mesmo de anotações em cadernos de trabalho, prefiro não entrar em detalhes sobre as atividades desenvolvidas.

Em 2000, o tema geral dos laboratórios de férias foi Incontri con persone, luoghi, storie reali e immaginarie (Encontros com pessoas, lugares, histórias reais e imaginárias), onde encaixamos nosso tema: Fiabe e suoni amazzonici (Lendas e sons amazônicos):

O objetivo dessa atividade é despertar a curiosidade das crianças pela Amazônia, oferecendo elementos de cultura geral sobre a área: os habitantes, a "arquitetura", os principais rios, a fauna e a flora, por meio de contos das principais lendas amazônicas, cantos e improvisações sonoras, apresentados de maneira lúdica e com vários jogos musicais entrelaçando essas atividades. Cada semana tem, como tema, um animal, uma planta ou um personagem extraído das lendas indígenas, e as atividades se desenvolvem em torno deles: audições musicais, sonorização das lendas, representações gráficas e corporais dos personagens ou ambientes escolhidos ${ }^{86}$. (ver ANEXO GG, tradução nossa)

Segundo as anotações, introduzimos o laboratório pegando um barco imaginário para chegarmos à sala vazia, e ali teríamos que construir a floresta amazônica. Para tanto, perguntamos às crianças: $O$ que existe na floresta amazônica? Que tipo de vegetação? Quais são os animais? Existem insetos? Existem seres humanos? (ver ANEXO HH). Assim, iniciamos nossa "viagem" com improvisos vocais e corporais com os sons da floresta e seus animais; contamos a história da Onça e o Jabuti $^{87}$ e ensaiamos a canção Mekô Merewá, analisada nessa dissertação no item

${ }^{86} \mathrm{Na}$ proposta do laboratório, encontramos um erro: na verdade falamos sobre a região da selva amazônica que pertence ao Brasil - que cobre $74 \%$ da Amazônia Legal, criada pelo governo brasileiro em 1966, e que compreende os Estados do Maranhão, Pará, Tocantins, Amapá, Amazonas, Roraima, Acre, Rondônia, Mato Grosso - e não sobre a Amazônia. Também usamos um mapa da América Latina para mostrar que a selva amazônica encontrava-se, em sua maior parte, em território brasileiro $(60 \%)$, mas também fazia parte do Peru (13\%) e tinha pequenas quantidades espalhadas pela Colômbia, Venezuela, Equador, Bolívia, Guiana, Suriame e Guiana Francesa. Com exceção do vídeo que mostramos sobre o povo Yanomami, que se encontra em território brasileiro e se estende para o lado venezuelano, o laboratório centrou-se em lendas e cantos pertencentes à região amazônica em território brasileiro.

87 No livro Mitos Amazônicos da Tartaruga, de Charles Frederik Hartt, Editora Perspectiva, 1977, pág. 57, encontrei a essência desse conto intitulada Como o Jabuti venceu o Veado na Carreira; nas fábulas de Esopo, temos a Lebre e a Tartaruga. A história que contei na época tinha como objetivo apresentar os animais da floresta amazônica: peguei a essência do conto tradicional, onde o fraco, porém mais inteligente, vence o mais forte e arrogante, e fiz uma recriação com as crianças, que será abordada no capítulo 3 desta dissertação. 
2.1.4. do segundo capítulo; contamos a história A Festa no Céu para introduzirmos a canção Sapo Cururu; fizemos uma tradução para o italiano, livre e resumida, do conto $O$ menino que não sabia sonhar (ver ANEXO II) de Daniel Munduruku (MUNDURUKU, 1997, p. 12 - 32); contamos a lenda da lara, do Curupira, do Boto, da Vitória-régia; fizemos as canções Tche Nane, Canto Txucarramae, a melodia de Cantos do Çairé recolhida e arranjada por $\mathrm{H}$. Villa-Lobos e a criação de uma canção para a Vitória-régia; assistimos a um vídeo sobre o povo Yanomami; escutamos músicas indígenas; levamos figuras da flora e da fauna, e imagens dos personagens das lendas; construímos um barco, uma árvore, um rio, uma lara, um boto, vitórias-régias, peixinhos, dobraduras de sapos cururus; as crianças desenharam suas próprias versões dos personagens das lendas contadas; e, para apresentação final, montamos um cenário ${ }^{88}$, com esses elementos feitos pelas crianças, onde cada uma poderia reconhecer-se em parte da trajetória.

Vale ressaltar aqui, mais uma vez, que essas crianças viviam em Milão, na Itália, e possuíam pouca ou quase nenhuma informação sobre a floresta amazônica, ou informações errôneas como a de ser o pulmão do planeta, ou que os indígenas comiam gente, falavam todos a mesma língua etc. Esse laboratório foi uma oportunidade para despertarmos a curiosidade das crianças para a riqueza cultural e diversidade das populações indígenas brasileiras; para questões socioambientais, falando sobre 0 desmatamento e mostrando o respeito que esses povos possuem em relação à natureza; para a maneira como os indígenas foram dizimados na época da conquista do Brasil, e sobre como ainda lutavam para viver com dignidade.

No laboratório de 2002, nosso tema foi I canti degli uomini (Os cantos dos homens):

No laboratório deste verão, iniciamos as atividades propondo a seguinte pergunta: "O que o homem precisa para viver?"

Uma das respostas mais recorrentes - comer - direcionou nossa escolha canora e seus "contornos": jogos sobre a técnica vocal, jogos sobre os parâmetros musicais, atividades corporais, contos e dramatizações de contos, estórias e lendas pertinentes aos significados dos cantos.

88 No esboço do cenário (ver ANEXO JJ) vimos também a presença de um livro e áudio, que não consta do material guardado pela mestranda. Puxando pela memória, gravamos as canções do CD de Marluí Miranda, Ihu - Todos os cantos, e do CD de Milton Nascimento, Txaí, para tocar na sala da exposição. 
O que comemos, como comemos, onde procuramos nosso alimento, quem trabalha para que possamos comer? Tudo isso determina nossa relação com a natureza e com outros Homens.

Com os cantos de algumas culturas espalhadas por esse mundo, nos aproximamos dessas relações: cantamos o crescimento das flores (Zun Tin Lal); colocamos-nos na situação dos escravos africanos que cantavam enquanto eram obrigados a trabalhar na América do Norte (Yonder come day); caímos no meio da floresta amazônica enquanto a tribo Jabuti dançava e cantava o ritual da pesca (Tche Nane) e finalmente voltamos à Itália para vencer a guerra - se fosse o caso - com canhões cheios de macarrão. (Piatto di Maccheroni) (ver ANEXO DD, tradução nossa)

Segundo o caderno de anotações sobre essas atividades, usamos muitas atividades físicas de conscientização corporal, já que nosso tema era o Homem, as canções acima e atividades relacionadas a elas, como contos e sua dramatização, desenhos, dobraduras. Fizemos um grande cartaz com o título Razza Umana, no qual escrevemos aquilo que as crianças disseram que existe em comum em todos os seres humanos, e uma atividade onde pedimos que cada criança dissesse qual era sua cor. As respostas ficaram entre o branco e preto, mas fizemos com que elas observassem que existiam muito mais cores que essas, porque, além de peles claras, beges, morenas, rosadas, cor de chocolate, e suas diversas nuances, também havia as cores dos pelos, cabelos, olhos; enfim, ninguém tinha cores exatamente iguais aos outros, todo mundo era multicolorido: todo mundo pertencia à raça humana.

Desse laboratório, trouxemos a atividade lúdica do negro spiritual Yonder Come Day para o Coro Curumim, a qual consistia na encenação de escravos norteamericanos nas plantações de algodão ${ }^{89}$.

89 Em um dos grupos aconteceu uma situação bizarra! Estava sozinha com as crianças e, depois de ter contado sobre a maneira como os escravos africanos eram tratados, propus a atividade. Fui ao piano e, enquanto tocava e cantava as melodias da canção, as crianças encenavam livremente. De repente, ouvi uns gemidos estranhos e quando voltei os olhos em direção aos mesmos, vi um grupo de crianças fingindo açoitar um menininho. Terminei a frase musical, caminhei o mais tranquila que pude ao grupo e perguntei o que estava acontecendo. O menino nas vestes do escravo açoitado me explicou que ele havia proposto a situação porque, afinal de contas, ele era judeu e seu povo também tinha sido escravizado. Situação complicada: imagina o garoto contar a seus pais que foi açoitado durante o laboratório de música? Na intenção de limpar essa imagem, fiz uma roda de conversa com as crianças e propus uma brincadeira de roda com a canção Hinè Ma Tov, em hebraico. 


\section{ANÁLISE DE SEIS PEÇAS PARA CORO INFANTIL EXTRAÍDAS DO REPERTÓRIO MULTICULTURAL DO CORO CURUMIM}

Neste capítulo, compartilhamos o processo de análise de seis canções para coro infantil do repertório do Coro Curumim, apresentando as motivações que levaram à escolha das mesmas (considerando tanto o momento musical específico de cada grupo como o momento artístico cultural da ACC); as fontes nas quais o material sonoro e as partituras foram obtidos e informações gerais desse material; a complementação dessas informações com comentários sobre o compositor e contextualização da obra; o texto original das canções e sua tradução em português; e os aspectos musicais concernentes. Esse repertório é múltiplo quanto à origem, o estilo e a época, e foi escolhido entre as músicas que fizeram parte de concertos, apresentações e ensaios no Curumim.

Os critérios usados na seleção dessas seis canções foram os diferentes níveis de dificuldades musicais e a variedade de estilos, culturas e línguas, procurando, assim, analisar uma amostra representativa do trabalho desenvolvido em nosso coro infantil.

A característica fundamental do repertório do Curumim é a multiculturalidade, ou seja, um repertório que abarca várias culturas, com suas línguas particulares e especificidades musicais. Tal repertório foi obtido de muitas formas, envolvendo partituras encontradas em bibliotecas, outras presenteadas por grupos corais, outras recebidas em turnês da ACC com seus corais de adultos; outras fontes foram depoimentos orais de cantos tradicionais, transformados posteriormente em arranjos elaborados pela mestranda ou em parceria com o maestro Lutero.

Entre 1993 e 2003, foram ensaiadas em torno de cinquenta músicas, de compositores eruditos europeus, assim como canções latino-americanas, norteamericanas, africanas, europeias e asiáticas, de compositores ou pertencentes à tradição oral, selecionadas de acordo com as necessidades de crescimento musical, dos momentos específicos de cada grupo e das atividades performáticas.

A escolha dessa modalidade de repertório, além da finalidade artística musical, objetivava desenvolver na criança capacidades de compreensão do que lhe é diverso, 
mas igualmente humano, entendendo que todas as culturas possuem qualidades e, portanto, todos os seres são capazes de expressar algo positivo. O entendimento era de que, pelo fato de terem vivenciado a beleza e a diversidade musicais de vários povos, essas crianças pudessem crescer menos preconceituosas ou mais abertas à diversidade. A recordação emocional de um trabalho lúdico envolvendo o ensino de músicas multiculturais poderia ajudar a despertar o reconhecimento do outro - daquele que não participa dos mesmos ambientes socioculturais - como ser humano igual, com o mesmo anseio por direitos iguais e pela liberdade de expressão ${ }^{90}$.

Nossa amostragem desse repertório consta das seguintes canções:

1. Bella Ciao

2. Cockoo!

3. Das Klinget so Herrlich

4. Mekô Merewá

5. N'Kosi Sikeleli Africa

6. Tzun Tiãn Lai
Canção tradicional italiana

arranjo: Elisabet Just

Benjamim Britten

Coro dos escravos da ópera $A$ flauta mágica de W. A. Mozart

Canção tradicional dos índios Paiter Suruí de Rondônia, recolhido por Marluí Miranda

E. Sontoga e S. Majombozi

arranjo: Martinho Lutero

Canção infantil em mandarim

Recolhida e arranjada por: Elisabet Just

90 Ao longo dos anos, perdi o contato com a maioria das crianças do Curumim, mas tenho notícias de algumas: Sofia Margonari hoje é fotógrafa; Carlotta Broggio estuda na Academia de Belas Artes de Milão; Danae Rikos e Virgilio Lutero pretendem seguir a carreira de músicos e, este ano, farão o exame de admissão para o Conservatorio Giuseppe Verdi; Emma Rietti se prepara para entrar na faculdade de ciências sociais e escolheu, como tema da maturità (exame de conclusão do ensino médio e que dá acesso à universidade), "a diversidade". 
Usamos, como ferramenta de análise, o Referencial de Análise de Obras Corais (RAMOS, 2003, p. 75-96), para observar as características particulares inerentes às canções corais infantis. Para as especificidades de cada peça, tais como biografias, contexto histórico, traduções, análise harmônica etc., encontramos subsídios em diversos autores e informantes, que são referidos no corpo do texto de cada análise.

Neste trabalho se encontram as partituras ${ }^{91}$ originais dessas seis canções, usadas no Curumim, e aquelas que serviram de referência para a análise. Das partituras usadas pelo coro infantil, algumas foram escritas à mão (Das Klinget so Herlich) e ornadas com ilustrações (Mekô Merewá e N'Kosi Sikeleli Africa); outras escritas em computador, usando o programa Encore (Bella Ciao e Tzun Tiãn Lai), e, na canção Cuckoo!, usávamos a partitura editada pela Boosey \& Co, mas, em função deste estudo, cujas explicações se encontram no item em que as peças são analisadas, reeditamos as partituras de Cuckoo! e Tzun Tiãn Lai.

Assim como os outros itens, a análise dos aspectos musicais é um olhar pessoal da mestranda com base nas experiências com o Coro Curumim e os novos estudos nesta dissertação. Os termos musicais usados são de conhecimento musical elementar, definidos, quando necessário, no corpo do texto, na medida em que aparecem pela primeira vez. Para as músicas pertencentes ao sistema tonal (Bella Ciao, Cuckoo!, Das Klinget e N'Kosi sikeleli Africa) nos servimos da harmonia funcional e sua terminologia, segundo o livro do professor H. J. Koellreutter (1980), em Tzun Tiãn Lai (constituída de linhas melódicas pentatônicas sobrepostas), optamos por não classificar os raros acordes, e, em Mekô Merewá, foi analisada apenas sua linha melódica.

Antes de prosseguir, recordamos que o objeto de estudo desta dissertação se desenvolveu na Itália e, por essa razão, as canções em língua estrangeira foram transliteradas usando fonemas da língua italiana. Para que a pronúncia deste repertório

91 O uso das partituras no Coro Curumim era uma maneira de estimular a aproximação das crianças à grafia musical ocidental, mas as canções eram aprendidas de cor. Nos últimos dois anos, as crianças tinham aulas de noções da escrita musical. Não podemos falar de aulas de leitura musical, pois o tempo que dedicávamos a essa atividade era muito pequeno, não superando meia hora, e também não era constante nos ensaios. No entanto, as crianças tinham noções básicas dos elementos escritos na partitura e adoravam brincar com seus diapasões procurando notas. 
seja realizada aqui no Brasil, sugerimos, ao fim de cada análise, a audição de músicas disponíveis em CD ou na internet ${ }^{92}$.

\subsection{As Motivações, Fontes, Comentários, Textos, Traduções em Português e Aspectos Musicais de Seis Canções para Coro Infantil do Coro Curumim.}

\subsubsection{Bella Ciao}

\section{Motivações}

Em março de 2002, o diretor artístico da ACC, o maestro Martinho Lutero, iniciou sua participação no Fórum Social Mundial $(F S M)^{93}$. Naquele ano, o FSM aconteceu no Brasil, em Porto Alegre, e a ACC organizou a apresentação da Missa $L_{u b a}{ }^{94}$ com a participação de percussionistas de Burkina Faso, uma cantora muçulmana da Tunísia, Mouna Amari, com o Coral Luther King de São Paulo e vários

${ }^{92}$ Em uma das acepções da palavra pronúncia, o sotaque está englobado: "modo de articular os sons, as palavras ou frases, característico de um indivíduo ou de uma região; sotaque, acento" (HOUIAISS, 2010, 1.561). A pronúncia de línguas estrangeiras, se não foram aprendidas na infância e salvo pessoas superdotadas, carrega o sotaque de quem as fala. Nesse estudo não adentraremos em questões como defeitos da fala, ou o sotaque de uma língua comum devido a características regionais (por exemplo, os diversos sotaques que encontramos em português no Brasil: o paulista, o carioca, o mineiro, o baiano etc.). Entendendo a pronúncia como a forma oral da língua, sem excluir o sotaque individual e/ou cultural, procuramos, neste trabalho, uma aproximação com as línguas originais de maneira que os significados das palavras pudessem ser compreendidos apesar do sotaque natural. Consciente do próprio sotaque, a mestranda descreve a maneira como se pronuncia, mas também sugere referências musicais de outras interpretações das músicas analisadas.

${ }^{93}$ Fórum Social Mundial (FSM) é um evento altermundista (altermundo = busca de outro mundo possível) organizado por movimentos sociais de muitas organizações continentes, com o objetivo de elaborar alternativas para uma transformação social global. Seu slogan é "Um outro mundo é possível". Daqui em diante, usaremos a sigla FSM para nos referirmos ao evento.

${ }_{94}$ Missa Luba é uma versão da Missa Latina baseada em canções tradicionais do Congo. Foi arranjada pelo padre franciscano belga Guido Haazen, tendo sido cantada e gravada pela primeira vez em 1958 por Les Troubadours du Roi Baudouin, um coro de crianças e adolescentes de Kamina, Congo Belga. A ACC apresentou pela primeira vez seu arranjo da MIssa Luba em 2004, com a solista Miriam Makeba, numa turnê por cidades italianas. 
coros da cidade. A partir dessa experiência, criou-se o Fórum Coral Mundial (FCM ${ }^{95}$ que, entre outras atividades, projetou um encontro com diversos coros e coralistas "avulsos" para cantar peças corais em conjunto, encontro ocorrido em março de 2003 também em Porto Alegre, Brasil. Uma dessas peças foi o arranjo de Bella Ciao para quatro vozes mistas, feito pela mestranda, em parceria com o maestro; um arranjo simples e preparado para ser cantado em passeatas na Itália.

A pesquisadora estava cheia de esperanças com a ideia de que um outro mundo é possível (slogan do FSM), mas não pôde viajar ao Brasil e fazer parte in loco da manifestação, pois alguém precisava trabalhar com os coros na Itália, e Lutero e Claudia estavam em Porto Alegre. No sentido de fazer com que todos os coros italianos também participassem, construímos um arranjo para vozes femininas e outro para vozes infantis dessa peça para cantarmos enquanto o FCM acontecia no Brasil.

Com esse arranjo polifônico, foi possível dar prosseguimento ao processo de independência de vozes pelo qual o Curumim estava passando no momento.

\section{Fontes}

Bella Ciao é uma das canções tradicionais italianas mais conhecidas e, como toda música de tradição oral, existem formas variadas de cantá-la, tanto no que diz respeito à melodia como ao texto. A canção aqui analisada se inspira no arranjo cantado pelos adultos na FCM e naquele feito para coro infantil (ver ANEXO LL) pela Maestrina Susan Lovegrove Graziano ${ }^{96}$. Sendo uma canção ainda viva, presente em passeatas e manifestações políticas que aglutinam grande parte da população italiana nas ruas, procurou-se também encontrar uma forma de unificar as diferentes versões sobretudo no que diz respeito ao texto - que as próprias crianças do Curumim conheciam.

\footnotetext{
${ }_{95}$ Daqui em diante usaremos a sigla FCM para nos referirmos a essa manifestação.

${ }^{96}$ Susan Lovegrove Graziano, regente coral e educadora musical de origem inglesa, radicada na Itália.
} 


\section{Comentários}

Bella Ciao é uma famosa canção dei partigiani (em português, partisans ${ }^{97}$ ). De acordo com os estudos do etnomusicólogo Roberto Leydi, sua ascendência, no que diz respeito à melodia, se encontra num jogo de rima infantil intitulado La Me Nona L'è Vecchierella (Minha avó é velhota) (LEYDI, 1973, p. 50-53) e, no que diz respeito ao texto, refere-se à canção narrativa Fiore di Tomba (Flor de tumba) (LEYDI, 1973, p. 258-261). Sobre o nascimento da canção símbolo da resistência partigiana, segundo o estudioso, pouco se sabe:

As pesquisas que nos são conhecidas não esclarecem nem onde nem quando esta canção nasceu. O Dr. Groso, de Perúgia, afirma que a aprendeu durante a invasão em Bolonha, quando militava com as repartições regulares agregadas aos aliados. Outras testemunhas indicam a zona de Montefiorino, nos apeninos Emilianos, como local de presença desta canção durante a Resistência. (LEYDI, 1973, p. 374, tradução nossa).

A grande difusão dessa canção se dá no início dos anos sessenta, após sua gravação por Yves Montand e a série dos turbulentos espetáculos intitulados Bella Ciao, apresentados no Festival de Spoleto $^{98}$, em 1964 (LEYDI, 1973, p. 374), em que um grupo de etnomusicólogos, músicos de formação clássica e cantores do povo apresentaram canções políticas e de trabalho da tradição oral italiana, debaixo de protestos da população reacionária dos anos sessenta. Por causa desses protestos e dos conflitos que aconteceram entre segmentos de esquerda e de direita da plateia, esses espetáculos alcançaram a atenção das mídias da época e trouxeram o olhar dos italianos de diversas partes do país para essas canções tradicionais que estavam sendo esquecidas (MARINI, 2005, p. 161-174).

\footnotetext{
${ }^{97}$ Partisan é o combatente voluntário que não pertence a um exército regular e que luta por um ideal nacional, político, religioso etc. Designa mais especificamente os guerrilheiros da Resistência contra os invasores nazifascistas na França, Itália, Balcãs etc., durante a II Guerra Mundial. (ENCICLOPÉDIA LAROUSSE, 1998)

${ }^{98}$ Festival dei Due Mondi di Spoleto (Festival dos dois mundos de Spoleto) - Festival musical criado e dirigido desde 1958 por Giancarlo Menotti (Varese, 1911 - Montecarlo, 2007), compositor italiano contemporâneo que dividiu sua vida entre os Estados Unidos da América e a Itália. A ACC montou trechos de sua ópera natalina Amahl and the night visitors em 2002.
} 


\section{O texto em italiano e sua tradução em português}

\section{O Bella Ciao}

Una mattina mi son svegliato

O bella ciao, bella ciao, bella ciao, ciao, ciao

Una mattina mi son svegliato

ed ho trovato l'invasor

O partigiano portami via

O bella ciao ....

O partigiano portami via

che mi sento di morir

E se io muio da partigiano

O bella ciao ...

E se io muio da partigiano

tu mi devi seppellir

E seppellire lassù in montagna

O bella ciao ....

E seppellire lassù in montagna

sotto l'ombra di un bel fior

Tutte le genti che passeranno

O bella ciao ...

Tutte le genti che passeranno

e diranno o che bel fior

È questo il fiore del partigiano

O bella ciao ...

È questo il fiore del partigiano

morto per la libertà

\section{Oh linda, oi!}

[Em] uma manhã acordei

Oh linda, oi! Oi, linda! Oi, linda! oi, oi,oi !

[Em] uma manhã acordei

e encontrei o invasor

Ó partisan, leve-me embora

Oh linda, oi! ...

ó partisan, leve-me embora

pois me sinto morrer

E se eu morro como partisan

Oh linda, oi! ...

E se eu morro como partisan

você deve me enterrar

E enterrar lá em cima na montanha

Oh linda, oi! ...

E enterrar lá em cima na montanha

Sob a sombra de uma bela flor

Todas as pessoas que passarão [por lá]

Oh, linda, oi! ...

Todas as pessoas que passarão [por lá]

e dirão: oh, que bela flor!

É esta a flor do partisan

Oh, linda, oi! ...

É esta a flor do partisan

morto pela liberdade

(tradução nossa) 


\section{Aspectos musicais}

O arranjo (ver ANEXO MM) foi criado levando em consideração as características específicas do grupo em 2003, que era formado por em torno de dez crianças bem preparadas (algumas cantavam há cinco anos no coro, um cantava há nove anos) e experientes em cantar a várias vozes. Apesar de a voz superior trazer, na maior parte do arranjo, a melodia da canção, todas as vozes cantam ao menos um trecho dela, para dar o "gostinho" de cantar a melodia. Como dissemos, procuramos adequar as versões conhecidas das crianças às outras fontes já citadas, promovendo, assim, a participação do grupo na elaboração de parte do arranjo.

O texto é narrado em primeira pessoa, onde o partigiano comunica à sua bella situações que podem também ser encontradas na vida desses ativistas em geral: o encontro com o invasor, a fuga ${ }^{99}$ para a montanha, o companheirismo entre os partisans e a predisposição para morrer por um ideal.

No texto existe um uso poético recorrente na língua italiana, originariamente pobre em oxítonas, e muito usado em canções. As palavras invasore, morire, seppellire e fiore, foram alteradas em invasor, morir, seppellir e fior, para se adequarem à função de oxítonas exigidas para se ajustarem à melodia da canção.

Essa música é até hoje cantada em passeatas e manifestações, o que determina seu andamento próximo ao tempo de marcha, um andante, de modo que a unidade de tempo (semínima) se situa entre 92 e 96 do tempo metronômico. Inicia em anacruz de compasso quaternário, com predominância de colcheias, quando há polifonia (compassos ${ }^{100} 1,2,3,5$ e 6), e semínimas, quando o ritmo é o mesmo em todas as vozes (c. 4 e 7). Os acontecimentos rítmicos são simples, com exceção do c.4,

99 Muitos partisans se refugiavam nas montanhas. Tive o prazer de conhecer um pessoalmente, um dos cantores do Coro Terza Maggiore. que se refugiou nas montanhas de Piemonte. No texto não se fala em fuga, mas cita a montanha como local para ser enterrado. Entendemos, num sentido poético, a fuga simbolizada pela morte.

100 Daqui em diante usaremos a abreviatura c. para designar a palavra "compasso" ou seu plural. 
que pode oferecer certa dificuldade de execução para a $\operatorname{Voz} 3^{101}$, que rebate a nota fá $3^{102}$ no contratempo.

A tonalidade de fá menor foi escolhida para que a tessitura geral resultasse entre si bemol 2 e ré bemol 4 , adequada àquele grupo. É uma tessitura agradável para todas as vozes, evitando os extremos dos agudos e graves.

As linhas melódicas contam com pequenos saltos, não excedendo uma $5^{\text {a Justa }}{ }^{103}$, equilibrados entre ascendentes e descendentes, e grande presença de graus conjuntos. Nas vozes inferiores, criou-se um pedal com notas rebatidas, a nota fá 3 (c. 1, 2, 5 e 6), e com o mesmo texto ( $O$ bella ciao), presente como elemento unificador nas duas partes do arranjo $\left(\mathbf{A}^{104}=\right.$ do início à metade do c. $4 ; \mathbf{B}=$ levare do $\mathrm{C}$. 5 ao fim). A parte $\mathbf{A}$ trabalha com a região média, no sentido da frequência das notas, abrindo-se para a região aguda na sua conclusão. Essa abertura serve como preparação para a parte B que, ao seu início, explora os extremos da tessitura (graves e agudos) para voltar à região média no final.

A ideia da apresentação dos primeiros compassos da parte $\mathbf{A}$ em forma de imitação entre V. 1 e 2 , e as notas rebatidas da V. 3 foram tiradas do arranjo de Graziano. No início da parte B, a V. 3 mantém a melodia, enquanto as vozes 1 e 2 exercem a função harmônica em região mais aguda que o canto principal. Na segunda metade da parte $\mathbf{B}$, a melodia retorna à V. 1, continuando uma oitava acima até a conclusão.

A harmonia é simples, estável e tem um caminho bem definido, que leva à tensão do penúltimo compasso. Durante toda a parte $\mathbf{A}$, mantém-se a Tônica $(\mathbf{T})^{105}$. $\mathbf{A}$ parte $\mathbf{B}$ inicia com a $\mathbf{S}$ (c. 5), retorna à $\mathbf{T}$ (c. 6) e caminha para a tensão final apresentando a $\mathbf{D}$, a $\mathbf{D D}$ sem fundamental, retorna à $\mathbf{D}$ (c. 7) e conclui em $\mathbf{T}$ (c. 8).

101 Usaremos, neste capítulo, a abreviatura V. para a palavra "Voz", que indica a linha melódica de cada naipe do coro.

102 O sistema de referência que adotamos neste estudo para denominar a frequência das notas é baseado no Manuale di Teoria Musicale de Nicoletta Caselli (1993, p. 51), que, assim como outros autores, considera dó3 o dó central do piano, ou seja, uma escala de Dó Maior ascendente a partir de dó3 resulta em: dó3, ré3, mi3, fá3, sol3, lá3, si3, dó4; uma escala de Dó Maior descendente, a partir de dó3 resulta em: dó3, si2, lá2, sol2, fá2, mi2, ré2, dó2. Essa nomenclatura aparecerá sempre em itálico.

103 Usaremos, daqui em diante, a abreviatura J substituindo a palavra "Justa".

${ }^{104} \mathrm{Na}$ análise formal, são usadas letras maiúsculas para as grandes partes e minúsculas para as pequenas partes, ambas apresentadas em negrito.

${ }^{105}$ As funções harmônicas, daqui em diante, serão abreviadas e realçadas em negrito. 
Durante toda a parte A, é a V. 3 que mantém a nota fundamental, cumprindo uma função harmônica. Essa função, no início da parte $\mathbf{B}$, passa às vozes 1 e 2: na V. 1 temos saltos de terça e, na V. 2, notas rebatidas em fá 3 , em que, no c. 5 , a V. 1 possui a fundamental e a terça, e a V. 2 é a quinta do acorde, e, no c. 6, a V. 1 faz a terça e a quinta do acorde, enquanto a $\mathrm{V}$. 2 mantém a nota fundamental. Na segunda metade da parte $\mathbf{B}$, a função harmônica passa para as vozes 2 e 3 .

As dinâmicas estão geralmente relacionadas às sílabas tônicas do texto, mas existe um plano de intenções que culmina com um $f^{106}$ no início do penúltimo compasso, para decrescer ao $\mathbf{m p}$ :
A
C. 1
C. 2
C. 3
C. 4

V.

$$
m p<\mid
$$

V.2

V.1

$|m p<>\quad| m p<>\quad \mid<$

mf

I $m \boldsymbol{f}$

.1

$\mid \boldsymbol{m p}<; \boldsymbol{m f}$

$|\boldsymbol{m p}<; \boldsymbol{m f}|<$

$\mid m f<$

\section{B}

C. 5

C. 6

C. 7

C. 8

V.1

V.2

$\mid \boldsymbol{m p}<; \boldsymbol{m f}$

$|\boldsymbol{m p}<; \boldsymbol{m f}<| \boldsymbol{f}<$

I $m p$

V.1

$\mid \boldsymbol{m p}<; \boldsymbol{m f}$

$|\boldsymbol{m p}<; \boldsymbol{m f}<| \boldsymbol{f}<$

| $m p$

| $><$

$|\boldsymbol{m f}>; \boldsymbol{m f}<| \boldsymbol{f}<$

| $m p$

$\mathrm{Na}$ parte $\mathbf{B}$, encontra-se uma mudança timbrística causada pela divisão da melodia entre a voz mais grave (que canta a primeira metade da melodia uma oitava abaixo) e a mais aguda (que retorna, na segunda metade da melodia, à oitava original).

Procuramos manter, na interpretação, a naturalidade da canção tradicional sem dinâmicas exageradas e relacionando seu andamento às caminhadas em passeatas. Apenas no penúltimo compasso, quando é cantado o último verso, colocamos um rallentando.

Por ter sido realizada por um coro infantil italiano e porque esta é uma canção muito conhecida no País, não tivemos problemas relativos à pronúncia, trabalhando apenas a articulação das palavras na emissão canora. Pelo fato de esta dissertação ser feita no Brasil e esperarmos que possa servir como material de consulta para regentes

\footnotetext{
${ }^{106}$ Os sinais de dinâmica sempre serão abreviados e realçados em itálico e negrito.
} 
de coros infantis brasileiros, cabem aqui algumas sugestões quanto à pronúncia do italiano: a vogal "a" é sempre aberta, jamais anasalada; as consoantes duplas são pronunciadas fazendo a formação da primeira no interior da boca e depois pronunciando a segunda - mattina, bella, seppellir, tutte, passeranno, diranno; as consoantes finais são pronunciadas - son, ed, invasor, morir, seppellir, in, un, bel, fior, il, per - onde o " $n$ " é pronunciado levando a ponta da língua ao alto e encostando no início do palato duro, logo atrás dos dentes superiores, para logo em seguida relaxar; o "I" é pronunciado como no português dos brasileiros mais velhos, mais ou menos até a metade do sec. XX; o "r" é pronunciado com mais voltas que o "r" paulistano; o "gl" é pronunciado como nosso "lh"; o "gn" como nosso "nh"; nas palavras que começam com "s" seguidas de consoante, o "s" é mudo, portanto atenção à tendência de nós, brasileiros, colocarmos a vogal "i" antes de iniciar essas palavras (svegliato ao invés de "isvegliato").

Para melhor compreensão da pronúncia, sugerimos a audição de Bella Ciao do Gruppo Popolare e Solisti dell'Oltrepo Pavese. No que diz respeito à letra, essa é a versão mais próxima da nossa, com exceção da primeira frase, em que dizem Sta mattina mi sono alzato (YOUTUBE, 2010).

\subsubsection{Cuckoo!}

\section{Motivações}

Em 1999, o Coro Didone da ACC, regido pela mestranda e pelo maestro Martinho Lutero, iniciou a aproximação ao repertório coral de Benjamin Britten, realizando sua Missa Brevis no concerto Quattro Missa Brevis na igreja de São Marco, em Milão. No final do mesmo ano, apresentou, nos concertos natalinos, a obra do mesmo autor, Ceremony of Carols, com a participação do grupo infantil avançado na canção inicial do conjunto da obra, Hodie Christus Natus Est. 
Antes de cantar no concerto natalino, as crianças conheciam Britten por via de sua obra Variações e Fuga sobre um Tema de Purcell, na qual exemplifica os instrumentos de orquestra. A audição dessa peça foi realizada em todos os grupos infantis, dentro de uma série de atividades elaboradas para conhecer os instrumentos de orquestra, estimulando a percepção auditiva quanto ao reconhecimento de timbres e mostrando outros instrumentos possíveis de serem praticados além da voz.

A peça Cuckoo! entrou no repertório em 2000 e, em maio do mesmo ano, foi apresentada no Happening Corale com le Scuole, organizado por Susan Lovegrove Graziano no teatro San Fedele, em Milão. Nessa ocasião, o coro foi acompanhado pela mãe de um curumim, que também era pianista, e, em junho do mesmo ano, quando a reapresentamos no Salone degli Afrescchi da SU na apresentação final do curso coral, o coro foi acompanhado por Carlo Palese, professor de piano dessa instituição.

Escolhemos essa música por estar inserida no contexto de estudos realizados sobre a obra coral de Britten no grupo de estudos da ACC, por sua beleza artística e por ser adequada ao momento musical em que o coro se encontrava. É uma das poucas músicas do repertório que requer instrumento acompanhador, o piano.

\section{Fontes}

Essa peça faz parte do conjunto de músicas para vozes infantis e piano Friday Afternoons (Entardecer das Sextas-feiras), produzido entre 1933 e 1935. A partitura original foi encontrada na biblioteca do Conservatorio Giuseppe Verdi, em Milão, e sua edição, pela Boosey and Co., Ltd. B.\&H., é de 1936. 


\section{Comentários}

A música foi composta por Benjamim Britten, compositor inglês (Lowenstoft, Suffolk, 1913 - Aldeburgh, 1976), considerado a figura mais prestigiosa da música erudita inglesa do séc. XX. Dentre suas obras mais famosas, temos a ópera Peter Grimes (1945) e War Requiem (1961) para solistas, coro misto, coro infantil, orquestra e órgão. Britten dedicou grande parte de sua produção à música vocal, tanto para solistas como para formações corais, e manteve fidelidade à ideia coletiva e comunitária da música, propondo, a partir de Ceremony of Carols (para vozes femininas ou infantis e harpa, 1942), obras corais que incluem partes para executantes amadores ou jovens, como o oratório Saint Nicolas (1948) e Spring Symphony (1949) para coro infantil, solistas e órgão. São numerosas suas composições para jovens, como as músicas para teatro The little Sweep (1949) e Noye's Fludde (1957); e as Variações e fuga sobre um tema de Purcell (1946), um pequeno guia de orquestra para o público juvenil (LA GARZANTINA, 1999).

Cuckoo!, na sua versão original, apresentava uma dificuldade de execução para as crianças do grupo avançado: naquele ano, poucas crianças conseguiam alcançar, sem esforço, a nota mais aguda da V. 1 (fá 4). Se respeitássemos a partitura original e as características vocais do grupo, teríamos de dividir essas crianças (em torno de quinze) de maneira desequilibrada, ficando a maioria com a V. 2. Essa opção entraria em conflito com as intenções do compositor, pois, em sete compassos da V. 2, há indicações de dinâmicas mais fracas em relação à V. 1 (c. 7-14). Podíamos ter abaixado a tonalidade em uma terça menor para que todas as crianças pudessem cantar, mas assim a peça perderia o timbre das regiões agudas e a imitação do cuco ficaria muito grave e não seria mais uma imitação. Podíamos também ter escolhido outra música do livro Fryday Afternoons, mas era começo de março, estávamos saindo do inverno fustigante, a temperatura aumentando a cada dia, os casacos ensacados, o retorno do canto dos passarinhos, o rumor das cigarras, o verdinho das folhas nascendo, a vida chegando outra vez... Aquela canção era perfeita naquele momento! 
A mestranda realizou uma adaptação da obra, dividindo a melodia (1st voice) entre três naipes: enquanto uma voz cantava parte da melodia, as outras se revezavam no ostinato que imita o cuco (2nd voice).

\section{O texto em inglês e sua tradução em português}

\section{Cuckoo!}

What do you do?

"In April I open my bill;

In May I sing night and day;

In June I change my tune:

In July far far I fly;

In August away I must."

\section{Cuco!}

O que você faz?

"Em abril, abro o bico

Em maio, canto noite e dia

Em junho, mudo meu tom [meu canto]

Em julho, voo longe, longe

Em agosto preciso ir embora."

(tradução nossa)

\section{Aspectos Musicais}

O texto começa com uma pergunta ao cuco $^{107}$ e ele responde o que faz em cada mês. Os meses citados compreendem a primavera e o verão no hemisfério norte, estações em que o dia é mais longo, o frio do inverno foi-se embora e as árvores ainda não ficaram nuas com a chegada do outono. O texto pode ser compreendido como metáfora das fases da vida: nascimento, infância, adolescência, fase adulta e morte.

$\mathrm{Na}$ partitura original, o texto é atribuído a Jane Taylor, poetisa inglesa do começo do séc.XX, e os versos foram citados no livro Tom Tiddler's Ground de Walter

\footnotetext{
107 O cuco é um pássaro muito comum na Europa e seu canto parece uma sequência de terça maior descendente na região aguda. O canto do cuco anuncia a chegada da primavera. Ouve-se seu canto entre os meses de abril e junho.
} 
de la Mare. Existem informações de que esses versos fazem parte do saber popular, as chamadas children nursery's rhimes (rimas infantis para embalar, de acalanto) (NURSERY RHYME, 200?).

Aqui serão apresentadas duas partituras, a original editada pela Boosey \& Co (ver ANEXO NN) e a adaptação para o Curumim (ver ANEXO OO). Naquele momento, o coro era composto por em torno de quinze crianças. Enquanto uma pequena parte alcançava o fá 4 sem dificuldade, outra pequena parte tinha dificuldades em atingir o $\mathrm{mi}$ bemol 4, já que a maioria das crianças possuía vozes graves ou ainda não havia desenvolvido sua tessitura aguda. Portanto, fizemos as seguintes adaptações:

1. Para manter os $p p$ e $p p p$ escritos na partitura original, a imitação do cuco foi realizada por todos os naipes, que se revezavam no ostinato quando não tinham a melodia da 1st voice, onde o padrão é cantar como cuco um compasso sim, um compasso não.

2. Para que todas as crianças pudessem cantar a melodia de acordo com sua tessitura, a 1st voice foi dividida entre os naipes: V. 1 = c. 3 a 5 e 15 a 20; V. $2=$ c. $11 \mathrm{a} 14 ; \mathrm{V} .3=$ c. 7 a 10.

Observamos mudanças timbrísticas em relação à vontade do compositor devido à divisão da melodia em três naipes, ou seja, a melodia foi "colorida" por três naipes diferentes, de acordo com suas respectivas características, ao invés de manter um único naipe como proposto pelo compositor. Quanto às outras indicações musicais (frequência, dinâmicas e ritmos), foram mantidas conforme escritas na partitura original.

No início da partitura, encontramos a palavra quietly, assim definindo um andamento de caráter tranquilo. Adotamos como unidade de tempo a semínima pontuada perto de 52 (décimos de segundo), sem alterações no decorrer da peça. A figura rítmica predominante é a colcheia em levare para semínima ou semínima pontuada. Quando essa presença se dá no ostinato (os "Cuckoo" em terças maiores descendentes), a semínima cai no segundo tempo do compasso; quando acontece na melodia, a semínima pontuada cai no primeiro tempo. 
A figura rítmica do ostinato se assemelha às batidas do coração, a um impulso vital que encontramos do início ao fim da obra, e pode ser relacionada à metáfora das fases da vida encontrada no texto. A mão direita do piano acompanha essa figuração rítmica do ostinato e, na mão esquerda, predomina a figura que representa a unidade de compasso, a mínima pontuada.

A peça é límpida, sem complicações rítmicas, sugerindo leveza na execução.

A tessitura geral das vozes se encontra entre o fá 3 e o fá 4 : V. 1 - de fá 3 a fá 4; V. 2 de fá 3 a mi bemol 4; V. 3 de fá 3 a dó 3 . O piano se estende entre o lá bemol 0 e o fá 4.

A alternância entre graus conjuntos e saltos, que não excedem uma $5^{\text {a }} \mathrm{J}$, forma uma melodia fácil de ser cantada sobre o ostinato que imita o canto do cuco.

Inicia e termina em Lá bemol Maior, mas, no corpo da peça (c.7 a 19), aparece sete vezes a $\operatorname{Tr}$ (acorde de fá menor). Nesses compassos, acontece uma curiosa linha descendente no baixo da mão esquerda do piano - a sequência de notas fá (c. 7), mi b

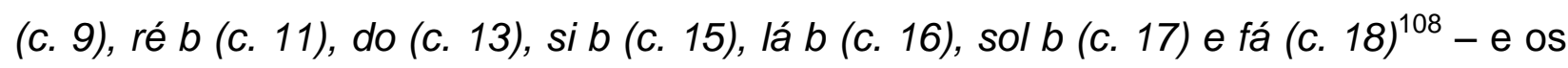
acordes são construídos com base nessa série. É nesses compassos também, com exceção da última palavra (c. 20), que o cuco conta sua história.

A afirmação da tonalidade em Lá bemol Maior na introdução (c. 1 a 6) e na coda (c. 21 a 25) está em harmonia com a narrativa do cuco baseada em sua Tr, fá menor $^{109}$, e a escala descendente na linha do baixo do piano, que nos remete a um clima idílico, de suspensão.

108 Essa sequência corresponde ao modo grego primordial, Dórico, que emprega, de maneira descendente, a sequência de notas naturais de mi a mi, onde temos a mesma relação intervalar da linha melódica a que nos referimos: Tom, Tom, meio tom, TOM, TOM, TOM, meio tom (ANDRADE, 1980, p. 27). A escala grega citada se difere da homônima dos modos eclesiásticos, onde o nome Dórico é dado a uma escala ascendente que compreende os intervalos da sequência de notas naturais que vão de ré a ré: TOM, semi tom, TOM, TOM, TOM, semi tom, TOM. Sabemos que o modo dórico era muito importante para os gregos, considerado "nacional por excelência e que serviu de base às especulações teóricas" (ANDRADE, 1980, p. 28), usado também, como se sabe, para harmonizar o ser humano. É possível que Britten tenha usado essa sequência na linha melódica propositalmente, no sentido de resgatar o significado grego da escala dórica.

109 Nossa opção em não definir como modulação para a fá menor no discurso dos compassos 7 a 20, decorre de uma visão subjetiva da obra. Para a pesquisadora, essa canção é uma metáfora da própria vida, na qual a vida eterna é simbolizada pela tonalidade de Lá bemol Maior, e a vida terrestre, aquela narrada pelo cuco, está subordinada à mesma e representada pelos acordes relativos à tonalidade de Lá b $M$, sobretudo sua tônica relativa, fá menor. 
Os sinais de dinâmica estão relacionados com o sentido do texto e com as alturas da melodia, quando alguns movimentos melódicos ascendentes recebem o reforço do sinal de crescendo (c. 3, 12, 14 e 16). A peça inicia em pp, mantido por todas as vozes durante os seis primeiros compassos (a introdução), excetuando o pequeno crescendo na frase inicial da melodia, quando o narrador pergunta ao cuco o que ele faz. Daí em diante, inicia-se um crescendo de dinâmica que caminha para o $f$ no c. 17, construído a cada dois versos (ou a cada frase musical). No c. 18 temos um diminuendo até o $\boldsymbol{p}$ do c. 20, um outro diminuendo no c.21 e um pp nos c. 22 e 23, que preparam o retorno $\mathrm{Da}$ Capo. No penúltimo compasso, ao terminar a obra, existe um ppp com decrescendo no último compasso.

O ostinato das vozes e o piano apresentam uma dinâmica mais suave que a melodia principal (no c. 7 a melodia tem $\boldsymbol{p}$, enquanto os ostinatos e o piano têm pp), e crescem de maneira paralela até o c. 15. Dali em diante, vozes e piano têm a mesma dinâmica. No levare do c. 11, para a melodia, e na cabeça do mesmo compasso, existe o sinal poco più $f$ para as vozes e para o piano.

A obra foi dividida em introdução (c. 1 a 6); discurso (c. 7 a 21); e coda (c. 21 a 25).

$\mathrm{Na}$ introdução encontramos o "som do cuco" e a pergunta do narrador, acompanhados por notas escritas na clave de sol, tocadas pela mão direita no piano, todos em $\boldsymbol{p p}$, o que nos sugere sons suaves nesse início.

O discurso é dividido em três partes (frases musicais) todas iniciando em levare: $\mathbf{a}=$ c. 7 a $10 ; \mathbf{b}=$ c. 11 a $14 ; \mathbf{c}=$ c. 15 a 21 .

A frase a inicia com a melodia em alturas médias e em $\boldsymbol{p}$, acompanhada pelo ostinato em $p p$ e pelo início da presença das notas graves do piano em battere (na cabeça do $1^{\circ}$ tempo) sustentadas por dois compassos pelo pedal, mas em $\boldsymbol{p p}$, o que indica a manutenção da delicadeza da introdução para todas as vozes. A melodia é exatamente igual para os dois versos cantados nessa parte.

$\mathrm{Na}$ frase $\mathbf{b}$, a melodia caminha para uma extensão mais aguda e, assim como todas as outras vozes e o acompanhamento, recebe a indicação dinâmica poco più $f$. O piano continua a apresentar as notas graves em battere (na cabeça dos primeiros tempos) e sustentadas por dois compassos pelo pedal, como se chegasse atrasado 
para marcar o início de cada novo verso. A melodia sofre pequena alteração rítmica na sua repetição, para se adequar ao quarto verso da narrativa do cuco.

$\mathrm{Na}$ frase c, a melodia canta apenas um verso e chega à sua extensão mais aguda, com o timbre mais claro e aberto, e com a dinâmica mais forte da música, para decrescer ao $\boldsymbol{p}$ na última palavra. O piano e o ostinato "cuckoo" acompanham a mesma dinâmica da melodia.

O acompanhamento do piano, até agora mantendo os acordes da mão esquerda por dois compassos, apresenta um acelerando de intenção ao mudar os acordes da mão esquerda em cada compasso (c. 15 a 18), no momento em que o Cuco acena sua partida. Podemos interpretar a aceleração desses acordes como metáfora da sensação temporal que o ser humano percebe no final da vida, quando o tempo voa...

Essa terceira frase do discurso do cuco é a mais densa da peça onde, além do que foi dito acima, aparece a dominante menor (c. 17) para desestabilizar o discurso harmônico.

$\mathrm{Na}$ coda, a melodia está ausente e assemelha-se aos dois primeiros compassos da introdução, não fosse o acompanhamento do piano com notas graves e mantidas por dois compassos. Na primeira vez que aparece, serve como preparação para o Da Capo e possui apenas dois compassos. Ao final da peça, são acrescentados outros dois compassos em ppp e diminuendo, em que o acompanhamento do piano possui as notas mais agudas da peça.

A música é intimamente relacionada com o texto, e quase todos os parâmetros sonoros caminham para o momento de maior dramaticidade dele, nos c. 15, 16, 17 e 18: é aí que o cuco diz que vai embora. A dinâmica atinge o $f$ (c. 17), que vem construindo desde o início da peça e a melodia atinge sua nota mais aguda (c.16 e 17 fá 4), apresentando um novo timbre. Apenas o ritmo da peça não sofre alterações nesse momento, mas é também aqui que aparece a dominante menor (c. 17), realçada pela presença do sol bemol 1 na mão esquerda do piano.

A pronúncia do texto respeita as normas do inglês britânico, fácil de ser encontrada aqui no Brasil. Sugerimos a interpretação de um coro infantil de Bruxelas, The Monnaie Children's Choir, regido por Denis Menier (YOUTUBE, maio 2012). 


\subsubsection{Das Klinget so Herrlich}

\section{Motivações}

Essa canção pertence à ópera "A flauta mágica", escrita por Wolfgang Amadeus Mozart (Salisburgo 1756 - Viena 1791) em seu último ano de vida. Essa ópera está presente nos palcos do mundo inteiro, na televisão, no cinema, em versões para adultos e crianças; já foi levada ao cinema por Ingmar Bergman nos anos 70 e, nos anos 80, foi adaptada também para o cinema por Kenneth Branagh, numa versão livre em inglês, que transporta a obra para o período da I Guerra; foi recriada por Peter Brook, neste século, num cenário clean feito apenas de bambus; e por Goethe, que "era maçom, e tinha tal estima pela obra, nisto incluído o libreto, que chegou a sonhar, por um momento, em escrever uma continuação [de A Flauta Mágica]" (CHAILLEY, 1994, p. $19)^{110}$.

O incontestável valor artístico e os ideais embutidos na obra, como o humanismo e a fraternidade, estão em perfeita sintonia com as intenções sociais da ACC e, por extensão, com o Curumim: "Desde sua estreia, a obra tem sido associada a ideais maçônicos bem concretos: o humanismo, a fraternidade e a ordenação da vida segundo etapas de iniciação." (Folha de São Paulo, 2011, p. 11).

Em 2003, surge a oportunidade concreta de realizar a canção: o concerto principal do Coro Terza Maggiore da ACC teve como tema central a ópera. Para aquele concerto, preparamos partes da ópera Se sa minga, de Carlos Gomes, em dialeto milanês, trechos da ópera Treemonisha de Scott Joplin, árias de óperas de compositores diversos, e duas partes de A Flauta Mágica de Mozart: Das Klinget so Herrlich, para coro a três vozes mistas, e Könnte jeder brave Mann, para dois solistas

110 "Esse projeto chegou a ser iniciado, dele existindo um fragmento publicado em 1802. Além disso, o cunhado de Goethe, Vulpius, preparou uma nova versão do libreto, levada ao palco em Weimar, em 1794. A tradução francesa da continuação de Goethe foi publicada em 1974 no [livro] Goethe francomaçom de Roland Guy." (CHAILLEY, 1994, p. 19). 
(Davide Rocca ${ }^{111}$ e a maestrina) e acompanhamento de piano. O concerto foi realizado no auditório da SU, em 24 de maio de 2003, em Milão, com o Coro Terza Maggiore, o Coro 1492 , solistas ${ }^{112}$, pianista e com a participação das crianças do Curumim.

Essa era mais uma oportunidade para as crianças participarem de um concerto ao lado de coros de adultos e de músicos; mais uma vez se realizava a rica operação cultural da ACC de misturar amadores e profissionais, de colocar, em um mesmo espetáculo, obras conhecidas e desconhecidas do público. Fazer música com profissionais da área, ou com aqueles que conseguem emocionar, prender a atenção das pessoas com sua música, é um aprendizado sensível que transforma emoções, percepções e fazeres musicais posteriores a essa experiência.

A canção, escrita pelo compositor para coro de três vozes masculinas, o coro dos escravos, com introdução do glockenspiel ${ }^{113}$, é adequada às vozes infantis (quando transposta uma oitava acima), tanto no que diz respeito à tessitura vocal como nos significados das palavras e caráter lúdico da peça ${ }^{114}$.

\section{Fontes}

A adaptação para vozes infantis que usamos foi baseada na partitura da ópera A flauta Mágica, de W.A.Mozart, publicada pela Edizioni Ricordi ${ }^{115}$.

111 Davide Rocca é um barítono italiano versátil, capaz de realizar, com maestria, um vasto repertório que vai da música antiga à contemporânea. Em seu currículo, encontramos uma formação musical de base sólida (diplomado em piano e canto - com a soprano G Ravazzi - em Roma) e diversos cursos de aperfeiçoamento, entre eles, o de música barroca com Emma Kirky e E. Tubb, em Dirkington, Inglaterra.

112 Os solistas, com exceção de Davide Rocca, eram integrantes de um ou mais coros da ACC.

113 Glockenspiel, em português, carrilhão - "instrumento idiófono de percussão, constituído de uma série de pequenas lastras de alumínio entoadas em escala diatônica ou cromática: o som é metálico e bem agudo. Em italiano, se chama 'campanelli' (sininhos). Foi empregado por Mozart em A Flauta Mágica, em 1791, para representar o instrumento de Papageno." (LA GARZANTINA, 2002, p. 351, tradução nossa).

114 Usar essa peça uma oitava acima com coros infantis é comum, e encontramos diversos exemplos na internet. Compartilhamos um desses exemplos, a interpretação do coro Escolania Escorial (YOUTUBE, fev. 2010), regido por Lorenzo Ramos, que possui uma pronúncia particular do alemão, devido ao forte sotaque espanhol, o que não subtrai a beleza dessa montagem.

115 A partitura de referência para esse arranjo não viajou com a mestranda para o Brasil. Neste estudo, usamos as partituras da ópera A Flauta Mágica disponíveis na biblioteca da ECA-USP. 


\section{Comentários}

Analisaremos aqui apenas a canção Das Klinget so Herrlich e seu contexto ao interno da obra. A canção foi adaptada para as vozes infantis, subindo todas as vozes de uma $8^{a} \mathrm{~J}$ em relação à partitura original. Para esse estudo, será analisada a partitura a três vozes infantis, escrita a mão pela maestrina.

As crianças que cantaram essa canção faziam parte do grupo que ensaiava na Libreria Claudiana e todas, sem exceção, se não a conheciam inteira, já tinham pelo menos ouvido partes de $A$ flauta mágica. Todas conheciam a melodia principal de Das Klinget, o que trouxe certa dificuldade em ensinar as outras duas vozes. Cabe aqui ressaltar que essas atividades foram realizadas na Itália, berço da ópera, onde faz parte do saber comum cantarolar trechos de árias e melodias operísticas, assim como aqui no Brasil cantarolamos canções da MPB.

\section{O texto em alemão e sua tradução em português}

\section{Das Klinget so Herrlich}

Das Klinget so Herrlich

Das Klinget so Schön!

Larala, larala!

Nie hab ich so etwas

Gehört und Gesehen!

Larala, larala!

\section{Que música tão magnífica ${ }^{116}$}

Que música tão magnífica, que música tão bela!

Laralá, laralá!

Nunca tinha visto nem ouvido

coisa semelhante!

Laralá, laralá!

(FOLHA DE SÃO PAULO, 2011, p.41)

116 A tradução em português difere daquela usada com as crianças do Curumim: "Ma che meravigliosi suoni, quanto sono belli! Larala... Non ho mai visto o sentito roba uguale! Larala" (Mas que sons maravilhosos, como são belos! / Nunca vi ou ouvi coisa igual!). 


\section{Aspectos musicais}

Aqui analisamos a partitura ${ }^{117}$ usada no Curumim, adaptada para vozes infantis e transposta uma $8^{\mathrm{a}}$ acima (ver ANEXO PP).

O texto da canção, assim como todo o libreto, foi escrito por Emanuel Schikaneder"118 (1751 - 1812), "um autêntico homem de teatro, além de ser um inteligente empresário" (LANDON, 1990, p. 141), que também era ator e cantor, amigo de Mozart, e atuou como Papageno na primeira montagem de A Flauta Mágica. A canção Das Klinget so Herrlich, cantado por Monostatos e por seus escravos, descreve o momento em que Papageno está fugindo com Pamina ao encontro de Tamino. Mas Monostatos, o mouro, uma espécie de capataz de Sarastro, chama seus escravos para prenderem os fugitivos. Ao chegarem com suas correntes, ferros e cordas, Papageno toca o carrilhão e seus sons enfeitiçam Monostatos e seus escravos, fazendo-os cantar esta canção e dançar.

É uma canção simples a três vozes, fácil de ser memorizada e não apresentou dificuldades melódicas nem rítmicas para o grupo com que trabalhamos. A análise desta peça traz a compreensão do porquê de ser uma peça simples e fácil de ser montada, como veremos a seguir.

Sua tessitura geral, adequada a coros infantis, está entre o dó 3 e o sol 4: V. 1 - sol 3 a sol 4; V. 2 - fá 3 a mi 4; V. 3 - do 3 a sol 3.

Os dezesseis compassos da canção em forma binária podem ser divididos em duas grandes partes (A - c. 1 a 8 ; $\mathbf{B}$ - c. 9 a 16), que por sua vez se subdividem em duas pequenas partes $(\mathbf{A}=\mathbf{a}-\text { c. } 1 \text { a } 4 \text {; } \mathbf{b}-\text { c. } 5 \text { a } 8 ; \mathbf{B}=\mathbf{c}-\text { c. } 9 \text { a } 12 ; \mathbf{b} \text { '- c. } 13 \text { a } 16)^{119}$.

As V. 1 e 2 caminham em terças paralelas durante toda a música, com exceção dos três finais de frase de $\mathbf{b}, \mathbf{c}$ e ' b'. Essas vozes possuem a predominância de graus

117 Na partitura do Coro Curumim está escrito o apelido da canção, Das Klinget, mas seu nome completo é Das Klinget so Herrlich, como vem designado no índice da partitura da ópera.

118 O libreto é atribuído à Shikaneder, mas existem estudos que levantam a hipótese de que o texto de $A$ Flauta Mágica foi escrito por mais pessoas, incluindo o próprio Mozart (CHAILLEY, 1994, p. 23-30). Para Landon (1990, p. 129), esse problema tem sido discutido por quase duzentos sem provas evidentes.

119 Na partitura anexada, que foi usada com o Coro Curumim, não consta o sinal de repetição da parte B, mas a canção foi realizada com a repetição dessa segunda parte, como escrita na partitura original. 
conjuntos e notas repetidas em suas respectivas melodias (com exceção do antepenúltimo compasso que aparece um salto de quinta descendente paralelo nas $\mathrm{V}$. 1 e 2). A V. 3 tem a predominância de notas repetidas e saltos de 4 ấ e $5^{\mathrm{a}} \mathrm{J}$, além de exercer a função de baixo harmônico, geralmente cantando a nota fundamental do acorde. Observa-se o movimento contrário da melodia da V. 3 em relação às vozes agudas durante toda a peça, cessando apenas quando se mantém o pedal harmônico na nota ré durante a parte $\mathbf{c}$.

Nessa canção homorrítmica, são usadas apenas três figuras de notas (colcheias, semínimas e mínimas), além das pausas de semínimas e semínimas pontuadas $^{120}$. As figuras rítmicas, iguais nos quatro compassos das partes a e c, começam em levare (de duas colcheias ou de semínima) e são truncadas no terceiro tempo pela pausa de semínima. Nas partes b e b', que também reproduzem a mesma figuração rítmica entre si, onde o texto é "laralá”, as pausas estão ausentes, o que deixa implícito que essas partes são em legato. As semínimas pontuadas trazem movimento às melodias: a primeira semínima pontuada conduz ao extremo da tessitura da parte $\mathbf{b}$ (V. 3 dó 3 e V. 1 mi 4 - c. 6) e b' (V. 3 dó 3 e V. 1 sol 4 - c. 14) e a segunda serve para concluir ambas as partes em uníssono. A semínima pontuada, que aparece pela primeira vez no c. 11, como levare para conclusão da parte c, serve como elemento unificador entre as partes c e b'.

Não existem sinais de dinâmica nessa parte coral, mas a canção é precedida pelos sons suaves do carrilhão (com a indicação $\boldsymbol{p}$ ), que além de dar a tonalidade, 0 andamento da canção e evocar a infância pela semelhança sonora entre o glockenspiel $^{121}$ e as caixinhas de música ${ }^{122}$, provoca a emissão vocal de sons em $\boldsymbol{m p}$. Os crescendo e decrescendo da canção são suaves e acompanham a tendência

${ }^{120}$ Com exceção da última nota, nas três vozes, uma mínima pontuada que compensa o levare do início.

121 Originariamente, o instrumento de Papageno seria um instrumento de madeira: "O libreto original denomina-o "brinquedo de madeira" (hölzernes Gelächter), mas a partitura transforma esta expressão em stromento d'acciajo (instrumento de aço), de acordo com o que entendemos hoje sob a mesma denominação. O que parece é que a ideia de "brinquedo" tenha sido determinante, por oposição à Flauta mágica, e que os nossos glockenspiels de orquestra com teclado, muito aperfeiçoados, tiram alguma coisa da rusticidade desejada para um instrumento que deve ser tocado em pleno palco, e não, certamente, no fosso." (CHAILLEY, 1994, p. 113).

122 Nos ensaios, tocava a parte do carrilhão ao piano para introduzir a canção, e perguntava a eles com o que se pareciam aqueles sons agudos. Muitos falavam em sininhos, outros em caixinha de música. 
natural das vozes serem mais fortes nas frequências agudas e mais fracas nas frequências graves.

O andamento usado foi o allegro, com a semínima em torno de 160. Não existe sinal de andamento na partitura original, mas existe a indicação de que os personagens cantam e dançam como se fosse uma marcha ${ }^{123}$. A manutenção da regência em quatro, de acordo com a fórmula de compasso da partitura original e da adaptação que usamos, confere à peça uma marcação de marcha e está de acordo com a indicação escrita do caráter desta peça. Sabemos que, nessa parte, os personagens cantam e dançam, mas é uma dança "dura" e desajeitada, feita pelos vilões da história, que são adocicados pela melodia do carrilhão. Excetuando os c. 6 e 14 (partes b e b', respectivamente), onde aparece a função de subdominante relativa (Sr), são usadas somente funções harmônicas principais na tonalidade de Sol Maior em toda a peça, $\mathbf{T}$, $\mathbf{S}$ e $\mathbf{D}$, geralmente em suas posições fundamentais. Enquanto as partes $\mathbf{b}$ e b' apresentam quase a mesma sequência harmônica (excetuando os compassos 6 e 14): $\mathbf{b}=\mathbf{T}$ - Sr/3 S Sr/3 - T/5 D - T; b' = T - S Sr/3 - T/5 D - T, a parte c é quase um espelho harmônico da parte $\mathbf{a}: \mathbf{a}=\mathbf{T}-\mathbf{D} 7-\mathbf{D}-\mathbf{T} ; \mathbf{C}=\mathbf{D}-\mathbf{T} / \mathbf{5}-\mathbf{D} \mathbf{7}-\mathbf{T}$. Durante a parte $\mathbf{c}$ temos um pedal harmônico na nota ré 3, mantido pela $\mathrm{V}$. 3, que vai para a nota fundamental da T no último compasso dessa parte.

As sílabas tônicas do texto caem sempre no primeiro tempo, ou seja, no tempo mais forte dos compassos, concorde com a pronúncia em alemão ${ }^{124}$.

A tessitura adequada às vozes infantis, a condução melódica predominantemente em graus conjuntos das vozes superiores que caminham em terças paralelas, o desenho melódico da voz inferior que geralmente caminha em direção contrária às vozes superiores (de acordo com o que aprendemos nas aulas de contraponto sobre a condução das vozes!), a predominância das funções harmônicas principais (nesses dezesseis compassos, oito estão na $\mathbf{T}$, quatro na $\mathbf{D}$, dois possuem tanto $\mathbf{T}$ quanto $\mathbf{D}$ e dois se dividem entre $\mathbf{S}$ e $\mathbf{S r}$ ) que deixa clara a tonalidade de Sol

${ }^{123} \mathrm{Na}$ partitura original, antes de iniciar os sons do carrilhão, está escrito "Papageno spielt auf dem Glockenspiel. Sogleich tanzen und singen Monostatos und die Skaven, und gehen unter dem Gesange marschmässig ab" (Papageno toca o carrilhão. Faz dançar e cantar Monostatos e seus escravos sob uma canção em marcha marcial, tradução nossa).

124 Adotamos a nossa pronúncia do alemão com as crianças do Curumim, por ser um idioma familiar para a mestranda. 
Maior e apresenta pouca variação harmônica, a figuração rítmica repetitiva, e, finalmente, a homorritmia são fatos musicais que tornam a peça simples e fácil de ser cantada pelas crianças e montada pelo regente.

Os aspectos que precisaram de maior cuidado e atenção foram a pronúncia do texto, o trabalho com a manutenção da respiração nas partes b e b' ${ }^{, 25}$, as notas agudas da V. 1 e V. 2 nos compassos 6 e 14 e a afinação da V. 3 devido aos saltos de 4⿳亠丷a s e $5^{\mathrm{a}} \mathrm{s}$.

Para ouvir a pronúncia em alemão, sugerimos esta interpretação de Sir Colin Davis a partir do minuto 1:48 (YOUTUBE, set. 2009).

\subsubsection{Mekô Merewá}

\section{Motivações}

O interesse por cantos indígenas brasileiros faz parte da ACC desde seu nascimento. Em dezembro de 1991, foi apresentado o primeiro concerto da Associazione Culturale Cantosospeso depois de oficializada em estatuto:

Kraò é um espetáculo coral que coloca em evidência a tradição da música coral extra europeia, geralmente desconhecida na Itália, com um panorama que percorre a experiência da música africana, negro-spiritual, músicas populares brasileiras, incluindo aquela dos índios da Amazônia. É de uma tribo amazônica que este espetáculo recebe seu nome: Kraò. As músicas, as vozes, são seguidas e circundadas de imagens, que não descrevem 0 som, mas completam o âmbito das percepções: ligar o ouvir ao ver, por sugestão, por insinuação das impressões ao invés de definições. O concerto se desenvolve em cena, progride em disposições mutáveis, como se quisesse descrever, no espaço, o movimento do tempo musical: o agitar-se da vida. A vontade do coro é a de apresentar, através de músicas diferentes, diferentes modos de pensar e de viver a música, e, paralelamente, a vida. (Programa de Sala do espetáculo KRAOे - Sconcerto Corale in Movimento, 14 de dezembro de 1991, Teatro delle Erbe, Milão, tradução nossa).

125 Para as crianças que não conseguiram fazer os quatro compassos das partes b e b' ligados, sugerimos uma respiração entre o $3^{\circ}$ e o $4^{\circ}$ tempos dos compassos 6 e 14. 
As músicas indígenas brasileiras continuaram a fazer parte do repertório dos coros da ACC, e o próprio nome do coro infantil objeto de nosso estudo, o Curumim, é um nome em língua tupi-guarani, portanto, se autojustifica a inserção de canções da cultura indígena do Brasil no repertório musical do nosso coro.

Essa peça foi realizada pela primeira vez em 2000, no laboratório de verão na SU, em Milão, cujo tema foi La foresta Amazzonica.

Nessas férias, em torno de cem crianças participaram dos nossos laboratórios musicais e, como relatamos no capítulo I, item 1.2.2., as atividades musicais foram apoiadas por atividades lúdicas, tais como encenações, histórias contadas, jogos, brincadeiras, construção de cenários, atividades de artes plásticas, apresentações de vídeo e músicas. Procuramos oferecer um panorama geral e elementos que despertassem a curiosidade das crianças italianas pelo indígena do Brasil, seus costumes, seus espaços.

Mekô Merewá foi uma das peças indígenas escolhidas nesse curso de férias por causa de sua pequena tessitura e melodia simples, que ajudaram na memorização rápida e facilitaram a execução feita por crianças, na grande maioria, inexperientes em canto.

A canção foi absorvida pelo Coro Curumim em seu grupo de iniciantes dentro da atividade lúdica $A$ Onça e o Jabuti, relatada no capítulo III, item 3.4.3.

\section{Fontes}

Nossas referências para essa canção foram a partitura do arranjo feito por Marluí Miranda (ver ANEXO QQ), as informações contidas em seu livro IHU - Todos os sons (MIRANDA, 1997) e a gravação do CD homônimo.

A partitura usada no laboratório, realizada pela regente (ver ANEXO RR), traz a figura de uma onça extraída do livro de Daniel Munduruku, Histórias de índio, (MUNDURUKU, 1997, p. 10), com ilustrações feitas por Laurabeatriz, e transcreve a 
linha melódica do tema do arranjo feito por Marluí Miranda. A letra da canção na partitura está transliterada para fonemas da língua italiana ${ }^{126}$.

\section{Comentários}

É uma canção ligada à espiritualidade do povo Paiter Suruí ${ }^{127}$, de Rondônia, a que tivemos acesso graças a Marluí Miranda, que a recolheu com Uratana Suruí, entre 1978 e 1981 (MIRANDA, 1997, p. 22).

Miranda descreve uma situação na qual a canção está inserida. Uma menina da tribo estava muito doente, à beira da morte. Então, a comunidade tentou curá-la com a ajuda dos espíritos que viriam naquela noite para um ritual chamado "Hoiete". Nesse ritual-festa, preparado durante o dia, iniciado ao entardecer e que atravessou a noite, estavam presentes cantos e danças em roda. Um círculo sagrado foi formado por homens da tribo e todos os pajés, e as mulheres também podiam participar. Todos na intenção de curar a indiazinha. Mekô Merewá foi entoada no começo pelo pajé Cassitermaga, de forma bem tranquila, enquanto expirava a fumaça de seu cigarro de palha, para que depois os jovens formassem o círculo e iniciassem a marcação do tempo com os pés na terra (MIRANDA, 1997, p. 151 a 154).

126 Na partitura aqui analisada, consta uma palavra diferente, da cantada no CD de Marluí Miranda e do grupo Beijo, no c. 8: bikenaiá. Usaremos nesta análise a palavra bikuerá.

127 "Os Suruí, como muitos índios, são um povo de cantores. A toda hora, de dia ou de noite, alguém entoa uma cantiga. Há pessoas que cantam melhor ou pior e os que sabem inventar mais - mas os Suruí acham estranho que na nossa sociedade, só alguns saibam fazer música ou sejam cantores. As canções Suruí (não as músicas rituais) tem [sic] dono e costumam ser cantadas só pelo autor. Não se canta [sic] , parece, as canções de quem já morreu.

A música Suruí tem muitas variedades - de melodia, de conteúdo e de finalidade. De grande importância são as cantigas de cerimônias de cura e pajelança.

O pajé, tomado por espíritos, as canta individualmente, ao curar doentes, assoprando e chupando seu corpo. Aprende cantos em meses de reclusão, diretamente, dizem os Suruí, do espírito criador, o demiurgo, com ajuda de algum pajé experimentado. Mas não só ele sabe essas cantigas e sim toda a tribo, embora a linguagem pareça arcaica, distinta da usual.

Há por exemplo, cantos da Lua, espírito cujo nome não pode ser pronunciado por mulheres que a designam por outra palavra. Há o grilo; o Pássaro Vermelho por quem todas as mulheres se apaixonam; há um ser que usa um cocar tão lindo que até as folhas das árvores suspendem sua queda para olhar - e centenas de outros, desfiando seu enredo, seres das águas, do céu e do mato." (MINDLIN apud MIRANDA, 1987, pág. 144). 
Comparando a partitura de Miranda e a música cantada no $C D$, encontramos um problema: existem diferenças na letra entre a partitura e o CD. Aproveitamos a oportunidade dessa dissertação para nos aproximarmos à maneira como a língua do povo Paiter Suruí é pronunciada por quem a recolheu, Marluí Miranda, e o grupo Beijo, que canta essa música no CD sob sua orientação.

\section{O texto tupi-monde e seu significado em português}

Miranda descreve as dificuldades de se trazerem línguas indígenas para a forma escrita:

Registrei, em partituras, as cantigas recolhidas durante as minhas pesquisas e respectivos arranjos que são publicadas neste livro. No tocante à anotação das letras, porém, as dificuldades são imensas. Os índios são ágrafos. Não há como padronizar suas línguas e dialetos, que se modificam a cada geração. Cientistas, missionários, entidades como o Summer Institute of Linguistics (SIL), deram às línguas de cada tribo formas específicas de escrita. Escolhi, então, fazer uma anotação fonética elementar em alguns casos, que supre as necessidades do trabalho, permitindo uma compreensão fonográfica das palavras. (MIRANDA, 1997, p. 20)

Como relatamos acima, percebemos essa dificuldade ao compararmos as diferenças entre a letra escrita no livro e a pronúncia de Miranda no $C D$, e também não tivemos a oportunidade de ouvir a canção original, cantada por Uratana, para compararmos com a maneira pela qual Miranda "traduziu" essa canção ${ }^{128}$.

Aqui reproduziremos duas versões da letra: a escrita na partitura do arranjo original e a transliteração em italiano escrita na partitura realizada pela mestranda, e observações sobre as duas letras de acordo com o CD do grupo Beijo. Como não temos uma tradução, apresentaremos adiante uma exegese da letra.

${ }^{128}$ No texto Aspects of Paiter Suruí oral art (PUCCI, 2011), existe um link que nos remete à canção entoada por Momboar. filho de um pajé Paiter Suruí. Não tivemos acesso ao link, mas, gentilmente, Magda Pucci nos enviou por email o áudio da canção. Magda Pucci também nos informou que este canto, assim como o são os cantos de tradição oral em geral, nunca é cantado da mesma maneira, apresentando-se em incontáveis versões, com alterações tanto na letra, quanto na música. 


\title{
1. Mekô Merewá
}

\author{
engaba pamãi até oi kaled mã \\ bi kü era ongatchar \\ awabekaté ongatchar \\ bi aü
}

\section{Mekô Merewá}

engaba pamãgaré oi kaled mã

bi ku era ongaicia

auabekaté ongaicia

$\mathrm{bi} \mathrm{au}{ }^{129}$

A percepção atual da mestranda ao ouvir a canção realizada por Marluí e pelo grupo Beijo mostra a presença de um "g" ao final da palavra "pamãi" e a substituição da palavra "até" por "aré" (pamangaré). Ouve-se também "bi ke naiá" ao invés de "bi kü era", a presença da letra "i" no meio da palavra ongatchar (ongaitchar) e a ausência da pronúncia do "r" final.

A tradução literal da canção Mekô Merewá não foi encontrada no livro de referência, mas temos a exegese de seu texto no depoimento da antropóloga Betty Mindlin:

[...] A cantiga se refere à história do Veado, que Pálop, o herói cultural (Nosso Pai), manda à casa da Onça (Mekô) para buscar os ossos dos homens devorados por ela. Com os ossos, Pálop vai fazer uma nova humanidade, soprando-os com a fumaça do tabaco. A onça diz ao veado: Não brinca comigo não, não faz nada de errado que te como de verdade [...] (MINDLIN apud MIRANDA, 1997, pág. 156).

Em cantos indígenas, encontramos dificuldade na tradução das palavras ${ }^{130}$. Miranda (1997, p. 22) explica que "há casos em que os cantos são em línguas mortas

$\overline{129}$ Em italiano, "ci" corresponde ao som do que entendemos por "tchi". 
arcaicas que os índios entoam sem saberem seu significado, ou conhecendo-o parcialmente". Ela não cita Mekô Merewà dentre essas canções, mas como não foi realizada uma tradução literal da mesma, deduzimos que pertence a esses casos.

\section{Aspectos musicais}

Segundo as referências acima, a canção trata da difícil tarefa do veado mandado por Pálop (Nosso Pai) à casa da onça feroz (Mekô), para buscar os ossos das pessoas devoradas por ela, para que Pálop pudesse fazer uma nova humanidade com essas cinzas.

A canção dura em torno de um minuto e, dependendo da atividade a que foi vinculada, amplia-se sua duração ao ser repetida.

$O$ andamento indicado na partitura original (semínima pontuada igual a 120) não foi respeitado, e com cada grupo, dependendo do contexto em que a canção estava inserida, fizemos de maneira diferente. Por exemplo, as crianças do curso preparatório ao canto coral, posterior ao laboratório de verão, cantaram essa canção de duas maneiras: em forma de ciranda, começando bem devagar e acelerando a cada ritornello, assim como o movimento da roda, até chegar ao máximo de velocidade; e em várias formas, como descrito na atividade $A$ Onça e o Jabuti no capítulo III, item 3.4.3. Essa canção só foi apresentada em público de pais e amigos pelas crianças do laboratório de verão, quando foi cantada duas vezes seguidas, mantendo-se o andamento constante.

${ }^{130}$ Segundo Claudia Neiva Mattos "o traslado envolve barreiras de toda sorte, oferecendo diversos e numerosos problemas", entre eles: 1. a carência de um universo de referências intertextuais; 2. a enorme distância entre nossa cultura e a indígena, que compromete nossa capacidade de apreender a dimensão semântica ampla dos textos; 3. a desconfiança do indígena em relação ao "homem branco", que pode comprometer sua disposição em colaborar ou consentir na tradução; 4. a complexidade linguística, já que falamos de mais de 180 línguas distintas, com sua literatura constituída e conservada na tradição oral; 5 . o empobrecimento da performance vocal (a mobilização corporal, voz e ouvido, gesto e visão, fundamentos não descartáveis da poesia cantada e de seu efeito no receptor) ao passar para forma escrita, estática e muda; 6 . a dificuldade de traduzir símbolos complexos relativos ao significado e função desses cantos (MATTOS, 2006, p. 181-184). 
A canção transcrita por Miranda em compasso binário composto apresenta preponderância de semínimas e colcheias, preenchendo cada tempo com uma semínima seguida de colcheia na parte $\mathbf{A}$, com exceção do prolongamento da sílaba "ré" (c. 3 e 7) por uma semínima pontuada na repetição das frases a, que estão separadas por um silêncio de duas pausas de semínima pontuada. As frases da parte B (b e b') possuem a mesma figuração rítmica com predominância de colcheias separadas por uma pausa de colcheia. Essas frases têm também a mesma melodia com textos diferentes.

No final, temos uma coda de três compassos, em que o primeiro compasso contém duas semínimas pontuadas, sendo que a última é prolongada pela ligação a duas mínimas pontuadas e uma fermata na última nota.

Apesar de haver uma pausa de semínima pontuada escrita no início da partitura original e naquela realizada pela regente, na execução da peça essa foi suprimida tanto no começo como nas repetições, diminuindo a duração do silêncio, para que resultasse apenas numa pausa de respiração e tornando o primeiro compasso anacruse.

A tessitura geral da obra, de dó 3 a fá 3 , é pequena e muito adequada às crianças não habituadas a cantar, assim como o pequeno número de notas usadas: a canção é composta por apenas quatro frequências - fá 3, mi bemol 3, dó 3 e mi natural 3 - sendo que a última, o mi natural, aparece uma única vez e no final da peça, causando surpresa (ao menos para "ouvidos tonais"), o que, para a mestranda, traz um sabor de mistério.

Quanto à intensidade, a única indicação na partitura original se encontra na coda, um $\boldsymbol{p}$, que fortalece a sensação de mistério. Se esse foi o único momento com indicação de dinâmica precisa, podemos deduzir que o resto da peça tem outra intensidade. Mantivemos a intensidade geral entre $\boldsymbol{m p}$ e $\boldsymbol{m f}$, procurando uma interpretação próxima do volume da voz falada das crianças, adequada ao movimento da roda e dos passos que marcavam os tempos. Existe também um crescendo e diminuendo natural ligado à altura das notas, onde se observam o início e o clímax das frases nas notas fá 3 e mi bemol 3 (e, portanto, com intensidade mais forte) e o final das mesmas na nota dó (com dinâmica mais fraca). 
As duas pausas de semínimas pontuadas que separam a repetição da primeira frase, trazem o elemento de suspensão, como se deixassem um momento de reflexão para o ouvinte antes de repetir a frase. $O$ fato de a frase ser repetida duas vezes denota importância quanto ao seu significado: pode ser um aviso, um alerta, mas ficamos no universo da suposição por não termos a tradução literal das palavras. Se lembrarmos de que na canção o Veado é ameaçado pela Onça (Não brinca comigo não, não faz nada de errado que te como de verdade...), podemos supor - e apenas supor - que nessas primeiras frases a Onça está alertando o Veado para o perigo que corre.

Esses silêncios, se pensarmos que essa canção, originalmente, foi cantada em roda, com a pulsação marcada pelos pés, na verdade eram silêncios apenas vocais. Contudo, eles mantêm a característica de suspensão da melodia.

Quanto ao timbre, procuramos construir uma emissão vocal aberta e nasalada para maior proximidade à sonoridade original da canção. Enquanto emitir sons vocais abertos é fácil para um grupo de italianinhos, os sons nasalados são mais difíceis, devido às características fonéticas da língua italiana. Acreditamos que com grupos brasileiros a dificuldade seria inversa, ou seja, o trabalho estaria centrado em procurar vocais abertas, dado que os sons nasais estão presentes no português falado no Brasil.

A peça é constituída de duas partes ( $\mathbf{A}$ e $\mathbf{B}$ ) onde se dispõem três frases diferentes, e uma pequena coda, $\mathbf{A}=\mathbf{a}$ (c. 1 a 4), e sua repetição exata (c. 5 a 8 ); $\mathbf{B}=\mathbf{b}$ (c. 9 e10) e b' (c. 11 e 12); coda (c. 13 a 15). Em A, temos a repetição da mesma frase, tendo duas pausas de semínimas pontuadas separando. Entre as frases de B existe uma respiração (pausa de colcheia). Essas frases (b e b') têm a mesma estrutura rítmica e melódica, mas um texto diferente. Na coda, encontramos o elemento surpresa, a nota que destoa das outras, que aparece uma única vez e é mantida por dois compassos em $\boldsymbol{p}$.

Para entendermos os filtros usados nessa análise, é importante salientarmos que essa canção foi analisada pelo olhar da mestranda como regente coral ocidental, teuto-brasileira e que morou vários anos na Itália, baseada na percepção de Miranda, brasileira, mas não indígena, conhecedora da escrita musical tradicional, que conviveu com a população indígena dona desse canto. 
Deixamos, como sugestão para a pronúncia, a audição de Mekô Merewá interpretada pelo grupo Beijo e Marluí Miranda, em seu CD IHU - Todos os Sons.

\subsubsection{N'Kosi Sikeleli Africa}

\section{Motivações}

Conhecemos N'Kosi Sikeleli Africa em 1991, quando a pesquisadora cantou a partitura do arranjo escrito a mão por Lutero, antes da canção se tornar o hino oficial da África do Sul ${ }^{131}$. O que chamamos de "canção tema" da ACC, o maestro define como “... uma das mais emblemáticas do repertório do Cantosospeso, em todos os seus grupos, desde o de terceira idade até o infantil..." (FUCCI-AMATO; GALATI, 2013, p. 244). Essa canção, representativa da luta contra o apartheid, cantada e amada pelos povos africanos, era pouco conhecida na Europa naqueles anos. Era importante divulgar a música símbolo da luta contra o apartheid e o racismo numa Itália que, desde os anos oitenta, se deparava com a intensa imigração africana e os problemas inerentes à integração social entre pessoas de culturas diferentes.

Essa canção foi saboreada por todos os coros da ACC e de diversas maneiras: na versão completa a quatro vozes mistas, com solista, na versão reduzida dos quatro primeiros versos, a duas vozes ou apenas a melodia principal.

Em 1995 e 1996, realizamos turnês, concertos e uma gravação em estúdio ${ }^{132}$ com a cantora sul-africana Miriam Makeba ${ }^{133}$. Os concertos, promovidos pela produtora

131 Depois da posse, em 1994, do presidente Nelson Mandela, foram estabelecidos dois hinos nacionais. Desde 1997, o hino oficial da África do Sul é uma combinação de uma versão de N'Kosi sikelel' iAfrika e The Call of South Africa (Die Stem van Suid-Afrika) (SOUTH AFRICA, 2013).

132 Nos anos 90, o Coro Cantosospeso foi convidado pela Ponderosa Music para realizar um CD com diversos músicos convidados. Chegamos a realizar parte do projeto e gravamos músicas com Naná Vasconcelos, Dino Saluzzi, Zap Mamma e, com Miriam Makeba, registramos N'kosi sikeleli Africa, mas o projeto não foi adiante por falta de verba. 
Ponderosa Music, foram realizados em cidades importantes tais como Torino, Verona, Varese e Roma. Em Torino, onde fizemos um concerto no parque, contamos com uma plateia de dez mil pessoas; em Varese, tivemos a presença no público do escritor e jornalista Alessandro Baricco ${ }^{134}$, que escreveu uma crônica sobre o concerto (BARICCO, 2000, p. 47-49).

Os concertos abriam com a canção N'Kosi Sikeleli Africa, com Miriam Makeba e o Coro Cantosospeso, prosseguia com a Missa Luba, tendo como solista a cantora acompanhada pelo Coro Cantosospeso e um grupo de percussionistas, e finalizava com as músicas do repertório dos discos da cantora, realizados por ela e sua banda.

Tive o privilégio de me aproximar da Mama África, a então doce e enérgica senhora cantora e ativista social, para "ensiná-la" a cantar as partes solistas da Missa Luba. Dessa relação, entre tantas riquezas, histórias e trocas humanas, aprendi várias canções tradicionais sul-africanas, assim como a pronúncia da canção N'Kosi Sikeleli África $^{135}$.

Essa música foi cantada em diversos concertos e apresentações pelos grupos do Curumim, sozinhos ou em companhia dos coros da ACC, e era uma das preferidas da criançada: talvez porque a ouviram na voz da Makeba ou assistiram aos coros adultos da ACC; talvez pelo encanto daquela língua diferente ou pela melodia orecchiabile $^{136}$, ou mesmo pela facilidade em cantá-la; talvez porque a música está imantada pelas vozes daqueles que há um século a cantam como símbolo dos movimentos antirracistas. Talvez porque as crianças, livres como são, estejam em sintonia com a essência da canção.

133 Miriam Makeba (Joanesburgo, África do Sul, 1932 - Castel Volturno, Itália, 2008) é conhecida internacionalmente como "Mama Àfrica". A "imperatriz da canção africana" (também sua alcunha) saiu de seu país natal em 1959, quando ainda vigorava o regime do apartheid, e ficou no exílio por 31 anos, só retornando em 1990, a convite de Nelson Mandela. Ao lado de Harry Belafonte e, mais tarde, do ativista político e porta-voz dos Panteras Negras, Stokely Carmichael, dedicou sua vida, sua voz e seus cantos a causas sociais, à luta contra o racismo, até terminar seus dias após um show em homenagem ao escritor e jornalista italiano, Roberto Saviano, que sofria ameaças da máfia.

134 Alessandro Baricco (Torino, 1958), escritor italiano, autor, entre outros, do famoso livro Novecento, adaptado para o cinema por Giuseppe Tornatori com o título La leggenda del pianista sull'oceano, lançado no Brasil como $A$ lenda do pianista do mar.

135 Neste estudo, preferimos adotar a pronúncia do Coro Cantosospeso, que se difere em pequenos detalhes da de Miriam, como em malupakamissu, que Miriam dizia malupakanissu (ao invés de Mi, falava $\mathrm{Ni}$ ), e em tu de zoyetu, que Miriam pronunciava com um golpe de ar no $t \overline{\mathrm{e}}$ um $u$ parecido com o ü em alemão.

136 Orecchiabile é um adjetivo derivado de orecchio (ouvido), usado para expressar a qualidade de fácil memorização de uma melodia. 


\section{Fontes}

A partitura das crianças (ver ANEXO SS), realizada pela mestranda, são as partes de soprano e contralto extraídas da versão reduzida do arranjo a quatro vozes mistas do maestro Lutero, com montagem de ilustrações de Malangatana ${ }^{137}$, copiadas da capa do livro Vamos Cantar, Crianças (OLIVEIRA, 1981).

\section{Comentários}

Neste estudo, são analisadas as duas vozes superiores da partitura a quatro vozes (ver ANEXO TT), de onde foram extraídas as linhas melódicas da partitura infantil. A escolha de usar a partitura para coro misto nessa análise se deve aos seguintes fatores: a presença dos sinais de dinâmica e andamento (ausentes na versão infantil) e o elemento harmônico criado pelas quatro vozes mistas, vivenciado pelos curumins quando das apresentações conjuntas com os coros de adultos.

Essa partitura é um arranjo coral para quatro vozes mistas da canção, escrita em 1897 por Enoch Mankayi Sontonga (Cabo Leste, África do Sul, 1873 - 1905), regente coral, poeta, compositor, professor de escola metodista e personagem público sul-africano. A primeira estrofe, a parte analisada neste estudo, é de sua autoria e foi escrita originariamente em língua xhosa; outras estrofes em xhosa foram adicionadas mais tarde pelo poeta Samuel Mqhavi, e uma versão em sesotho foi publicada por Moses Mphalele em 1942 (SOUTH AFRICA, 2013).

Sontonga escreveu essa música para seu coro escolar, mas sua estreia se deu em 1899, na ordenação do Reverendo Mboweni, o primeiro sul-africano da etnia Tsonga a se tornar pastor metodista. O hino foi popularizado pelo Coro do Ohlange Institute e, em 1923, em Londres, foi gravada pela primeira vez numa versão para canto

137 Malangatana (Moçambique, 1936 - Portugal, 2011), artista plástico e poeta moçambicano, foi um dos fundadores do "Movimento Moçambicano para a Paz" e fez parte dos "Artistas do Mundo contra o Apartheid", além de ter produzido pinturas, esculturas, desenhos, cerâmicas, murais, poesias e músicas. 
e piano. Em 1925, tornou-se a música oficial do African National Congress (ANC) e, em 1960, a Zâmbia a adotou como hino nacional (SAHO, 2013).

Nossa análise parte do fazer musical de um coro infantil italiano, que se apropria da canção por meio do arranjo para coros adultos da ACC e da performance do mesmo, ou seja, estamos analisando uma versão que implica escolhas tanto no texto como na música. Pareceu-nos adequado manter essas escolhas porque, apesar de ser um hino autoral, a canção se popularizou e é cantada de diversas maneiras, com alterações tanto no texto como na música ${ }^{138}$. Esse fato se observa principalmente em canções de tradição oral e, portanto, lembramos que N'Kosi Sikeleli Africa está na "boca do povo" africano, na luta antirracista, assim como estava nos sons dos curumins e ainda está na voz dos coros da ACC. A canção, como a arte em geral e as tradições, está em movimento, não é estática em seus sentidos e em sua forma final, tanto transforma quanto é transformada.

\section{Texto em Xhosa e Zulu e a tradução em português}

N’Kosi Sikeleli Africa

N’Kosi sikeleli Africa

Malupakamissu upondo luaio

Izzuaimi tanda zoyetu

N'Kosi sikelela

tina lu sapoluaio ${ }^{139}$

\section{Deus (Senhor) abençoe a África}

Deus (Senhor) abençoe a África

Eleve sua glória

Ouça nossas preces

Deus (Senhor) abençoe

a nós, seus filhos ${ }^{140}$

138 Essas diversas formas de cantar a mesma música se encontram na internet. Sugiro as versões do show de 1987 com Miriam Makeba, Ladysmith Black Manbazo e Paul Simon; a parte do funeral de Steven Biko no filme Cry Freedom; o atual hino sul-africano e a versão do Coro Luther King. Como documento escrito, além dos apêndices desse estudo, sugiro a partitura do hino da África do Sul (SOUTH AFRICA, 1997).

139 Transcrevemos o texto conforme escrito na partitura infantil, uma transliteração em italiano, acordante com o arranjo e maneira de cantar dos coros adultos da ACC. O texto oferecido pelo governo da África do Sul é "Nkosi Sikelel' iAfrika / Maluphakanyisw' uphondo Iwayo / Yizwa imithandazo yethu / Nkosi sikelela, thina lusapho Iwayo" (SOUTH AFRICA, 2013). 


\section{Aspectos musicais}

As palavras do hino são uma prece, um pedido para que Deus (Senhor) abençoe a África e seus filhos. Como dissemos anteriormente, essa canção se tornou símbolo dos movimentos antirracistas no continente africano, representando o anseio pela liberdade e igualdade de direitos entre os povos.

Em seus dez compassos quaternários, em movimento andante, a melodia dispõe em cinco frases musicais os versos da estrofe, sendo que cada frase ocupa dois compassos. As primeiras três frases ( $\mathbf{a}, \mathbf{b}$ e $\mathbf{c}$ ) observam um mesmo modelo rítmico: em seus primeiros compassos, possuem quatro colcheias seguidas de duas semínimas; em seus segundos compassos, finalizam com a estrutura de duas semínimas (por vezes o primeiro tempo é preenchido por duas colcheias) seguidas de mínima. Na quarta (d) e quinta (e) frases, encontramos também a mesma estrutura rítmica entre elas: duas mínimas seguidas de duas colcheias, semínima e mínima, com pequena variação na quinta frase e notas de passagem no soprano. Observamos, assim, que as primeiras três frases possuem maior densidade rítmica que as últimas duas.

A tessitura geral da peça, para as crianças, situa-se entre o si 2 e o dó 4, onde o soprano - que tem a melodia principal - vai de fá\# 3 a dó 4 , e o contralto, de si 2 a lá 3, compreendendo uma tessitura confortável para coro infantil. As melodias prosseguem por graus conjuntos, apresentando saltos esporádicos de pequena extensão, na maior parte das vezes saltos de terças, e apenas um salto descendente de $4^{\mathrm{a}} \mathrm{J}$ (entre c. 5 e 6 , no contralto).

As intensidades estão entre $\boldsymbol{m f}$ e $\boldsymbol{f}$, distribuídas entre os crescendo e decrescendo naturais das primeiras duas frases; prossegue com o crescendo da terceira frase que culmina no início forte da quarta frase. A frase $\mathbf{d}$ (c. 7 e 8 ) possui a maior riqueza dinâmica da peça: seu primeiro compasso (c. 7) inicia em $\boldsymbol{f}$, decresce e prepara o compasso seguinte, que tem um crescendo e decrescendo interno. Na última frase mantemos o $\boldsymbol{m f}$.

140 Tradução nossa do inglês: "God Bless Africa / Raise high Her glory / Hear our Prayers / God bless us, we, her children" (SOUTH AFRICA, 2013). 
A canção na tonalidade de Sol Maior inicia com um acorde de mi menor, sua Tr. Na peça, encontramos o uso predominante de $\mathbf{T}$ e $\mathbf{D}$, intercaladas por $\mathbf{T r}$ e $\mathbf{S r}$, e uma única presença de $\mathbf{S}$ (c. 7):

$$
\begin{aligned}
& \text { frase } \mathbf{a}=\operatorname{Tr}-\mathrm{D} 7-\mathrm{T}-\mathrm{Tr}-\mathrm{D} 7-\mathrm{T} \\
& \text { frase } \mathbf{b}=\mathrm{T}-\mathrm{Sr}-\mathrm{T}-\mathrm{D} 7 \\
& \text { frase } \mathbf{c}=\mathrm{Tr}-\mathrm{D} 7-\mathrm{T}-\mathrm{D} 7-\mathrm{Tr} \\
& \text { frase } \mathbf{d}=\mathrm{S} 6-\mathrm{T}-\mathrm{D}-\mathrm{T} \\
& \text { frase } \mathbf{e}=\mathrm{Sr}-\mathrm{T}-\mathrm{D}-\mathrm{T}
\end{aligned}
$$

\begin{tabular}{|c|c|c|}
\hline $\begin{array}{l}\text { Elementos } \\
\text { rítmicos }\end{array}$ & $\begin{array}{l}\text { Parte } \mathbf{A} \text { (frases } \mathbf{a}, \mathbf{b} \text { e } \mathbf{c} \text { ) } \\
\text { predominância de figuras }\end{array}$ & $\begin{array}{l}\text { Parte } \mathbf{B} \text { (frases } \mathbf{d} \text { e e } \text { ) } \\
\text { maior incidência de mínimas }\end{array}$ \\
\hline melódicos & $\begin{array}{l}\text { de curta duração } \\
\text { regiões mais agudas }\end{array}$ & regiões mais graves \\
\hline $\begin{array}{l}\text { harmônicos } \\
\text { primeira }\end{array}$ & $\begin{array}{l}\text { predominância da } T r, T \text { e } D \\
\text { (esta parte inicia e termina } \\
\text { com a } T r \text { ) }\end{array}$ & $\begin{array}{l}\text { predominância da } T \text { e } \quad \text {; } \\
\text { vez que aparece a } S\end{array}$ \\
\hline dinâmicos & $\boldsymbol{m f}$ para o $f$ & $f$ para o $m f$ \\
\hline
\end{tabular}

De acordo com os elementos analisados, adotamos a divisão da peça em duas partes, em que a primeira consta de três frases, e a segunda, duas frases:

O clímax da canção está claramente definido no c. 7: esse é o compasso de dinâmica mais forte; é onde aparece pela primeira - e única - vez a função de $\mathbf{S}$. Inicia com intervalo de segunda maior entre as vozes superiores; a palavra Deus (Senhor) é repetida; e só então se inicia o segundo período da peça.

O timbre usado nessa canção é aberto e mantém as seguintes características das línguas: o $n$ inicial, antes do $k$ ( $\left.n^{\prime} k o s i\right)$, suaviza tanto o $k^{141}$ como a entrada da primeira nota; o $t$ do c. 9 (tina) é pronunciado como na palavra tinha na pronúncia do português paulistano.

141 O $n$ não é pronunciado, mas produzido no palato antes do $k$ : ao invés de termos a explosão gutural do som do $K$ (ou $c$ duro, em português), essa consoante é suavizada levando a ponta da língua ao palato, na intenção de produzir o som do $n$ antes do $k$, o qual é produzido no palato. 
Sugerimos a audição do N'Kosi Sikeleli Africa pelo Coro Cantosospeso, regido por Lutero e com a solista, Danae Rikos, uma de nossas curuminhas, na faixa 1 do CD Cantosospeso canta Bach e Afrika. (LUTERO, CANTOSOSPESO, 2005).

\subsubsection{Tzun Tiãn Lai}

\section{Motivações}

Em 1999, foi desenvolvido um projeto de inserção social de crianças chamadas extra-comunitari, termo italiano para definir os nascidos em países fora da então Comunidade Comum Europeia (hoje União Europeia), o que resultou no espetáculo Girotondo e Filastrocche (Ciranda e Parlendas), relatado no capítulo I, página 54.

Como dissemos no capítulo I, Tzun Tiãn Lai foi uma das canções recolhidas nesse projeto. No espetáculo, foi apresentada apenas sua linha melódica e, mais tarde, foi elaborado um arranjo, que permite a realização da canção em uma, duas ou três vozes, dependendo das características do grupo infantil que a canta.

Em junho de 2003, fizemos um encontro entre dois coros Curumim - Coro Curumim da Libereria Claudiana e coro Curumim de preparação ao canto coral da Scuola di Via Guicciardi - reunidos com alguns integrantes do Coro Cantosospeso, em uma apresentação de quarenta minutos no teatro da Escola, onde as crianças cantaram esse arranjo, sendo que o grupo iniciante cantou o tema, e o coro avançado, o arranjo integral. 


\section{Fontes}

A canção Tzun Tiãn Lai foi oferecida à mestranda por uma criança, que se apresentou como chinesa. A menininha era dotada de uma bela voz, afinada, e cantava a música acompanhando com gestos. Trabalhamos essa canção com poucas informações sobre a tradução, pois a criança mal falava o italiano. O que conseguimos intuir na época, pela da interpretação de seus gestos, é que a música tratava de flores e borboletas.

Nesse estudo tivemos a oportunidade de rever a canção e elaborar um novo arranjo para ser utilizado por coros infantis brasileiros. A seguir, relataremos nosso percurso no sentido de encontrar a origem e o significado da letra.

Por anos, esta mestranda cantou Tzun Tiãn Lai para vários chineses, que entendiam vagamente seu significado e diziam não conhecê-la. Em fevereiro de 2013, encontramos sua tradução por meio de nossa informante Kaling, budista e comerciante do Templo Zulai de Cotia (SP), de monges budistas vindos de Taiwan ${ }^{142}$, que compreendeu a canção, traduziu e a escreveu em mandarim (ver ANEXO UU). Kaling também informou que as palavras da canção fazem parte da cultura da infância de seu país. Por sugestão do orientador deste estudo, procuramos uma pessoa para fazer a romanização do mandarim, o que foi realizado por Chen Lijin, estudante do quarto ano de letras da FFLCH - USP (ver ANEXO VV). Usando os caracteres romanos, de acordo com o sistema Pinyin ${ }^{143}$, encontramos a parlenda chinesa Chun Tian Dao, muito parecida com a nossa canção, que fala da primavera que está chegando, de flores, de abelhas, mas difere quanto ao uso de algumas palavras, extensão do texto e métrica poética $^{144}$.

${ }^{142}$ Taiwan, Ilha de Formosa, Formosa ou República da China, é um país formado por uma maioria de chineses e seu idioma oficial é o mandarim.

143 Pinyin (ou formalmente hanyu pinyin) é o sistema de romanização do mandarim mais usado e significa "fonética" ou, literalmente, "som letrado". Foi aprovado pelo governo da República Popular da China em 1958 e, a partir de 1982, foi adotado pela Organização Internacional de Padronização.(LIMA, 2012, p. 32-33) É também o sistema adotado no curso de Letras da USP. (LIMA, 2012, p. 16)

144 "Chūn tiān dào, chūn tiān dão/Huā ér duo duo kāi kou xiào/Cao ér lo, niao ér jiào/Hú dié mì fēng qí wai dão", que significa: A primavera está chegando, a primavera está chegando/As flores começam a 
Quanto à melodia, não encontramos referências, e nenhum de nossos informantes - da República da China (Taiwan) ou da República Popular da China - a reconheceu. De acordo com o resultado da nossa pesquisa, pudemos então afirmar, com certeza, o idioma, o significado e realizar a tradução para o português.

\section{Comentários}

O arranjo usado no Coro Curumim ${ }^{145}$ (ver ANEXO XX) foi criado pela pesquisadora para atender às necessidades do grupo avançado do PIC de 2002/2003. A primeira necessidade era a de fazer o grupo cantar explorando o melhor de suas tessituras, pois havia crianças com vozes agudas e que tinham prazer em cantar naquela tessitura, enquanto outras que ainda precisavam desenvolver os agudos, mas podiam cantar na região média, e outras ainda que se sentiam bem e que possuíam emissão vocal na região grave.

Analisaremos aqui um arranjo criado para este estudo (ver ANEXO WW), resultado do novo olhar sobre o material recolhido. Nele, modificamos a escrita do texto de acordo com as novas informações, procurando adequá-lo ao público brasileiro, acrescentamos um ritornello no final da peça, modificamos a frequência das notas, alteramos a fórmula de compasso quaternário em binário e colocamos um ritardando nos dois últimos compassos ${ }^{146}$.

sorrir (desabrochar)/A grama fica verde, pássaros começam a cantar/Borboletas e abelhas dançam juntas (LISA, 2013, tradução nossa).

145 Inicialmente, denominamos o arranjo de Zun Tin Lai como "Canção Tradicional da China", porque acreditávamos que a criança fosse chinesa (conforme nos foi apresentada). Na partitura do novo arranjo feito para este estudo, a classificaremos de "canção em mandarim", por termos certeza da língua usada, mas não do País de origem. Devido às novas informações sobre a língua, e procurando adaptá-la ao nosso idioma, modificamos o nome da canção para Tzun Tiãn Lai.

146 Com exceção do ritornello, alterado por um sentido estético da arranjadora, as outras alterações musicais citadas foram feitas para que a canção se aproximasse da original. 


\section{O texto em mandarim e a tradução em português}

\section{TZUN TIÃN LAI}

Tzun tiãn lai, tzun tiãn lai

Hua er tuor tuor cai

Hun hua cai

Pai hua cai

Mi fan hu tie tuô fei lai

\section{CHEGOU A PRIMAVERA}

Chegou a primavera, chegou a primavera

Todas as flores se abriram

Flor vermelha

Flor branca

Abelha e borboleta estão chegando

Devido à complexidade do tema e, principalmente, pela provável origem popular da canção, este estudo não se aprofundará na sua tradição poética de origem, que carrega mais de 2.500 anos e que fascinou grandes poetas ocidentais como Ezra Pound $^{147}$ e os concretistas brasileiros. Contudo notamos que, apesar de desconhecermos sua autoria e de ser um singelo poema infantil, a canção carrega dois traços recorrentes na poética chinesa, como a natureza descrita em pinceladas e a essência de um pensamento plástico: "A poesia chinesa se fundamenta em imagens, as quais rendem supérfluas conexões lógicas, o que, para os ocidentais, é fundamental" (SPADARO, 2008, p. 5, tradução nossa).

Essas conexões "lógicas" estão ausentes na tradução feita por nossa segunda informante, Kaling (ver ANEXO WW). A pesquisadora - longe de ser poeta! - decidiu por uma tradução que fizesse sentido para as crianças, alterando as métricas do texto em mandarim (3-3-5 / 3-3-7) e procurando enquadrar em português simples as melodiosas palavras, pintadas originalmente em ideogramas.

147 Ezra Pound (1885 - 1972), poeta e crítico norte-americano. Em 1915 publicou suas traduções de poemas chineses no livro Cathay.

"Pound foi o fundador da teoria do ideograma aplicado à poesia ocidental a partir da publicação, em 1919, dos escritos de Ernest Fenollosa a respeito da utilização poética dos caracteres chineses, ou ideogramas. A importância do ideograma, enquanto instrumento para a composição poética concretista, deriva de sua consonância com propostas do movimento, tais como a ênfase na visualidade significativa, a busca pela comunicação de estruturas-conteúdos e o apreço pelas relações entre as formas." (SANTOS, 2011, p. 2). 


\section{Aspectos musicais}

Tzun Tiãn Lai foi arranjada pela mestranda para coro infantil a três vozes. A peça dura em torno de um minuto, com o andamento de semínima próximo de $90^{148}$.

O ritmo dos compassos binários é simples e repetitivo, e o motivo rítmico preponderante aparece para dar movimento às duas semínimas de igual altura (notas repetidas), seguidas pela mínima.

As figuras de quatro semínimas, duas mínimas e uma semibreve, que preenchem os compassos, aparecem quando existe movimento melódico, ou seja, quando as alturas são diferentes.

A obra é dividida em três partes, relacionadas com a entrada de cada voz: A c. 1 a 9; B - c. 10 a 18 ; C - c. 19 a 29, onde temos um ritornello. A melodia original é dividida em duas partes, sendo a primeira (frase a) composta por quatro compassos e a segunda (frase $\mathbf{b}$ ), por cinco. A mesma divisão de frases é mantida em todas as partes (A, B e C).

$\mathrm{Na}$ seção A' temos a apresentação da melodia principal (V. 3); em B é introduzida a V. 2 que imita o tema uma quarta acima, nota contra nota. Com a entrada da V. 3 em C, apresentando melodia diferente das anteriores, temos a formação de acordes que não caracterizam tonalidade ou modo.

A tessitura geral do arranjo é de sib 3 a ré 4 : V. 1 - sib 3 a fá 3, V. 2 - mi 3 a sib 3, V. 3 - sol 3 a ré 4.

As duas primeiras melodias são construídas em quartas paralelas, alternando graus conjuntos com saltos esporádicos, que não excedem uma 5 âJ. A última melodia é construída preponderantemente com a sequência salto de $3^{\mathrm{a}}$ ( $\mathrm{M}$ e $\mathrm{m}$ ) descendente e graus conjuntos ascendentes e descendentes. Cada frase funciona com um impulso melódico em grau conjunto que desencadeia uma melodia de saltos, para depois repousar.

${ }^{148} \mathrm{O}$ arranjo realizado com o Coro Curumim possuía um andamento bem lento e era pensado em compasso quaternário. Esse novo arranjo procura se aproximar mais da canção original, adotando um andamento também mais próximo, assim como se aproxima, na voz tema, da região cantada pela menina da Scuola di Gratosoglio, que inicia a melodia com um dó sustenido 3. 
A peça é construída com a sobreposição de duas melodias principais em escala pentatônica maior, que usa apenas as quatro primeiras notas da escala (V. 1 e V. 2). A primeira apresentação da melodia se conclui na nota sib 3 (c. 9); na segunda apresentação, onde a melodia principal é apresentada uma quarta acima, a conclusão é em mi 3 (c. 18). A canção termina em uníssono com a nota sol 3, que resulta no tema da V. 3, na apresentação de todas as notas da escala pentatônica maior: si b, do, ré, fá e sol.

Durante os 18 primeiros compassos, tanto a primeira como a segunda voz possuem a mesma importância. A partir do c. 19, a voz central (V. 2) ganha mais importância, pois possui as notas fundamentais dos acordes construídos.

A presença dos acordes, construídos a partir do c. 19 devido à sobreposição das três melodias, é esporádica e nenhum se encontra na sua posição fundamental, sendo irrelevante a análise dos mesmos, com exceção apenas do acorde de mi bemol maior com a quinta no baixo, no c. 27, que causa certa "estranheza" na peça. Esse é o único momento em que temos um acorde no final da frase.

A dinâmica para todas as vozes está entre o $\boldsymbol{m p}$ e $\boldsymbol{m f}$, próximo à voz falada, com crescendo e decrescendo inerentes à declamação do texto, existindo um aumento de intensidade relacionado à entrada de cada uma das vozes.

O timbre usado na interpretação da canção é muito aberto, favorecido pela constante presença da vogal $i$.

O fio condutor da peça é a melodia recolhida. O tema está sempre presente em sua forma original nas V. 3 e 2, com exceção do último compasso, onde todas as vozes terminam em uníssono na nota sol 3, por sinal a única nota da escala pentatônica que não estava presente na melodia original da V. 3.

Essa canção, além de trazer o sabor de uma cultura distante, é um bom motivo para fazer exercícios com escalas pentatônicas e sobreposição de $4^{\underline{a}} \mathrm{~s}$ paralelas. As crianças gostavam de cantá-la porque é uma melodia fácil, de rápido aprendizado e fácil afinação.

Para melhor compreensão da pronúncia, sugerimos a audição da canção de nossa pequena informante de olhos amendoados. (YOUTUBE, 2013) 


\section{VAMOS BRINCAR?}

O título acima, inspirado na primeira frase da canção moçambicana Os Brinquedos do Cancioneiro vol. I - Vamos cantar crianças (OLIVEIRA, 1981, p. 20-21), é a tônica deste capítulo que trata dos aspectos lúdicos no Coro Curumim e da sistematização de atividades lúdicas dirigidas à interpretação de um repertório multicultural.

A palavra brincar $^{149}$ é entendida aqui (assim como suas derivações brinquedo e brincadeira) em seus significados diretamente relacionados ao jogo. Nossa escolha se deve à necessidade de circunscrever um tema abrangente e vastamente estudado, para focar na busca dos aspectos lúdicos usados no Coro Curumim, por meio de referências encontradas nos livros $O$ Jogo teatral no livro do Diretor, de Viola Spolin, e Homo Ludens, de Johan Huizinga.

Aqui não serão tratadas as diversas definições do jogo ou seu estudo em diferentes áreas do conhecimento, a fim de direcionar o foco para alguns conceitos dos dois autores referidos.

Por meio das reflexões sobre esses dois livros, trouxemos à tona os aspectos do jogo que estavam na base dos trabalhos realizados no Coro Curumim, e nos servimos do caráter de manual do livro de Spolin como inspiração para a sistematização de atividades lúdicas.

Neste capítulo, falaremos da trajetória pessoal da mestranda, em vestes de educadora, na aquisição de saberes; dos aspectos lúdicos presentes no Coro Curumim, iluminados pelos conceitos de Huizinga e Spolin; da construção de um esquema de ensaio, visando à organização das atividades lúdicas e à sistematização e descrição dessas atividades.

\footnotetext{
149 Brincar significa "1. distrair-se com jogos infantis, representando papeis fictícios. 2. entreter-se com (um objeto qualquer ou uma atividade qualquer). 3. mexer distraidamente em algo. 4. não falar a sério, gracejar." (HOUAISS, p. 327).
} 


\subsection{A Maestrina Brincando de Educadora}

Os grupos do Coro Curumim foram construídos com foco na preparação das crianças para a performance de um repertório multicultural e não estritamente na educação. Porém, no trabalho de coro infantil amador, é tão imprescindível quanto natural a aproximação com a pedagogia: a mestranda, consciente ou não, vestiu as roupas de educadora para dar conta da transmissão de saberes atinentes à prática coral, comportando-se como uma maestrina, no sentido italiano do termo ${ }^{150}$. Esses saberes vão desde a contextualização das músicas e o aprendizado de suas melodias até as técnicas vocais; da condução de uma aula/ensaio, que cativa e seduz, até a transmissão e a conscientização de noções musicais, tais como parâmetros sonoros e leitura da escrita musical.

Por muitos anos, relutamos com a ideia de assumir essas características pedagógicas no trabalho do Coro Curumim, talvez por não nos sentirmos merecedores do título de educadores; ou porque essas práticas de ensino foram realizadas de maneira intuitiva, de acordo com a formação musical da mestranda, observando o trabalho de outros regentes, colhendo informações esparsas em livros, ouvindo e praticando músicas, colocando "a mão na massa" e indo em busca de recursos para dar suporte e enfrentar as dificuldades inerentes ao ensino da música.

No início das atividades com o coro Curumim, tínhamos muitas dificuldades, tais como inseguranças musicais e vocais, e falta de tato com as crianças, mas acreditamos ter conseguido superá-las, pelo gosto de fazer um trabalho de coro infantil, de fazer música com crianças. Por causa da responsabilidade que sentíamos em transmitir as linhas melódicas das canções aos curumins, a mestranda teve aulas de canto lírico, e aprimorou as técnicas vocais e de regência coral. Nesse sentido, fizemos arranjos corais, procuramos, recriamos e inventamos histórias e jogos.

A maestrina não sabia, até então, que o lúdico, empregado na educação, era história antiga, que remonta à civilização greco-romana; nem que, na Idade Média, o

\footnotetext{
${ }^{150}$ Maestrina, em italiano, designa professoras de crianças no ensino formal. Maestrina ou regente, no sentido com que encontramos em português, é denominada direttrice.
} 
lúdico estava presente nas práticas educativas formais e informais, tanto para monges, reis, educadores, educadoras e eruditos, como para cidadãos comuns (LAUAND, p. 1).

A educadora não sabia, naquela época, que Rousseau acreditava que a melhor maneira de instruir as crianças era através de jogos (MORAIS, 2004, p.35) e que foi ele o "primeiro pensador da educação a apresentar um esquema pedagógico especialmente voltado à educação musical" (FONTERRADA, 2008, p. 60).

A regente desconhecia a fundo as ideias de Pestallozi e sua abordagem centrada na criança, e mais ainda que esse educador "deu ênfase à utilização de canções no processo educativo" (FONTERRADA, 2008, p. 61) e ensinava os sons antes da grafia musical ou de pronunciar seus próprios nomes.

A cantora não conhecia em detalhes o trabalho dos jardins de infância de Froebel, mas já tinha ouvido falar da adequação dos espaços infantis e dos jogos instrutivos de Montessori, assim como usufruiu de seu pensamento ao trabalhar em espaços apropriados para crianças, com cadeiras e mesas na medida dos pequenos, em ambientes pensados para abrigar grupos infantis.

A pesquisadora pouco conhecia os educadores musicais, apesar de usar exercícios que pertencem à rythmique de Dalcroze e também a prática do canto coral sem o uso do piano como referência das linhas melódicas, como fez Kodaly. Ainda não havia compreendido, na ocasião, os três aspectos que Willems considerava para desenvolver seus estudos sobre a audição: o sensorial, o afetivo e o mental, entendidos como processos interligados e simultâneos (WILLEMS, 1972), nem sabia da importância que esse educador dava à transmissão de cantos às crianças; hoje, essa importância nos parece lógica, uma vez que Willems relaciona a melodia à afetividade $e$ considera a "afetividade o elemento central da escuta" (FONTERRADA, 2008, p. 147).

Aquela jovem direttrice bem intencionada, sequer podia imaginar que as atividades lúdicas que usava foram estudadas e classificadas como jogos simbólicos (nas histórias e nas representações das mesmas) e jogos de regras por Jean Piaget, e que a idade aproximada para a aplicação desses jogos coincidia com as dos pequenos curumins (PIAGET, 1978, p. 175 e 180).

Nem todos os educadores acima citados são referidos diretamente neste estudo, mas temos a consciência de que o contato com essas leituras construiu os 
conhecimentos de base para as reflexões realizadas neste capítulo. Em companhia de novos saberes, temos agora outro olhar em relação àquelas atividades lúdicas realizadas com finalidades pedagógicas, elaboradas entre 1993 e 2003.

A seguir conversaremos com dois autores que nos ajudaram a perceber, definir e significar o lúdico em nossas atividades.

\subsection{Dançando com Huizinga e Spolin: aspectos Lúdicos em Homo Ludens, em 0 jogo teatral no livro do Diretor e no Coro Curumim.}

Huizinga usa o termo lúdico como sinônimo de jogo e delimita seu estudo em suas manifestações sociais. Para esse autor, a natureza e o significado do jogo são compreendidos em seu âmbito cultural, estando essa compreensão calcada na observação das ações do jogo em sua "significação primária", baseada na manipulação de imagens e na imaginação da realidade, para captar seus significados e valores (HUIZINGA, 2004, p. 7).

Spolin se utiliza do jogo no teatro, como técnica de ensaio, desenvolvendo e sistematizando jogos com finalidades precisas e condizentes com as necessidades de cada momento do percurso da construção da cena teatral.

Considerando o coro infantil como um organismo sociocultural quanto às suas inter-relações humanas e produção artística, podemos dialogar com Huizinga no sentido de buscar semelhanças e diferenças entre os aspectos lúdicos encontrados em Homo Ludens e na práxis do Coro Curumim.

Em Spolin, encontramos os significados de nossa prática de jogos e atividades lúdico-musicais. A intenção primeira dessa educadora na elaboração dessas atividades era a de resolver "problemas" teatrais por meio de jogos, do ato de jogar (SPOLIN, 2001, p. 15). Os jogos que propunha, quase sem exceção, foram desenvolvidos com o único propósito de fazer com que alguma coisa acontecesse no palco (SPOLIN, 2001, p. 18). Apesar das particularidades das áreas - teatro e canto coral infantil encontramos ressonância com as ideias da autora em diversos aspectos, tais como o 
desenvolvimento dos saberes individuais, levando em consideração características próprias de cada grupo, objetivando a realização da "peça"151 escolhida.

Huizinga se diz, em relação à competição e ao jogo, "firmemente convencido da existência de uma identidade profunda entre ambos" (HUIZINGA, 2004, p. 36), encontrando, na competição, características lúdicas próprias do jogo. Essas duas noções são aproximadas, usando como referência os ludi, palavra em latim que definia os combates dos gladiadores romanos:

Assim, para voltar a nosso ponto de partida, os ludi romanos, podemos afirmar que a língua latina tinha toda a razão ao designar as competições sagradas pela simples palavra jogo, pois essa palavra exprime, da maneira mais simples possível, a natureza única dessa força civilizadora. (HUIZINGA, 2004, p. 85)

Apesar de a competição estar presente como motivação lúdica em alguns dos jogos que propusemos no Coro Curumim, e admitirmos a identidade entre ambos - jogo e competição - nas situações descritas pelo autor, a própria natureza das nossas atividades os afastava: o coro era um espaço recortado de uma sociedade competitiva, uma realidade outra, onde os participantes jogavam para se divertir e aprender, onde o jogo se realizava pela sintonia e a cooperação entre eles, ou seja, onde todos saíam ganhando.

Spolin se refere à competitividade como elemento pessoal, desagregado do todo: "Como indivíduos, somos isolados uns dos outros, cheios de limitações, medos, tensões, competitividade, preconceitos e atitudes preconcebidas." (SPOLIN, 2001, p. 17).

Esses autores nos deram a chave para compreendermos o lugar da competição nos jogos, circunscrita ao "eu" superdotado, que desponta e prevalece na comunidade. Nos exemplos de Huizinga, encontramos jogos em que existem vencedores e perdedores, que podem ser equipes (grupos) ou indivíduos; na citação acima, Spolin afirma esse mesmo conceito com outras palavras, considerando como qualidade da pessoa isolada. Neste estudo, falamos de canto coral infantil, do cantar em conjunto, no qual o indivíduo é fundamental, desde que suas expressões colaborem com a

151 Usamos aqui a palavra peça tanto em referência ao espetáculo teatral como sinônimo de obra musical. 
realização do objetivo comum, e entendemos que a competitividade exacerbada, que se descola de um contexto lúdico coletivo, atrapalha tanto a cena teatral quanto a realização do canto coral.

Spolin sequer menciona outra vez a palavra competitividade, concentrando suas ideias nos jogos cooperativos, que integram as expressões individuais ao grupo. Nesse sentido, a autora delineia outro aspecto presente em nossas atividades, a integração de vários níveis de experiência dos participantes: "Atuar/jogar [cantar] junto traz todos os jogadores para o mesmo espaço, não importando a diversidade de sua formação e treinamento." (SPOLIN, 2001, p. 16). Como já relatamos no capítulo I (p.31), em nossos grupos se encontravam crianças de diversas idades - e, portanto, competências adequadas às mesmas - assim como com níveis diferentes de habilidades musicais, sendo a integração dessa diversidade essencial para 0 funcionamento do Curumim, para o cantar em conjunto.

Os momentos dos jogos, elaborados de maneira que todos pudessem contribuir com suas características individuais em favor do cumprimento de determinadas regras, assegurava a harmonização do grupo e o estabelecimento das bases para o canto coral. No jogo de equipe, aprende-se a conviver, a cooperar; não é necessário dizer para a criança mais velha ajudar a mais nova, isso faz parte do jogo quando está claro que o objetivo é realizar uma atividade em conjunto, na qual todos são necessários para uma meta comum.

Huizinga define o que entende por lúdico, circunscrevendo seus aspectos e sua natureza:

$\mathrm{Na}$ tentativa de resumir as características formais do jogo, poderíamos considerá-lo uma atividade livre, conscientemente tomada como "não séria" e exterior à vida habitual, mas, ao mesmo tempo, capaz de absorver o jogador de maneira intensa e total. É uma atividade desligada de todo e qualquer interesse material, com a qual não se pode obter qualquer lucro, praticada dentro de limites espaciais e temporais próprios, segundo uma certa ordem e certas regras.(HUIZINGA, 2004, p.17)

Essas características do jogo se encontram não apenas em nossas atividades lúdicas, mas na atividade coral amadora como um todo: raramente alguém canta por obrigação, mas por prazer; as atividades corais (ensaios, apresentações, gravações) 
são momentos outros da vida cotidiana; para cantar é necessária a presença, a absorção do cantor de maneira intensa e total (aspectos também enfatizados por Spolin); em coros amadores, a expectativa de uma compensação econômica inexiste; as atividades corais acontecem em limites espaciais e temporais definidos, e, para que se realizem, é necessário o estabelecimento de uma ordem e o cumprimento de determinadas regras.

Visto dessa maneira, atividades lúdicas dentro de um contexto lúdico por si só parecem redundantes, sendo maior essa redundância no coro infantil, tendo em vista que a infância é a fase em que o lúdico é soberano. A própria atividade musical pode ser entendida como jogo, sendo usada, em algumas línguas, a mesma palavra para designar o fazer musical e o jogo, tais como play em inglês e spielen em alemão, conforme resume Salles:

Se, em algumas línguas, "brincar", "jogar" e "tocar (música)" são designados por um mesmo termo (no francês "jouer", no alemão "spielen" e no inglês "play"), a ideia de se definir a prática musical como brinquedo ou jogo revela-se bastante antiga e mesmo óbvia. Seria interessante, inclusive, determinar quando e como esses termos passaram a ser emprestados à música. (1996, p. 43)

De fato, a música parece ter, além de seu aspecto técnico e estético, uma dimensão lúdica, que alimenta o prazer em seu fazer. Segundo Huizinga (2004, p.183), "tudo o que se relaciona com a música está situado no interior da esfera lúdica". Essa base lúdica também existe no teatro, jogo simbólico por excelência (na acepção de Piaget), e aqui se explica nossa proximidade com o livro de Spolin. Se em Huizinga pudemos elucidar conceitos sobre o lúdico em nossas atividades, com Spolin encontramos significados para a nossa prática.

Podemos afirmar que o canto coral infantil amador é lúdico por natureza, mas as estratégias lúdicas de ensino, instrução e repasse dos conteúdos e habilidades musicais são escolhas de conduta pedagógica e, portanto, podem ou não estar presentes em coros infantis amadores, e também possuem diferentes medidas: assim como em Spolin (2001, p. 33), nossos jogos não substituíam os ensaios.

Em nosso caso específico, jogávamos em todos os ensaios, mas havia momentos em que informações precisas eram passadas por meio da palavra ou do 
fazer musical, sem um jogo elaborado para tanto, sem com isso perder os aspectos lúdicos que estavam na base do nosso fazer coral, como o prazer, a fruição musical e o divertimento.

Huizinga define a função do jogo a partir de dois aspectos, "uma luta por alguma coisa ou a representação de alguma coisa", de forma que "essas duas funções podem também por vezes se confundir, de tal modo que 0 jogo passe a representar uma luta, ou então se torne uma luta para melhor representação de alguma coisa." (HUIZINGA, 2004, p. 17).

Entendemos a primeira função - a luta por alguma coisa - como ação originária da vontade de atingir os objetivos propostos. Assim, essas duas funções, em nossas estratégias lúdicas, estão subordinadas às funções pedagógicas, que se definem de acordo com os objetivos das atividades lúdicas e suas finalidades específicas: transmitir e ensinar conteúdos e habilidades dirigidos à interpretação de um repertório multicultural.

Aqui nos diferimos de Spolin quanto às intenções dos jogos: para a educadora teatral, o jogo vai além da simples transmissão de conhecimentos e habilidades, colhendo, ao jogar, oportunidades de desenvolvimento do potencial humano e investindo esse crescimento e a aquisição de saberes outros na construção da cena. A preocupação da maestrina era a de fazer um coro infantil apto a interpretar um repertório multicultural, usando atividades lúdicas, ainda sem subsídios predefinidos para uma reflexão sobre os "efeitos colaterais" desses jogos e da maneira como foi imposta a prática coral, com raros momentos de avaliação durante o processo. Contudo, encontramos, na prática passional e intuitiva do Coro Curumim, atributos descritos por Spolin.

Nossas atividades lúdicas não partiam da vontade espontânea das crianças e, sim, da determinação da maestrina ou da equipe de trabalho, salvo as situações em que as crianças pediam a repetição das atividades e havia a possibilidade de atendêlas. Apesar dessa maneira de propor atividades lúdicas parecer autoritária, uma das 
características fundamentais do jogo - a liberdade entendida como ação voluntária anulava qualquer imposição ${ }^{152}$ :

Na relação autoritária, a regra é percebida como lei. Na instituição lúdica, a regra do jogo pressupõe o processo de interação. O sentido de cooperação leva ao declínio o misticismo da regra quando ela não aparece como lei exterior, mas como o resultado de uma decisão livre, porque mutuamente consentida. Cooperação e respeito mútuo são formas de equilíbrio ideais que só se realizam através do conflito e exercício da democracia. (SPOLIN, 2001, p. 11, grifo nosso)

Huizinga define as características fundamentais do jogo, tal como é expresso "pelas palavras mais comuns na maior parte das línguas europeias modernas" (2004, 33), reforçando os aspectos da ação voluntária, das delimitações de tempo e espaço, da ordem estabelecida pelo cumprimento das regras, da situação não cotidiana, e apresenta novos elementos, a tensão e a alegria:

O jogo é uma atividade ou ocupação voluntária, exercida dentro de certos e determinados limites de tempo e de espaço, segundo regras livremente consentidas, mas absolutamente obrigatórias, dotado de um fim em si mesmo, acompanhado de um sentimento de tensão e de alegria e de uma consciência de ser diferente da "vida quotidiana". (2004, p. 33)

Entendendo a palavra tensão no sentido de se colocar todo o corpo e o espírito em estado de alerta, em preparação, em atenção, e não em seu sentido comum que denota rigidez, encontramos também presentes esses dois novos aspectos no Curumim. Spolin não usa o termo tensão, mas fala da presença, do estar no aqui e agora, atributo alcançado ao focar os objetivos específicos do jogo, a entrega ao ato de jogar, excluindo as preocupações individuais com a própria performance ("como estou me saindo?"), escapando do confinamento da própria cabeça (SPOLIN, 2001, p. 18).

Nas atividades artísticas, esse elemento - a presença - é fundamental, perseguido e de difícil manutenção, é a expressão do eu profundo, intuitivo, distante

\footnotetext{
152 Os jogos geralmente eram bem aceitos, mas às vezes não o eram por algumas crianças que não queriam participar pelos mais diversos motivos, desde não ter gostado da atividade até para ser "do contra". Nesses casos, nossa opção era sempre a de não forçar as crianças a jogar (mesmo porque, na medida em que o jogo se torna obrigação, perde uma das principais características, ou seja, já não podemos mais chamar de jogo!), ou mudando de jogo ou atividade se o número de crianças "indisponíveis" era alto a ponto de comprometer todo o grupo.
} 
dos disfarces da personalidade convencional: "A presença chega através do intuitivo. Não podemos aproximar a intuição até que estejamos livres de opiniões, atitudes, preconceitos e julgamentos." (SPOLIN, 2001, p. 18).

Além das características, conceitos e funções do jogo, encontramos, no texto de Huizinga, sensações que pertencem ao universo lúdico, além das já apresentadas (tensão e alegria), tais como prazer, divertimento, intensidade, paixão, fascinação; palavras que evocam movimento, como vivacidade e $\underline{\text { ritmo; }}$ e outras que evocam a beleza, como graça. Assim como Spolin, o autor também constata a presença: "Todo jogo é capaz, a qualquer momento, de absorver inteiramente o jogador." (HUIZINGA, 2004, p. 4-13).

Ao sublinhar os aspectos lúdicos que permearam o Curumim, percebemos que muitos desses aspectos são inerentes à própria atividade coral, sobretudo no coro infantil, ou pelo menos assim deveriam ser. Percebemos também que esses aspectos foram reforçados pela escolha em adotar estratégias lúdicas para transmitir e informar, caracterizando uma ação pedagógica e, por isso, nos serviremos das reflexões da educadora Spolin na sistematização das atividades lúdicas que discutiremos mais adiante.

\subsection{Desenhando os Momentos do Ensaio}

A atividade coral se dá em grupo, e o jogo da convivência nas poucas horas semanais é um processo de harmonização, de afinação entre sintonias e dissonâncias, em contínuo movimento, trabalho coordenado pelo maestro. Aqui entendemos a função do maestro como Spolin define a do diretor como instrutor, "o agente catalisador, que procura canalizar as energias de pessoas diferentes para uma ação unificadora." (2001, p. 24).

Dentro das condições favoráveis para o trabalho de canto coral infantil, existia a preocupação com o ambiente, tanto no sentido físico-espacial, como no sentido psicológico, das expressões humanas. Assim como é ideal ter uma sala de ensaio 
adequada aos pequenos e à atividade musical ${ }^{153}$, é também necessário criar condições para que o ambiente social seja "amplo" e propício, permitindo a expansão das expressões humanas de maneira respeitosa e condizente com os objetivos do grupo.

A maneira apaixonada, sem perder os objetivos de vista, com que a mestranda e sua assistente Claudia Regina Costa conduziam o grupo foi fundamental para o estabelecimento dessas condições, para buscar e manter as crianças interessadas no grupo e em seus objetivos musicais e, assim, fazer com que respeitassem voluntariamente as regras do jogo coral. Spolin (2001, p. 27) aconselha os diretores, dizendo que "nunca, nem por um só momento, você deve mostrar cansaço ou tédio, pois o diretor sem energia causa mais dano ao espetáculo do que se pode imaginar.".

Com exceção dos grupos que foram se estabelecendo a partir de 1999, como descrito no capítulo I, precisávamos, a cada início de ano letivo, criar o grupo, pois o que tínhamos eram adultos e crianças ocupando o mesmo espaço e pais curiosos, alguns ansiosos, do lado de fora da sala. Os objetivos comuns eram vagos para os curumins: algumas crianças não tinham a menor ideia do que aconteceria ali, enquanto outras tinham apenas ouvido, dos pais, que iriam cantar; raras já tinham tido alguma experiência com grupos musicais e excepcionalmente apareciam aquelas com experiências corais anteriores.

Cada grupo é um grupo, e cada primeiro encontro de grupo foi diferente devido às características próprias de seus componentes. No início dos trabalhos corais, a mestranda era impaciente e procurava organizar, à sua maneira, as crianças, impondo sua vontade. Com a prática, percebemos a inutilidade dessas ações, visto que as crianças continuavam a fazer o que queriam ou ficavam murchas, sem energia ou vontade, enfraquecendo a presença de si mesmas, de suas vozes, de suas expressões. Com a ajuda de Claudia Regina, um ser grupal por excelência, aprendemos pouco a pouco a lidar com a situação.

Nos últimos anos da nossa prática, os ensaios demoravam mais tempo para se organizar, até que as regras fossem compreendidas e aceitas; mas, quando,

\footnotetext{
${ }^{153}$ Nesse sentido, éramos privilegiados pelo trabalho da educadora Montessori, que deixou suas marcas nas atividades infantis desenvolvidas na Itália. Nossos espaços eram adequados às crianças, com cadeiras pequenas e com a possibilidade de decorar as paredes com as produções das crianças (desenhos, partituras, gravuras etc.). Na escola // Classico e na SU, contávamos também com o piano na sala.
} 
finalmente, era estabelecido o diálogo e as crianças eram "tocadas" pela magia de se cantar em conjunto, as necessidades inerentes ao canto coral organizavam o caos dos primeiros encontros.

À medida que o grupo se organizava, eram estabelecidas etapas básicas nos ensaios:

1. Recepção das crianças. As crianças são recebidas com um jogo, geralmente uma canção de roda, uma atividade de conscientização física ou uma brincadeira proposta por elas.

2. Aquecimento vocal. Nesse momento, são desenvolvidas brincadeiras atinentes à técnica vocal.

3. Aprendizagem de uma nova canção, quando utilizamos as atividades lúdicas específicas para o repertório.

4. Introdução a conceitos musicais, como definição e vivência dos parâmetros sonoros, e elementos para a compreensão da notação musical e leitura das partituras.

5. Repasse do repertório, quando também são propostas atividades lúdicas específicas para ele.

O esquema acima era o modelo de um ensaio padrão, alterado de acordo com os compromissos do grupo (ensaios gerais para apresentações; necessidade de aprofundamento de alguma canção que podia ocupar o ensaio inteiro; atividades de escuta musical, tais como peças de apoio ao repertório ou de ajuda ao crescimento musical; conversas etc.). Em cada um dos momentos de ensaio delineados eram inseridas atividades lúdicas, exemplificadas neste estudo.

A ordem desses momentos também podia variar, de acordo com as urgências e com o clima do grupo; e observamos, na prática como um todo, a constância dos itens 2 e 5.

À diferença de Spolin, que sistematiza seus jogos de acordo com os períodos de ensaio (etapas do processo de construção da cena), optamos por organizar os nossos de acordo com o modelo acima estabelecido. Essa escolha se deve ao fato de que nossos jogos foram elaborados para resolver problemas corais específicos, e 
porque nem sempre sabíamos, ao início do trabalho, quais eram os concertos, quais eram as músicas que seriam feitas, e estávamos abertos às propostas que surgiam durante o percurso: elementos surpresas mudavam a rota da nossa programação inicial, criavam desvios por outras veredas.

O objetivo de Spolin é construir a cena teatral, utilizando os jogos para as necessidades específicas dessa cena; nosso objetivo foi o de construir um grupo apto a cantar em conjunto um repertório multicultural, por meio de ensaios permeados de atividades lúdicas dirigidas ao desenvolvimento dos saberes atinentes à produção coral.

Em nossa divisão, podemos abranger os vários aspectos necessários à produção coral: trazer as crianças para o momento do ensaio, trabalhar a técnica vocal, ensinar as canções do repertório, oferecer elementos para a compreensão dos parâmetros sonoros, lapidar e/ou recordar canções. Com as atividades lúdicas, a consciência de grupo e a cooperação mútua também se desenvolvem.

\subsection{Colorindo o Desenho}

As atividades lúdicas apresentadas a seguir estão agrupadas de acordo com o modelo dos momentos de ensaio expostos anteriormente. São, em sua maioria, jogos elaborados para o desenvolvimento de habilidades e conhecimentos técnicos musicais. $\mathrm{Na}$ contextualização de algumas canções, usamos elementos narrativos e teatrais, tais como histórias e sua encenação, exemplificados nas canções Bella Ciao, Das Klinget so Herrlich e Mekô Merewá.

Os exemplos de atividades lúdicas aqui expostas são fruto da prática do Coro Curumim e das reflexões deste estudo no sentido de sistematizar e adequar essas atividades para serem usadas por coros infantis brasileiros, de servir como inspiração para elaboração de novas atividades e variantes, ou ainda para a realização dessas atividades segundo nossas indicações.

$\mathrm{Na}$ organização dos relatos dos jogos, fomos inspirados por Spolin, adotando os itens por ela elaborados no livro que estamos usando como apoio, sobretudo o foco, 
a descrição e as notas. Acrescentamos também os itens material a alguns jogos, devido ao uso de objetos; posição, para determinar, no início do jogo, se as crianças estariam sentadas, em círculo, semicírculo, em pé etc.; e objetivos, por dizerem respeito aos principais aspectos trabalhados no jogo.

Em alguns momentos, os itens foco e objetivos se assemelham, mas a diferença é que o foco é o elemento central do jogo, que deve ser observado pelos jogadores, enquanto objetivos são os problemas a serem resolvidos e conceitos a serem transmitidos.

\subsubsection{Recepção das crianças}

O momento da recepção das crianças assemelha-se ao aquecimento em Spolin (2001, p. 46): "os aquecimentos removem quaisquer distrações exteriores que os jogadores possam trazer consigo (...), os aquecimentos tornam tudo presente para todos. Eles ajudam a superar as diferenças pessoais." A autora também sugere, para o aquecimento, jogos tradicionais ${ }^{154}$, que também usávamos em nossas atividades, como a popular ciranda italiana Giro-girotondo.

Esse era o momento de trazer as crianças para o ensaio, para o conjunto, para o prazer do momento especial, diferente dos vividos na escola ou na família. As atividades lúdicas propostas nesse momento visavam, sobretudo, a diversão e a integração dos pequenos.

\footnotetext{
${ }^{154}$ No Brasil, encontramos canções tradicionais infantis estudadas, coletadas, arranjadas para coro etc. Dos estudiosos, sugerimos o Guia Prático de Heitor Villa-Lobos (com canções tradicionais arranjadas para canto orfeônico); os CDs de canções tradicionais da infância brasileira da musicóloga Lydia Hortélio (HORTÉLIO, 200?), com jogos, brincadeiras, contos e parlendas; o Folclore Musicado da Bahia (PEDREIRA, 1978), com partituras de canções e textos de contos; e o livro de partituras de canções tradicionais de Novaes (1986).
} 


\section{Brincadeira do banho}

Posição: sentadas no chão em círculo.

Foco: lavar as partes do corpo indicadas pelo instrutor.

Descrição:

1 - O instrutor convida as crianças a tomarem banho.

2 - Com um sabonete imaginário, cada criança "lava" seu próprio corpo dos pés à cabeça, segundo as indicações do instrutor.

Objetivos:

- Reconhecer as várias partes do corpo.

- Concentração, obtida na atenção das instruções.

Notas:

Essa brincadeira pode ser enriquecida se, após o convite "Vamos tomar banho?", estimularmos as crianças, perguntando como elas tomam banho. A partir dos elementos que trouxerem (banheira, ducha, sabonete, xampu, cremes, água quente, gelada etc.), o instrutor os incorpora à brincadeira e direciona as partes do corpo a serem limpas. Em um grupo, as crianças quiseram cantar debaixo do chuveiro!

Quando a brincadeira é realizada dessa maneira, as crianças encontram um momento de compartilhar parte de suas vidas e de se expressarem verbalmente, e assim podemos abrir um espaço de conversa.

\section{Gepetto e Pinocchio}

Posição: deitadas no chão.

Foco: mover apenas as partes do corpo solicitadas.

Descrição: 
O instrutor será Gepetto e as crianças serão Pinocchio. As crianças ficam deitadas no chão, e a parte do corpo em que Gepetto põe a mão e indica que tem vida elas podem mover. $\mathrm{O}$ jogo termina quando várias partes do corpo foram tocadas e as crianças podem sair andando imitando o boneco de madeira.

Objetivos:

- Concentração.

- Conscientização corporal.

Notas:

Nas repetições da brincadeira, o instrutor pode ficar de fora e deixar a cargo das crianças a escolha de Gepetto. A experiência mostra que vários ensaios serão ocupados com o jogo até que todos tenham sido Gepetto.

Esses personagens também são conhecidos pelas crianças aqui no Brasil e, se for realizado em um grupo que desconheça o velhinho carpinteiro e seu filho de madeira, é necessário preparar o jogo contando essa história. A brincadeira na Itália foi aceita sem problemas por todos os grupos, porque esses personagens pertencem ao seu universo.

\section{Corre Cotia}

Material: lenço ou pedaço de papel amassado.

Posição: em roda, de mãos dadas.

Foco: cirandar no ritmo da parlenda "Corre Cotia".

Descrição:

Uma criança fica no lado externo da roda com um lenço na mão, andando em sentido contrário ao giro da roda, enquanto todos dizem a parlenda: "Corre Cotia, na casa da tia, corre cipó, na casa da vó, lencinho da mão, caiu no chão, moça bonita do meu coração." Quando as crianças terminam a parlenda, todos ficam parados esperando que a criança de fora da roda jogue o lenço (ou papel amassado) atrás de 
uma das crianças que estão na roda. Quando isso acontece, a criança que tiver o lenço atrás de si deve pegá-lo e sair correndo atrás da outra, por fora da roda. Se quem jogou o lenço conseguir ocupar o lugar da criança antes que esta o pegue, a brincadeira continua com quem está com o lenço nas mãos; caso contrário, é escolhida uma nova criança para ficar fora da roda.

Objetivos:

- Concentração.

- Conscientização rítmica - cirandar marcando o passo na pulsação da parlenda.

Notas:

Aqui no Brasil, essa brincadeira de roda é bem conhecida, mas, na Itália, não. As palavras foram aprendidas enquanto cirandávamos. Numa das vezes em que a fizemos, sem querer começamos a cantar em vez de falar a parlenda, e acabamos criando uma melodia. Em seguida, uma das crianças fez "observações" vocais na canção apenas inventada, ou seja, improvisou uma nova melodia para a parlenda. Essas melodias sobrepostas resultaram em uma música estranha e a duas vozes, mas que as crianças cantavam todas as vezes em que repetíamos a ciranda.

\subsubsection{Aquecimento}

\section{Cheirando flores}

Posição: livre.

Foco: inspiração nasal profunda.

\section{Descrição:}

1 - O coordenador pede para as crianças fecharem os olhos e imaginarem uma flor bem cheirosa.

2 - Cada uma das crianças fará de conta que está sentindo o cheiro da sua flor. 
3 - O coordenador pergunta para cada uma das crianças qual o nome ou a descrição da flor que imaginou.

4 - O coordenador propõe sentir o cheiro de todas as flores colocadas.

Objetivos:

- Treinamento da respiração pelo nariz.

- Concentração.

Notas:

Usamos o jogo simbólico para trazer boa sensação ao inspirar, exercitando, assim, a inspiração profunda. Ao estimular as crianças a trazerem, pela imaginação, o que consideram um bom odor, observamos que respiram sem dificuldades, com prazer. Após a realização desse jogo, podemos remeter a essas sensações nos momentos do canto coral, por exemplo, quando percebemos que o legato de uma frase musical não se sustenta devido a bloqueios na inspiração. Esse jogo pode ser usado também para trazer tranquilidade quando as crianças estão muito agitadas.

\section{O sopro dos Três Porquinhos}

Posição: livre.

Foco: respiração: inspiração e expiração.

Descrição:

O coordenador conta a história dos três porquinhos, usando os momentos em que o Lobo Mau assopra as casinhas dos porquinhos, no sentido de passar os conteúdos de técnica de respiração: como inspirar sem levantar os ombros, assoprar fraquinho, médio e forte etc.

Objetivos:

- Treinamento das técnicas de respiração usadas para cantar.

- Concentração. 
Notas:

Esse conto também pode ser usado para reproduzir ritmos diferenciados, que o coordenador inventa ou pede paras as crianças inventarem e imitarem, no momento em que o Lobo Mau bate na porta de cada um dos porquinhos. Nesse exemplo, mantemos o foco na respiração ${ }^{155}$.

\section{Mamãe eu quero}

Material: diapasão.

Posição: coral.

Foco: emissão vocal.

Descrição:

1 - O coordenador canta: "Mãe eu quero cantar"

2 - O instrutor pergunta às crianças o que elas querem pedir para a mãe, e cada uma responde cantando a melodia proposta, alterando apenas a última palavra.

\section{Objetivos:}

- Aquecer a voz.

- Afinação.

- Memória melódica e criação.

Notas:

A canção foi inventada por Michel, um dos curumins, com a letra Mamma voglio cantar. Nós pegamos sua criação e fizemos as alterações descritas para virar um jogo.

Essa melodia simples pode ser feita como vocalise, que vai subindo de meio em meio tom, mantendo a palavra final improvisada pelos cantores:

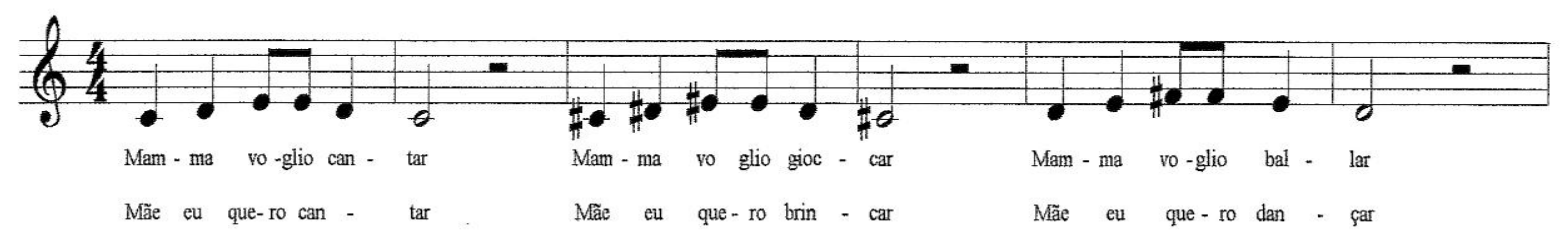

155 O objetivo aqui não era o de fazer uma história sonorizada e, sim, de usar elementos precisos da respiração. Para quem quiser inspiração em histórias sonorizadas, sugerimos os exemplos da Prof. ${ }^{a}$ Teca (BRITO, p. 163-172). 


\subsubsection{Introdução aos Conceitos Musicais}

No início desses estudos, e nas atividades com as crianças, dividimos os parâmetros sonoros de maneira tradicional: altura, intensidade, timbre e duração. Mas, ao cursar a disciplina Gênese da Notação Musical na Criança, nos deparamos com a necessidade de questionar essa divisão tradicional e, a partir dessas reflexões, buscarmos uma nova maneira de sistematizar as estratégias lúdicas realizadas.

Até hoje, a maioria dos livros sobre música divide os parâmetros sonoros como citado acima. J. H. Koellreutter acrescentava a essas qualidades a densidade ${ }^{156}$. Edgar Willems (1972, p. 57-58) sugeriu qualidades como clareza e pureza, e atentou ao fato de como alguns dos parâmetros podem se confundir:

Um som pode parecer mais agudo porque é mais forte ou tem um timbre mais claro. Em crianças, a confusão entre as várias qualidades às vezes é tão grande - um parâmetro é invariavelmente levado a outro - que seu progresso [na educação do ouvido musical] é comprometido. (WILLEMS, 1972, p. 57)

Sobre essa (con)fusão, Salles esclarece:

Essa "invasão" da intensidade, na área da altura e da melodia, ocorre em razão de uma conceituação natural das crianças, oriunda da linguagem comum, na qual "som alto" e "som baixo" não se referem, particularmente, nem à intensidade, nem à altura, mas à sua fusão. Assim, "som alto" é agudo e forte, e "som baixo" é fraco e grave. Não há dúvida de que a emissão vocal, mais uma vez, é uma das responsáveis por essa noção, na medida em que o esforço vocal para se chamar alguém ou para cantar "alto" supõe a elevação do som, tanto para o agudo quanto para o forte; ao passo que, num segredo, em que se deve falar "baixo", a voz é modulada para o fraco e igualmente para o grave. (1996, pg. 155)

Além disso, encontramos crianças que não queriam nem tentar cantar um lá 3 , porque ouviam a mestranda com seu timbre claro e imaginavam ser essa nota demasiado aguda! A confusão entre agudo $=$ forte, grave $=$ fraco; forte = rápido, fraco = lento, também tem a ver com a frequência das ondas sonoras, pois quanto mais agudo

156 "Parâmetro que se refere a um grupo de sons, caracterizando-se pelo menor ou maior agrupamento de sons num lapso, ou seja, pela rarefação ou adensamento". (BRITO, T. A., 2003, p. 19) 
for o som, maior é o número de vibrações por segundo. Nesse caso, tem-se a impressão simultânea de agudo-forte-rápido, e os sons graves são inversamente proporcionais, pois, quando a frequência sonora vai para regiões muito graves, torna-se ritmo, uma duração constante e lenta, até chegar ao silêncio para a percepção dos limites da nossa audição.

E o que falar sobre o silêncio? É ou não é um parâmetro sonoro? É um nãosom?

Aparentemente, só se pode caracterizar o silêncio pela duração, pois não parece ter nem intensidade, nem altura e tampouco timbre. Portanto, ele pertenceria a um âmbito não necessariamente musical, mas, sim, ao âmbito do tempo, da duração, do fundo onde os sons são desenhados. Veremos, entretanto, que o silêncio musical, e mesmo os silêncios não musicais, não são apenas duração, mas podem assumir uma infinidade de outras características, inclusive de altura, timbre e intensidade que são, mesmo, elementos constitutivos da poética e da estrutura musicais. Por isso, o silêncio é o infinito do som e não o zero. (SALLES, 1996. p. 17)

Salles cita exemplos em que os silêncios estão incorporados aos parâmetros sonoros:

\begin{abstract}
Vibrações cada vez mais lentas chegarão a um silêncio que poderá durar ao infinito; ao passo que vibrações cada vez mais rápidas se tornam a linha aguda até o infinito do inaudível, um silêncio do fisiologicamente possível. No ritmo, o silêncio cerca os sons, contorna os agrupamentos, delimita-os em ilhas; na densidade, há o silêncio relativo: aumenta o número de silêncios simultâneos, diminui a densidade do som; diminui o número de silêncios simultâneos, aumenta a densidade. Mas quem silenciou? O timbre. (1996, p. 174)
\end{abstract}

Na prática coral, o único desses exemplos de silêncio que não chega a tomar forma, dado o limite da tessitura vocal, é o que diz respeito às alturas. Mas na feitura dos ritmos, na densidade característica da simultaneidade da harmonia intercalada com momentos de polifonia, o silêncio assume qualidades sonoras.

Temos também o silêncio da respiração, "invocado na música por uma necessidade fisiológica" (SALLES, 1996, p. 175), fundamental nas atividades canoras, o silêncio do início e do fim do cantar, impregnados de intenções musicais. Temos também os silêncios sinalizados, na partitura, por pausas, cesuras, vírgulas, e que podem ou não atender às necessidades fisiológicas - se considerarmos que as capacidades respiratórias são diferentes em cada criança -, mas que trazem coesão ao 
discurso musical coral ao respeitarem o fraseado e intenções várias da obra; e a gama de silêncios que se vão construindo na pronúncia das palavras e que nos remetem ao silêncio como parte da intensidade: "o silêncio não é um nada, um nulo ou negação do som, mas, sim, algo que vai muito além de uma mera ausência." (SALLES, 1996, p. 175).

Salles considera a possibilidade de o silêncio estar ligado ao parâmetro intensidade:

Há uma forte relação entre a intensidade do som e sua presentificação. Talvez a intensidade seja, em função disso, um dos parâmetros mais próprios e característicos do som em si, pois determina, através de suas flutuações, a própria sensação (auditiva) da presença do som nos domínios do espaço e do silêncio. Aí, a intensidade se confunde com a própria vibração sonora, em que a noção de som forte e som fraco é análoga à de som e silêncio. (1996, pg. 142)

Discute-se também, se a duração seria ou não parte dos chamados parâmetros do som ou características do som, entendendo-a como categoria equivalente a altura, intensidade e timbre:

Se não definimos a duração como uma das características do som juntamente com intensidade, altura e timbre, como é usual, é porque ela não chega a ser uma característica intrínseca do som, não participando assim da constituição física de sua substância; quando se diz "o som dura tanto", é que se quer dizer que "intensidade, timbre e altura estão durando tanto", como todo e qualquer objeto, sólido ou não: se a duração caracteriza o som por sua instantaneidade e sua efemeridade, a mesma duração caracteriza, no outro extremo, as pedras por sua eternidade e sua permanência. Mas se a música está no tempo, propõe também percepções e ideias de tempo; ela, portanto, constrói e instaura tempos. (SALLES, 1996, p. 183)

O tempo é a casa da música, é um tapete onde são bordados os coloridos do som. As durações, por assim dizer, possibilitam que timbre, intensidade e altura deem formas aos retalhos e tramas que compõem esse tapete, permitindo diferentes construções com o material sonoro.

Com base nas reflexões acima, prosseguimos com exemplos de atividades lúdicas de conscientização dos parâmetros sonoros altura, intensidade e timbre, e da duração desses parâmetros no tempo e do silêncio. 


\subsubsection{Altura}

\section{Jogo dos graves e agudos sem frequência determinada}

Posição: dispostos em círculo (sentados no chão ou em cadeiras).

Foco: encontrar gestos próprios para expressar sons graves e agudos e decifrar os gestos dos colegas

\section{Descrição:}

1 - O instrutor pede um exemplo cantado de um som grave e de um som agudo. Se ninguém no grupo cantar os exemplos, o próprio coordenador os canta.

2 - O instrutor incita as crianças a encontrarem um gesto (ou movimento) individual para representar um som grave e um agudo.

3 - Enquanto uma das crianças, sem sair do seu lugar, "rege" as outras com seus próprios gestos, as outras interpretam esses gestos cantando os graves ou agudos.

4 - $O$ jogo termina depois que todas as crianças mostraram seus gestos.

Objetivos:

- Apresentar os conceitos grave e agudo.

- Incentivar a contribuição pessoal de cada criança para o grupo.

Notas:

1. É importante que o coordenador deixe claro no seu exemplo que "grave" e "agudo" não são conceitos absolutos, mas relativos: mais grave que..., mais agudo que..., embora haja extremos de altura e regiões relativas de altura.

2. O jogo pode continuar introduzindo o glissando entre os graves e agudos; pode-se eleger um gesto comum a todos e assim por diante. 


\section{Graves, médios e agudos com frequência determinada I}

Material: diapasão.

Posição: dentados em cadeiras.

Foco: na reprodução das alturas das notas, de acordo com os gestos estabelecidos.

Descrição:

1 - O instrutor, a partir da nota do diapasão, canta o fá 3 para as crianças.

2 - O instrutor e as crianças cantam juntos o fá 3.

3 - O instrutor pede para as crianças cantarem uma nota mais grave que a anterior.

4 - Cantar junto com as crianças os dois sons anteriores, determinando, com os gestos estabelecidos no jogo anterior, a nota grave e a nota aguda.

5 - Cantar outra vez a nota fá 3 e pedir um exemplo de uma nota mais aguda.

6 - Cantar junto com as crianças os dois sons anteriores, determinando, com os gestos, as novas notas grave e aguda.

7 - O instrutor canta sempre o fá 3 e as crianças cantam a notas estabelecidas, de acordo com a indicação do gesto representativo do grave ou do agudo.

Objetivos: mostrar a relatividade dos conceitos "grave" e "agudo", buscar a afinação.

Notas:

1. As crianças podem ir à frente do grupo e reger as outras.

2. Dentre os exemplos propostos pelas crianças, o coordenador precisa escolher intervalos que sejam exequíveis pelo grupo.

\section{Graves, médios e agudos com frequência determinada II}

Material: diapasão.

Posição: sentados em cadeiras, em suas posições corais. 
Foco: bater o número de palmas correspondente a cada nota musical.

\section{Descrição:}

1 - O instrutor, a partir do diapasão, canta o do 3, o fa 3 e o do 4 para as crianças.

2 - $O$ instrutor pede às crianças para baterem palmas uma vez, se a nota que cantar for grave; duas vezes, se for média; e três vezes, se for aguda.

Objetivos:

- Mostrar a relatividade dos conceitos "grave" e "agudo".

- Desenvolver a percepção sonora.

\section{Nome das notas}

Material: diapasão.

Posição: sentados em cadeiras em suas posições corais.

Foco: reproduzir a nota da escala correspondente à sua vez de cantar.

Descrição:

1 - A partir da nota lá 3 do diapasão, o instrutor canta a escala com os nomes das notas.

2 - Todos cantam a escala ascendente e descendente com os nomes das notas.

3 - Uma criança começa com o do e a que estiver do seu lado esquerdo prossegue com

a nota seguinte, e assim por diante até completarem a escala ascendente e descendente.

Objetivos:

- Exercitar o conhecimento e a memorização dos nomes das notas no contexto da escala, na forma ascendente e descendente.

- Desenvolver a afinação dentro da escala de Dó M. 


\subsubsection{Intensidade}

\section{Jogo do Regente Coral}

Posição: em semicírculo, sentadas nas cadeiras, com o regente infantil à frente.

Foco: nos gestos do regente infantil.

Descrição:

1. O instrutor prepara a atividade, pedindo exemplos de sons fortes e fracos.

2. O instrutor convida uma das crianças para reger as outras.

3. O regente infantil é instruído a usar apenas gestos para pedir sons fracos ou fortes, sem usar a palavra!

3. Ao terminar, essa criança convida outra para entrar em seu lugar como regente e dar continuidade ao jogo até que todos os coralistas tenham sido regentes.

Objetivos:

- Incorporar (trazer para o corpo) esses conceitos.

- Concentração nos gestos do colega.

\section{Notas:}

1. As crianças que têm ideia do que é um som forte e fraco, ao dar o exemplo, ensinam as que não sabem, criando uma linguagem comum. A partir desses exemplos iniciais, cabe ao instrutor tecer observações e orientações sobre eles, tais como forte, mas sem gritar; fraco, mas audível etc.

2. Ao assumirem a função de regente e se expressarem com gestos, as crianças incorporam a noção de forte e fraco. Em italiano, essas são as mesmas expressões usadas na música ocidental: forte e piano. Sugerimos, para coros brasileiros, que, ao término da atividade, o instrutor diga às crianças que, dali em diante, será usada a palavra piano para definir sons fracos. 
3. Aqui usamos o jogo do regente coral para trabalhar com um parâmetro sonoro específico, mas esse mesmo jogo foi usado também com outros parâmetros e na regência de algumas canções simples no último grupo do Curumim.

\subsubsection{Timbre}

\section{Jogo da Cabra-Cega}

Posição: em círculo, sentadas no chão.

Foco: identificar o timbre do colega,

Descrição:

Uma das crianças do grupo é escolhida para ser a "cabra-cega". É afastada do grupo e seus olhos são vendados. Uma das crianças que estão no círculo é escolhida para decidir qual música será cantada e dirá sua escolha ao ouvido do instrutor. Este dirá ao grupo qual música foi escolhida e todos a cantarão. Depois, a música será cantada pela criança que a escolheu, em solo, e a "cabra-cega" terá que adivinhar qual criança a cantou. $O$ jogo prossegue com a escolha de uma nova "cabra-cega" e de outra criança que escolhe a música a ser cantada.

Objetivos:

- Desenvolvimento da percepção musical, percepção de timbres de voz e reconhecimento de colegas.

- Concentração.

- Memorização do repertório.

- Desenvolvimento de autonomia musical. 


\subsubsection{Duração}

\section{Caminhando a Canção}

Material: piano.

Posição: em pé.

Foco: caminhar no andamento da canção.

Descrição:

1. O instrutor ou seu auxiliar escolhe uma canção do repertório para tocar no piano, mudando de andamento durante a execução.

2. As crianças são orientadas a caminhar conforme a música.

Objetivos:

- Trazer para o corpo as mudanças de andamento.

Notas:

1. O piano pode ser substituído por qualquer instrumento ou pode ser usada uma gravação de músicas com andamentos diferentes.

2. Em nosso caso, devido ao pouco tempo que durava cada encontro com as crianças, preferíamos usar canções do nosso repertório. Geralmente, depois dessa atividade, as crianças pediam para cantar a música empregada no jogo e usávamos esse momento de canto coral para também variar o andamento com gestos de regência, no decorrer da canção. 


\subsubsection{Silêncio ${ }^{157}$}

\section{Estátua silenciosa}

Material: piano.

Posição: em pé.

Foco: manutenção do silêncio.

\section{Descrição:}

1. As crianças são instruídas a andarem, enquanto o instrutor toca a canção ao piano, e a pararem feito estátuas ao ouvirem o silêncio.

2. Quando alguma das crianças emite um som qualquer, o instrutor volta a tocar. Objetivos:

- Despertar a audição do silêncio.

Notas:

1. O piano pode ser substituído por qualquer instrumento ou gravação.

2. O instrutor pode lembrar as crianças de que estátua não se mexe, nem fala!

3. Em nossas atividades, sempre havia alguma criança que falava, ria, suspirava, de maneira que logo voltávamos a tocar.

4. Se a duração do silêncio for muito pequena, o instrutor pode pedir às crianças para tentarem permanecer como estátuas o máximo de tempo possível.

157 Esse exercício é dirigido para atividades musicais, mas a observação do silêncio também é fundamental no convívio social. Nos espaços que criávamos para conversas, e às vezes durante o ensaio das músicas, algumas crianças falavam juntas, sem respeitarem a fala umas das outras, sem ouvirem o companheiro. Para tentar resolver esse problema, contávamos histórias que mostravam o valor do silêncio para ouvir o outro e ser ouvido. 


\subsubsection{Atividades Lúdicas Dirigidas ao Repertório}

Neste item, colocamos dois momentos do modelo de ensaio: o momento do ensino de uma nova canção e o de repasse do repertório. Trouxemos um exemplo de atividade lúdica para cada canção analisada neste trabalho, elegendo, em cada exemplo, um aspecto do trabalho coral: contextualização da letra e apresentação da canção, resolução de problemas técnicos inerentes à peça, memorização da canção etc.

Para a organização desta parte, elencamos as canções em ordem alfabética, seguidas de seus respectivos jogos. A última atividade apresentada será a de repasse do repertório.

\section{Bella Ciao}

Para contextualizar essa canção no Brasil, elaboramos um conto ${ }^{158}$ sobre um jovem italiano, uma moça e Mussolini. Ao fim da história, a canção é cantada pelo instrutor $^{159}$.

\section{Bigodão, Carlotta e Carecão}

Era uma vez um jovem italiano forte e bigodudo, uma moça de tranças inteligente e divertida, e um homem bravo, careca e rechonchudo.

${ }^{158} \mathrm{Na}$ Itália usamos esse mesmo recurso, elaborar uma história, para introduzir a canção La Lune est Morte, a preferida da nossa curuminha Carlotta Broglio.

159 Nossa grande inspiradora de histórias, ou melhor, estórias (como ela prefere) é a Prof. a Regina Machado, atualmente aposentada pelo o departamento de Artes Plásticas da ECA-USP, com quem a mestranda estudou e trabalhou em seu grupo de contadores de história e músicas, o Pé de Palavra. 
Bigodão, como era conhecido o jovem, era gente boa e apaixonado pela garota Carlotta, que trabalhava na lavoura de arroz.

Os dois sonhavam em se casar, construir uma casa colorida, ter filhos e viver felizes para sempre. Mas, um belo dia, nem tão belo assim, um tal de Mussolini, o carecão barrigudo, quis obrigar Bigodão a lutar na II Guerra Mundial.

Muita gente achava besteira aquela guerra inventada pelo amigo alemão do careca italiano, inclusive Bigodão e Carlotta. Então, o jovem resolveu "dar um chapéu" no careca e participar de um grupo de pessoas, os partigiani, que também não aceitavam ordens do gorducho.

O gordinho era terrível! Mandava todo mundo pra guerra enquanto ficava em casa no bem bom, lustrando as botas e a careca...

E assim foi Bigodão viver e lutar em companhia dos partigiani. Mas, num dia tenebroso, eis que o jovem acordou e encontrou um invasor: era um soldado do careca italiano bravo rechonchudo, vestido com uma camisa preta. Bigodão saiu correndo e conseguiu fugir do soldado, mas foi atingido em seu peito por um tiro de revólver.

Quando seus amigos partigiani o encontraram, os fartos pelos de seu bigode estavam murchos, e o moço estava à beira da morte. Carlotta foi avisada e veio voando ao encontro de seu amado. Ao vê-la, seu bigode voltou ao normal, arredondando suas pontas enquanto cantava para sua namorada e os amigos sua história:

Una mattina, mi son svegliato, oh bella ciao, bella ciao, bella ciao, ciao, ciao...

\section{Cuckoo!}

Para essa canção, além da atividade lúdica de contextualização, foram necessárias diversas atividades de técnica vocal, para atingir os objetivos musicais, tais como a realização dos pp e ppp, do stacatto, do marcatto, do legato de frase sul fiato e das notas agudas. Aqui apresentamos a atividade dirigida ao trabalho do stacatto e do marcatto. 


\section{Cuco com Soluço}

Posição: sentados em cadeiras, em suas posições.

Foco: adivinhar quem é o cuco com soluço.

Descrição:

A atividade consiste em dois momentos: no primeiro, é pedido às crianças que imitem sons de passarinhos que conhecem. Ao aparecer o som do cuco (e, se não aparecer, o próprio instrutor propõe este som), pede-se a todas as crianças que reproduzam o som do cuco, mas da maneira que costumam fazê-lo (sem imitar a primeira ocorrência).

Este som é trabalhado da forma como a música pede, ou seja, a sílaba "Cuc" em stacatto e a sílaba "koo" em marcatto, respeitando a terça $M$ descendente, mas sem uma nota de partida comum e respeitando a rítmica da peça. Para facilitar a execução do stacatto, é dito às crianças que o cuco está com soluço, que lhe acomete sempre no início do canto, e que é por isso que faz mais forte a segunda sílaba.

Em um segundo momento, uma das crianças deve se afastar do grupo, ficando de costas, enquanto outra é escolhida para ser o cuco. Se a primeira criança acertar quem é o cuco, elas trocam de lugar; se isso não acontecer, o jogo prossegue mudando os "cucos" até que a primeira criança adivinhe de quem é a voz.

Objetivos:

- Trabalhar o stacatto e o marcatto da canção.

\section{Das Klinget so Herrlich}

Apesar de ser uma música conhecida para os italianos curumins, relembramos, em palavras simples, a história central da Flauta Mágica. Mesmo sendo conhecida 
também aqui no Brasil, sugerimos ao instrutor elaborar, com suas próprias palavras, um resumo da ópera para contar às crianças ${ }^{160}$.

Depois dessa aproximação à ópera, falamos que, nessa canção, Papageno (o homem que se vestia de penas) e Pamina (a princesa por quem Tamino era apaixonado) escaparam de Monostatos e seus escravos, porque, quando Papageno toca o carrilhão, os malvados começam a dançar e cantar alegremente, deixando Pamina e Papageno escaparem. Assim podemos introduzir a atividade.

Material: piano, folhas de sulfite e lápis coloridos.

Posição: em mesas ou no chão.

Foco: desenho da cena de Das Klinget so Herrlich.

Descrição:

1. O instrutor, depois de contar a história da Flauta Mágica e de falar sobre o que acontece na parte da canção Das Klinget so Herrlich, pede às crianças que desenhem esse momento.

2. Enquanto as crianças desenham a cena, o instrutor toca ao piano (e/ou canta), com acompanhamento harmônico, as três linhas melódicas dos naipes.

Objetivos:

- Interiorizar a história usando a narrativa e a criação de um desenho.

- Preparar o ensino da canção com as linhas melódicas tocadas ao piano, em contexto harmônico.

160 Como exemplo, deixamos aqui nossa maneira de contar: A flauta mágica é uma história que conta o amor entre um príncipe, Tamino, e uma princesa, Pamina. Tamino se apaixona por ela quando vê seu retrato mostrado pela mãe, a rainha da noite, que pede para resgatá-la, pois foi raptada pelo grande sacerdote, que a mantém presa. Pra ajudar Tamino, a rainha manda seu empregado, Papageno, um cara engraçado todo vestido de penas, acompanhar o príncipe na busca da sua filha Pamina, e dá de presente pra Tamino uma flauta mágica e, pro Papageno, um carrilhão (glockenspiel). Acontecem muitas aventuras e desventuras no desenrolar da história, mas o final é feliz porque Tamino se casa com Pamina, Papageno encontra uma Papagena e fazem muitos Papageninhos, e todo o reino vive feliz sob um luminoso Sol. 
Notas:

As crianças estarão concentradas no desenho, mas assim mesmo ouvirão a música sendo tocada ao piano. Ao trabalhar a peça, posteriormente, as melodias já serão familiares às crianças.

\section{Mekô Merewá}

Elaboramos esse jogo no laboratório de férias Lendas e sons amazônicos, descrito no capítulo I (p. 57), para crianças de diversas idades e, em grande parte, sem experiência musical. Trouxemos o jogo também para os grupos iniciantes do Curumim, usando-o como um momento de relaxamento nos coros avançados.

\section{A Onça e o Jabuti}

Posição: inicialmente livre. Na segunda parte do jogo, ocupando a posição dos jabutis ou da onça.

Foco: atenção à posição da onça para responder ao seu chamado.

\section{Descrição:}

Na primeira parte do jogo, conta-se a história da onça e do jabuti, inserindo elementos do cotidiano das crianças na história, ficando a critério da sensibilidade do instrutor para conhecer seu grupo. $O$ instrutor (regente, professor, colaborador) não precisa ser um contador de histórias, mas é necessário entrar na história que conta, saber inserir o universo de suas crianças nessa história e também integrar os comentários dos pequenos ouvintes durante a narração ${ }^{161}$.

${ }^{161}$ Para quem quiser se aproximar da arte de contar histórias, sugerimos o livro Acordais (MACHADO, 2003) e A Arte de Ler e de Contar Histórias (TAHAN, 1966). 
A história base ${ }^{162}$ é a da onça que desafia o jabuti para uma corrida e perde, devido à astúcia do último. A essência da história é que o fraco vence o forte pela inteligência e pela união solidária. Sugerimos que o instrutor, antes de contar a história, procure outras qualidades nos personagens, como, por exemplo, a arrogância, a ferocidade, a brutalidade, a prepotência, o individualismo e a força física da onça, em oposição à gentileza, à tranquilidade, à paciência, à humildade, à cooperação, à amizade, à astúcia e às limitações das habilidades físicas do jabuti. A partir desses e de outros atributos dos personagens, a história inicial é construída, e, na medida em que é contada, vão se inserindo as observações das crianças e elementos de seu cotidiano $^{163}$.

Depois desse primeiro momento, parte-se para o jogo.

$162 \mathrm{Na}$ época em que realizamos o jogo, a mestranda pensava que os personagens da história original eram esses, mas na verdade foi uma recriação da fábula de Esopo, A Lebre e a Tartaruga, onde substituímos a lebre pela onça e a tartaruga pelo jabuti. Encontramos, também, no livro Mitos Amazônicos da Tartaruga essa mesma essência no conto Como o Jabuti venceu o Veado na Carreira (HARTT, 1977, p. 57). Pedimos licença à tradição para mantermos os personagens da nossa recriação.

163 Em nossa história apresentávamos uma Onça que frequentava a academia o dia inteiro, só pra poder brigar à noite no bar, e o Jabuti caminhava horas e horas pra buscar água para sua família, e no tempo livre ia ao parque (ou um local que sabíamos que as crianças gostavam) passear com os amigos. Um dia, quando estava trazendo uma gota de orvalho pra casa, encontrou a Onça, que começou a caçoar dele, dizendo ao Jabuti que ele nunca chegaria em casa, pois era lento demais e que sua família morreria de sede de tanto esperar por ele. O Jabuti se sentiu mal (podemos usar como exemplo de bullying a atitude da Onça em relação ao Jabuti), mas prosseguiu sua jornada, caminhando lentamente em direção à casa, carregando a folha com a gota de orvalho sobre seu casco.

A Onça, que só sabia brigar, ficou furiosa com a falta de reação do Jabuti, e continuou a falar sem parar: você é lerdo, qua qua qua qua qua, você é cascudo, por isso que é pesado, e por isso que é lerdo, qua qua qua qua qua, você tem perninhas curtinhas e por isso é lerdo, qua qua qua qua...

De tanto ser provocado, e por ser lerdo mesmo e não conseguir sair correndo daquela situação, o Jabuti perdeu o controle e disse á Onça: "Ah, tá, sou lerdo? Então te desafio para uma corrida!" A Onça caiu na gargalhada e aceitou o desafio na hora. Marcaram um encontro no domingo de manhã e foram embora. (Aqui se pergunta às crianças onde o encontro foi marcado)

O Jabuti não conseguia descobrir sozinho um jeito de ganhar a corrida, então, no sábado à noite, encontrou com seus amigos jabutis e expôs a situação. Seus amigos encontraram uma saída e disseram que o ajudariam. Ficariam dispostos em diversos pontos do trajeto da corrida, enquanto o Jabuti não sairia do lugar da partida (e, portanto, do lugar da chegada). Todos sabiam que a Onça era desatenta e achava todos os Jabutis iguais, não enxergava sua individualidade. Por isso, a cada trecho do trajeto, não percebia que o Jabuti que a ultrapassava era sempre um jabuti diferente; e dessa maneira, o Jabuti venceu a Onça contando com a ajuda de seus amigos. 
1. O número ideal de crianças é de, no máximo, quinze participantes. Se o número de participantes for superior ao ideal, sugerimos a divisão em dois grupos, que se alternam em expectadores e atuantes.

2. Os jabutis formam um círculo no chão, assumem a posição de jabuti (a critério das crianças), deixando espaços entre uma criança e outra.

3. Na primeira rodada do jogo, o instrutor assume a figura da Onça, que canta Mekô Merewá andando em torno do círculo, na parte de fora. Quando termina a canção, pergunta: “Jabuti, onde você está?". E o primeiro Jabuti que está diante da Onça responde: "Estou aqui, na tua frente!". Então, a Onça troca de lugar com o Jabuti que respondeu, e esse Jabuti se torna a Onça, prosseguindo a brincadeira até que todos tenham passado pelos papéis de Onça e Jabuti.

\section{Notas:}

Deslocamos o sentido original de Mekô Merewá, no que diz respeito ao uso da canção na comunidade Paiter Suruí, seu aspecto religioso e a própria história que a contextualiza. Mantivemos apenas a figura da Onça (Mekô) e sua ferocidade. Nossa intenção aqui era a de trazer elementos da cultura indígena brasileira, ensinar a canção de maneira lúdica e integrar as crianças, mas não necessariamente de seguir um trajeto literal.

\section{N'Kosi Sikeleli Africa}

Para esta canção, com fonemas particulares e tão distintos das línguas latinas, foi elaborada uma atividade que ajuda a memorizar palavras e melodia. 


\section{Trem da canção}

Material: diapasão.

Posição: em pé, em fila, lado a lado.

Foco: na canção.

Descrição:

1 - O coordenador escolhe uma criança para ser a "locomotiva" e começar a brincadeira.

2 - A locomotiva começa a canção e, quando toca na criança ao lado, esta prossegue a melodia.

3 - Quando descarrilar o trem (ou seja, alguém esquecer a sequência, errar a letra ou a melodia), cantamos todos juntos essa parte (em auxílio ao esquecido), e prosseguimos o jogo.

Objetivos:

- Trabalhar a pronúncia.

- Memorizar a melodia principal da canção.

- Concentração.

Notas:

1. Essa mesma brincadeira pode ser realizada de outra maneira: a locomotiva canta a frase 1 , a criança do lado esquerdo canta a frase 2 , e assim por diante até que todas as crianças tenham cantado ao menos uma frase da peça.

2. Para facilitar o jogo, o instrutor pode dizer para cantarem mentalmente a canção, enquanto não chega a sua vez de cantar. 


\section{Tzun Tiãn Lai}

Nessa peça, não foi realizada nenhuma atividade lúdica com o Coro Curumim, mas a apresentamos em um laboratório de férias - Os cantos dos homens - (ver p. 58 e 59, capítulo I). Para cantá-la, confeccionamos leques de papel, nos quais as crianças desenharam flores, de acordo com o que sabíamos da canção até aquele momento.

Durante este estudo, descobrimos a poesia Gato da China, de José Paulo Paes (1991). Deixamos, como proposta lúdica, a leitura dessa poesia ${ }^{164}$, pelo instrutor, e o trabalho com os elementos da cultura chinesa encontrados nela, tais como as palavras Xangai, Rio Amarelo, Tinta Nanquin, Mandarin, Língua de Pau etc.

\section{Repasse do Repertório}

\section{Jogo da Memória das Canções}

Construímos cartões retangulares em que colamos figuras extraídas das partituras de Pomba Branca, N'Kosi Sikeleli Africa, Minha Canção, La gata y El belitre e II Treno (ver ANEXO YY). Desse modo, as canções são predefinidas pelo regente e o material chega pronto para ser posto em jogo, ocupando menos tempo de ensaio. Aqui sugerimos também outro jeito de se construir a atividade, em que a criança participa desde o início da elaboração do jogo.

\footnotetext{
164 "Era uma vez / Um gato chinês / que morava em Xangai / sem mãe e sem pai / que sorria amarelo / para o Rio Amarelo, / com seus olhos puxados, / um pra cada lado. / Era um gato mais preto / que tinta nanquin, / de bigodes compridos / feito mandarim, / que quando espirrava / só fazia "chin!" / Era um gato esquisito: / comia com palitos / e quando tinha fome / miava "Ming-au!" / mas lambia o mingau / com sua língua de pau. / Não era um bicho mau / esse gato chinês, / era até legal. / Quer que eu conte outra vez? " (PAES, 1991). Sugerimos o contato com o livro, disponível em diversas bibliotecas infantis, que apresenta uma bela ilustração feita por Luiz Maia.
} 
Material: folhas de papel sulfite, lápis de cor ou giz de cera, uma folha de cartolina, régua, colas e tesouras individuais com pontas redondas.

Posição: sentados em mesas ou espalhados pelo chão.

Foco: expressar no desenho a canção e relembrar o repertório musical.

Descrição:

Para que as crianças contribuam com seus próprios desenhos na construção do jogo, serão necessários, no mínimo, dois dias para essa atividade.

1. No primeiro dia, distribui-se o material de desenho e pede-se às crianças que desenhem sua canção preferida.

2. O instrutor recolhe os desenhos e, fora do ensaio, os reduz ao tamanho dos cartões retangulares que serão usados no jogo. No ensaio seguinte, traz, ao menos, três cópias em miniatura de cada desenho (duas serão usadas e uma fica de reserva).

3. No segundo dia da atividade, as crianças medem e cortam a cartolina para depois colarem seus desenhos reduzidos e duplicados.

4. Uma vez confeccionados os cartões, as crianças se sentam em roda e iniciam o jogo tradicional de memória.

5. Ao formar o par, a criança canta a música representada no desenho (ou o grupo todo canta, se alguma criança se sentir insegura em cantar sozinha).

Objetivos:

- Conhecer as preferências musicais das crianças.

- Fixar na memória o repertório musical.

Nota:

A mestranda faz o jogo de memória ainda hoje, com seus alunos de piano, substituindo as canções por figuras das notas e suas pausas, claves, posição das notas na clave etc.

Usamos, neste estudo, exemplos representativos da prática lúdica do Coro Curumim, no que diz respeito a elaboração de jogos, histórias e encenação delas dirigidas ao aprendizado do repertório multicultural e das habilidades musicais necessárias à interpretação desse repertório. Nem sempre eram usadas essas 
atividades, mas nossos encontros estavam permeados de características lúdicas, como o prazer, o divertimento, a intensidade, a paixão, a fascinação, a vivacidade, a beleza, a graça, a fruição etc.

As ações voluntárias delimitadas no tempo e espaço, a ordem estabelecida pelo cumprimento das regras numa situação não cotidiana, a presença (características intrínsecas ao ato de jogar), assim como a cooperação e a expressão individual dirigidas aos objetivos comuns, estavam presentes em nossas atividades cotidianas no grande jogo do fazer musical em conjunto. 


\section{CONSIDERAÇÕES FINAIS}

Neste estudo, trouxemos uma visão geral do trabalho desenvolvido com o Coro Curumim em Milão, pertencente à Associação Cultural Cantosospeso, pelo período de dez anos, relatando sua história contextualizada, discutindo os processos que envolveram a formação e a realização de um repertório multicultural de canções corais infantis, bem como as atividades lúdicas, que buscavam aproximar as crianças do cantar em conjunto, da percepção dos sons, da compreensão dos elementos musicais envolvidos e da própria dimensão cultural e social que esse repertório musical carregava.

Apesar das características específicas e singulares das experiências aqui relatadas, sobretudo no que diz respeito aos processos de análise, à escolha do repertório multicultural para canto coral infantil e às atividades lúdicas pedagógicas, pretendemos que elas possam servir de material de apoio a outros coros infantis, brasileiros ou não, ou como fonte de inspiração para trabalhos vocais e corais com crianças, que visem à reelaboração e adequação de suas práticas e concepções.

Ao longo da elaboração desta dissertação, notamos que o foco inicial de nossa reflexão, antes localizado nas atividades lúdicas, foi se expandindo, na medida em que tomamos consciência da importância que a própria história do Coro Curumim e seu contexto social e institucional assumiram para o trabalho. Do mesmo modo, a concepção de um projeto musical centrado em canções de diferentes culturas tomou vulto, já que propiciava, às crianças, ao regente e aos colaboradores, uma nova visão diante da música, e do próprio trabalho coral, que nos lança para o âmbito das relações interculturais, em que interferem valores como a ética, a tolerância, o respeito e o conhecimento do outro. Nesse sentido, foi importante nosso mergulho nas leituras e referências teóricas, assim como nos documentos que nos traziam de volta a experiência, modulada agora por novos conhecimentos, que demandavam e justificavam a sistematização dessa experiência e das análises.

Podemos considerar que nosso objeto de estudo era um organismo vivo, um todo de partes interligadas e em constante transformação, em que cada aspecto 
influenciava e modificava o outro: dependendo do grupo de coralistas, eram escolhidas as músicas, que, por sua vez, eram transmitidas e retrabalhadas por meio de atividades lúdicas, elaboradas, por sua vez, de acordo com as crianças de cada grupo. Estas cantavam tais músicas, preparavam-se para tais concertos e traziam seu feedback para novos cantares, em um processo de crescimento em espiral, resultante da integração desses vários aspectos, trabalhados e discutidos em cada encontro.

Com o relato e a discussão desse processo, almejamos compartilhar uma maneira - tão válida quanto tantas outras - de pensar e fazer o canto coral com crianças. Ao contar a história da Associação Cultural Cantosospeso e resgatar seus ideais sociais e musicais, com a ajuda da memória pessoal, de colegas da equipe de trabalho e de documentos, ao analisar as seis canções do repertório multicultural, ao procurar conceitos em bases teóricas que dialogassem com nossa prática, ao seguir indicações certeiras do nosso orientador, de professores e colegas, enfim, no processo deste estudo, encontramos as condições e práticas que caracterizaram o Coro Curumim.

Nosso coro foi resultado de uma prática lúdica, de cooperação entre crianças e adultos das equipes de trabalho, informando e transformando-se a cada passo, a cada ensaio, a cada apresentação. A opção pelo emprego de canções multiculturais no repertório abriu portas de reflexão para o diverso, para o outro, trazendo, para as crianças, a possibilidade do contato com várias culturas, línguas, sonoridades, estilos e épocas. Todas essas características se integraram e possibilitaram o momento mágico do fazer musical no canto coral infantil, mágica essa movida pela curiosidade, pela troca e pelo conhecimento.

Finalizamos com o depoimento de Carlotta Broglio (ver ANEXO ZZ), uma das "curuminhas" cantoras do nosso Coro Curumim, que, excetuando sua visão do público (que nem sempre era de apenas pais e parentes), resume e põe em perspectiva o que expusemos neste trabalho:

Muito tempo se passou desde que comecei a cantar no coro da Umanitaria [SU]. Apesar disso, tenho recordações claras e vivas daquela experiência. Além de recordar ainda hoje canções inteiras, como as aprendíamos, e as atividades que fazíamos durante as aulas, a coisa que mais me restou na alma é o sentido de pertencer a um grupo. O saber trabalhar em conjunto e ter de respeitar os outros. Cantar junto a várias vozes não era coisa fácil para crianças. Todos nós 
devíamos nos empenhar: se apenas um de nós errava, toda a canção vinha mal. Cada elemento do coro era importante. Juntos, conseguíamos realizar alguma coisa de mágico. Nós jogamos, aprendemos canções em línguas diversas, gravamos [um CD] em um verdadeiro estúdio de gravação e nos exibimos frequentemente ao público (os nossos pais e parentes, obviamente!), e tudo isso não seria assim tão belo se não fossem nossas duas educadoras: Claudia e Elisabet. Foi uma imensa alegria poder contatar Elisabet e saber que ela também se lembrava de mim e da minha paixão por uma canção do nosso repertório, La lune est mort. Com certeza, a experiência no coro contribuiu para me tornar aquela que sou hoje. Minha escolha de estudos é orientada ao mundo das Belas Artes e o coro provavelmente me ajudou a descobrir quem sou e o que quero fazer. (nossa tradução)

\section{$\cos 8$}




\section{REFERÊNCIAS}

\section{OBRAS CITADAS:}

ANDRADE, M. Dicionário Musical Brasileiro. Editora Itatiaia, Belo Horizonte, Rio de Janeiro, 1999.

ANDRADE, M. Pequena História da Música. Livraria Martins Editora S/A, 1980, 8ª edição.

ANDRADE, M.A. Avaliação em Canto Coral: Critérios e funções. In: HENTSCHKE, L.; SOUZA, J. Avaliação em Música: reflexões e práticas, editora Moderna, Ltda., São Paulo, 2003, p. 76-90.

BARBOSA, L.A. Resistência Cultural dos Judeus no Brasil. Dissertação de Mestrado em Ciências da Religião, Universidade Católica de Goiás, departamento de Filosofia e Teologia, 2006, p.13. Disponível em:

http://tede.biblioteca.ucg.br/tde_busca/arquivo.php?codArquivo=394. Acesso em 12 jun. 2013

BARRETO, C.M.B. Menina acanhada: uma tradução do Shijing. Pontifícia Universidade Católica do Rio de Janeiro.

BARICCO, Alessandro. Un pò d'Africa a Varese. In: Barnum 2 - Altre cronache dal Grande Show. Giangiacomo Feltrinelli Editore, Milão, Itália, segunda edição, 2000, p.4749.

BIANCHI, G.; BAGOZZI, A. Crescere con la Musica - Esperienze Cognitive e terapeutiche vissute in classe attraverso il linguaggio dei suoni, il movimento, il símbolo e il sonema, edizione Franco Angeli Libri s.r.l., Milão, Itália, 1984.

BRITO, T. A. Música na Educação Infantil. Editora Peirópolis, 2ª̣edição, 2003.

CANTOSOSPESO - Arte, Cultura e Solidarietà. Chi siamo. Disponível em: <www.cantosospeso.it>. Acesso em: 03 jun. 2013.

CASELLI, N. Manuale di Teoria Musicale. Collana Didattica CPM, edizione Nuova Carisch S.p.A., 1993, Milano, Itália.

CHAILLEY, J. A Flauta Mágica - Ópera Maçônica. Jorze Zahar Editor, Rio de Janeiro, 1994. 
FOLHA de São Paulo. Morre escritora argentina Maria Elena Walsh. In: Ilustrada, 10 jan 2011. Disponível em: <http://www1.folha.uol.com.br/ilustrada/857650-morreescritora-argentina-maria-elena-walsh.shtml>. Acesso em 15 maio 2013.

FOLHA DE SÃO PAULO. A Flauta Mágica. Coleção Folha Grandes óperas, volume 5, 2011.

FONTERRADA, M.T.O. De tramas e fios: um ensaio sobre música e educação. São Paulo: Editora UNESP, 2005.

FUCCI-AMATO, R. e GALATI, M. L. Do gesto à gestão - Um diálogo sobre maestros e liderança. inVersos Editora, São Paulo, Brasil, 2013.

GASPERETTI,M. II magistrato che cancella la parola extracomunitario. In: Corriere della Sera, Archivio Storico, 2011. Disponível em: $<$ http://archiviostorico.corriere.it/2011/settembre/08/magistrato_che_cancella_parola_ext racomunitario_co_9_110908037.shtml>. Acesso em 03 jul. 2012.

GRAZIANO, S. L. Oggi si canta. Casa Ricordi, Milano, 1999.

GRIFFITHS, P. A música moderna. Jorge Zahar Editor, Rio de Janeiro, 1987.

HARTT, C. F. Mitos Amazônicos da Tartaruga. Editora Perspectiva, 1977.

HUIZINGA, J. Homo Ludens. Editora Perspectiva S.A., 5ª edição, 2004.

IL LABORATORIO CORALE DI MILANO. II direttore. Disponível em: <http://www.illaboratoriocorale.it/il-direttore/> Acesso em 07 mai. 2013, tradução nossa.

KOELLREUTTER, H.J. Harmonia Funcional. Editora Ricordi, São Paulo, 1980.

LA GARZANTINA. Enciclopedia della Musica. Garzanti Editore, S.p.A., 1999, seconda edizione in 2002, Milano, Itália.

LAUAND, L. J. Deus Ludens - $O$ Lúdico no Pensamento de Tomás de Aquino e na Pedagogia Musical. Universidade de São Paulo, pág.1.

LANDON, H.C.R. 1791 - O último Ano de Mozart. Edição Nova Fronteira, 1990, Rio de Janeiro.

LEYDI, R. I canti popolari italiani. Arnoldo Mondadori Editore S.p.A., Milano, 1973.

LIMA, L. W. N. O Ensino de Mandarim no Brasil: Um estudo comparativo entre os sistemas pinyin e zhuyhin fuhao. Dissertação de Mestrado da FE-USP, 2012.

LISA, Mama. Chun Tin Dao - Chinese Nursery Rhyme. In: Mama Lisa's World International Music and Culture. Disponível em: 
$<\mathrm{http}: / /$ www.mamalisa.com/?t=es\&p=3741\&c=11\#multimediaBoxInternalLink>. Acesso em 11 jun. 2013.

MACHADO, R. Acordais. Editora DCL Difusão Cultural, São Paulo, 2003.

MAGRO,S. Africa: andata e ritorni. Giornale dell'Associazione Culturale Cantosospeso, numero uno, mag. 1997.

MARINI,G. I canti di lotta e di lavoro. Disponível em:

$<$ http://www.youtube.com/watch?v=nso6lpl1F4s\&feature=relatedrelated $>$.Acesso em 10 jan. 2013, tradução nossa.

Una mattina mi son svegliata - La musica e le storie di un'Italia perduta. Edizione Rizzoli, Milano, Itália, 2005.

MIRANDA, M. IHU - Todos os sons. Editora Terra, 1995.

MORAIS, D. V. O Material Concreto na Educaçãomusical Infantil: Uma Análise das Concepções Docentes. Dissertação de Mestrado, Escola de Música da Universidade Federal de Minas Gerais em Educação Musical. Belo Horizonte, 2009.

MATTOS, C. N. A tradução de cantos indígenas.in TUGNY, R. P. e QUEIROZ, R. C. Músicas africanas e indígenas no Brasil. Editora UFMG, Belo Horizonte, 2006, p. 173207.

MUNDURUKU, D. Histórias de Índio. Editora Schwarcz Ltda., São Paulo, Brasil, 1997.

NOVAES, I.C. Brincando de roda... Agir editora, 1986.

NURSERY RHYMES. Cuckoo, cuckoo, what do you do? Disponível em: <http://www.rhymes.org.uk/a19-cuckoo-cuckoo-what-do-you-do.htm>. Acesso em: 27 mar. 2005.

OLIVEIRA, M.L.G. VAMOS CANTAR, CRIANÇAS - Cancioneiro Volume I. Ministério da Saúde de Moçambique, Direção Nacional de Ação Social, Edição do Instituto Nacional do livro e do disco, Maputo, 1981.

PAES, J. P. Gato da China. In: Poemas para Brincar. Ilustrações de Maia, L., Editora Ática, 1991, 2ª edição.

PEDREIRA, E. Folclore Musicado da Bahia. Coleção Antonio Vianna, Salvador, 1978.

PIAGET, J. A formação do símbolo na criança. Zahar Editores, Rio de Janeiro, 1978.

PUCCI, M. D. Aspects of Paiter Suruí oral art. in: SCIELO, Vibrant: Virtual Brazilian Anthropology, On-line version ISSN 1809-4341, vol.8 no.1 Brasília Jan./Jun. 2011. Disponível em: <http://www.scielo.br/scielo.php?pid=S180943412011000100015\&script=sci_arttext>. Acesso em 18 jul. 2013. 
RAMOS, M. A. S. Referencial de Análise de Obras Corais. In: O Ensino de Regência Coral. Tese de Livre Docência apresentada à ECA-USP, 2003, São Paulo, Brasil, p. 7596.

REGIONE CALABRIA. Legge Regionale n. 4 del 08-01-1990. In: Scheda Sintesi e Testo Della Legge. Disponível em: <http://1.flcgil.stgy.it/files/pdf/19900108/calabrialegge-educazione-alla-pace-4-dell-8-gennaio-1990-3093883.pdf >. Acesso em 08 mai. 2013.

REVISTA FÓRUM. Ato em defesa de Dom Pedro Casaldáliga e do povo Xavante. Disponível em: <http://revistaforum.com.br/blog/2013/01/ato-em-defesa-de-dom-pedrocasaldaliga-e-do-povo-xavante>. Acesso em 11 jan. 2013.

SALLES, P.P. Gênese da Notação Musical na Criança. FEUSP, 1996. Dissertação de Mestrado.

SANTOS, K. B. O ideograma e a poesia concreta brasileira: um estudo de dois poemas de Haroldo de Campos. ReVeLe - no 2 - Jan. 2011, FALE/UFMG. Disponível em:

<http://www.letras.ufmg.br/cpq/revista\%20revele/revista_dois/KAROLINE\%20SANTOS \%200\%20IDEOGRAMA.pdf>. Acesso em 11 jul. 2013

SAHO. Enoch Mankayi Sontoga. In: South Africa History Online. Disponível em: <http://www.sahistory.org.za/people/enoch-mankayi-sontonga>. Acesso em 8 jun. 2013

SIMPÓSIO de história em Nova Olímpia. Biografia de Dom Pedro Casaldaliga. Disponívelem:<http://simposiodehistoriaemnovaolimpia.blogspot.com.br/2009/12/biograf ia-de-dom-pedro-casaldaliga.html>. Acesso em 11 jan. 2013.

SPADARO, A. Poesia Cinese: La parola come germoglio. In: SCUOLA CATTOLICA OGGI. Disponível em: <http://www.scuolacattolicaoggi.org/public/SCO/2008/09\%20\%20Settembre/01\%20-\%20Art.pdf>. Acesso em 11 jun. 2013.

SOUTH AFRICA. National anthem. in: South African Government Information. Disponível em: <http://www.info.gov.za/aboutgovt/symbols/anthem.htm>. Acesso em 5 jun. 2013

South African National Anthem, 1997. Disponível em: <http://www.info.gov.za/aboutgovt/symbols/anthem.pdf>. Acesso em 5 jun. 2013.

SPOLIN, V. O Jogo Teatral no livro do diretor. Editora Perspectiva, 2001.

TAHAN, M. A Arte de ler e de contar Histórias. Rio de Janeiro: Conquista, 1966.

TUTTITALIA.IT. Censimenti popolazione Milano 1861-2011. In: Lombardia, Milano, Censimenti 1861-2011, 2013. Disponível em: 
<http://www.tuttitalia.it/lombardia/18-milano/statistiche/censimenti-popolazione/>. Acesso em 03 jul. 2013.

WILLEMS, E. L'Oreille Musicale - Tome II - La culture auditive - Les intervalles et les accords, 3를 edition, Editions Pro Musica, 1972.

\section{AUDIOVISUAIS:}

YOUTUBE. Bella Ciao - originale. Nov. 2010. Disponível em: <https://www.youtube.com/watch?v=4Cl3lhyNKfo>. Acesso em 09 jul. 2013.

YOUTUBE. Cuckoo - Moonrise Kingdom. Maio 2012. Disponível em: <http://www.youtube.com/watch?v=e5ZwTYSo-aw>. Acesso em 09 jul.2013.

YOUTUBE. Schnelle Füße, rascher Mut... Das klinget - Röschmann, Keenlyside. Set. 2009. Disponível em: <http://www.youtube.com/watch?v=KrwcAqUEBJl\&feature=share>. Acesso em 09 jul. 2013.

YOUTUBE. Escolania Escorial: Das klinget so Herrlich. Flauta mágica (Mozart). Fev. 2010. Disponível em:<https://www.youtube.com/watch?v=jCdewcn8WOs $>$. Acesso em 09 jul. 2013.

YOUTUBE. Tzun Tiãn Lai. Jul. 2013. Disponível em: <http://www.youtube.com/watch?v=eswTsxXEYd0>. Acesso em 24 jul. 2013.

\section{DISCOGRAFIA:}

HORTÉLIO, L. Abra a roda tin dô lê lê. CD realizado por Brincante Produções Artísticas Ltda., 200?

Ô, Bela Alice... Música tradicional da Infância no Sertão da Bahia no Começo do século XX. CD realizado pela Microservice Tecnologia Digital da Amazônia Ltda., 200?

LUTERO, M.; CANTOSOSPESO. N'Kosi sikeleli Africa. In: Cantosospeso canta Bach e Afrika. 2005, faixa 1.

MIRANDA, M.; GRUPO BEIJO. Mekô Merewá. In: IHU - Todos os sons. 1995.

VILELA, I. Paisagens - 1998. Asa Branca, quinta faixa. Disponível em:<http://www.ivanvilela.com.br/disco/paisagens.html>.Acesso em 07 mai. 2013. 


\section{OBRAS CONSULTADAS:}

BENJAMIN, W. Reflexões: A criança, o brinquedo, a educação. Editora Summus, São Paulo, 1984.

Carvalho, V. A. Coral Cariúnas: identidade, significado e performance. Escola de Música da UFMG, 2007. Dissertação de Mestrado.

JOLY, I.Z. L. O coral infantil. In: Canto, canção, cantoria: como montar um coral infantil. SESC, São Paulo, 1997.

HAUCK-SILVA, C. Preparação vocal em coros comunitários: estratégias pedagógicas para construção vocal no Comunicantus: Laboratório Coral do Departamento de Música da ECA-USP. ECA/USP, 2012. Dissertação de Mestrado.

LOPES-GRAÇA, F. Breve ensaio sobre a evolução das formas musicais. In: Obras literárias: Opúsculos(1). Editorial Caminho,SARL. Lisboa, 1984.

MATEIRO, T. e ILARI, B. (orga.). Pedagogias em educação Musical. Ediitora IBPEX, Curitiva, $1^{\text {a }}$ edição, 2011.

MIOLI, P. Storia dell'opera lirica. Newton Compton editori s.r.l., Roma, 1994.

NATALE, M. Analisi musicale. G.Ricordi, Milano, 1992.

RAYNOR, H. Storia sociale della musica. Arnoldo Mondadori Editore, S.p.A.,1990.

SCHAFFER, M. O ouvido pensante. Editora UNESP, São Paulo, 1991.

SOARES, G. D. B. Coro infantil: uma proposta ecológica. Serra: Companhia Siderúrgica de Tubarão, 2006.

UTSUNOMYA, M. M. O regente de coro infantil de projetos sociais e as demandas por novas competências e habiliddes. ECA/USP, 2011. Dissertação de Mestrado. 
ANEXOS

Cap. 1 


\section{ANEXO A}

\section{Programa do Concerto Boas Festas}

\section{CORO VU' CANTA'}

Gruppo vocale costituito da cittadini extra comunitari, e' un'iniziativa congiunta dell'Associazione Culturale Cantosospeso e del COE (Centro Orientamento Educativo.) Fondato nel settembre 1992 dal maestro Martinho Lutero, suo attuale direttore, si dedica prioritariamente alla musica africana $\mathrm{e}$ latino americana, senza trascurare tutte le altre culture del cosiddetto" Terzo Mondo".

Ha debuttato ufficialmente nel Maggio Milanese 1993 eseguendo la "Missa dos Quilombos" di Milton Nascimento e Don Pedro Casaldaliga alla Basilica di San Lorenzo di Milano.

Attualmente ha in cantiere la prima esecuzione italiana della "Messa Luba", che sara' presentata nel Maggio Milanese 1994.

E' assistito dai capi sezione: Francesco Forges, Susana Alvear, Shinobu Kikuchi e dalla maestra Bett Just.

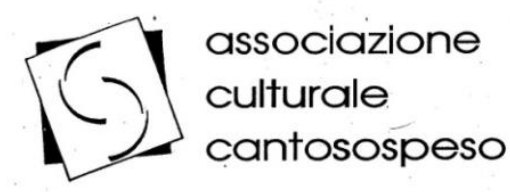

con la collaborazione del

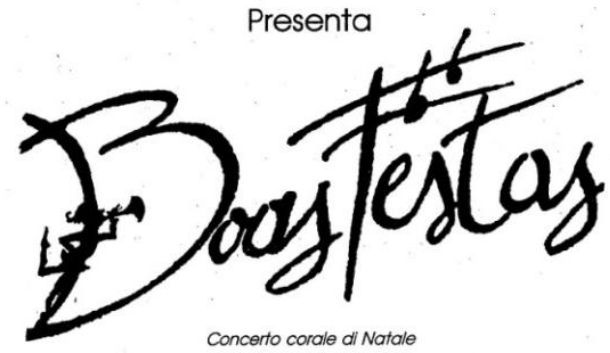

Direttore: Martinho Lutero

Auditorium San Fedele via Hoepli 3/B - Milano

Lunedì 20 Dicembre 1993 ore 21

\section{PROGRAMMA}

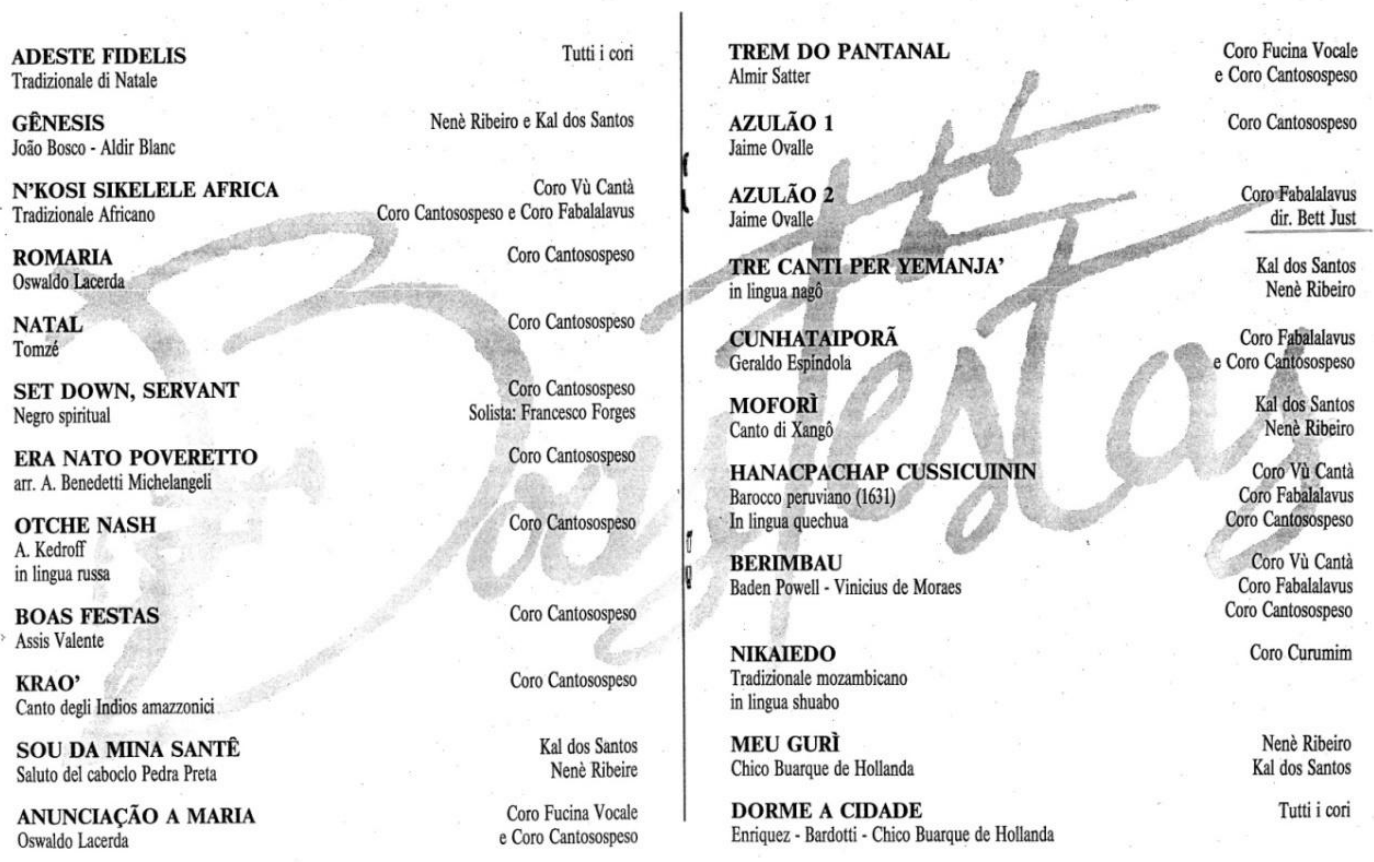




\section{ANEXO B}

\section{Programa do concerto SALUBA}

\section{COnO WU CANIN}

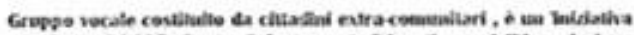

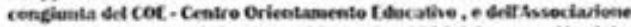

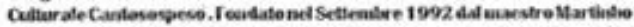
Latere, sas attade direttore, si dedica prioeitariamente alla muskica africans e tatine auericana , sema trascurare tatie le altire culture ded

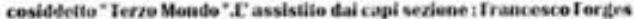
Diaglo Aletoni e dalla maestra fictt fast.

\section{SMURA}

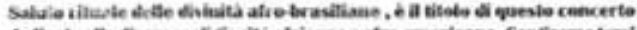

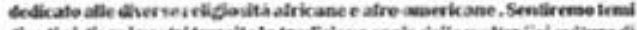

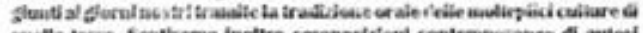

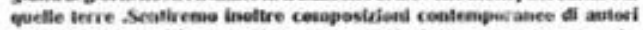

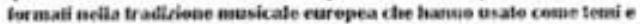

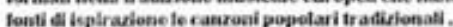

Bicto de

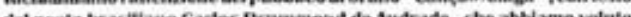

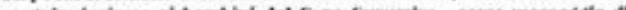

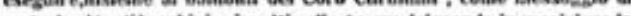
ang

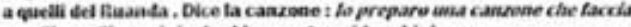

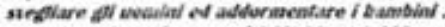

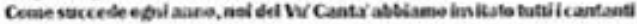

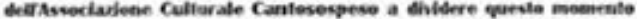

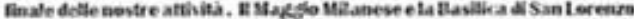

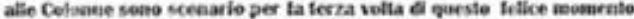

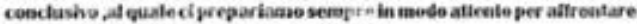
le sue particutal caratieristictie actsslict . .

Beonascotio:
MAGGIO MILANESE '94

COE-CENIRO ORIENIAMENTO EDUCATIVO

PRESENIA

\section{$\underline{S} \mathbf{A}<\cup B A$}

CONCERTO DEI CORO VU CANTA' direttore - MARTINio LUERo

SAвATO 28 MAGGiO 1994 ORE 21

BASUUCA DI SAN LORENZO AUE COLONNE

Corso di Porta Iicinese - MLLNo

INGRESSO UBERO

\section{$\begin{array}{lllllllll}\text { P } & \text { R } & \mathbf{O} & \mathbf{G} & \text { I } & \text { A } & \text { M } & M & \text { A }\end{array}$}

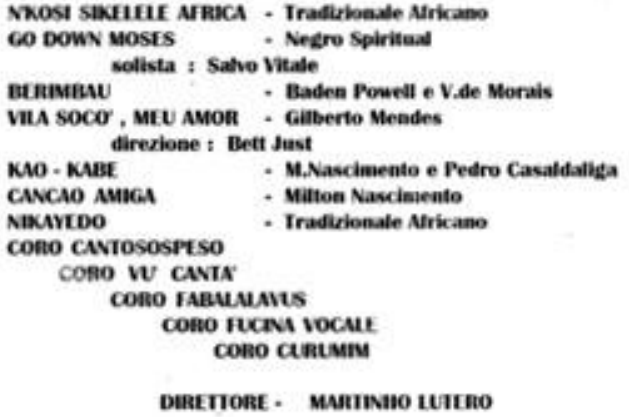

Chitarra

Nov mantano

Percassioni

Kul bos swios

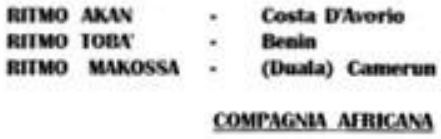

fadonotgBo Kott Michel - Eotsun Pierre-Marie sorro Dombe Ferdinand - SAvGA Mimbang Danietle faDoNougno A, Jonas - MruzoU Nidjamen Bertin ronges Irancesce

$$
\text { 000-000 }
$$

Brani rcetil datla Missa LuA - Conko

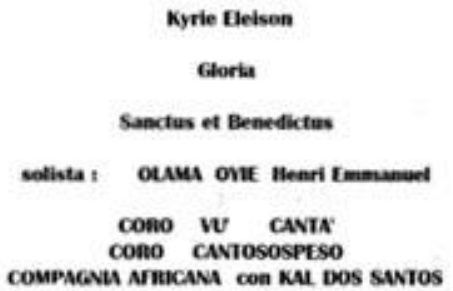

paturtonf - Murtivito urtho 


\section{ANEXO C}

Curso de férias em parceria com a escola de música II Classico

\section{Il Classico}

Scuola di Musica

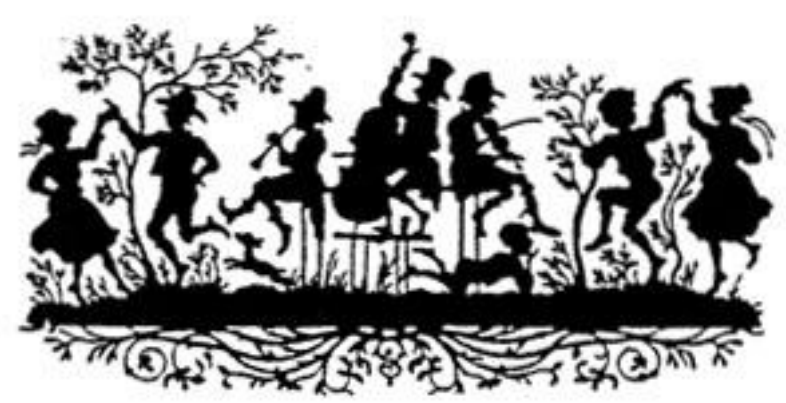

Dal 12 al 24 Giugno si terrà un

Corso Intensivo per la formazione di un

\section{Coro di Voci Bianche}

per Gambini da 5 a 10 anni, a cura dei Maestri

\section{Martinfo Lutero}

e

Bett Just

Verrì proposto un repertorio di canti tratto della tradizione classica $e$ popolare di tutto il mondo, in varie fingue.

Durante if Corso verranno trattati argomenti qualt la tecnica di respirazione e di impostazione della voce e saranno formiti elementi di base per la lettura cantata della scrittura musicale

Per infomazioni ed iscrizioni nivolgersi a :

If Classico

Tha Montegani, 1 - Via Bamifi, 24

TeL. 89.53.10.37 


\title{
ANEXO D
}

Calendário de ensaios e da apresentação do espetáculo Tele e Visione

\section{Il Classico}

\author{
Scuola dî Musica
}

\section{Calendario per il mese di Maggio}

per $i$ partecipanti al coro, non iscritti ai corsi di strumento

\author{
Quest anno if coro ì stato inserito nello spettacolo cfie "Il Classico" organizza a fine anno, \\ esattamente if 26 maggio alle ore 16,30 . \\ Per poter pemettere fa reafizzazione di tafe spettacolo le uftime lezioni del con si \\ soolgeranno in una sala presso if teatro, come descritto dal seguente calendario, \\ in modo da poter essere ad un tempo sia lezioni che prove di insieme con gla aftri affievi. \\ Le fezioni del coro si concluderanno quindi con lo spettacolo.
}

\section{Sa6ato 25 Maggio}

La lezione di coro si temà nel teatro "Sala Onizzonte" di piazza Damiano Cfriesa dalle 16,30 afle 18,00 circa, per pennettere anche tna prova con tuttigfi aftri aflevi.

\section{Domenica 26 Maggio}

In teatro prova generale della musica per if coro alle 14,30

prova Generale per tutti alle 15,00

Vestizione ed uftimi preparativi alle ore 16,00

\section{Lo spettacolo: \\ "Tele e Visioni" \\ inizierà alle 16,30}




\section{ANEXO E}

Capa do programa de sala do espetáculo Girotondo

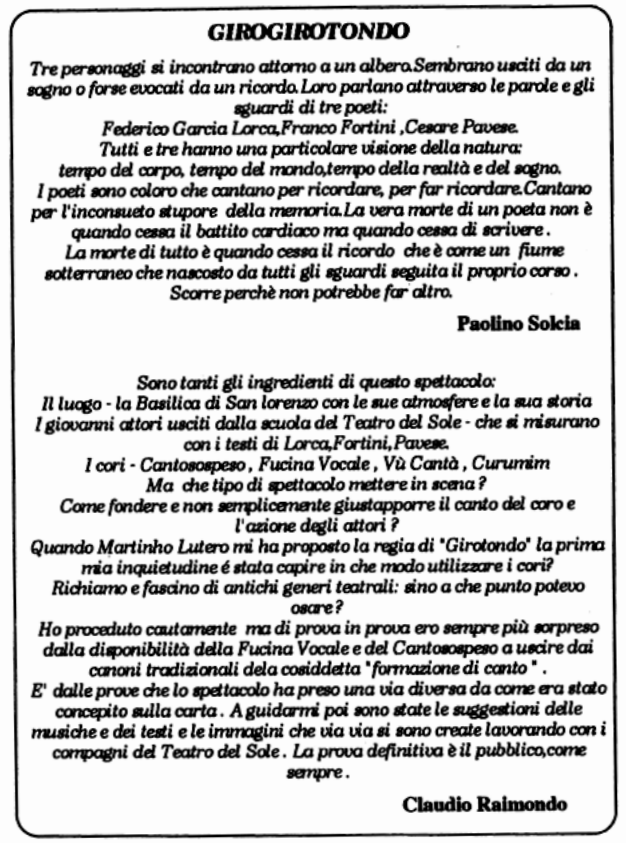

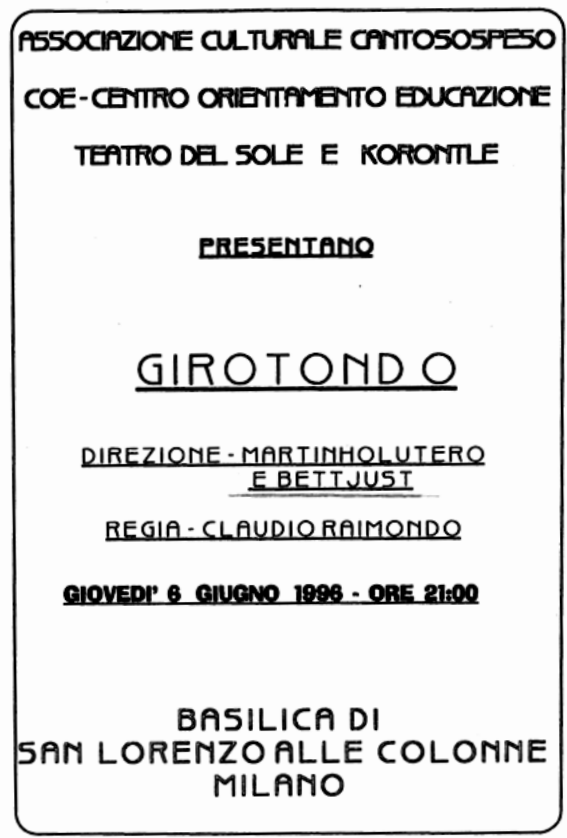

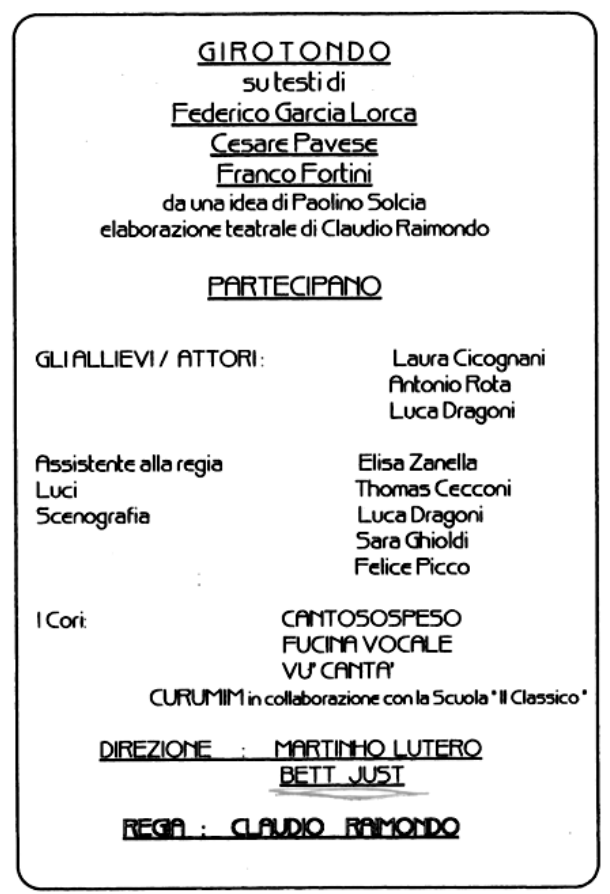

\section{ELEMCO DEL BRRAM MUSICALI ESEGUITI DAI CORI \\ MADRIGAL Edino Krieger}

CIO DA TERRA Milton Mascimento $e$ Chico Buarque

TUROT ESZIK A CIGArMY Zoltan Kodály

AMOITECEU Assis Valente

SILANOCHEHACEESCURA Cancionero de Upsala

WALDESTACHT Johames Bratms

LOSCUATROMULEROS Federico Garcia Lorca

LAS TRESHOUAS F. GarciaLorca

MAMADESEVILLA F. GarciaLorca

LOSMOZOSDEMONLEOMF. GarciaLorca

IL TRENO-SHAPOPO tradizionale giapponese

A LEMDADO ABAETE' Dorival Caymi

VILASOCO' Gilberto Mendes

MKOSI SIKELELIAFRICA Tradizionale Africano 


\section{ANEXO F}

Ensaios extras para os espetáculos Tele e Visione e Girotondo

$$
\begin{gathered}
\text { Calendario delle prove } \\
\text { del } \\
\text { CORO CURUMIM } \\
\frac{\text { *Tele e Visione" }}{25 \text { maggio, dalle } 16: 30 \text { alle } 18:}
\end{gathered}
$$
Prova.

26 maggio, alle 14:30 : Prova generale.

alle $16: 30$ : Inizio.

Piazza Damiano Chiesa, "Sala

Orizzonte".

"Giro, girotondo"

05 giugno, alle 20;00 : Prova generale.

07 giugno, alle 21:00 : Concerto. Basilica di San Lorenzo alle colonne.

*Gli alievi di strumenti della scuola avranno altri orari per "Tele e Visione". 


\section{ANEXO G}

Publicidade do Coro Curumim em parceria com a Società Umanitaria

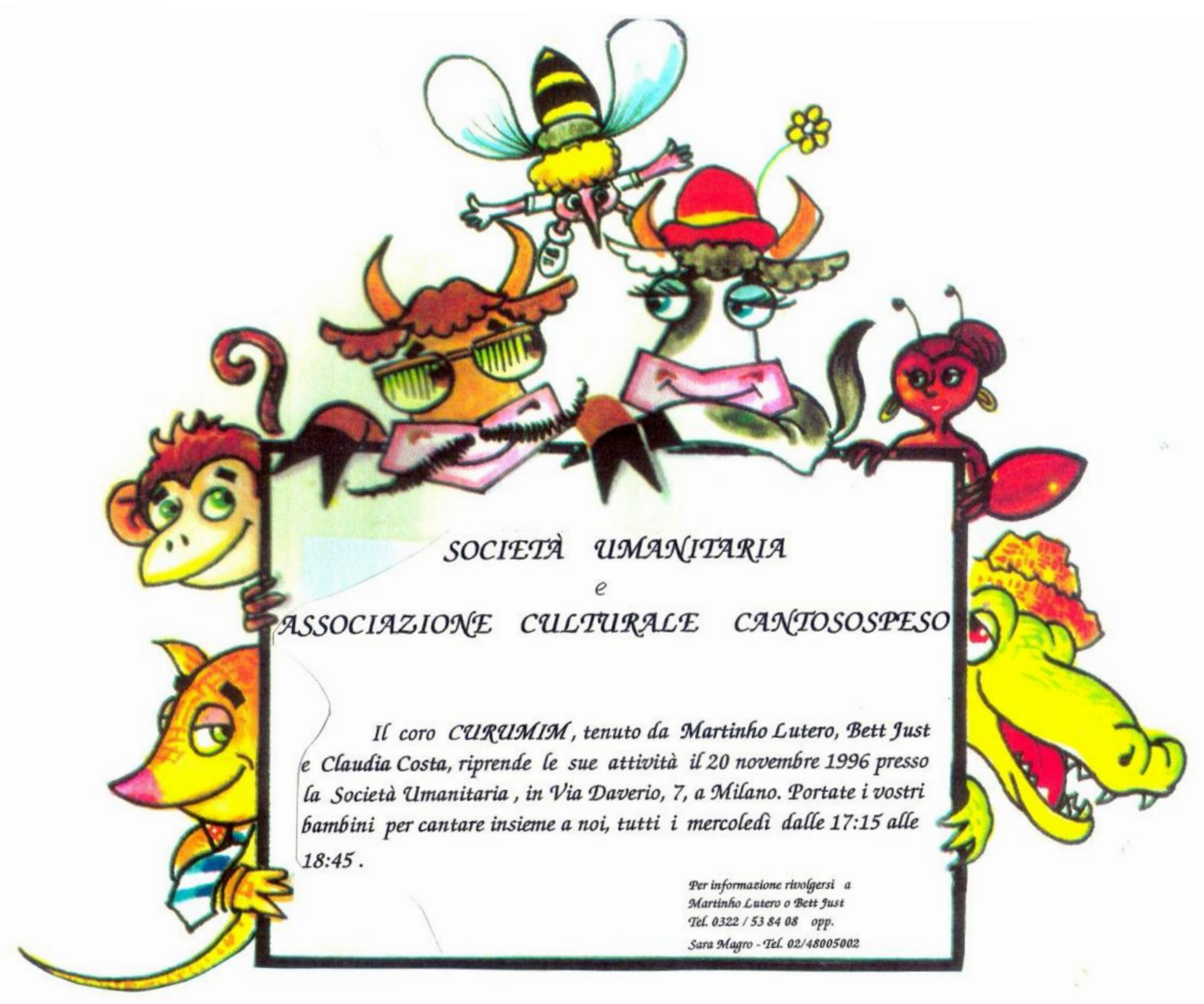




\section{ANEXO H}

Primeira chamada do Coro Curumim em 1996 no TG CORO
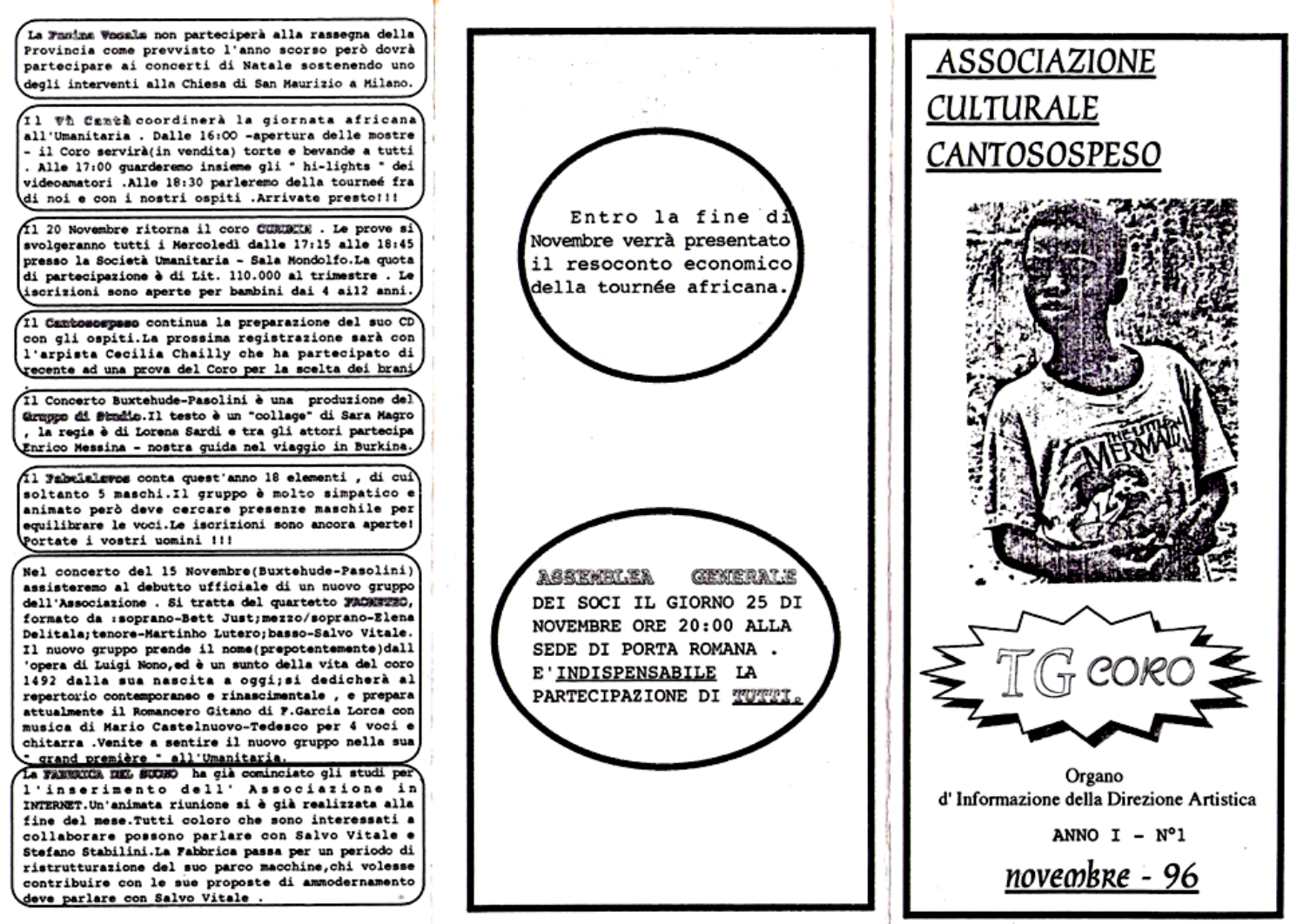

videoamatori Alle 18:30 parleremo della tóurneé fra di noi e con $i$ nostri ospiti .Arrivate presto!!!

Il 20 Novembre ritorna il coro CCRRBR . Le prove si svolgeranno tutti i Mercoledì dalle 17:15 alle 18:45 presso la Società Umanitaria - Sala Mondolfo. La quota di partecipazione è di Iit. 110.000 al trimestre. Ie iscrizioni sono aperte per bambini dai 4 ail2 anni.

Il Caverosospeso continua la preparazione del suo CD nam rii noniti T.s nuncaims ronietraninno earà non 


\section{ANEXO I}

Resumo das atividades do Coro Curumim em parceria com a Società Umanitaria

\begin{tabular}{|c|c|c|c|c|c|}
\hline \multicolumn{6}{|c|}{ ATTIVITÀ CONGIUNTA UMANITARIA / CANTOSOSPESO } \\
\hline \multicolumn{6}{|c|}{ CURUMIM - $1997-2002$} \\
\hline & $1997 \cdot 1998$ & $1998-1999$ & $1999-2000$ & $2000-2001$ & $2001 \cdot 2002$ \\
\hline $\begin{array}{l}\text { Equipe di } \\
\text { lavoro }\end{array}$ & $\begin{array}{l}\text { I dir. artisitico } \\
2 \text { insegnanti } \\
1 \text { assistente }\end{array}$ & $\begin{array}{l}1 \text { dir. artisitico } \\
\text { I insegnante } \\
\text { I assistente }\end{array}$ & $\begin{array}{l}1 \text { dir. artisitico } \\
1 \text { insegnante } \\
\text { I assistente }\end{array}$ & $\begin{array}{l}1 \text { dir. artisitico } \\
1 \text { insegnante } \\
2 \text { assistenti }\end{array}$ & $\begin{array}{l}1 \text { dir. artisitico } \\
\text { I insegnante } \\
1 \text { assistent } i\end{array}$ \\
\hline $\begin{array}{l}\text { Spesi con } \\
\text { operatori }\end{array}$ & $\begin{array}{l}2 \text { Insegnanti }= \\
\text { f55.000 (ciascuno)ora } \\
\text { netto } \\
\text { f Assistente }= \\
\text { f25.000 ora netto } \\
+-1.200,00\end{array}$ & $\begin{array}{l}1 \text { insegante }= \\
\text { f } 55.000 \text { ora netto } \\
1 \text { Assistente }= \\
\text { \& } 25.000 \text { ora netto } \\
+-14.800,00\end{array}$ & $\begin{array}{l}\text { I insegnante }= \\
\text { f 75.000 ora L. } \\
1 \text { Assistente }= \\
\text { \& } 40.000 \text { ora L } \\
+\neq 11.500,00\end{array}$ & $\begin{array}{l}1 \text { insegnante } z \\
\text { f } 75.000 \text { ora } L \\
2 \text { Assistenti } \\
\text { f } 40.000 \text { ora } L \\
+\neq 10.000,00\end{array}$ & $\begin{array}{l}1 \text { insegnante }= \\
\text { f } 75.000 \text { ora } L . \\
1 \text { assistente } \\
\text { f63.07380 ora L. } \\
+-8.600,00\end{array}$ \\
\hline GRUPPI & $\begin{array}{l}2 \text { gruppi: } \\
\text { martedi (1 ora) } \\
\text { giovedi (1 ora) }\end{array}$ & $\begin{array}{l}2 \text { gruppi: } \\
\text { martedi( } 1: \text { ora) } \\
\text { giovedi (1:15) }\end{array}$ & $\begin{array}{l}\text { 3 gruppi: } \\
\text { martedii (1 ora) } \\
\text { mercoledit(1ora) } \\
\text { giovedi (1:15) }\end{array}$ & $\begin{array}{l}\text { 3 gruppi: } \\
\text { martedi( } 1 \text { ora) } \\
\text { mercoledi( } 1 \text { ora) } \\
\text { giovedi (1:15) }\end{array}$ & $\begin{array}{l}2 \text { gruppi: } \\
\text { martedi( ora) } \\
\text { giovedi (1:30) }\end{array}$ \\
\hline $\begin{array}{l}\text { Numero di } \\
\text { Bambini }\end{array}$ & 34 & 41 & 47 & 40 & 20 \\
\hline $\begin{array}{l}\text { ATTIVITà } \\
\text { EXTRA }\end{array}$ & $\begin{array}{l}\text { Saggio di fine anno } 30 \\
\text { maggio. } 98 \text { insieme ai } \\
\text { gruppo di propedeutica } \\
\text { ait Antonio Testa } \\
\text { pubblico:genitori }\end{array}$ & 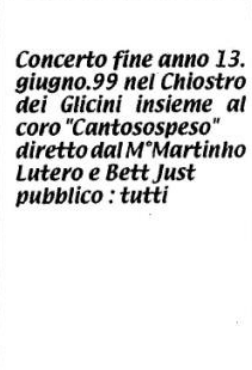 & 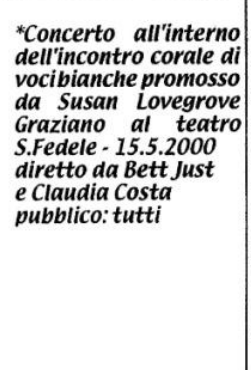 & 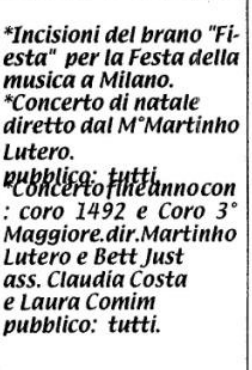 & \\
\hline
\end{tabular}

\begin{tabular}{|c|c|c|c|c|c|}
\hline Repertorio & $\begin{array}{l}\text { N'Kosi sikeleli } \\
\text { La gata y el belitre } \\
\text { Venite compagni } \\
\text { Palomita Blanca } \\
\text { Os brinquedos } \\
\text { La lune est mort } \\
\text { Dorme a cidade } \\
\text { Milho Verde }\end{array}$ & \begin{tabular}{|l|} 
N'Kosi sikeleli \\
Palomita Blanca \\
Dorme a cidade \\
"Il treno \\
*Mwana Kondo \\
*era nato poveretto \\
*Borboleta \\
"La orchestra \\
"Anin a nolis \\
"Canto Txucarramae
\end{tabular} & $\begin{array}{l}\text { N'Kosi sikeleli } \\
\text { Palomita Blanca } \\
\text { Dorme a cidade } \\
\text { Il treno } \\
\text { Era nato poveretto } \\
\text { Mwana Kondo } \\
\text { Anin a nolis } \\
\text { Os brinquedos } \\
\text { La orchestra } \\
\text { "Tche Nane } \\
\text { "Duetto buffo di } \\
\text { due gatti" } \\
\text { duckoo! } \\
\text { "Cuckigao amiga } \\
\text { "Cançaaiedo } \\
\text { "Nikaiedo } \\
\text { "Pirulito que bate- } \\
\text { bate }\end{array}$ & \begin{tabular}{|l|} 
N'Kosi sikeleli \\
Palomita Blanca \\
Dorme a cidade \\
Il treno \\
Era nato poveretto \\
Mwana Kondo \\
Anin a nolis \\
La orchestra \\
Nikaiedo \\
Dueto buffo \\
Cuckoo \\
*Asa Branca \\
*ceremony of Car- \\
ols \\
"Adeste Fidelis \\
"Younder come day \\
*Festa! \\
*Das Klinget \\
\end{tabular} & $\begin{array}{l}\text { N'Kosi sikeleli } \\
\text { Palomita Blanca } \\
\text { Dorme a cidade } \\
\text { Era nato poveretto } \\
\text { Anin a nolis } \\
\text { Dueto buffo } \\
\text { Cuckoo } \\
\text { Younder come day } \\
\text { Borboleta } \\
\text { Milho verde } \\
\text { Cançao amiga } \\
\text { Das Klinget } \\
\text { *A Aa orilla } \\
\text { *Venite, venite } \\
\text { *Corre Cotia } \\
\text { *Su, su, su! } \\
\text { *Sapo Cururu } \\
\text { *Alla fiera di } \\
\text { Mastro Andre } \\
\text { Ka lune est mète }\end{array}$ \\
\hline
\end{tabular}




\section{ANEXO J}

Coro Curumim do ano letivo1997/1998

Fotografia tirada no espetáculo I/ negozio dei giocattoli (A loja dos brinquedos), idealizado por Antonio Testa.

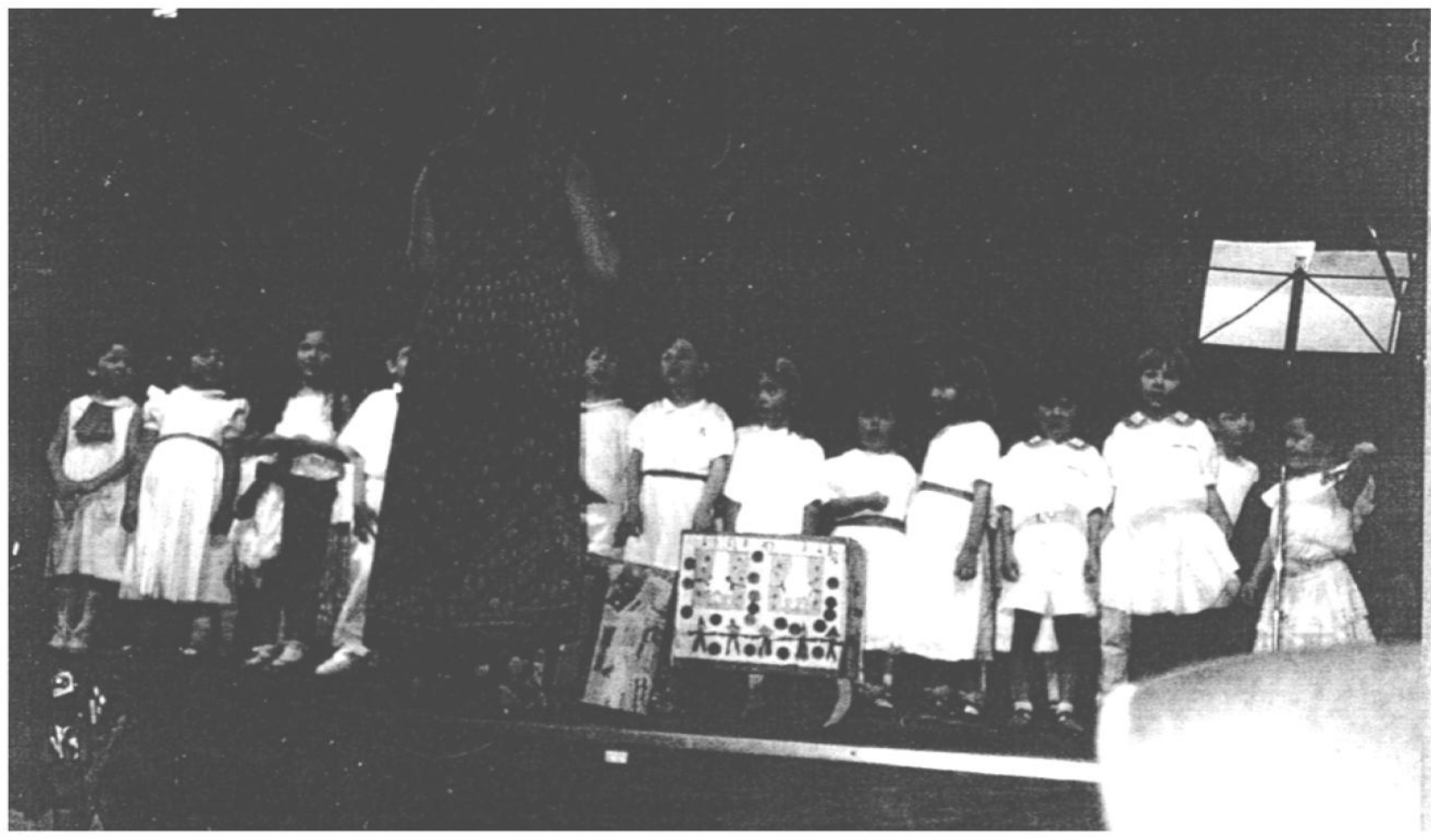




\section{ANEXO K}

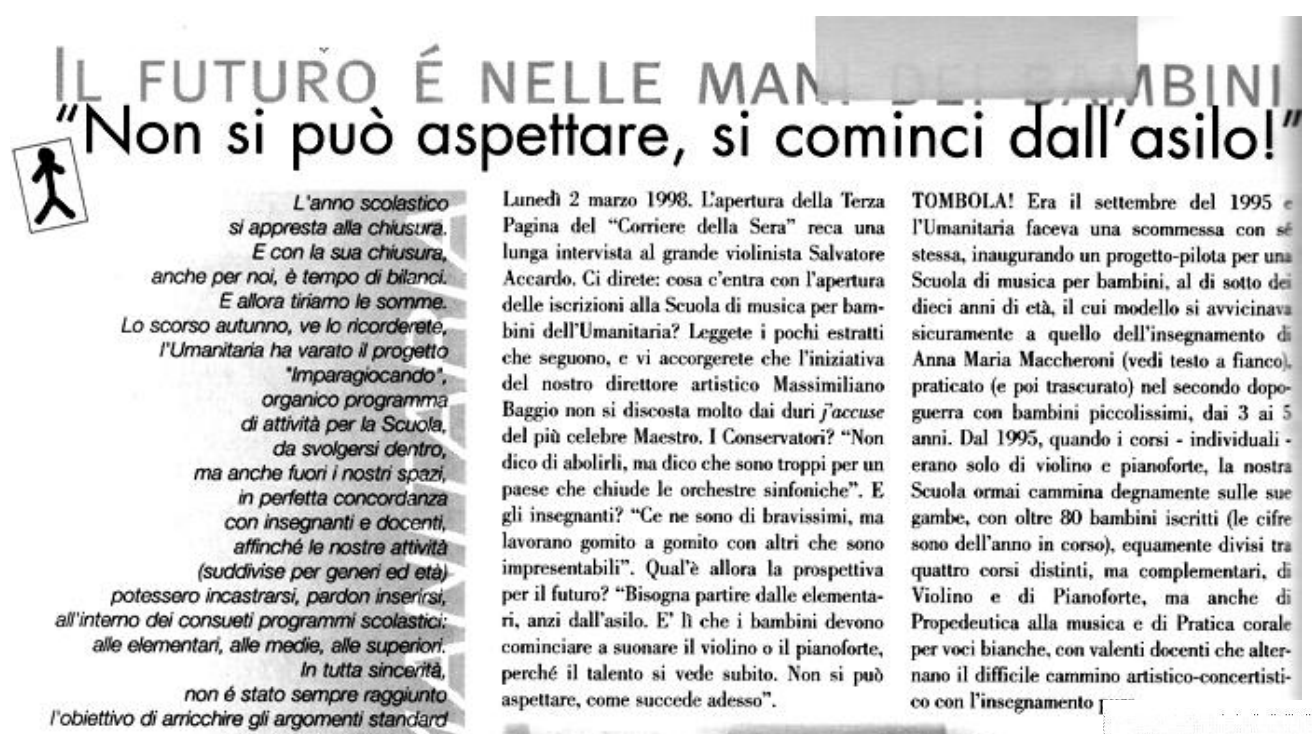

robiettivo di arrich es stato sempre raggiunto

ma sono state comsegnament,

le premesse necessarie

per continuare un indinzzo socio-educativo

che ha dato buoni risultati.

Ma entriamo nello specifico,

senza farci influenzare da statistiche,

tabelle e proiezioni di preferenza

sui pro e contro che tanto vanno di mada

(nan solo durante le campagne elettorali).

Un anno dopo, non ci siamo abbattuti

per la quantità di adesioni ricevute,

ma siamo intenzionati a procedere,

pur con qualche miglioria strutturale,

e qualche limatura di contenuto.

Vi possiamo confermare che ci saranno

le animazioni musicali e quelle sul cabaret; tomeranno gif spettacail di

'Teatro, infanzia, solidarieta'

e le lezioni-concerti mattutine, dove i giovani musicisti

hanno saputo raccontare al foro pubblico

tante curiosità su musiche,

strumenti, compositori;

proseguira il ciclo of

"Cinema e Storia",

con $i$ suoi film tra storia, cronaca, società.

Infine, ci sarà la mostra di fumetti e satira.

contro l'inquinamento.

che quest'anno ha avuto

un circuito extra-scolastico.

ospite presso associazioni e biblioteche.

Che dire di più? Nelle prossime pagine

troverete un sintetico prospetto delle nostre attivitat qualche pagina di stoná det nostro ente, e alcuni tem sul corso di "Cinema e Storia".

In attesa di ricevere le vostre adesioni. restiamo a vostra disposizione.

augurandoci che, di comune accordo. la maturazione del giovan divenga un cammino graduale capace di insegnare fin dai primi anni scolastici.

il significato della dialettica tra diritti e doveni, dell' eguaglianza, del rispetto dell altro.

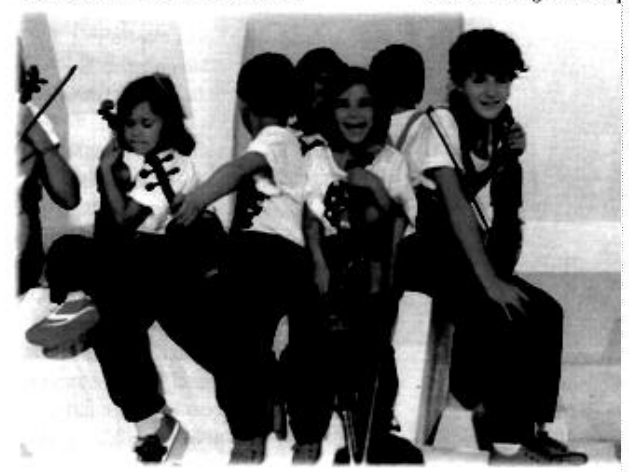

Corso di violino e pianoforte

Il violino e il pianoforte sono gli strumenti riconosciuti come i più idonei per un precoce avvio alla musica. Entrambi $\mathrm{i}$ corsi prevedono una attenta selezione degli aspiranti che dowranno seguire un perconso didattic pari a quello dei tradizional Conservatori.

Metodologia

Le lezioni, individuali, sono un'ora alla settimana per un totale di 32 incontri.

Accesso

Lammissione è prevista previa

selezione. Sono ammessi i ban.

bini che hanno gia frequentato $i$

corsi di propedeutica e di prati- Il corso è rivolto a hambini dai

ca corale o quelli che sappiano 4 agli 11 anni

Corso di pratica corale

per voci bianche

Il canto corale è la forma imme-

diata di introduzione alla pratica musicale Partecipandoni, i Lambini potanmo avicine alla lettura degli spartiti, al saper dis mondo dell'intonazione e dell'a- stiche qu scolto musicale in maniera gio- il silenzi

Metodologia

Le lezioni, della durata di un'o- Metodo ra ciascuna, sono rivolte a grup. Le lezion pi formati da un minimo di 15 ra ciasce ad un massimo di 30 allievi per pi forma

un totale

un torale

Accessi

Il corso it 4 agli 11

$\begin{array}{lll}\text { Docenti } & \text { Docenti } & \text { Docenti } \\ \text { Alessandra Farro (vl), Carlo } & \text { Martinho Lutero, Bett Just, Antonio }\end{array}$ Palese (p), Alessandro Pilar Bravo Martinez, Claudia Alvear, Commellato ( $\mathrm{p}$ ). $\quad$ Regina Costa, Emesto Ferrini. Pablo Pa

\section{Corso di pratica corale per voci bianche}

Il canto corale è la forma immediata di introduzione alla pratica musicale. Partecipandovi, i bambini potranno avvicinarsi alla lettura degli spartiti, al mondo dell'intonazione e dell'ascolto musicale in maniera giocosa.

\section{Metodologia}

Le lezioni, della durata di un'ora ciascuna, sono rivolte a gruppi formati da un minimo di 15 ad un massimo di 30 allievi per un totale di 32 incontri.

\section{Accesso}

Il corso è rivolto a bambini dai 4 agli 11 anni

\section{Docenti}

Martinho Lutero, Bett Just, Pilar Bravo Martinez, Claudia Regina Costa, Emesto Ferrini. 


\section{ANEXO L}

\section{Publicidade e parte do roteiro da peça II Negozio dei Giocattoli}

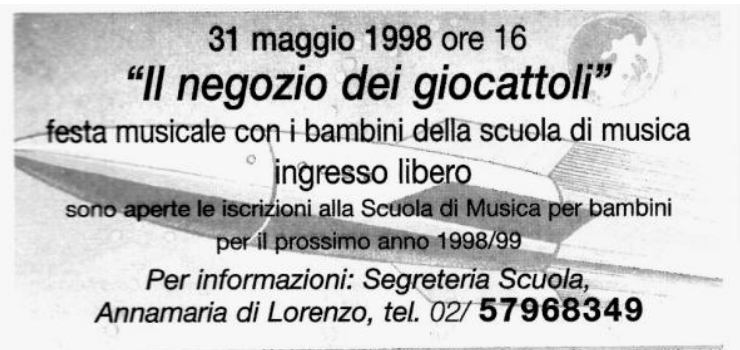

\section{Il negozio dei giocattoli}

NARRATORE : Era un bellissimo giomo di primavera e, $\underset{\rightarrow \text { Pomba branca }}{\text { portoghese - italiano-portoghese }}$ nonostante il sole brillasse e gli uccellini cantassero, un bimbo camminava solo per la città.

La città era troppo rumorosa ed impegnata per giocare con lui, ma ad un certo punto la sua attenzione fu attirata da una luce lontana in fondo ad un vicolo.

Seguendo la strada arrivò davanti ad una bellissima vetrina dove si vedevano due allegri vecchietti in mezzo ad un sacco di giocattoli : cosi tanti e cosi bei giochi tutti insieme non li aveva mai visti.

$\rightarrow \frac{\text { Os brinquedos - ibambini sialsano }}{\text { per prendere i gioccatbli - }}$

Decise di entrare nel negozio per vederli da vicino : gialli, rossi, verdi, di legno, di metallo, elettrici, ce n'erano di tutti i colori.

Girando tra i vari giocattoli non si accorse neppure del passare del tempo e ormai stanco si addormentò.

Al calar della sera. i due vecchietti chiusero il negozio e si avviarono ientamente verso casa. (GROSSA PAUSA).

Dorme a cidade - dove sent

Allo scoccare della mezzanotte-i-rintocchi--dell'orologio svegliarono il bambino che, come per magia, vide $i$ giocattoli rianimarsi. 


\section{ANEXO M}

Apresentação de conclusão do ano letivo 1998/1999

\section{Scuola di Musica per Bamb ni}

Domenica 13 giugno 1999

ore $\mathbf{1 8 . 0 0}$

\section{Saggio del Corso di Partica Corale}

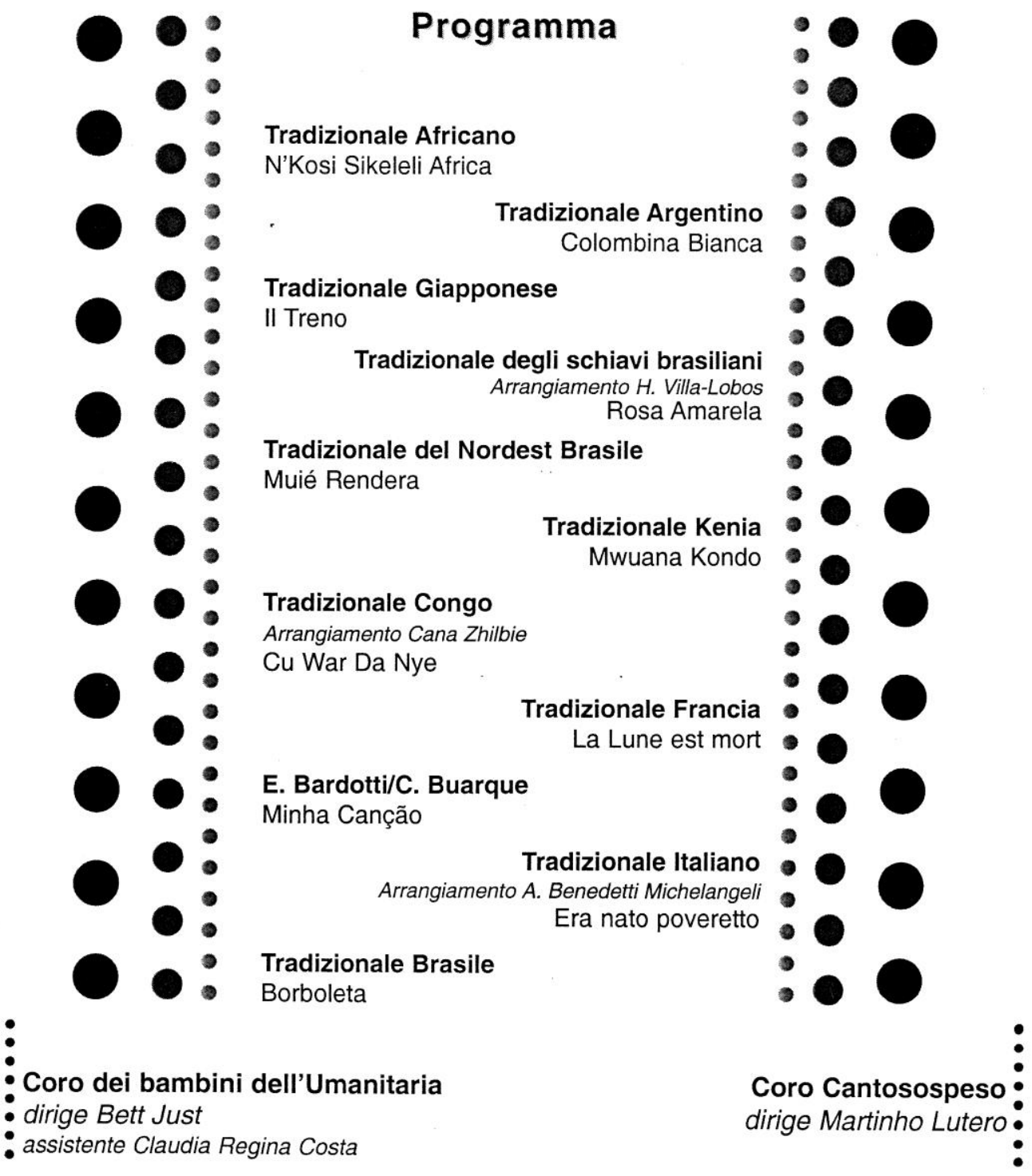




\section{ANEXO N}

Nomes das crianças do Coro Curumim no ano letivo 1998/1999

Pierluigi Aconito

Luca Albani

Giuliano Baggio

Alessandro Baggio

Aurora Bani

Alessandro Bazzoli

Giulia Bernardi

coro

Carlotta Broglio

Dejandra Caramelli

Giacomo Cattoretti

Luis Chimina

Michael Chimina

Marta Colaneri

Sofia Finzi

Agnese Ghidoli

Chiara Ghidoli

dei bambini

Marco Giacobbe

Cecilia Giubileo

Carolina Jorio

Virgilio Lutero

Giacomo Macrì

Q6)

Laura Montanaro

Lorenzo Pellegrini

Pietro Pettenghi

Danae Rikos

Vittoria Ripa di Meana

Michel Rossini

Mattia Trabucco

Ludovico Vacchelli

Silvia Yang

Virginia Zucchelli
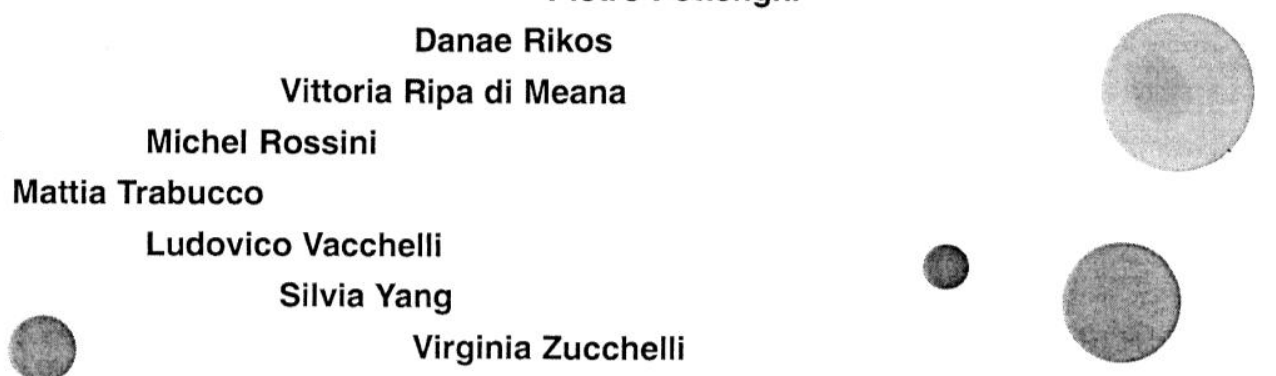


\title{
ANEXO O
}

Concerto Mille Voci per la Pace

ASSOCIAZIONE CULTURALE CANTOSOSPESO

\section{MANIFESTAZIONE GORARE}

\section{MILLE VOCI PER LA PACE CONCERTO CORALE AL DUOMO DI MILANO}

Dieci brani sacri interpretati dai singoli cori e il Pater Noster di I. Stravinski eseguito da tutti i cori insieme

\section{SABATO 12 GIUGNO 1999 ORE 19}

\author{
preceduto da una \\ Passeggiata corale
}

\author{
Partenze alle ore $18 \mathrm{da}$ : \\ Piazza della Scala - 6 cori \\ Largo Cairoli - 8 cori \\ Piazza Diaz - 5 cori \\ Piazza San Babila - 8 cori
}

\begin{abstract}
Aderiscono:
Coro Polifonico dell'Acqua Potabile, Coro Didone, Coro Rondinella, Coro Cai - Cinisello B., Coro della scuola di via Cesare, Coro Città di Milano, Coro Hispano Americano, Coro Musirè, Coro Orlando di Lasso, I Maestri Cantori, Coro di San Marco, Corale Polifonica di Cassina dè Pecchi, Coro Col Hakolot, Coro dell'Accademia di Musica H. Villa - Lobos, Coro La Vetta, Coro Città di Vimercate, Coro Bandeko, Coro di Lissone, Coro Treccine, Coro Stella Alpina, Coro Alpino Lombardo, I Cantori di Rinascita, Coro Popolare Miceni, Coro Voci dei Navigli, Coro II Rifugio, Coro dei Bambini della Scuola di Musica della Società Umanitaria
\end{abstract}

Info: tel. 0322/50004 - 0335/6007082

lutero@intercom.it - www.freeweb.org/musica/cantosospeso 


\title{
ANEXO P
}

Programa de sala do Happening Corale con le Scuole

\author{
OGGI SI CANTAI! HAPPENING CORALE CON LE SCUOLE \\ 13 Maggio, 2000 - Auditorium San Fedele
}

Cori partecipanti:

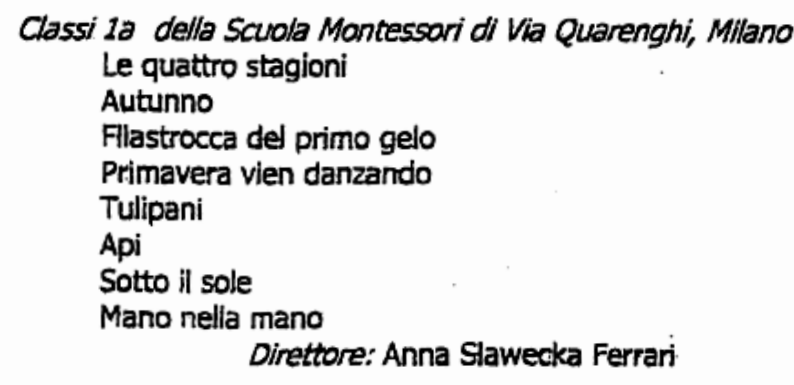

Coro di voci bianche della Scuola Civica di Musica della Provincia di Sandrio Do, dove vai? Composizione originale del coro

Bella ciaol, a tre voci

Ciu ciu

Ev'ry time I feel the spirit

Canto popolare argentino

$$
\text { a } 3 \text { voci }
$$

Rock-a my soul, a tre voci. Spiritual

Direttore: Cecilia Turchi

II Milano Vocal Ensemble, quartetto vocale

Dog dog

I woke up this morning

Embraceable you

Soon and very soon
Canto tradizonale africana

Spiritual

George Gershwin (1898-1937)

Spiritual

Cantanti: Ludovica Cotta-Ramusino, soprano; Daniela Tondini, contralto; Gluseppe Presti, tenore; Paolo Graziano, basso

\section{Intervallo}

Coro ospite: CORO CURUMIM di voci bianche della Società Umanitaria e I'Associazione Culturale Cantosospeso

Tche Nane

Era nato poveretto

Colombina bianca

Il treno

Duetto buffo di due gatti

N'kosi sikeleli Africa

Direttore. Bett Just

Presentazione: Maurizio Granato

Direzione artistica: Susan Lovegrove Graziano 


\section{ANEXO Q}

Certificado de participação ao Happening Corale con le scuole

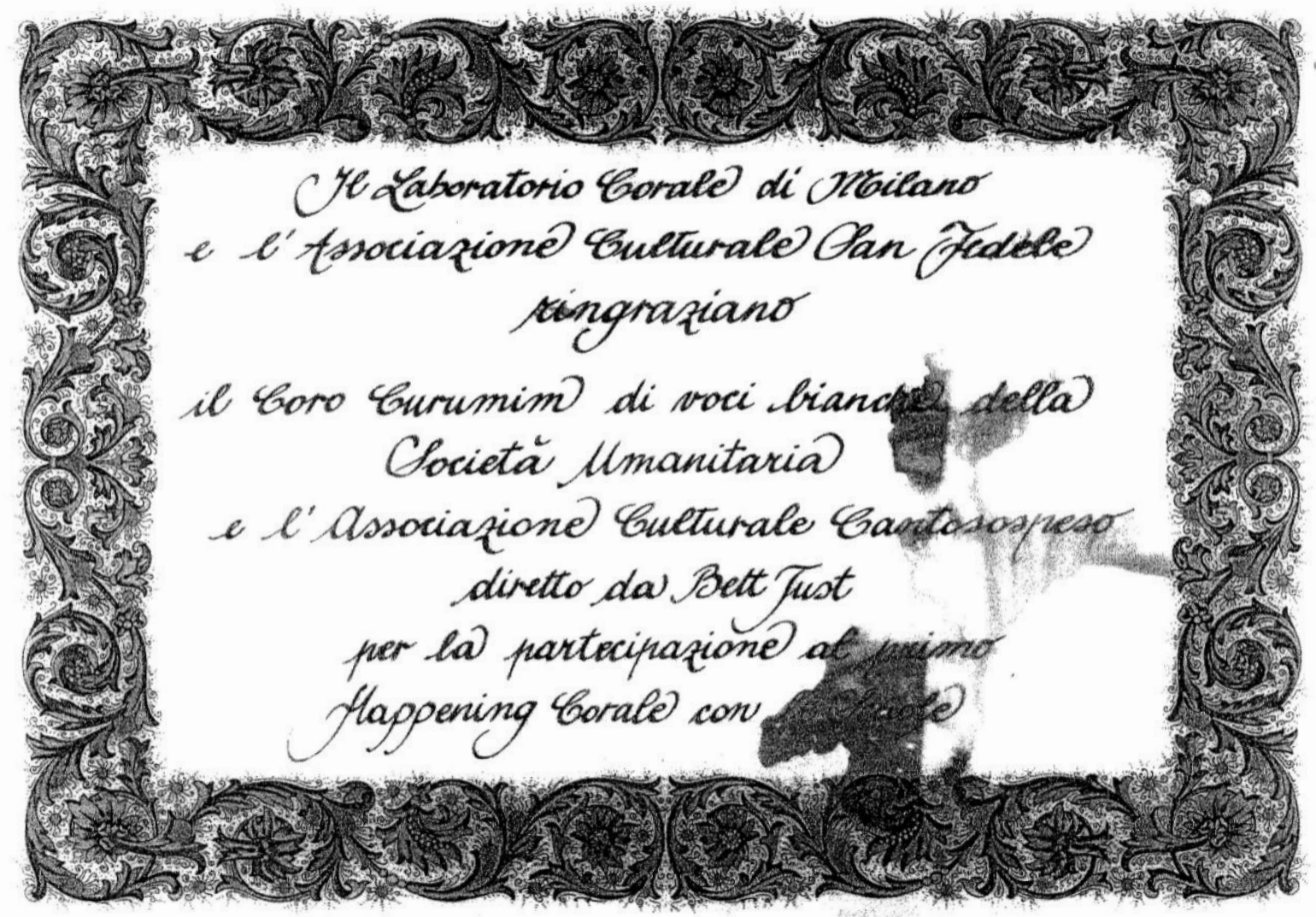

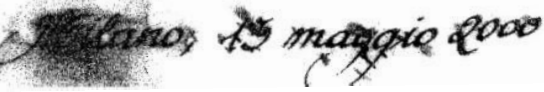




\section{ANEXO R}

Apresentação de conclusão do ano letivo 1999/2000

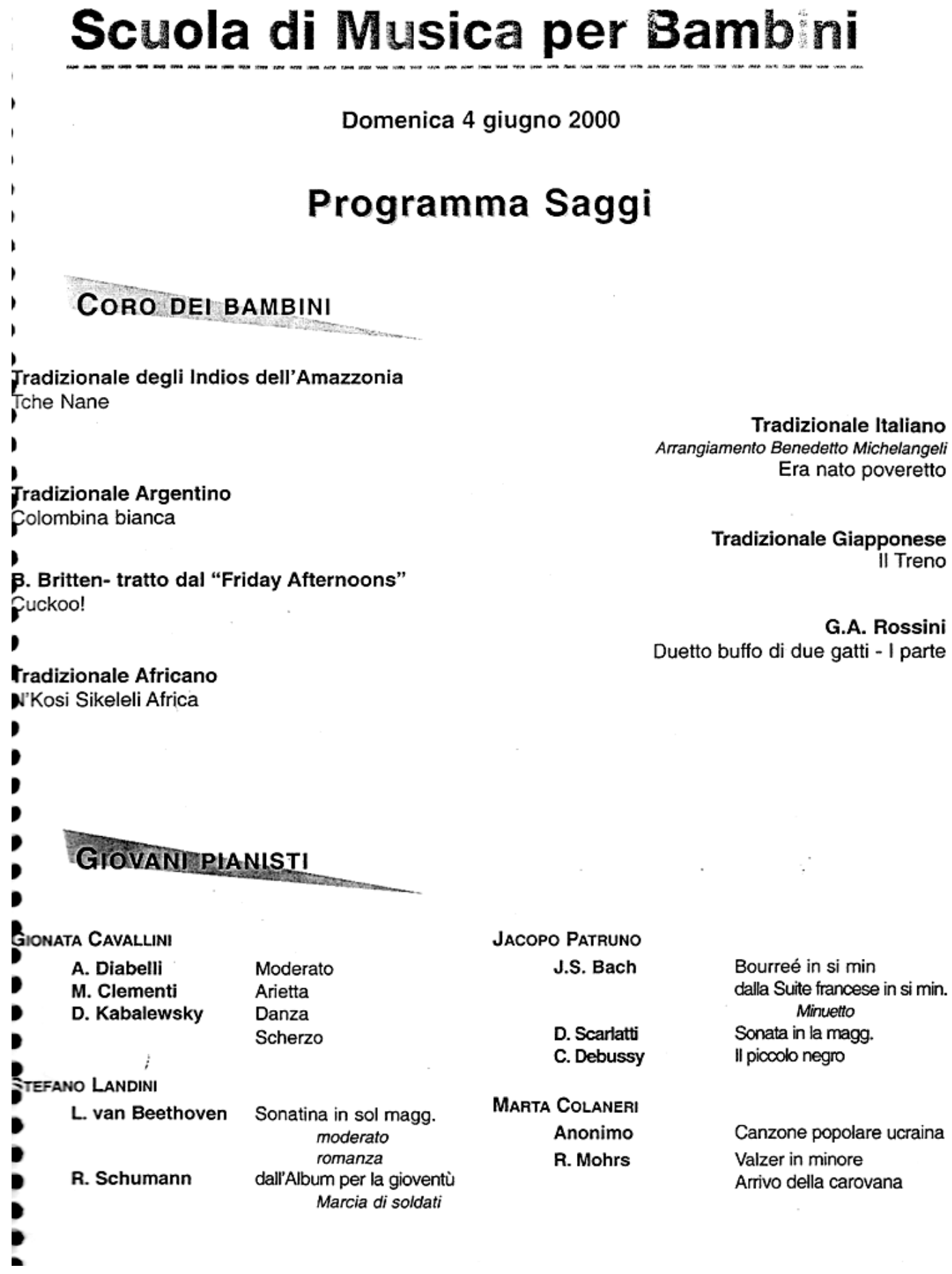




\section{ANEXO S}

CD FESTA! e autorização de uma criança, Carlotta Broglio, para participar da gravação

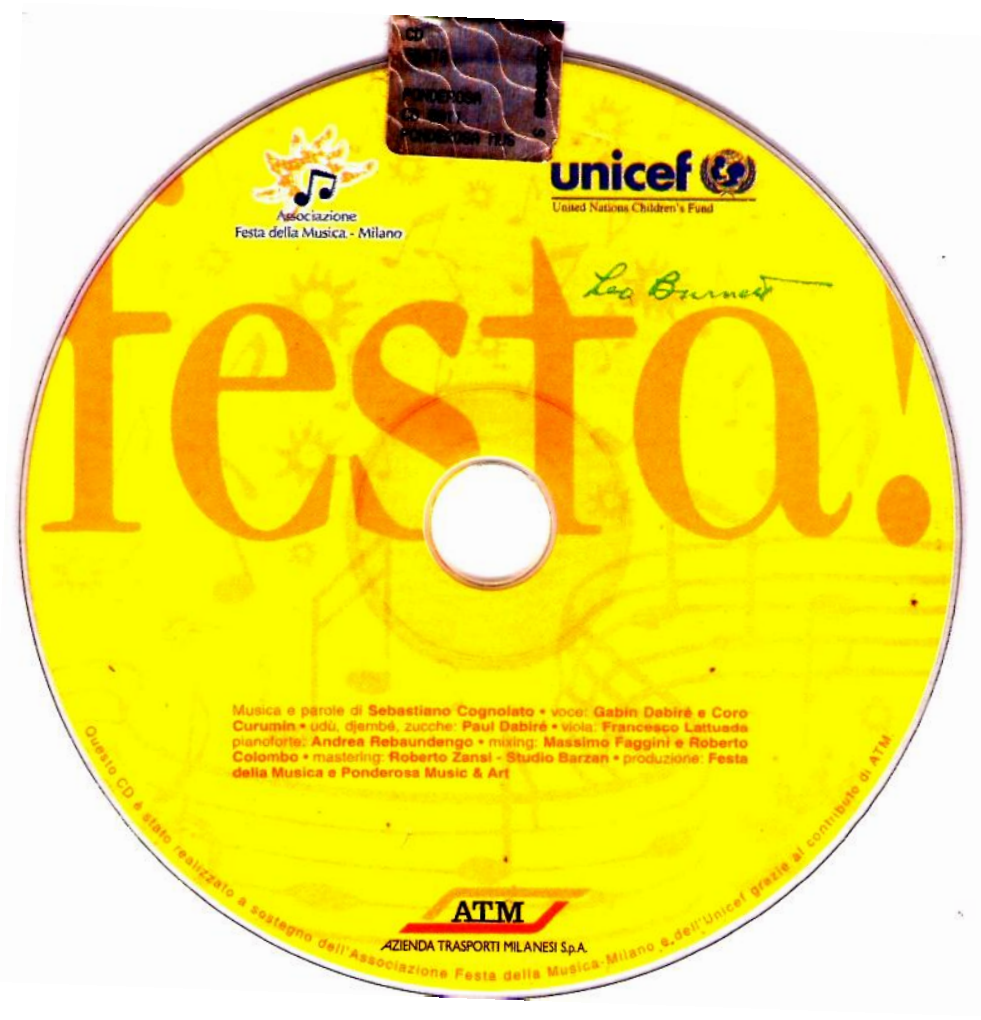

AUTORIZZAZIONE

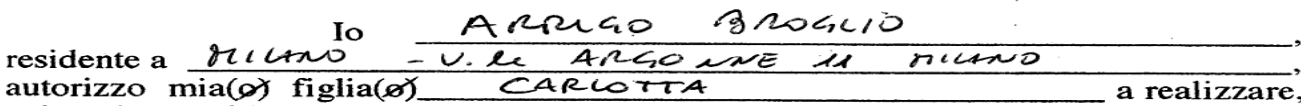

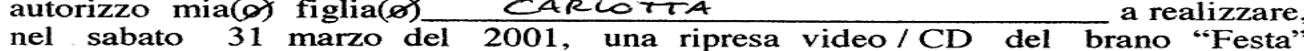
di Sebastiano Cognalato per la Festa della Musica a Milano.

Il materiale registrato non verrà utilizzato a fine di lucro, conforme attesta la lettera allegata.

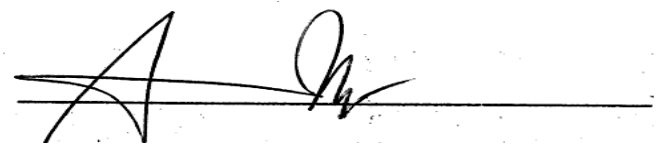




\section{ANEXO T}

Publicidade do Coro Curumim em Via Sforza, Milão, na Libreria Claudiana

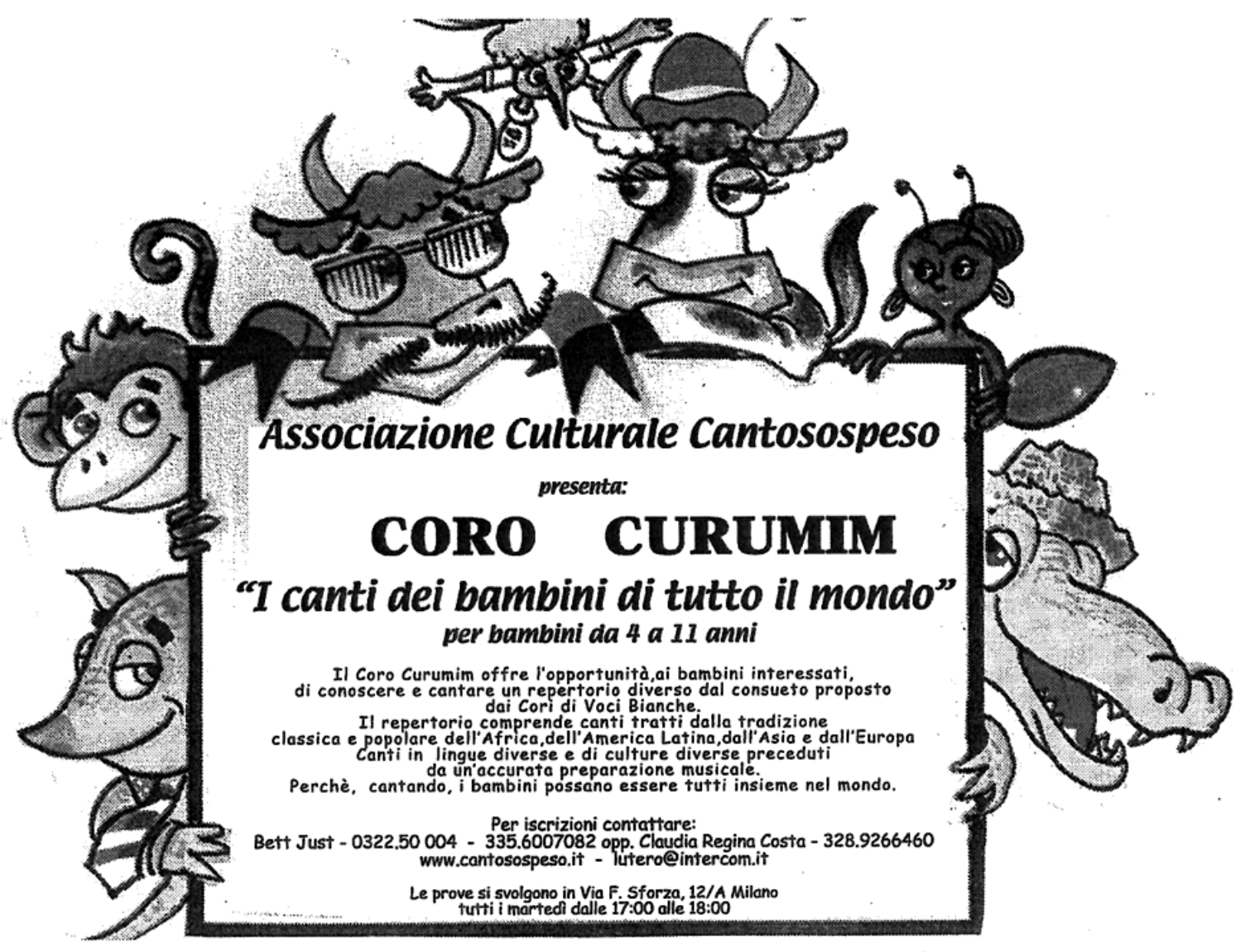




\section{ANEXO U}

\section{Programa de sala do espetáculo Vamos Brincar}

Vamos Brincar è il frutto di un lavoro iniziato lo scorso anno insieme ai bambini di alcune scuole e giovani volontari della citti.

Gli autori del progetto, sono artisti professionisti di origine latinoamericana, impegnati in Italia e in varie parti del mondo a valorizzare e comunicare la ricchezza e la bellezza delle culture del posto e dei popoli di Paesi di cui si conosce solo la povertà e ciò che i mass/media impongono.

Proponendo questo progetto agli insegnanti, ai direttori didattici, ai genitori, ai bambini, non avevamo nulla di preconfezionato, né intendevamo"selezionare" allievi dotati o altro. Lidea era e rimane quella di un itinerario di scoperta, di espressioni culturali dei popoli africani, del Sud America, attraverso le loro leggende, i loro miti, la loro musica, la loro danza. Questo è l'impegno e lo scopo del Centro di educazione alla Pace, fin dalla sua nascita

Non abbiamo trovato chiusure o diffidenze, certo nulla è stato facile, la dipendenza di tutti noi da modelli pubblicitari non aiuta l'ascolto profondo, non attiva risorse, capacità personali, forse sconosciute ad ognuno, pronti solo al consumo, anche culturale.

Sono stati realizzati degli autentici laboratori con i bambini e gli adulti,lungo mesi di impegno e di attenzione, non abbiamo operato forzature, cercando di seguire i tempi ed i ritmi dei piccoli e che poi sono diventati anche i nostri; non dovevamo ottenere dei risultati brillanti e di successo.E' stato un camminare avendo nelle orecchie i suoni, le melodie di tante strade del mondo, i ritmi dei corpi di donne e uomini dalla pelle scura e poi i giochi ed i racconti di bambini dei villaggi avvolti dal sole e dai colori della natura. I nostri bambini hanno imparato a cantare in altre lingue, si sono incontrati con coetanei provenienti da zone diverse della citta, scoperto luoghi e strade - le nostre - che sembrano aver dimenticato la memoria.

Sono stati molti i momenti di grande lavoro e di straordinarie emozioni; mano mano il lavoro cresceva rendendo giusta l'idea di un racconto collettivo Crediamo di aver dato tutti insieme un contributo, per aiutare la crescita di una umanità che non odia l'altro perchè diverso da sé, che sappia indignarsi per le ingiustizie, le discriminazioni razziali, che sappia scoprise uno stile di vita in armonia con tutti gli esseri del creato.

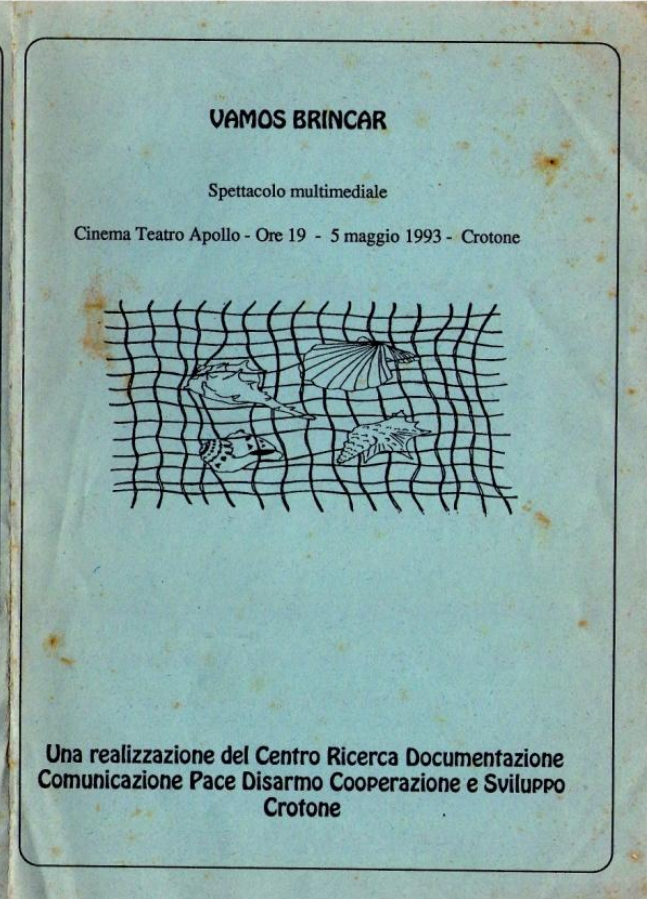

\section{Bambini partecipanti}

Per la danza: Giuseppina Diletto Enza Riillo Roberta Romeo Maria de Maio Flavio Martucci Giada Vrenna Maria A. Oppido Claudia Brunone Rito Lumare Valentina Galati Angela Rossano Manuela Franco Sergio Iritale Angela Arcuri Maria F.Adolfini Anna Maria Sorrentino Carmela Piccolo Le Borrelli Michela Maiolo Eugenia Oliverio.

Per la musica: Salvatore Renda Marica Arabia Daniele Marano Davide Mungari Maurizio Amendola Giada De Cicco Eleonora Oppido Luana Iorno Tommaso Sorrentino Mirco Loiacono Ramona Iorno A.Maria Scalise Francesco Parrinelli Nicola Provenzano Angela Le Rose Francesco Falbo Francesco Riillo Giuseppina Mesoraca Daniele Clausi.

Per il teatro: Maria Brugnano Maria Garà Paolo Mesoraca Domenico Aiello Giuseppe Fico Antonio Paluccio Paolo Minarchi Maria Savarelli Ramona Lumare Daniela Sestito Pasquale Longo Mario Ermano Alessandra Fiore Vincenzo Facino Giampaolo Lecce.

Si ringraziano, per aver creduto in questa idea ed attivamente collaborato, 1 insegnanti e gli insegnanti di Salica - Tifolo - S. Croce - Ises - S.Francesco, i bambini delle scuole sopra citate per la partecipazione al laboratorio di pittura collettiva del 30 aprile, realizzando anche con il loro impegno parte della sceneggiatura dello spettacolo.

Un grazie colmo di gratitudine ai Direttori Didattici Anili, Manganaro e Rossin alla Preside della Scuola Media Alcmeone per l'aiuto e l'accoglienza. Vivi ringraziamenti ai genitori per la partecipazione e la collaborazione. Si ringrazio no tutte le collaboratrici ed i collaboratori, per aver donato il loro tempo, la lor creativita, il loro lavoro attivo e gratuito.

Grazie infine a Sanzone Sport per la fornitura di alcuni elementi di scena.

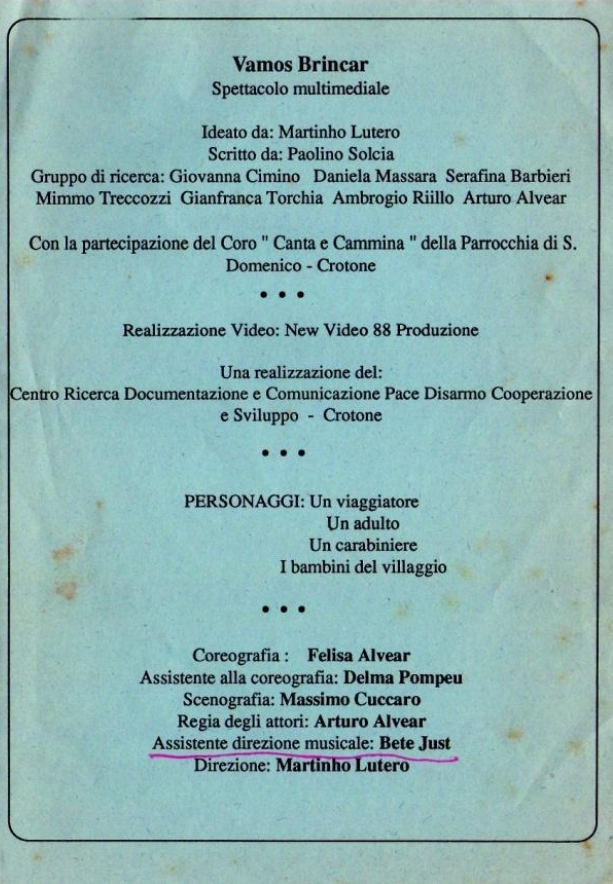




\section{ANEXO V}

Capa do programa de atividades em Quattro giorni nei dintorni di Bahia

attività collaterali

Incontro con la Cucina Bahiana Da Mercoledi a Sabato

dalle 18.00 alle 21.00

Cortile del Cineteatro San Lorenzo

Cibo, ricette e bevande tipici di Bahia e dei suoi dintorni saranno preparate da ragazze brasiliane.

Sabato 27 ore 13.00

pranzo speciale con piatti tipici preparati dagli artisti

protagonisti delle serate.

Letture al Tavolino

Da Mercoledi a Sabato

dalle ore 18.00 alle 21.00

Cortile del Cineteatro San Lorenzo

Lettura guidata di testi

di Jorge Amado:

sui tavolini del buffet saranno sparsi libri di Jorge

Amado per libera lettura e consultazione.

Un gruppo di ammiratori del romanziere vi aspetta con letture guidate sui temi più ricorrenti nelle sue opere. Aperto a tutti gli orari del buffet.

Spazio Mostra

Martedi ore 20.30

Sala Mostre del Cineteatro San Lorenzo

Apertura della Mostra di acquarelli dell' artista

bahiano "Carybé" con riproduzione dei suoi disegni sugli Orixàs del Candomblé.

La mostra rimarrà aperta da Mercoledi a Sabato

dalle 18.00 alle 21.00 .

Nello stesso spazio verranno trasmessi in video immagini di Bahia e delle sue feste tradizionali.

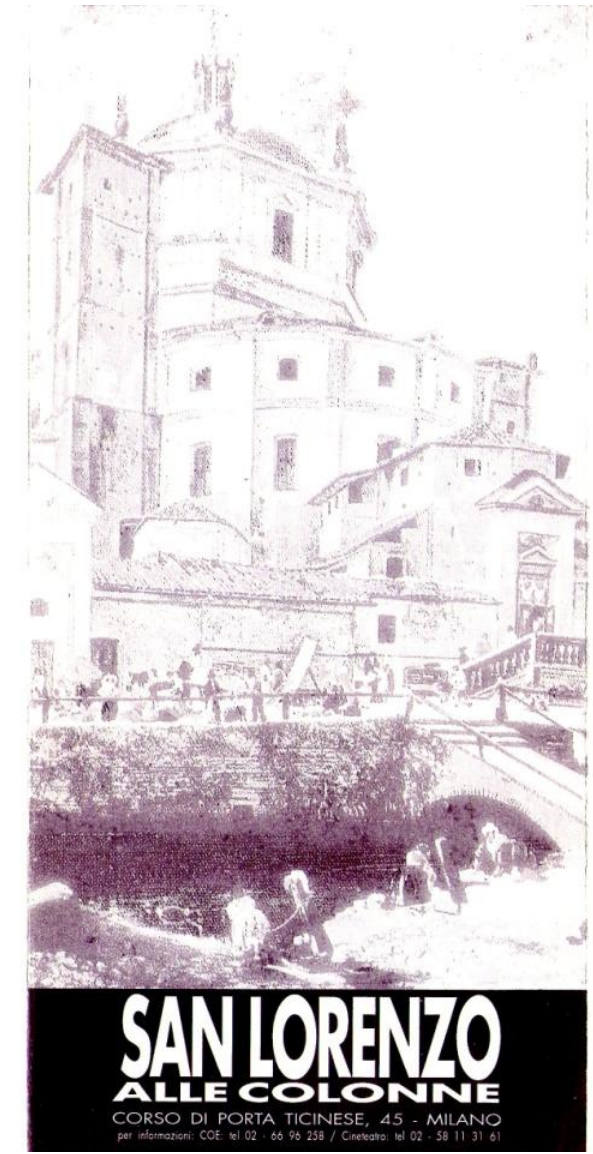

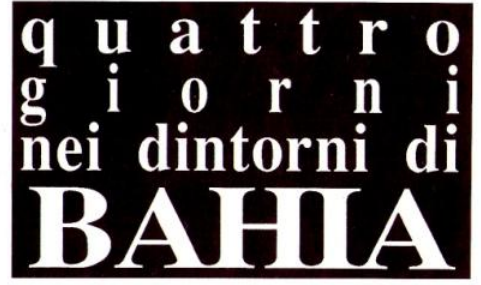

dal 24 al 27 maggio' 95 SAN LORENZO Alll COLONN:

C.so di Porta Ticinese, 45 - MILANO

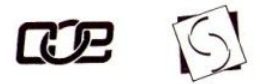

COe - centro orientamento educativo ASSOCIAZIONE CANTOSOSPESO 


\section{ANEXO W}

\section{Programação das atividades em Quattro giorni nei dintorni di Bahia}

Mercoledi 24 maggio 1995 ore 21.30 Cineteatro San Lorenzo alle Colonne

Ritratto d'autore: I Caymini : il compositore Dorival Caymmi e IB 21 in

Concerto-conferenza sulla musica di Bahia prendendo come tema principale la vita del compositore Dorival Caymmi, la sua produzione musicale e quella dei sue due figli, Danito Caymmi e Dori Caymmi. Dorival à considerato il cantore Bahia il corrispettivo di Jorge Amado per la musica popol del Nordest del Brasile. Ha scritto più di un centinaio di canzi canzoni basate Bra temi popolari della regione, raccontando la vila soffe lei pesca pepi nelle jung

La cantante brasiliana Rosa Emilia, il chitarrista Nenem Ribeiro ed il percussionista Kal dos Santos interpretano suoi brani più famosi con la partecipazione del Coro Cantosospeso, sotto la direzione artistica del $\mathbf{M}^{\circ}$ Martinho

Ingresso Lit. 5.000

Giovedi 25 maggio ore 20.00 San Lorenzo alle Colonne

FavoleIncantate

Lettura musicata della favola

"Gatto Tigrato e Miss Rondinella"

\section{di Jorge Amado}

unica opera dell'autore dedicata ai bambini. Per bambini adulti, il testo verrà presentato dagli attori Claudio Raimon e Cristina Rizzello, con la partecipazione del "Coro e Cristina Rizzello, con la partecipazione del "Coro Fabalalavos" dell'Associazione Culturale Cantosospeso
sotto la direzione di Martinho Lutero. Le maschere e la scenografia dello spettacolo sono state eseguite dai bambini della scuola materna Cesare Battisti coordinati dall'Associazione "Pensare con le mani".
Giovedì 25 maggio ore 21.15 alla fine della rappresentazione, seguirà un dibattito sui Bambini del Brasile guidato dalla pedagoga Rosana Cognolato, con la partecipazione dello storico José Luis del Roio e di rappresentanti del Consolato Generale del Brasile. Entrata Libera

Venerdi 26 maggio ore 19.30

Cineteatro San Lorenzo alle Colonne

Conferenza/Dibattito sul

\section{Candomblé}

principale religione afro-brasiliana, frequentata dai più alti rappresentanti della cultura di Bahia, quali Jorge Amado, Dorival Caymmi e lo storico francese Pierre Verger. Punto centrale del sincretismo religioso afro-americano, il Candomblés si afferma come la più forte religione portata dagli schiavi neri, molto seguita sia a Salvador di Bahia che Cuba.

L'incontro é guidato dallo storico brasiliano José Luis del Roio con la partecipazione di don Pietro Canova di Verona. Entrata libera

ore 21.30 sul sagrato della Basilica Capoeira e Roda de Samba

Spettacolo delle danze tradizionali di Bahia legate al Candomblé

con la partecipazione speciale di Mitokasamba Scuola di Samba di Milano e del gruppo di Capoeira do Baixinho. Entrata Libera

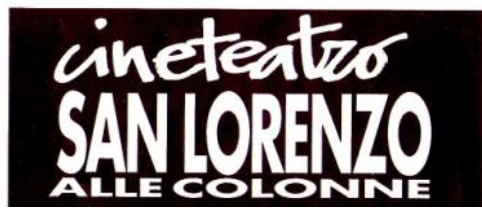

Sabato 27 maggio ore $\mathbf{1 5 . 3 0}$

Cineteatro San Lorenzo alle Colonne
Ingresso Lit. 3.000

"Tenda dos Milagres"

Film brasiliano degli anni ' 80 tratto dall'omonimo romanzo di Jorge Amado - Bottega dei Miracoli - Verrà proiettato in lingua originale (portoghese)) con traduzione simultanea in italiano.

ore 18.00

Cineteatro San Lorenzo alle colonn

\section{Jorge Amado}

Conferenza sull'autore intervallata dalla proiezione del video realizzato da Alberto Rollo dove Amado racconta Bahia, la terra e il mare.

Interverrà lo scrittore Luciano del Sette. L'incontro é

coordinato dalla rivista Linea d'Ombra.

Entrata Libera

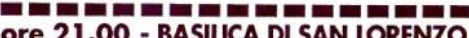
Grande concerto

cori Vu' Canta' e Cantosospeso dirige il $\mathrm{M}^{\circ}$ MARTINHO LUTERO

Concerto di chiusura del Maggio Milanese

e della Rassegna su Bahia

con musica brasiliana

e la rappresentazione della nascita di Yemanjà - dea delle acque nella tradizione sincretica afro-brasiliana.

Partecipano i musicisti Nenem Ribeiro - chitarrista, Kal dos Santos - percussionista, Mauro Orelio - violoncellista, Rosa Emilia - cantante e Delma Pompeo - danzatrice. La messa in scena della nascita di Yemanjà é curata da Kal dos Santos.

Ingresso Lit. 5.000 


\section{ANEXO X}

\section{Programa de sala do concerto IN-CANTO}

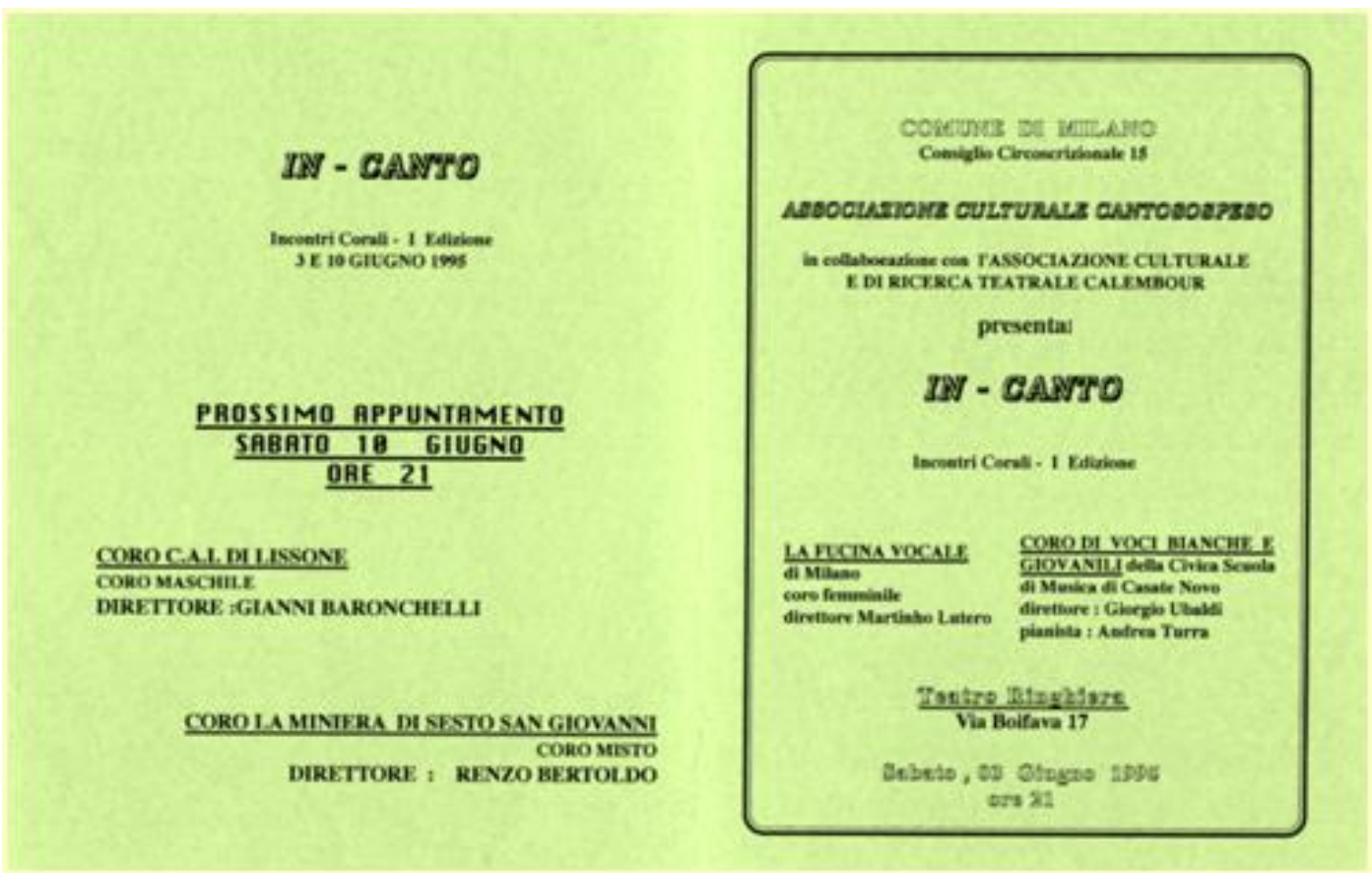

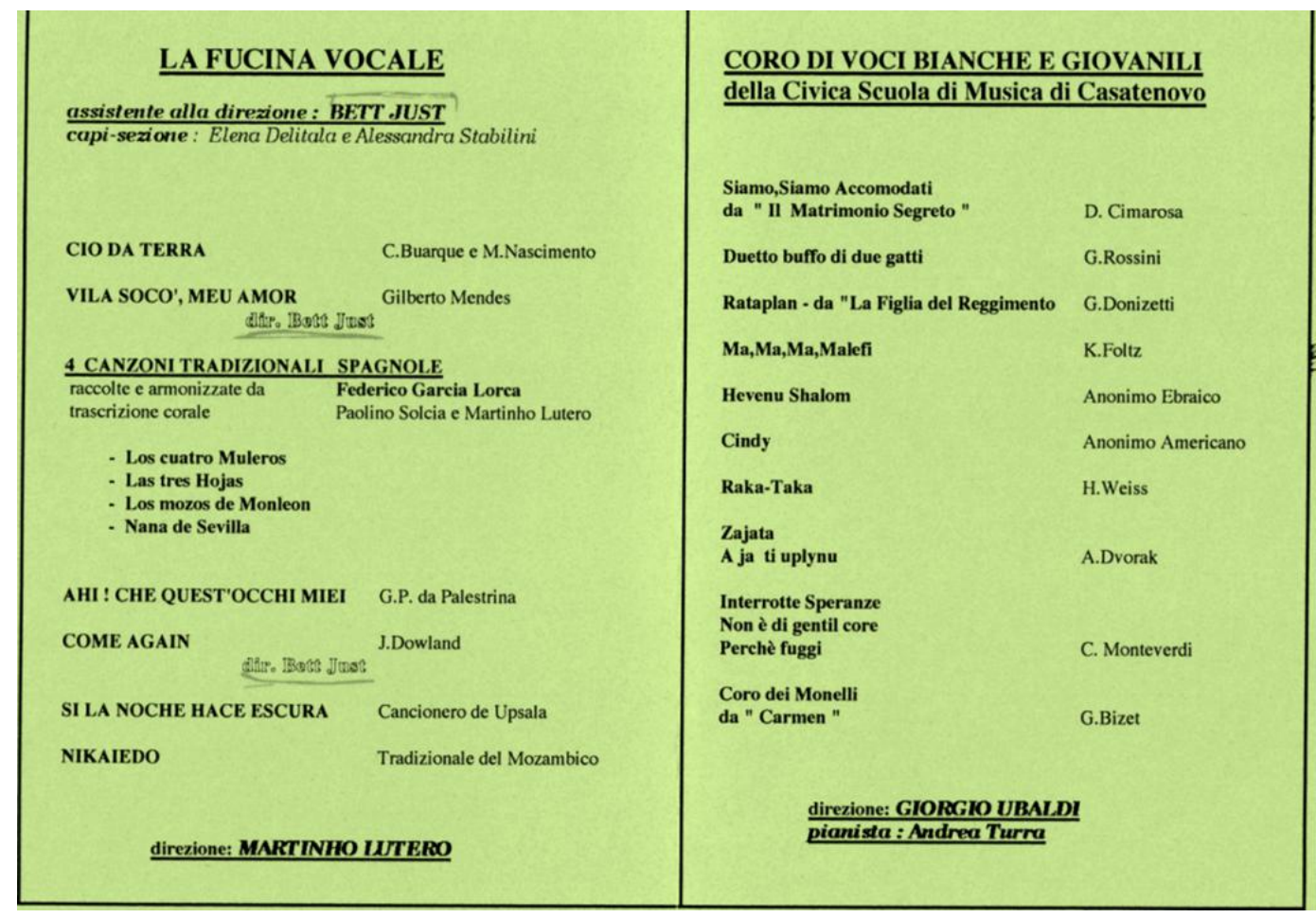




\section{ANEXO Y}

Programa do concerto Messa Luba com Kambilolo Group

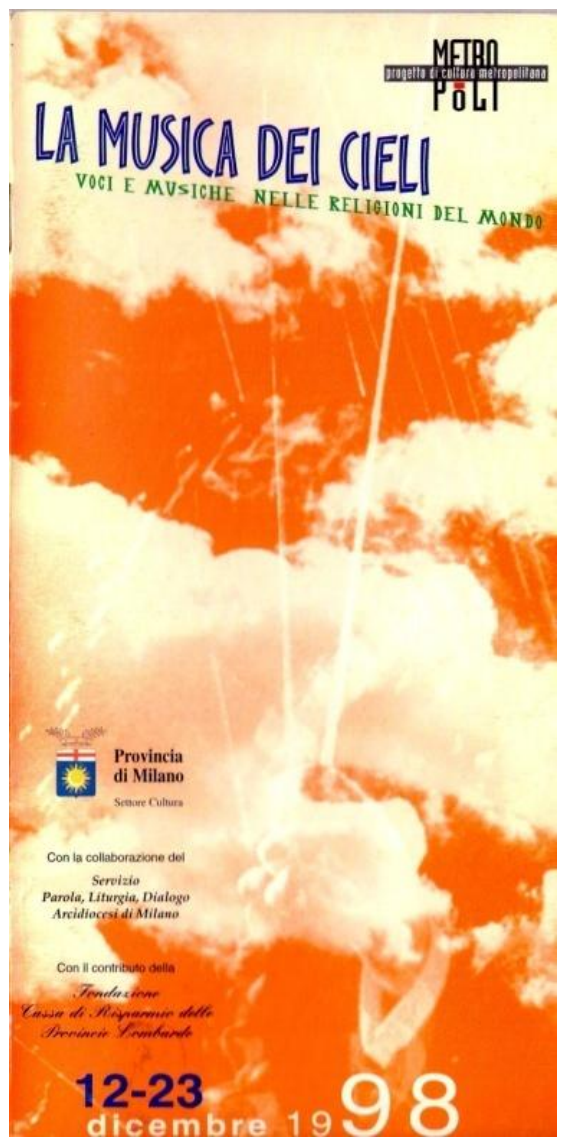

MESSA LUBA CON CORO CANTOSOSPESO

Ha una storia relativamente giovane alle spalle la Messa anni Sessanta, quando viene presentata a Kinshasa, da un folto ensemble, una cinquantina di ragazzi africani, assistit da una sezione di percussionisti e una quindicina il tentativo di trovare messa nu di incontro tra la musica atino, europea e quella africana: parti significative si possono ascoltare nella colonna sonora del film di Pier Paolo Pasolin "II Vangelo secondo Matteo" (1964)

L'edizione in calendario nella "Musica dei Cieli" viene affidat

II Coro Cantosospeso di Milano nasce nel gennaio 1987 tondato Lutero. L'obbiettivo primario è quello di illustrare e sviluppare un repertorio vocale in lingua portoghese, che via via si e mericana quindi fricana in particolare. Amenuisendo esperienza e prestigio il Coro

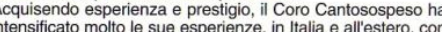
un organico di circa sessanta elementi.

La componente più strettamente africana del progetto sedici anni: appartengono alla etnia Giriama, una delle nove tribù che si richiamano alla lingua e alla tradizione Swahili. Lensemble proviene da Watamu, piccolo vilaggio a un comunit̀̀, i ragazzi del Group sono guidati e coor di musicista adulto, Daniel Kazungu, professore di musica

II Kambilolo Village Dance Group è giunto per la prima volta in Italia nel 1997. Si es esibito in festival e allinterno di chies crra d'origine, tra canti e danze, attraverso simboli e rith tipici della Grande Madre Africa

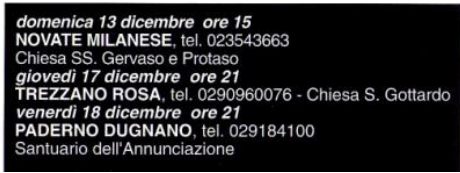
E KAMBILOLO GROUP Gessa Luba assicurata dal Kambllolo Village Dance trombettista con esperienza internazionale.

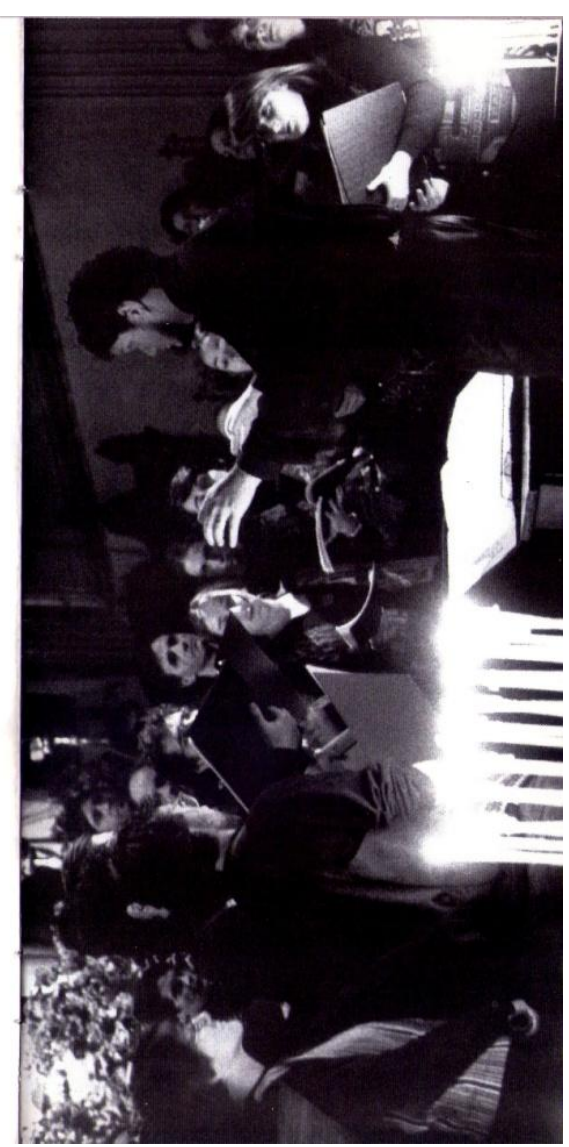




\section{ANEXO Z}

Publicidade de Girotondi e Filastrocche

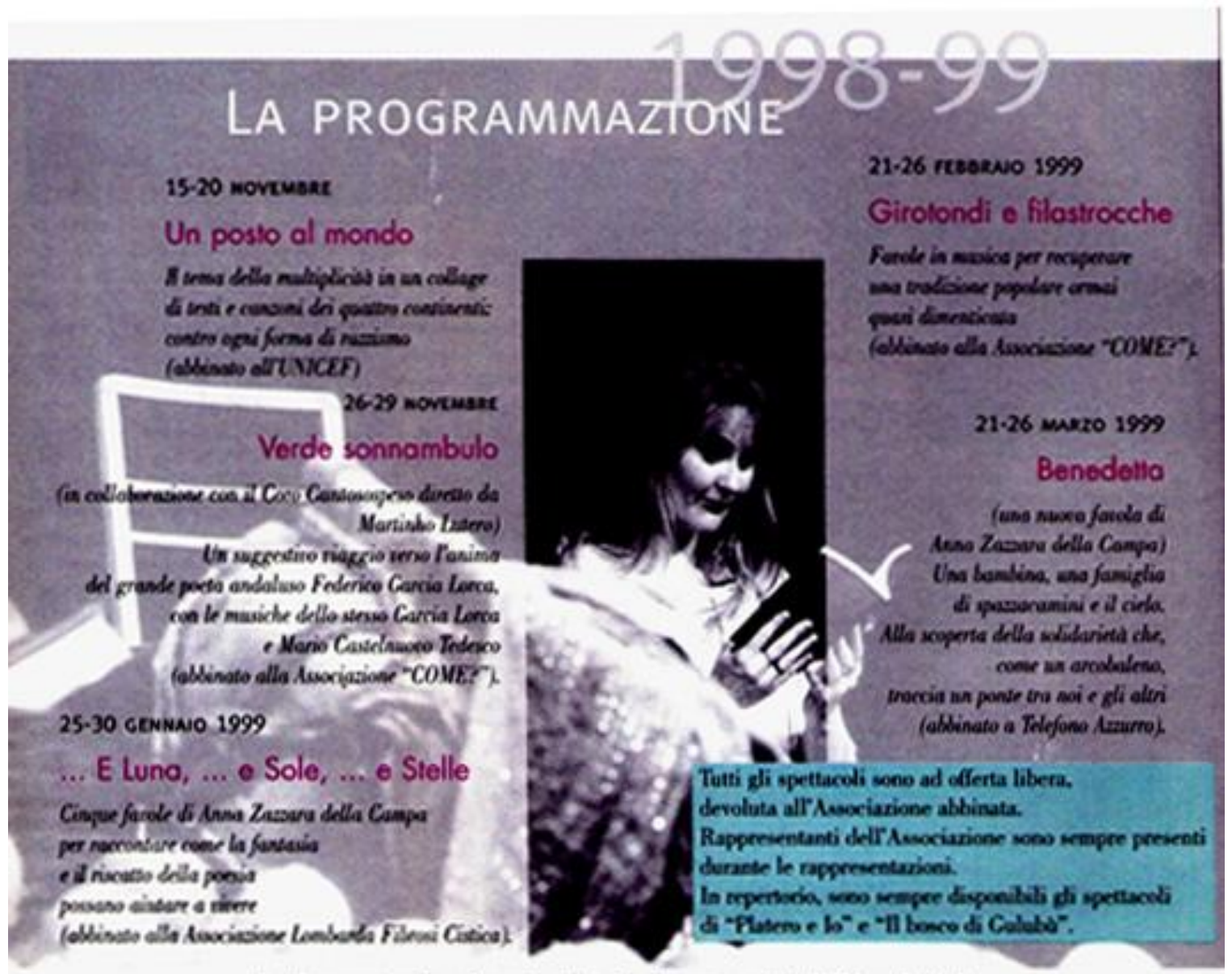

La drammaturgia e la regia di tutti gli spettacoli è di Ricardo Fuks.

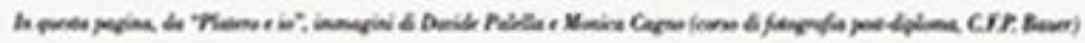




\section{ANEXO AA}

Atividades do laboratório de férias, Pincopallino, em 1998

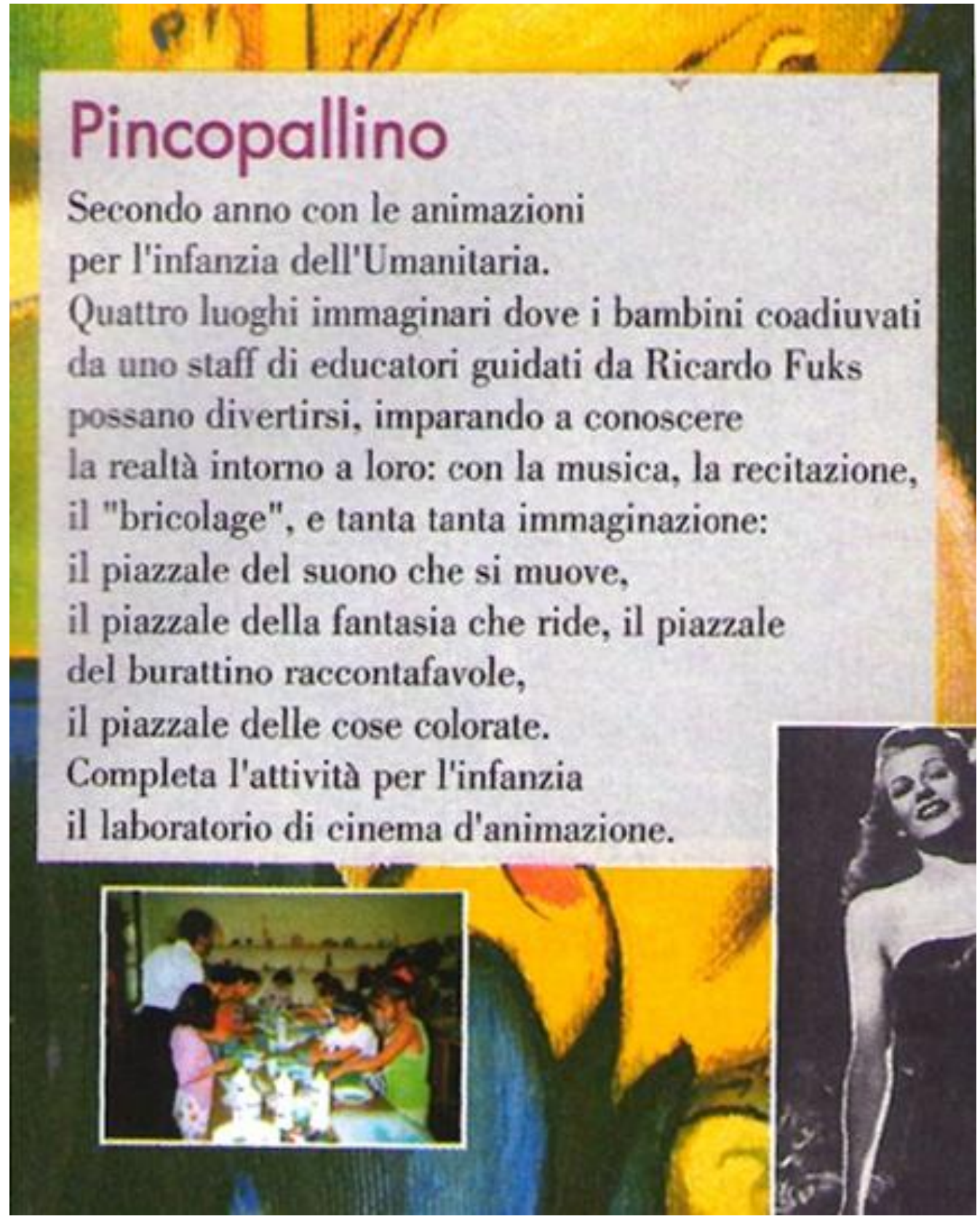




\section{ANEXO BB}

Comprovante de pagamento das atividades realizadas no laboratório de férias em 1998

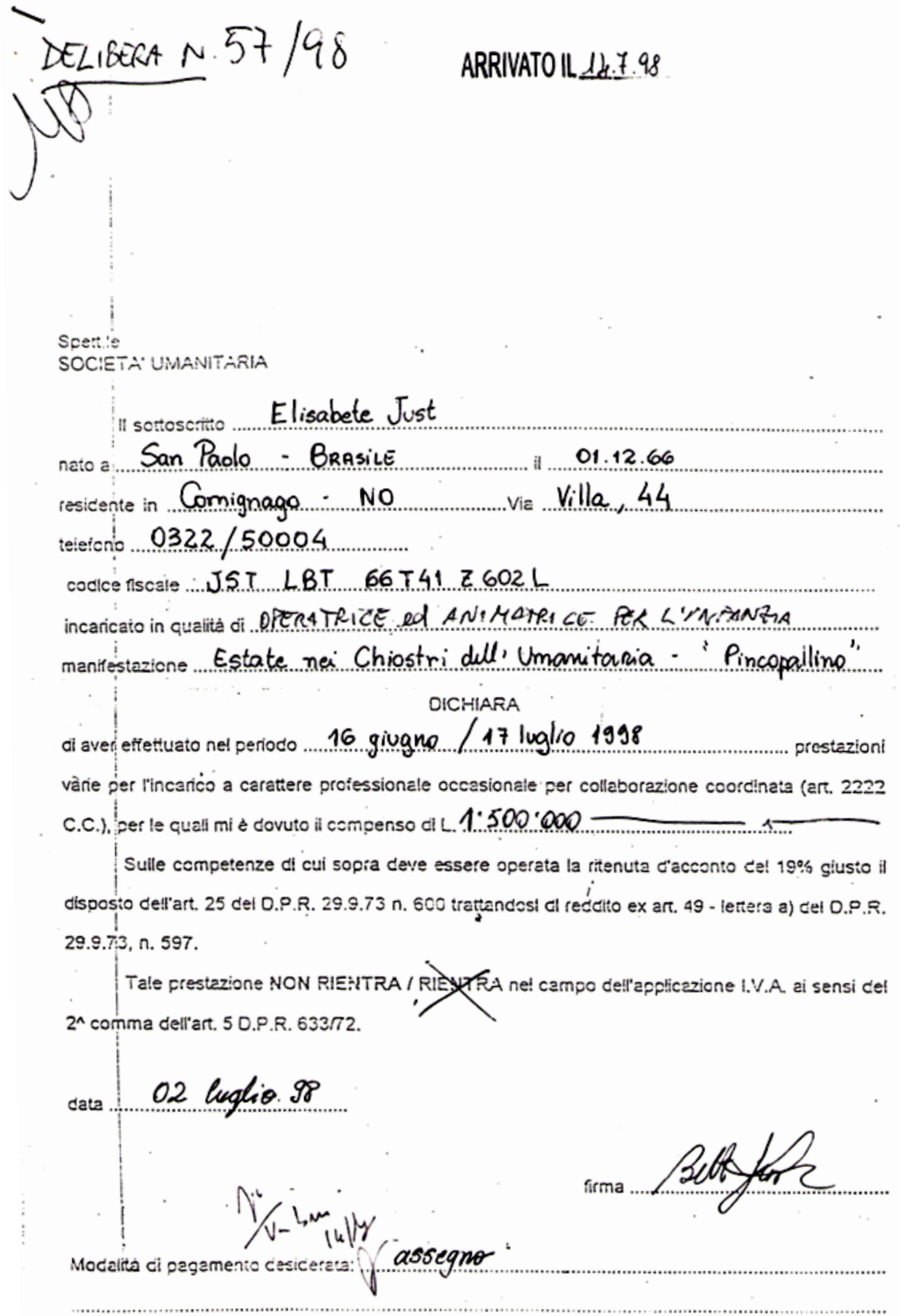

$M$. 


\section{ANEXO CC}

Publicidade do laboratório de férias, Pincopallino, em 2000

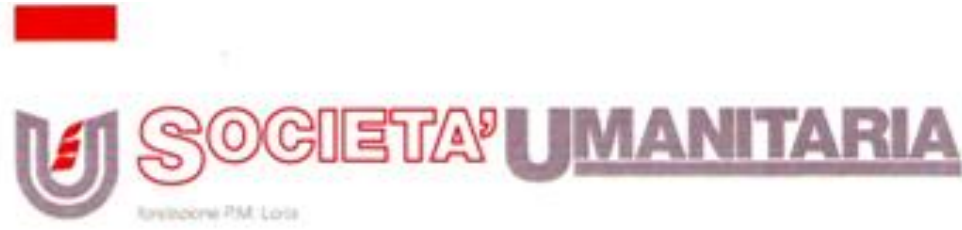

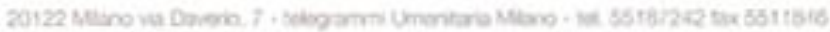

PiNCOPALLiNO nei CHIOSTRI percorsi di animazione estiva per bambini dai 4 ai 10 anni

dal 12 giugno al 21 luglio 2000

dal lunedi al venerdi, dalle ore 8.30 alle ore 17.00

STRUTTURA

8.30-9.30: accoglienza

9.30-12.30: laboratori e animazioni

12.30-14: colazione al sacco nei Chiostri

14.00-17: laboratori e animazioni

Attività

"INCONTRI"

con persone, luoghi, storie reali e immaginarie

Racconti e improvvisazioni teatrali, costruzione di ambienti e oggetti, musica, parole e suoni, linguaggio del corpo, costruzione e di burattini, costruzione di semplici strumenti musicali, cinema di animazione, percorsi di gioco strutturato accompagneranno i bambini in un itinerario ricco di sorprese e di avventure.

Come in un mosaico, i tasselli che ciascun bambino comporrà con la sua partecipazione a PiNCOPALLiNO nei Chiostri confluiranno in un lavoro la cui realizzazione costituirà una piacevole sorpresa al ritorno in città dopo le vacanze.

\section{Operatori}

Claudia Costa, Maurizio De Rosa, Annabella Di Costanzo, Beth Just, Elena Lolli, Giorgio Netti, Antonio Testa, Lorenzo Vitalone.

Ideazione, progettazione e coordinamento pedagogico

Graziella Liebermann

PINCOPALLINO

percorsi di animazione estiva per bambini dai 4 ai 10 anni

informazioni e iscrizioni: Società Umanitaria - Via Daverio, 7 Milano tel. 02/57/96.83.40 - 02/57.96.83.73 (Bruna Griziotti e Roberto Melogli) 


\section{ANEXO DD}

Percurso do laboratório de férias em 2002

\section{Canti degli Uomini}

Nel laboratorio di questa estate abbiamo iniziato le attività proponendo la seguente domanda:

"Di che cosa ne ha bisogno l'uomo per vivere?"

Una delle risposte più ricorrenti - mangiare - ha indirizzato la nostra scelta canora e i suoi "contorni": giochi sulla tecnica vocale, giochi sui parametri musicale, attività motorie, racconti e drammatizzazioni di fiabe, storie e leggende pertinenti al significato dei canti.

Cosa mangiamo, come mangiamo, dove cerchiamo il nostro cibo, chi lavora perchè possiamo mangiare...Tutto questo determina il nostro rapporto con la natura e con gli altri uomini.

Con i canti di alcune culture sparse per questo mondo, ci siamo avvicinati a questi rapporti : abbiamo cantato la crescita dei fiori (Zun Tin Lai), ci siamo messi nei panni degli schiavi africani che cantavano mentre erano obbligati a lavorare nel Nord America (Yonder come day), siamo caduti in mezzo alla foresta amazzonica mentre la tribù dei "Jabuti" ballavano e cantavano il rituale della pesca (Tche Nane) e finalmente siamo tornati in Italia per vincere le guerre - nel caso ci fossero - con i cannoni pieni di maccheroni (Piatto di Maccheroni). 
184

ANEXO EE

Programação do primeiro dia de atividades no Pincopallino 2002

Pincopallino estate 2002

Meecaldi 12 giugno

9:00/10 Acooglienza - nomi

9:10/15 Spriegazione sul labonatorio $\rightarrow$ la voce ne tlle diveese culture pantendo dille nosthe rimilitutide

9:15/30 Cantellone RAZZA UMANA: quello che tulti gli nomini hanno in comune nel loso corko e quello che hane bino gno pin vivere 9:30/45 Centrallizzane nel conpo: movimenti $9: 45 / 10: 66$

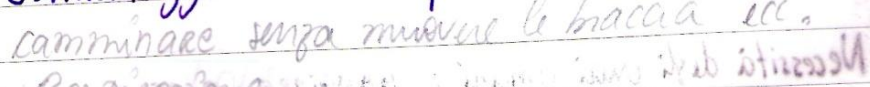
10:00/10:15 Treno giapsonere 10:15/10:30 CARTowaino (hol lis mo) yen tenere il

ComBiAMENTi:

9:0/9:10 - Accoglionza. vomi 9:10/9:15 - Speicgagione mul labonatorio - chi mono e cosa / memmo + carteletta 9:15/30 Carlllome RAZZA UMANA 9:30/45 Conpo/movimenti 9:45/10:00 Farola Cinose + canzone 10:00/10:30 Ventaglio

Oss: VAriabioni: 2 guppo non ha falto il chretecone 


\section{ANEXO FF}

Idade das crianças no laboratório de férias em 2002

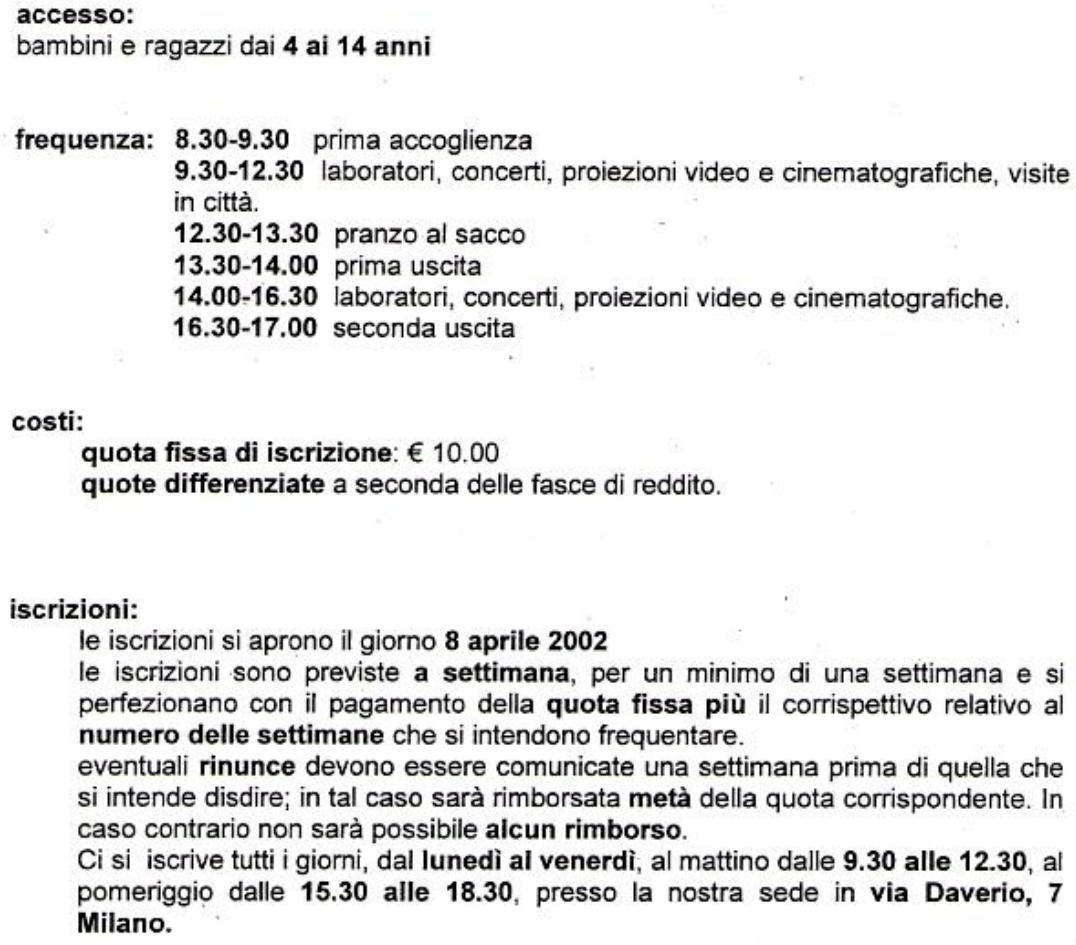

costi:

quota fissa di iscrizione: $€ 10.00$

quote differenziate a seconda delle fasce di reddito.

iscrizioni:

le iscrizioni si aprono il giorno 8 aprile 2002

le iscrizioni sono previste a settimana, per un minimo di una settimana e si perfezionano con il pagamento della quota fissa più il corrispettivo relativo al numero delle settimane che si intendono frequentare.

eventuali rinunce devono essere comunicate una settimana prima di quella che si intende disdire; in tal caso sarà rimborsata metà della quota corrispondente. In caso contrario non sarà possibile alcun rimborso.

Ci si iscrive tutti i giorni, dal lunedi al venerdi, al mattino dalle 9.30 alle 12.30 , al pomeriggio dalle 15.30 alle $\mathbf{1 8 . 3 0}$, presso la nostra sede in via Daverio, 7 Milano.

mostra:

a settembre è prevista una esposizione dei lavori fatti dai bambini durante l'Estate.

informazioni:

ai numeri: tel. 0257.968 .340 - 0257.968.349 - 025.796.831

fax 025.511.846

sito internet: $\mathbf{w}$ w w . umanitaria . it

Con il contributo di:

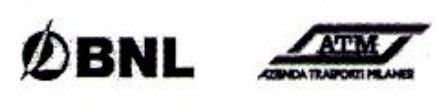




\section{ANEXO GG}

Objetivos do laboratório de férias em 2000

\section{Pincopallino Estate 2000}

\section{Fiabe e suoni amazzonici}

L'obiettivo di quest'attività è svegliare la curiosità dei bambini verso l'Amazzonia, offrendo degli spunti di cultura generale sull'area : gli abitanti, la "architettura", i principali fiumi, la fauna e la flora tramite i racconti delle principali favole amazzoniche, canzoni e improvvisazioni di suoni, il tutto presentato in forma ludica e con tanti giochi musicali come intermezzo.

Ogni settimana avrà come tema un animale, una pianta $o$ un personaggio tratto delle fiabe indigene e le attività si svolgeranno intorno ad esso : ascolto musicali, sonorizzazioni delle fiabe, rappresentazione grafica e corporale dei personaggi o ambienti scelti.

Bett Just

Claudia Regina Costa 
187

ANEXO HH

Anotações sobre o início do laboratório Fiabe e Suoni Amazzonici

$\rightarrow$ Ambientacáo: sons da floresta sons dos passurinhos cangōes indigenas
Africa/Am.Sul/ Australia Gondwana

$\rightarrow$ Coms fazer pana introduzin as criausas is floresta. amozónica?

- Pegar um barco para chegar na sala.

- Nesiste nada, temos que construir a Amazónia.

PoMas o que tèm na 'Amazonia? (Pengustar pras criaucas)

Che tipo di vegetazione? Quali sono glianimali? Gi sono inselti? Ci sono esseri umani? 


\section{ANEXO II}

Adaptação em italiano, livre e resumida, feita pela mestranda do conto $\boldsymbol{O}$ menino que não sabia sonhar de Daniel Munduruku

\section{II bambino che non sapeva sognare}

II Paje, un signore molto in gamba che prendeva la responsabilità di guidare il sto popolo, guardava con tanto amore il bambino appena nato.

"Cosi piccolino e so gia cosa diventera" -pensava il Pajc, "Questo bambino sara l' crede c guardiano della cultura del nostro popolo. Saprà consigliare la nostra gente con sapienra e giustizia, saprà curare le nostre malattie c rendera vive le conoscenze di questa comunita".

Si rivolse verso i genitori del bambino e gli disse:

"Mici parenti, ho il cuore pieno di felicità perche mi ésvelato nei sogni la volontà dei nostri saggi antenati : il vostro picoolo sara il nuovo Paje quando io $\mathrm{menc}$ andrò insieme agli altri spiriti. Ma perche questo si avere, ho bisogno del vostro consentimento nella cducazione che darò al bimbo".

I genitori sapevano che questo faceva parte delle tradizioni e se rifiutasscro la proposta del Paje, si prenderebbero la responsabilitì di non amonizzare l'Universo, e quindi, acoetieranno la facoenda.

L'educazione del Paje consisteva in lasciare vivere il bambino

uguale a tutti gli altri da piccolo, c poi, quando incominciasse a crescere. li insegnerebbe i segreti dei sogni, del contatto con gli antenati, la cura delle malattie $\mathrm{e}$ tante altre picoole $\mathrm{e}$ grande cose che formerebbe un Pajé.

II bambino prese il nome da un sogno del Paje, perche questo chiese agli antenati, come fa con tutti gli altri bambini, come si chiamerebbe questo "curumim" dallo sguardo sveglio e tenero, con i suoi denti bianchi come la luce e la sua faccetina rotonda. In un sogno li apparve una grande luna piena che li sorrise, od ecco qua: il Pajé ha interpretato che gli antenati volessero che il bambino si chiamasse "luna che brilla sopra gli uomini", ciod, Kaxi.

Kaxi ha vissuto fino all'cti di cinque anni molto vicino alla sua mamma; la aiutava a svolgere le facende domestiche, a piantare, a cogliere la manioca, fare la farina, a scegliere nella foresta le piante medicinale. Quando cresoc un po', stava anche con il suo papa, e lo accompagnava alla caccia c alla pesca. I bambini della comunità giocavano c escguivano dei lavon d' accordo alla loro ctà : si bagnavano e nuotavano diverse volte al giomo nel fiume, imitavano i versi degli animali, si costruivano le loro arco c frecce, imparavano a fare dei vasi con il lianc, imparavano a pescare c a cacciare. Vivendo in mezzi agli adulti, lavorando insieme a loro ma potendo anche giocare con gli altri bambini, imparavano a gestirsi da soli. Tutte le giornatc crano diverse una delle altre $\mathrm{e}$ il lavoro $\mathrm{c}$ il gioco non crano mai regolati da un'oraria : gli indios non utilizrano l'orologio. Un giomo andavano a lavorare maltina presto, altri al pomeriggio e altri ancora restavano a casa a chiacchicrare e ridere con gli altri. Alla sera, di solito, dopo il bagno nel fiume, tutti si riunivano intomo al fald in mezzo al terreno c parlavano di tutto: politica, barzellette, storic degli croi.

Kaxi capiva che vivendo cosl era istruito nel modo di vivere del suo popolo c gli sembrava strano che i bambini bianchi dovessero andare in un posto che si chiamava scuola per imparare la loro cultura. " Come riescono ad imparare a rispettare la natura se mon sono mai statc in una foresta? Come fanno per imitare il verso degli uceclli se non li sentono mai? Perché devono stare lontani dai suoi genitori?".

Kaki ancora non sapera che il bambino bianco imparava altre cose, diverse delle sue, perché nelle citza non esistono le foreste, e che si fa fatica a sentire gli vecelli, e che i genitori dei bambini sono costretti a lavorare in posti dove non possono, purtroppo, portare i suoi piccoli.

E cosi cresceva Kaxi, in merzo alla natura, insieme alla sua gente e con i suoi incontri con il Pajé. Lui li insegnava delle cose bellissime tramite le favole che li mecontava : queste storie erano la base della loro civilta. Ma un giomo, il Paje li parlo dei sogni, c Kaxi non sapera sognare.

"Paje, cosa faccio? Ho tanti dubbi. So che sono stato seclto dagli antenati per guidare il mio popolo, ma non ho idea di come farlo, non so neanche sognare!" 
"Non preoccuparti, Kaxi, molti Pajé avevano dei dubbi e molti non sapevano sognare. Vedrai che quando riuscirà a sognare, ti sembrerà più comprensibile la strada da prendere".

II Pajé preparò una bibita con la cacca del tapiro e diede a Kaxi.

"Prendela. Questo ti servirà soltanto come aiuto ma per poter sognare da solo, cerchi di sentirti libero".

Kaxi aveva già compiuto dodici anni, $\mathrm{e}$ insieme agli altri contemporanei, era ora di farc il rituale di passaggio all' età adulta. Andavano tutti alla foresta e li rimanevano finche non avessero cacciato un grande animale per portare alla comunita. Questa era la prova che potevano vivere da soli, c quindi, diventare adulti.

Ed d arnivato il giomo: hanno ballato, mangiato, cantato tutti, $\mathrm{c}$ alla fine della festa un gran silenzio arrivo. Era il momento di partire, e decine di ragazzi corsero verso la foresta, soltanto con i suoi archi e frecce, i suoi corpi adomati del seme di urucum e tanta voglia di tomare con una bella preda. Piano piano il gruppo si disgregava, tutti sapevano che la esperienza era fatta da soli, c ad un tratto Kaxi si senti solo. Lui era tranquillo perche sapeva che non tutti nuscivano a superare questa prova nella prima volta, e si poteva rifare tante volte fosse necessario. $\mathrm{Nel}$ primo giomo non ha mangiato niente, nel secondo solo frutta, $\mathrm{c}$ ncl terzo, da solo, in mezzo alla foresta, non aveva neanche acqua da prendere.

Era affamato, aveva sete, era stanco di tanto camminare ma non vedeva nessun animale da caccia. Non voleva arrendersi, ma ha penso:

"Va benc, posso lasciare per la prossima volta. Adesso mi riposo qua e quando mi sveglio torno a casa". Es' addormento.

Per la prima volta, ha fatto un sogno: Nel sogno s' incontrò col Pajé. Kaxi entrò nello spirito della onça ed ha corso veloce in mezzo alla foresta. Entrò nel cuore del mondo c vide dove si nascondeva la caccia. E' andato alla fine del mondo ed ha visto uomini e macchine distruggendo gli alberi, scavando la terra, togliendo le bellezze del suolo; di seguito si trasformò in un aquila c volo sopra i fiumi c alberi. E' diventato serpente e strisciò nelle "cope" degli alberi. Entrò nello spirito delle piante e alberi e senti il suo dolore c pianto. Si trasformo in pesce per sentire il dolore del fiume inquinato. Ha visto anche il suo popolo in dolore, che mettevano dei vestiti per coprire il copro, invergognandosi di andare in armonia con la Madre Tcrra. Ha visto tanta della sua gente affascinata dalla tocnologia dell'uomo bianco, sentendo la scatola che parla c inganna; ha visto due fratelli che litigavano per un pezzo di carta, ha visto dei guerrieri che diventavano schiavi dell'uomo bianco in cambio di un'acqua di sapore amaro.

Quando tornd al suo corpo, ha pianto, pianto tanto per tutto quello che ha visto.

Si sentiva debole, ancora stanco $\mathrm{c}$ affamato, pero si sentiva anche più preparato. In questo momento ha visto una forte luce in merso alla foresta e una faccia famigliare che li sorrideva al centro: era il Pajé. Davanti a tanta emozione nel sapere possedere una conoscen/a secolare, svenni.

Dopo alcune ore si sveglio, c come per magia, riusci a ricordarsi di tutto quello che aveva sognato. Non cra più stanco, cra leggero, felici, aveva lo spirito pieno, ma la pancia... aveva ancora un gran bel buco $\mathrm{h}$. Si alzo c cammino finche ha trovato un tapiro enorme che non si accorse della sua presenza. Con un colpo preciso, freccia il tapiro e lo portò a casa.

E cosi è diventato adulto. Un adulto che sogna, che si lascia sognare. 


\section{ANEXO JJ}

Esboço do cenário do laboratório Fiabe e suoni amazzonici

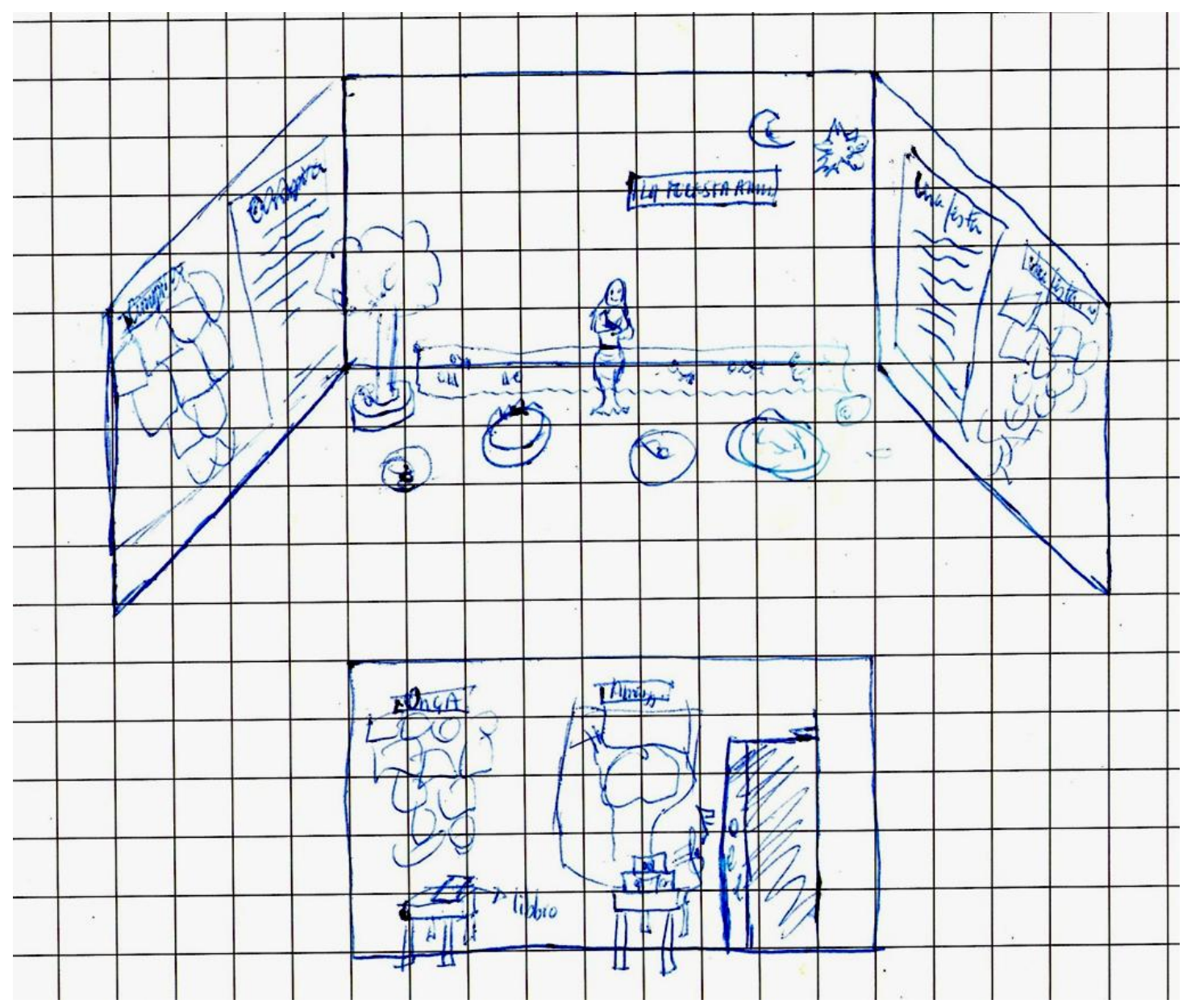




\section{ANEXO KK}

Número de crianças das atividades infanto-juvenis da SU em 2001/2002

Le Botteghe Permanenti 2001/2002

Le botteghe permanenti invernali e estive hanno visto la presenza di 400 bambini.

Sono stati organizzati laboratori per 630 bambini nelle scuole e corsi di formazione per insegnanti.

Iscrizioni

Da lunedi al venerdì, mediante versamento della quota di preiscrizione di Euro 26,00 dalle 9.30 alle 12.30 e dalle 15.30 alle 18.30 , presso la sede della Società Umanitaria, via Daverio $n$. 7, Milano.

L'iscrizione si perfeziona versando la quota complessiva presso l'agenzia n. 29 della Banca Nazionale del Lavoro in viaPace 10 - Milano.

\section{Informazioni}

ai numeri telefonici 0257.968.340 - 0257.968.349-0257.96.831

fax: 025.511 .846

Sito interet: www.umanitaria.it 
ANEXOS

Cap. 2 


\section{ANEXO LL}

Partitura de Bella Ciao (1)

Canção popular italiana

arranjo: Susan Lovegrove Graziano

\section{CANTO 29: 0 bella ciao!}

\section{8}

15

$a^{2}$

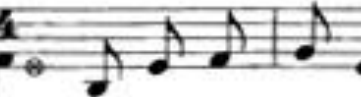

$\mathrm{U}$ - na mat - ti - na

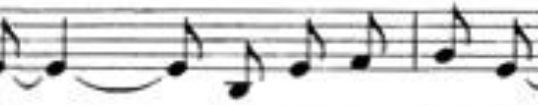

mi son sve - glia-to,

o bel - la

2
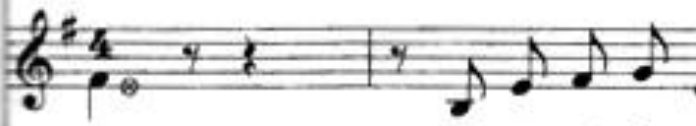

U - na mat - ti - na
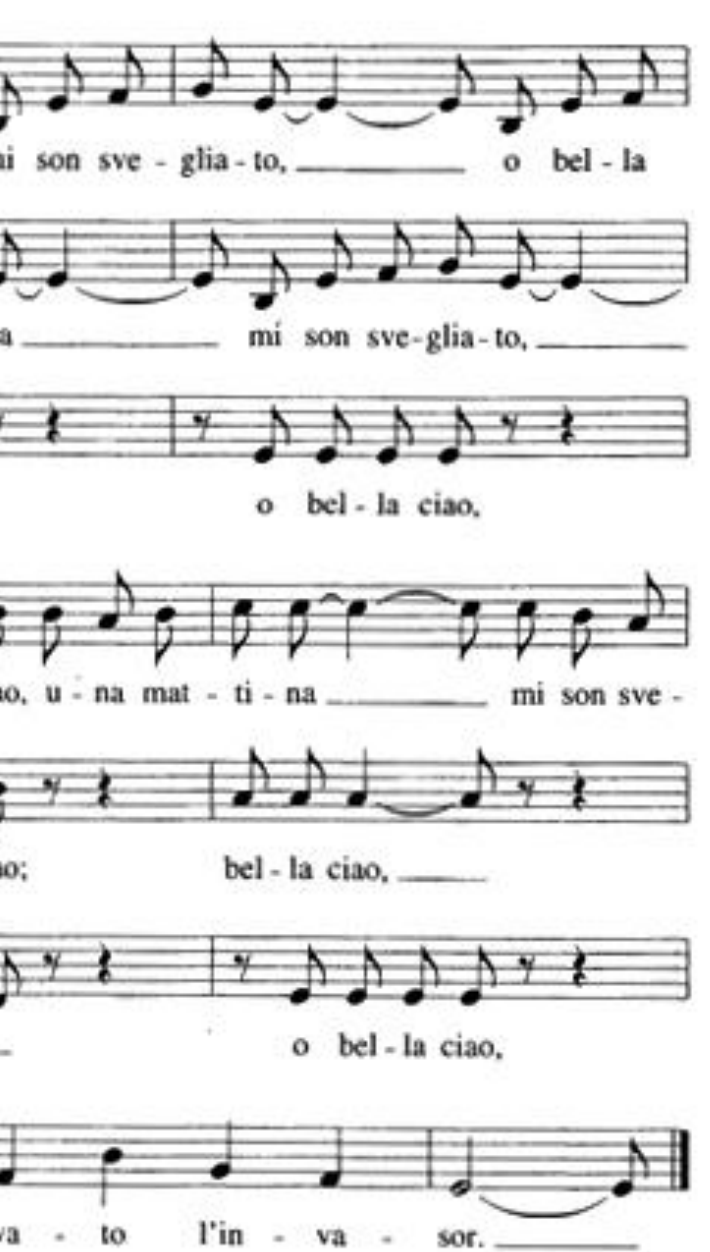

mí son sve-glia-to,

3

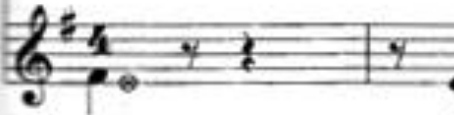

O bel - la ciao,

- bel-la ciao.

3

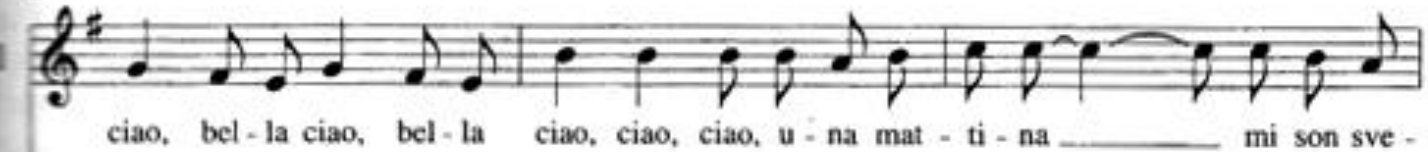

2

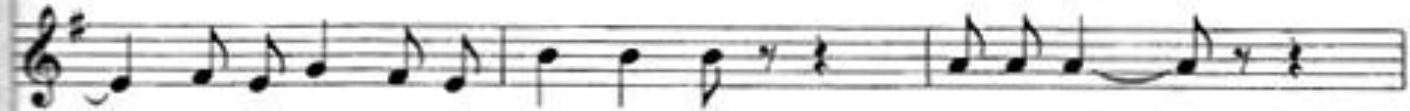
bel - la ciao, bel - la ciao, ciao, ciao; bel - la ciao.

3 $\frac{1}{8}$

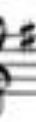

(2)
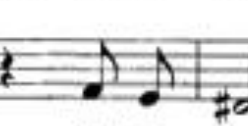

bel - la

ciao,

- bel - la ciao.

6

to
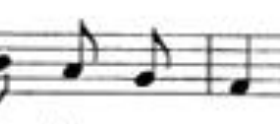

e bo tro - va - to

1'in - va - sor.

2

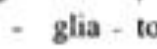

\section{(r)}

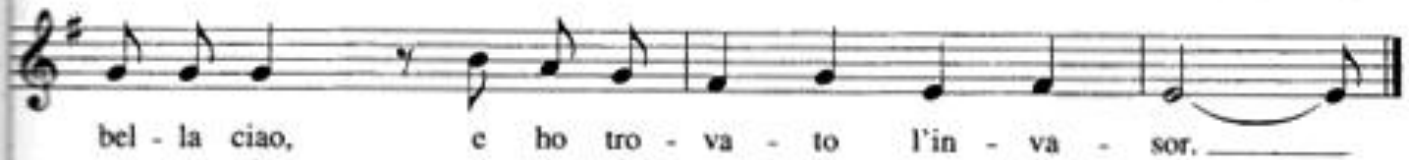

3

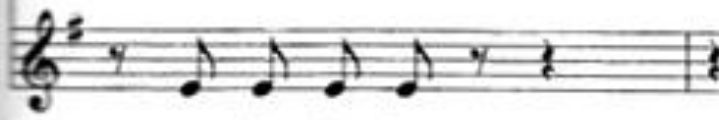

$$
\text { o bel - la ciao, }
$$

O partigiano portami via che mi sento di morir.

Ese io muoio da partigiano as mi devi seppellir.

Seppellire lassù in montagna sceto l'ombra di un bel fior.

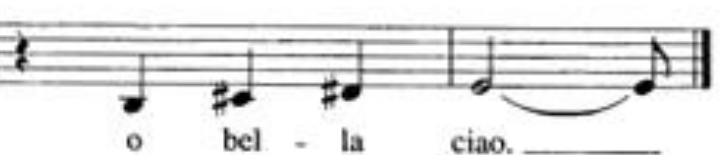

E le genti che passeranno e diranno o che bel fior.

E questo il fiore del partigiano morto per la liberta. 


\section{ANEXO MM}

Partitura de Bella Ciao (2)

Canção popular italiana

arranjo: Bett Just

BELLA CIAO

\section{Canto della resistenza italiana}
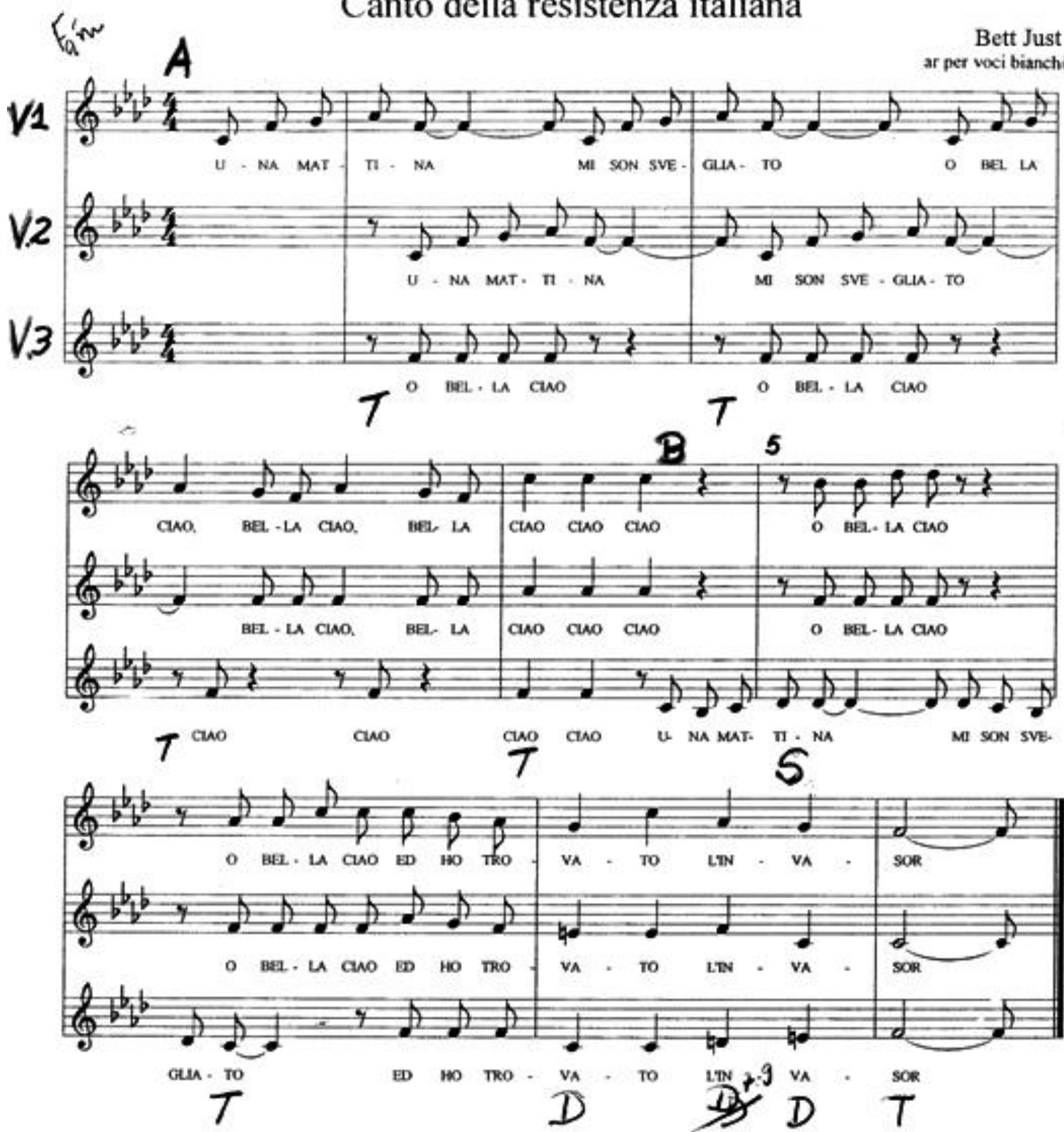

1. Una mattina mi son svegliato Ed ho trovato I'inwasor

2. O partigiano portami via che mi sento di morir

3. E se io muoio da partigiano tu mi devi seppellir
4. E seppellire lossù in montagno sotto l'ombra di un bel fior

5. Tutte le genti che passeranno e diranno o che bel fior

6. è questo il fiore del partigiano morto per la libertà 


\section{ANEXO NN}

Partitura de Cuckoo! (1)

Compositor: Benjamin Britten

Edição de 1936

\section{Cuckool : 1933}

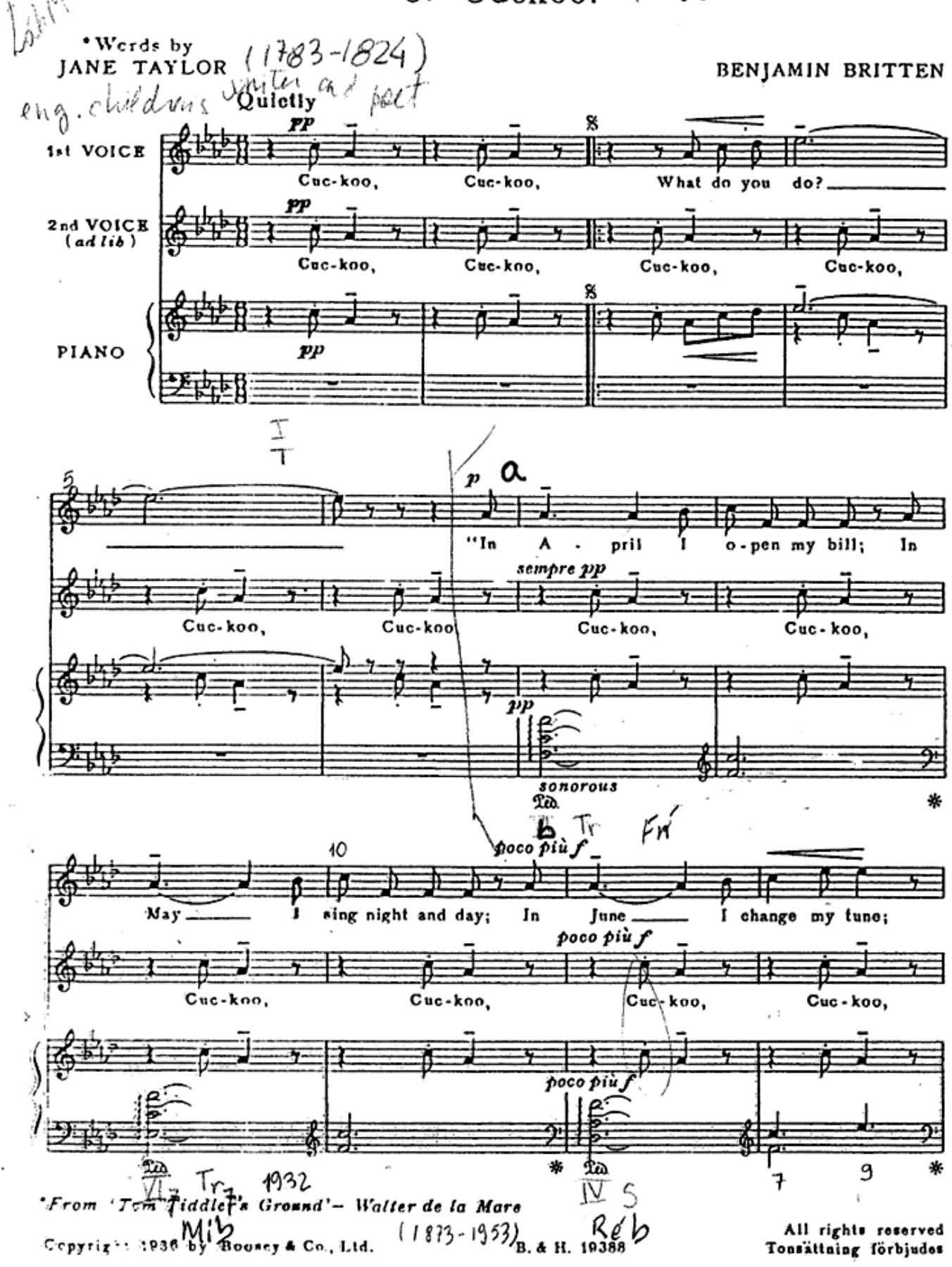




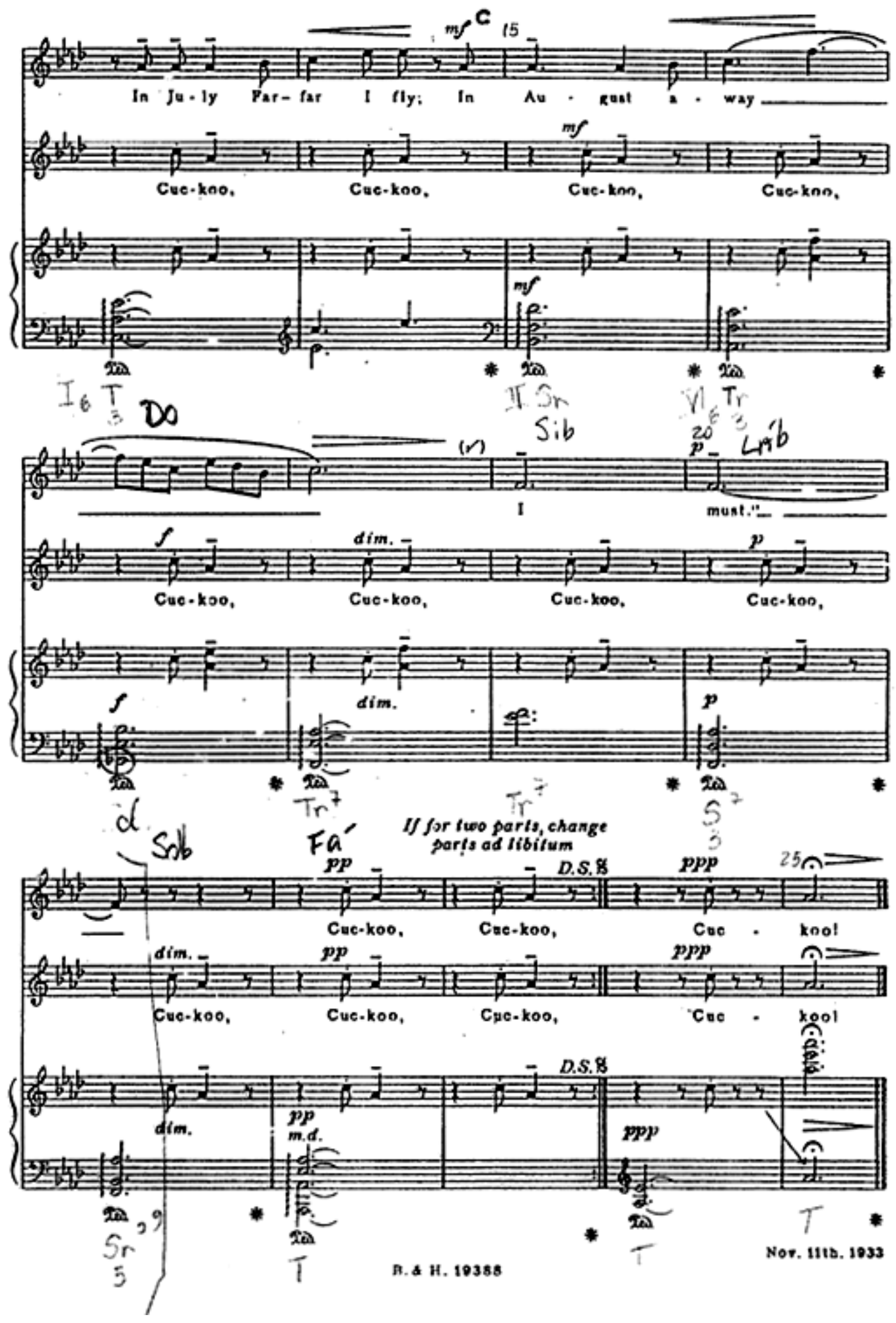




\section{ANEXO OO}

Partitura de Cuckoo! (2)

Compositor: Benjamin Britten

Adaptção: Bett Just

\section{CUCKOO!}
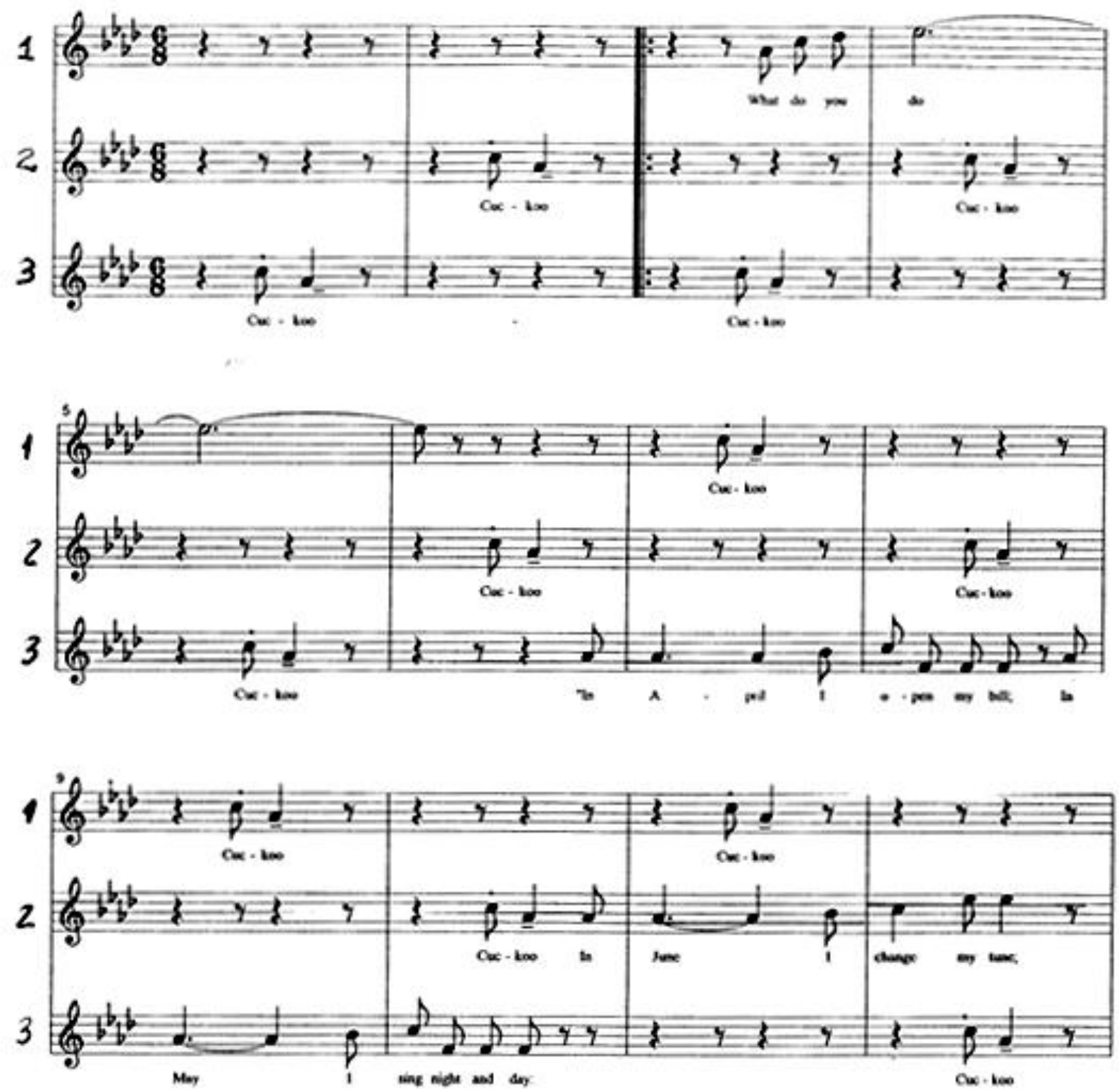

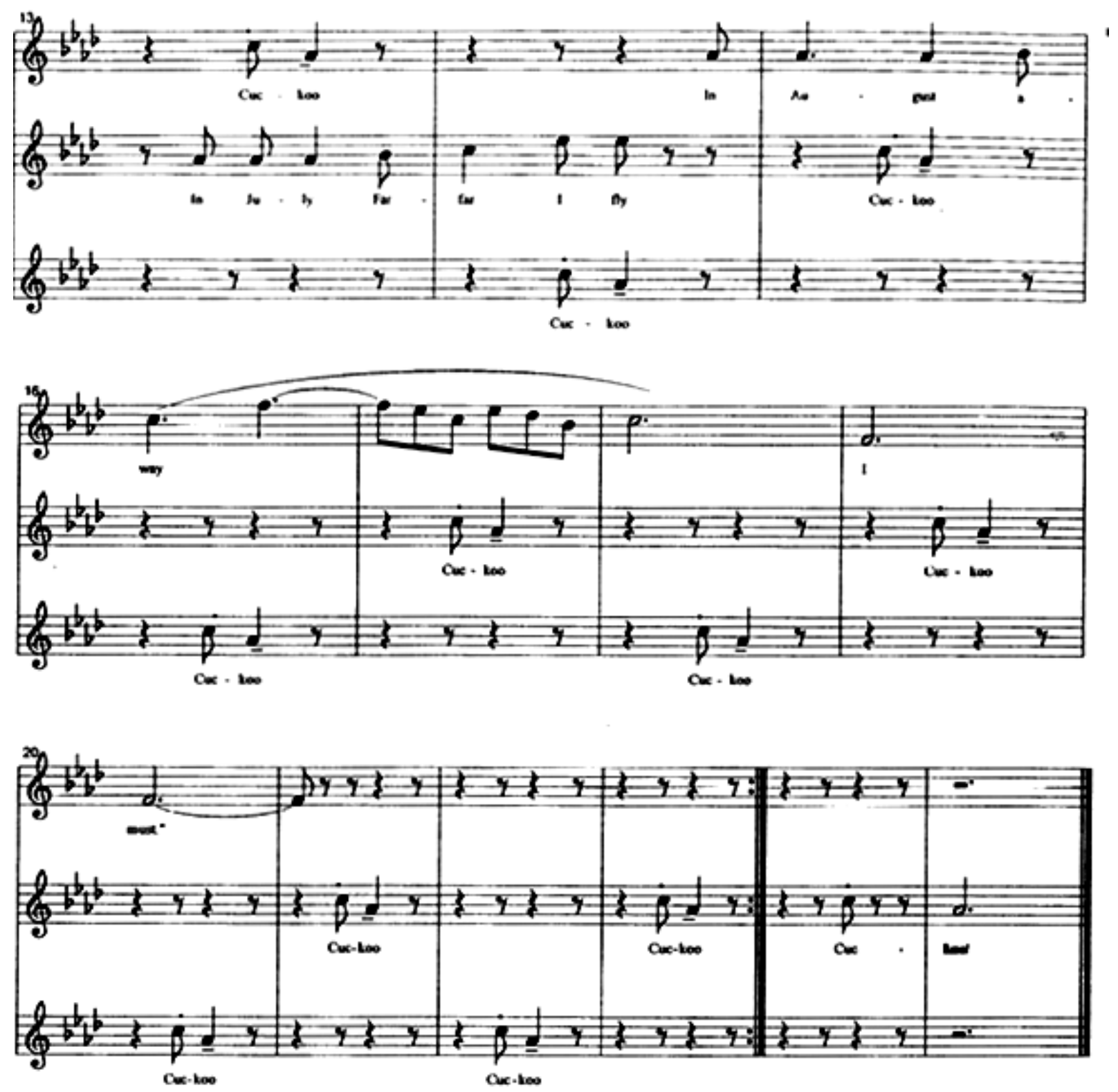
199

ANEXO PP

Partitura de Das Klinget so Herrlich Compositor: Wolfgang Amadeus Mozart Adaptação: Bett Just

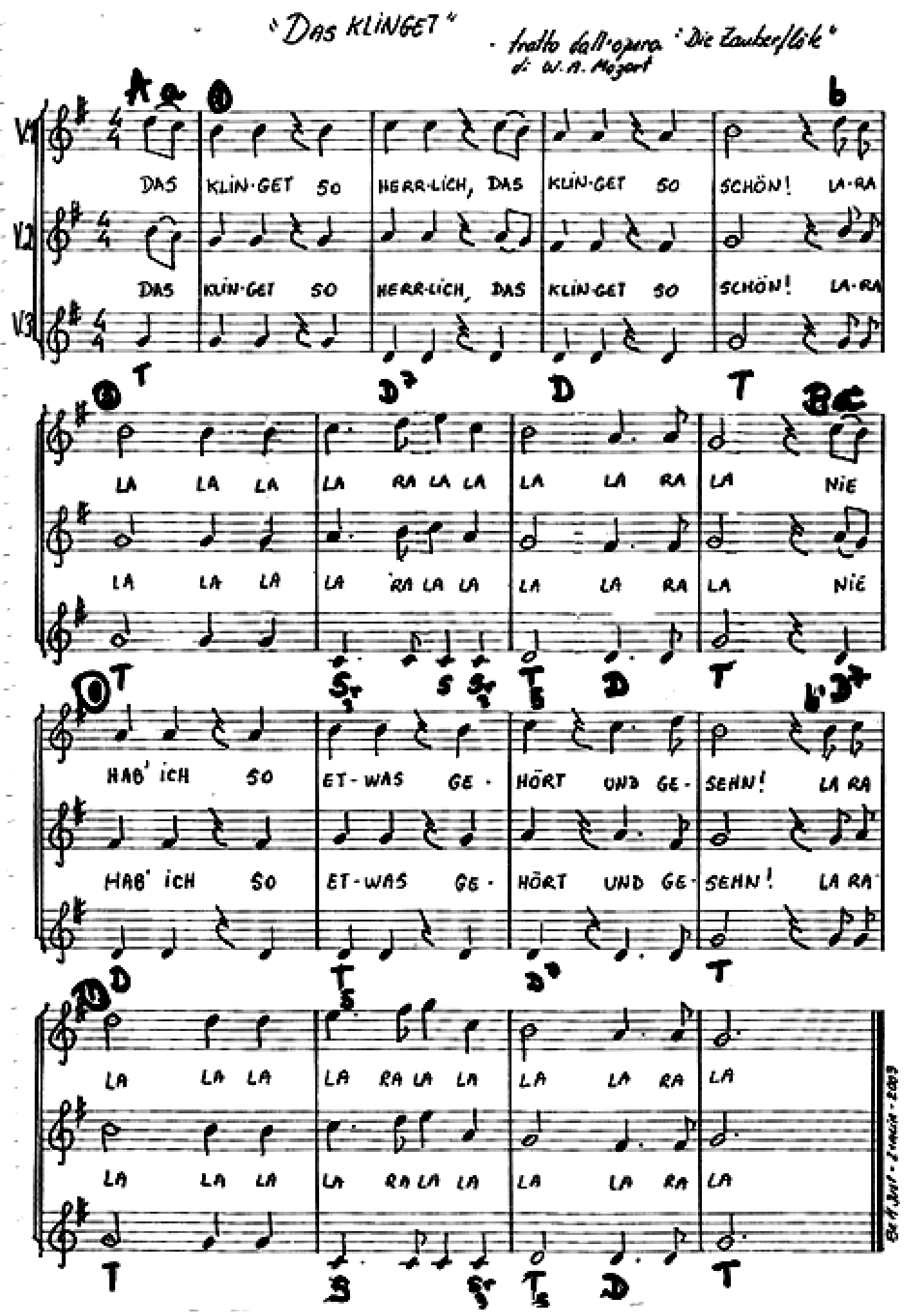




\section{ANEXO QQ}

Partitura de Mekô Merewá (1)

Canto tradicional dos índios Suruí de Rondônia

Adaptação e Arranjo: Marluí Miranda

MEKÔ MEREWĀ

INDIDS SURUII DE ROKDÔNII

$\downarrow d=120 \quad$ Adaptação e Arranjo: Marlui Miranda
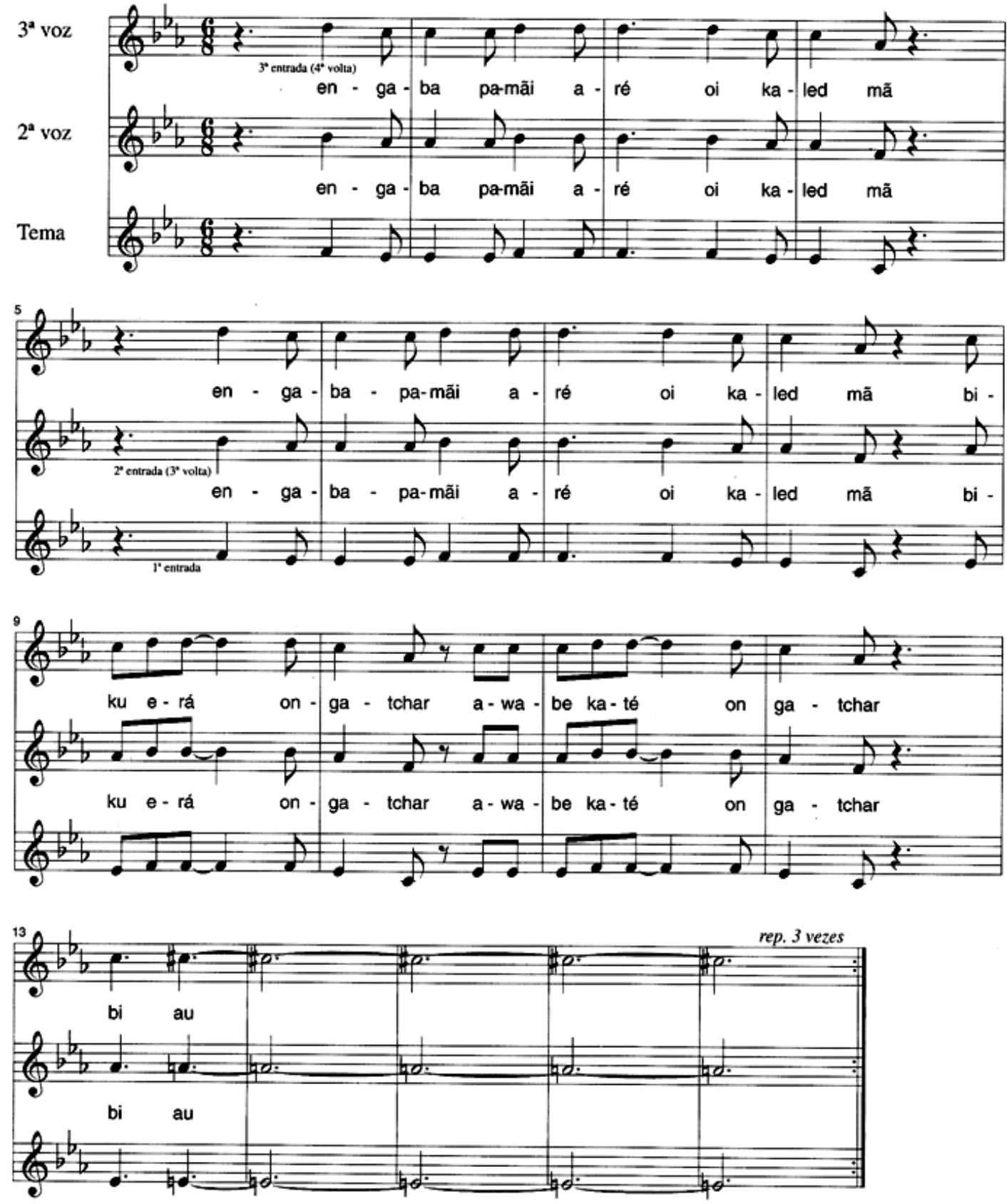


\section{ANEXO RR}

Partitura de Mekô Merewá (2)

Tema da canção Paiter Suruí recolhida por Marluí Miranda

Partitura com a ilustração de Laurabeatriz, extraída do livro Histórias de Índio de Daniel Munduruku
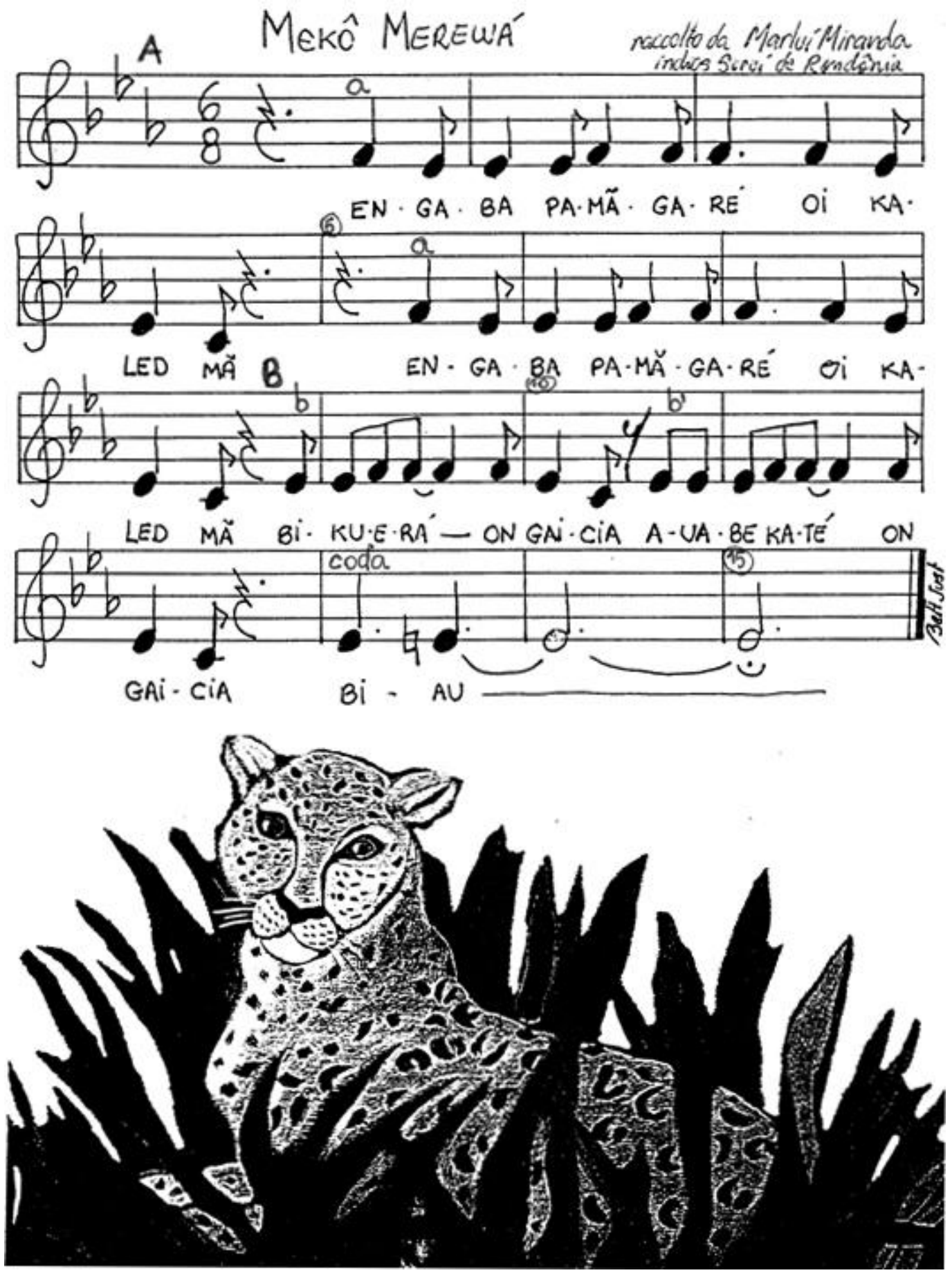


\section{ANEXO SS}

Partitura de N'Kosi Sikeleli Africa (1)

Composição: E. Sontoga e S. Majombozi

Arranjo: Martinho Lutero

Montagem de figuras feitas com as ilustrações do moçambicano Malangatana

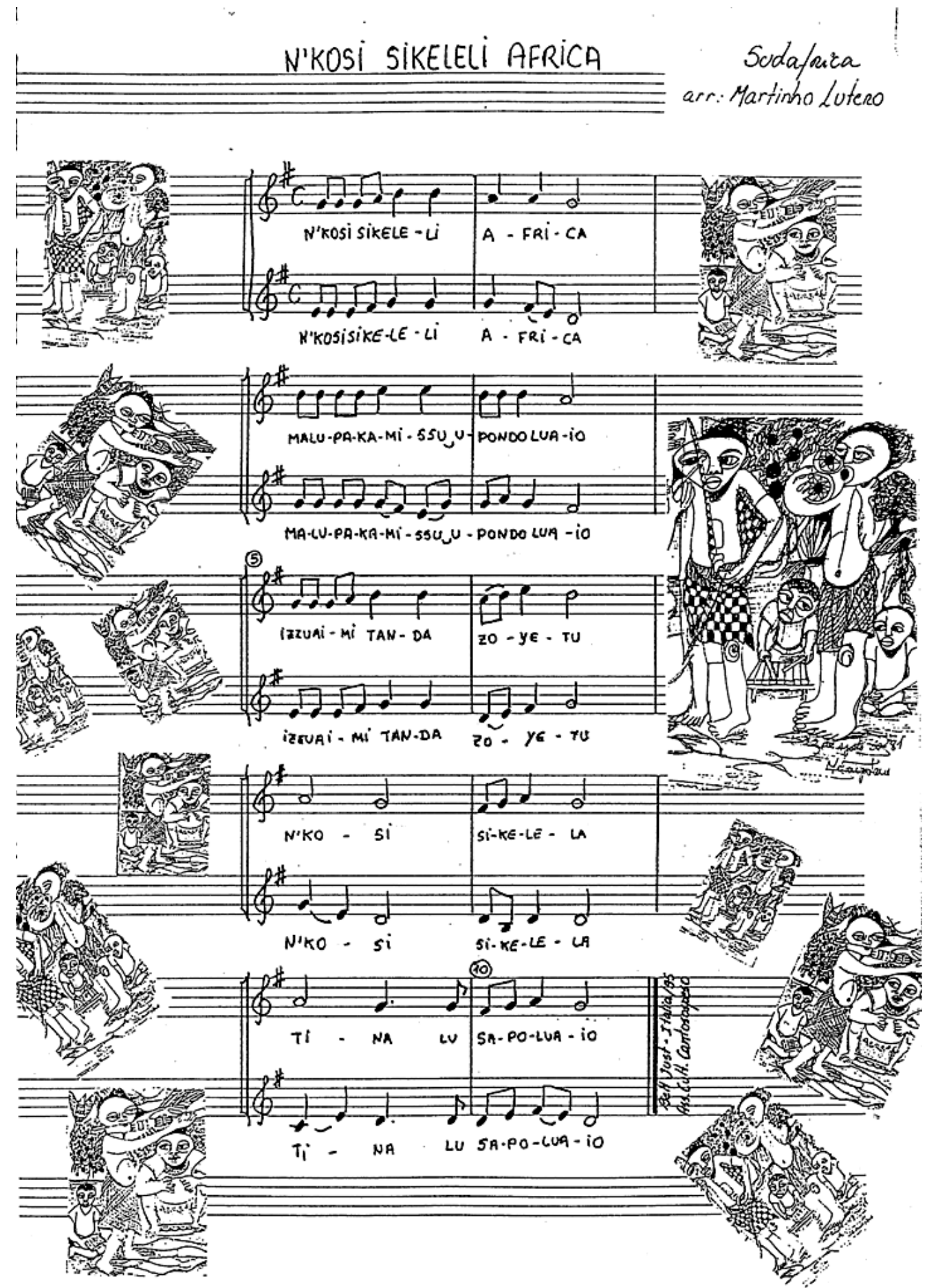




\section{ANEXO TT}

Partitura de N'Kosi Sikeleli Africa (2)

Arranjo a quatro vozes mistas: Martinho Lutero

Edição: La fabbrica del Suono - ACC

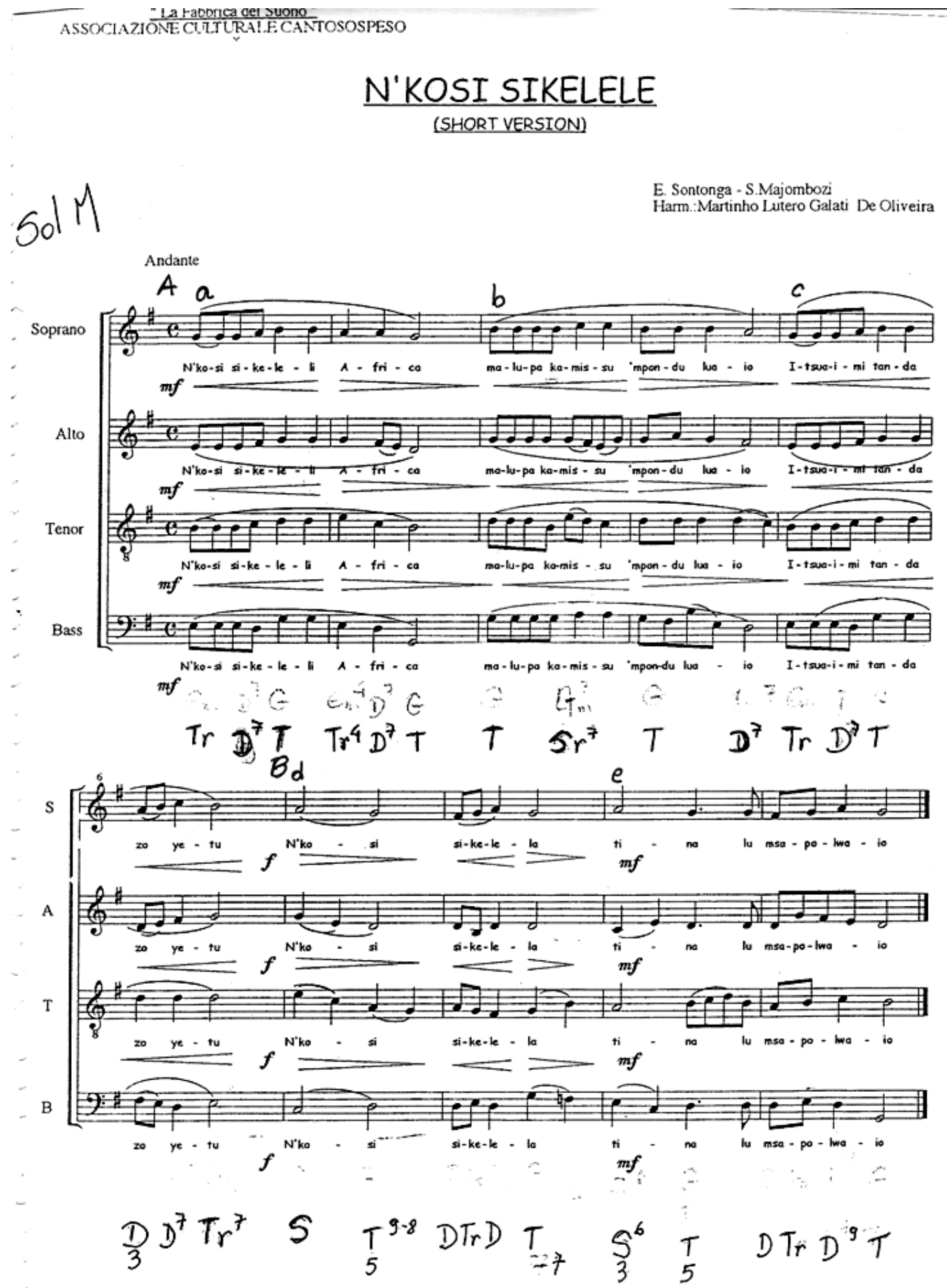


204

ANEXO UU

Letra de Tzun Tiãn Lai em mandarim e tradução em português feita por Kaling

春天来, 春天来。

花禿朵朵阙

红花明。向花闻

蜜蜂蝴蝶都

称来

Chejou primaresa

Tedar arflow

se atruaur

Flon venallea

Flor hanea

Abalha

borkoleta

vem chesendo

KALING

do

$\frac{\text { templo Zulai }}{\text { a }}$ 


\section{ANEXO V V}

Romanização no sistema Pinyin e letra em mandarim de Tzun Tiãn Lai, realizado por Chen Lijin
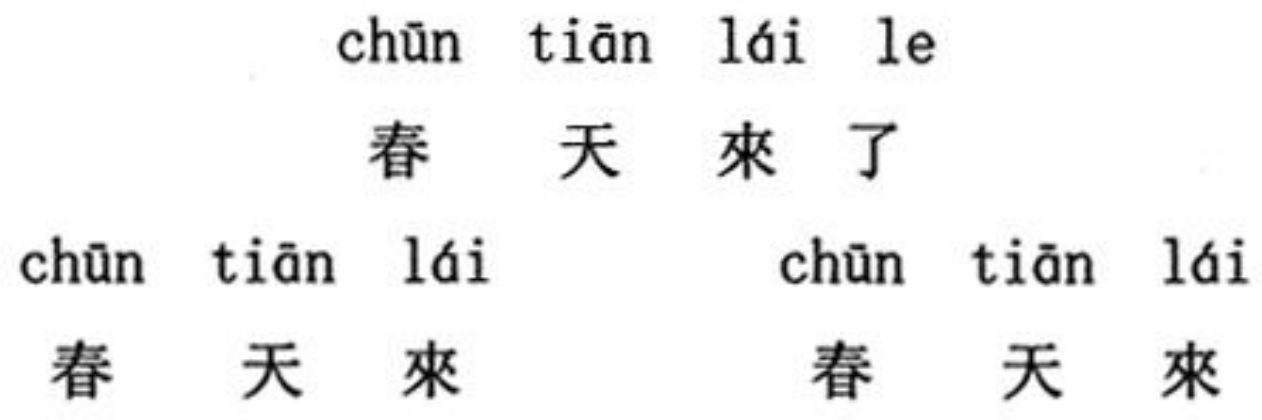

huã ér duǒ duǒ kãi

花兒朵朵 開

hơng huā kāi bái huã kāi

紅 花 開 白 花 開

mì fēng hú dié dōu fēi lái

蜜蜂 蝴 蝶 都 飛 來 


\section{ANEXO WW}

Partitura de Tzun Tiãn Lai (1)

Canção em mandarim

Arranjo realizado neste estudo pela mestranda
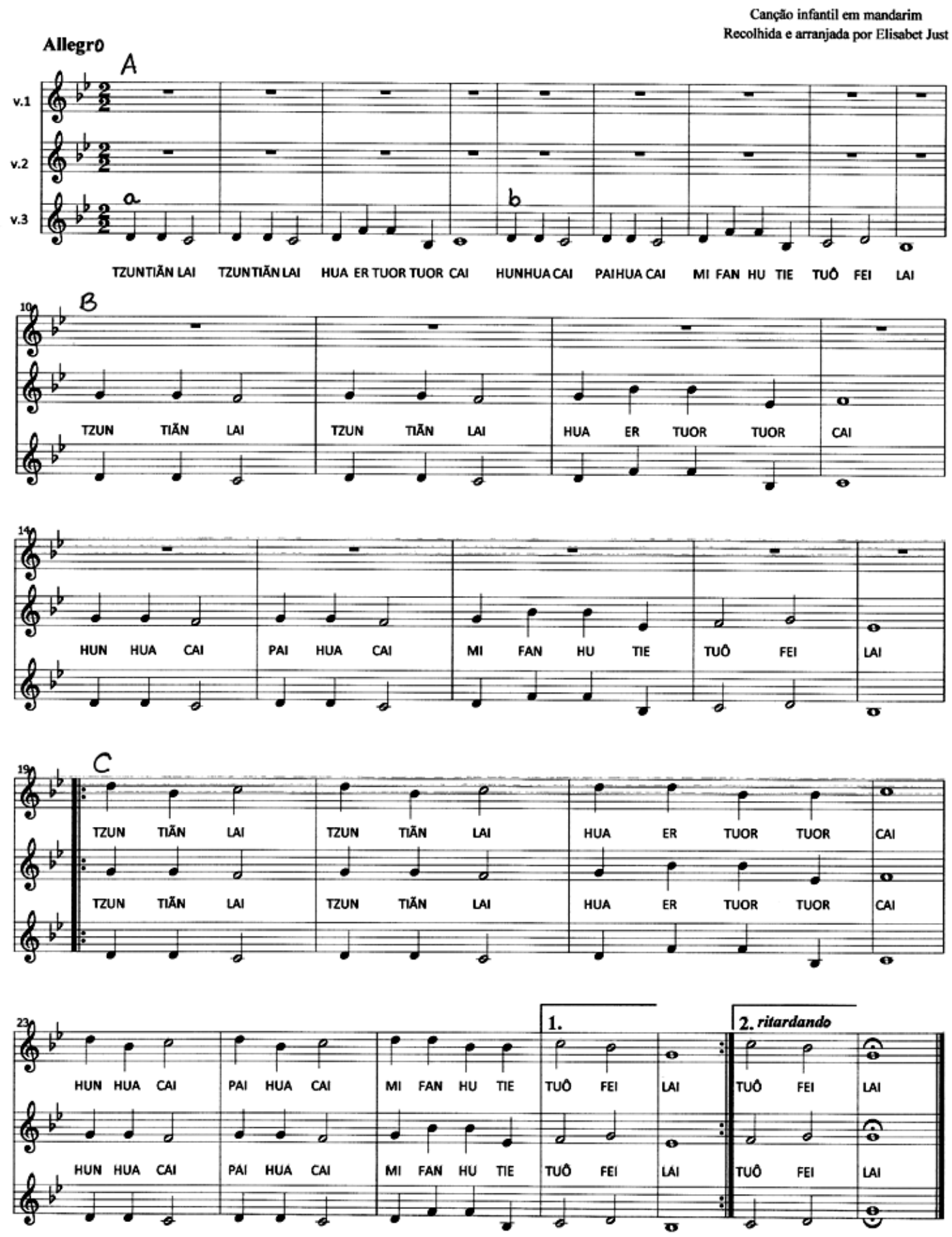


\section{ANEXO XX}

Partitura de Tzun Tiãn Lai (2)

Canção em mandarim

Arranjo: Bett Just

\section{ZUN TIN LAI}
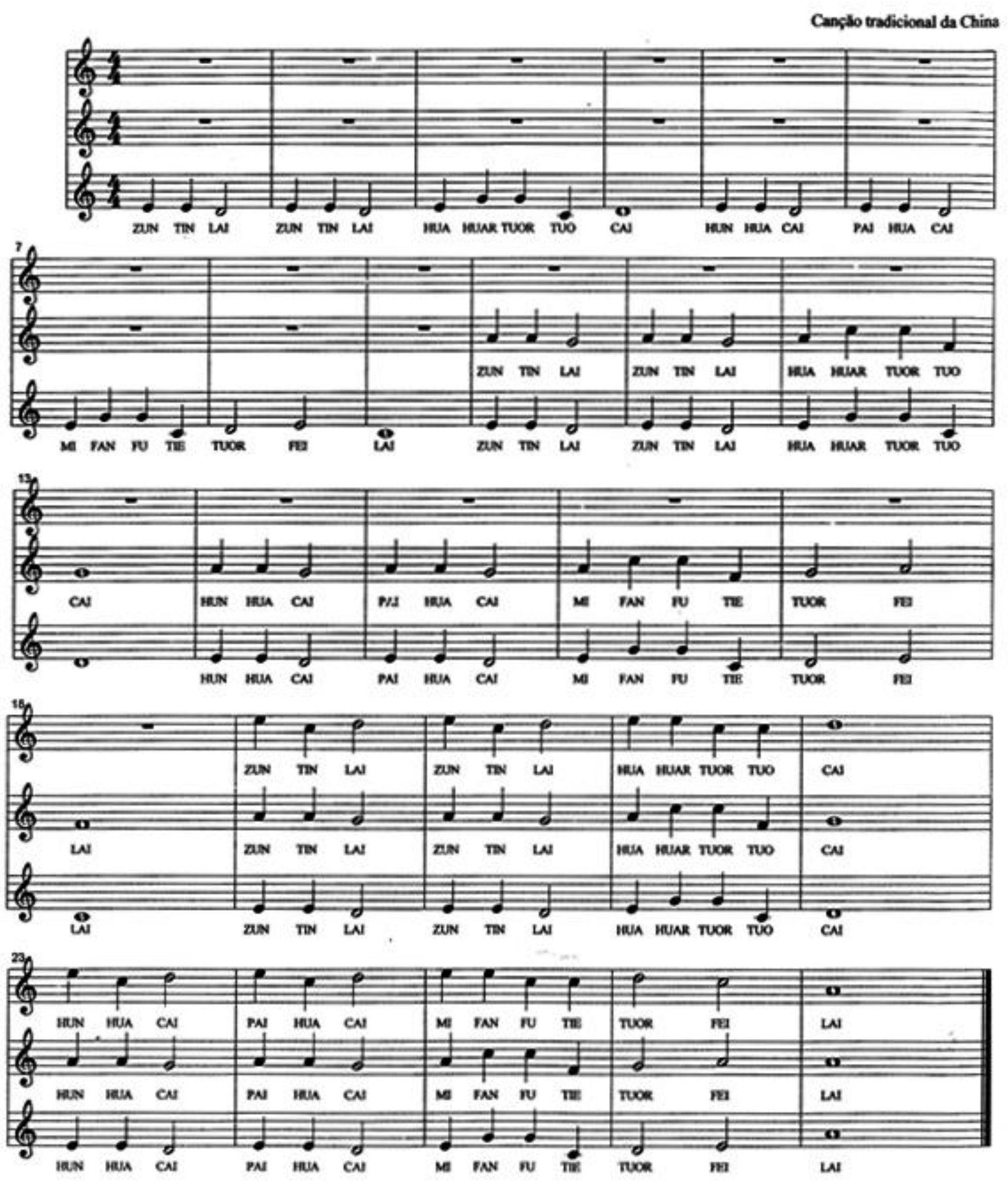
ANEXOS

Cap. 3 


\section{ANEXO YY}

Jogo da memória

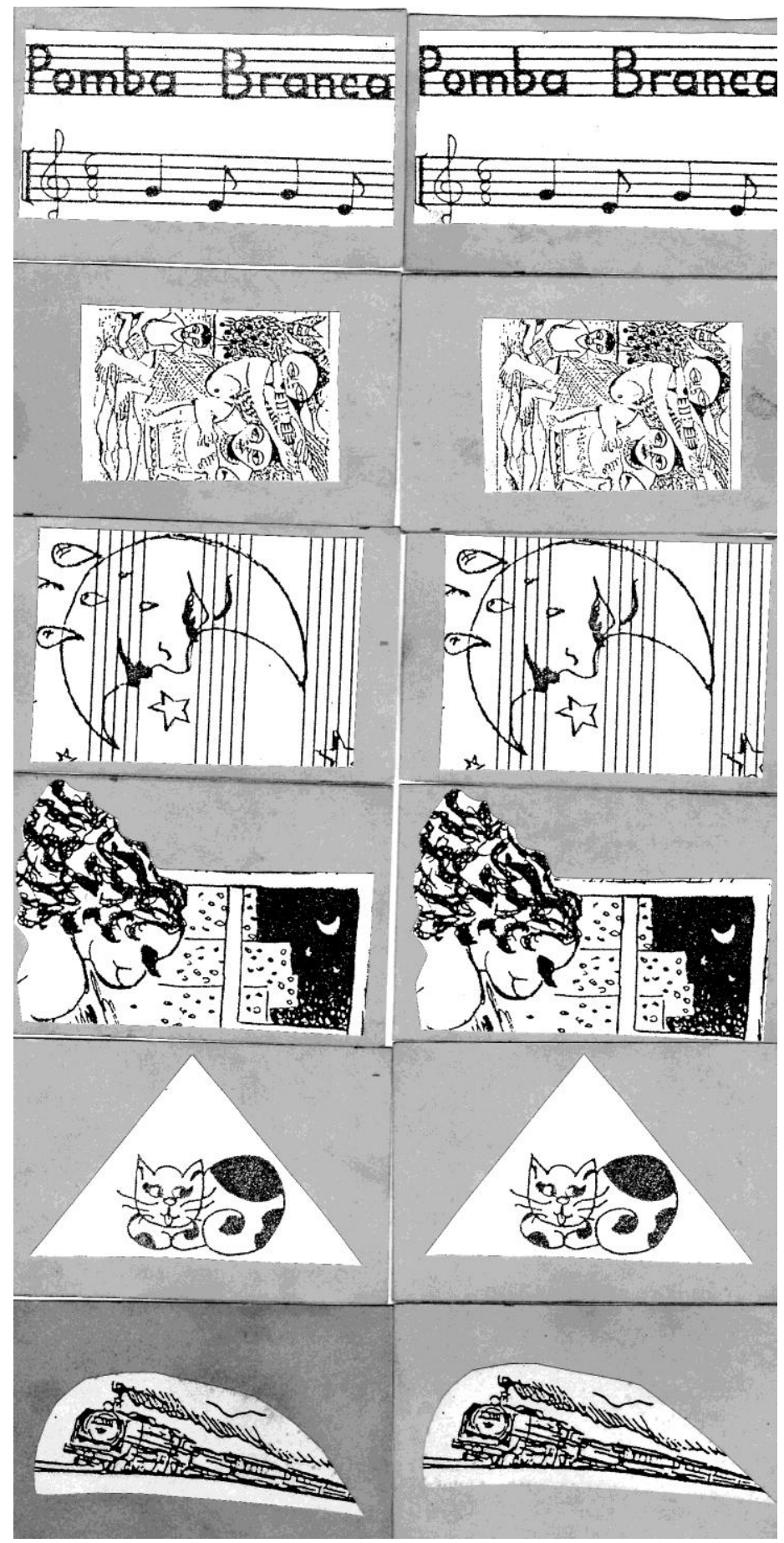


ANEXO ZZ Depoimentos das crianças do Curumim (julho de 2013)
Carlotta Broglio e Danae Rikos

\section{- Carlotta Broglio}

E' passato molto tempo da quando ho iniziato a cantare nel coro dell'Umanitaria. Nonostante questo ho dei ricordi lucidi e vivi di quell'esperienza. Oltre a ricordare ancora delle intere canzoni, come le imparavamo e le attività che suolgevamo durante le lezioni, la cosa che più mi è rimasta nell'anima è il senso di appartenenza ad un gruppo. il saper lavorare assieme e dover rispettare gli altri. Cantare tutti insieme a più voci non era una cosa facile per dei bambini. Tutti dovevamo impegnarci: se soltanto uno di noi sbagliava tutta la canzone veniva male. Ogni elemento del coro era importante. Insieme si riusciva a realizzare qualcosa di magico. Abbiamo giocato, imparato canzoni in lingue diverse, registrato in un vero studio di registrazione e ci siamo spesso esibiti davanti ad un pubblico (i nostri genitori e parenti, owviamente!) e tutto questo non sarebbe stato così bello se non fosse stato per le nostre due insegnanti: Claudia e Elisabet. $E^{\prime}$ stata un'immensa gioia potermi mettere in contatto con Elisabet e rendermi conto che anche lei si ricordava di me e della mia passione per una canzone del nostro repertorio "La lune est mort".

Carlotta Broglio

Sicuramente l'esperienza nel coro ha contribuito a farmi diventare quella che sono ora.

La mia scelta di studi si è orientata verso il mondo delle Belle Arti e probabilmente il coro mi ha aiutato a scroprire chi sono e cosa voglio fare.

Grazie a voi Claudia e Eisabet

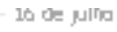

Danae Rikos

La mia esperienza al coro curumin è stata tra le piu significative della mia vita. Ho iniziato a cantare nel coro quando avevo solo 5 anni e da quel momento io e la musica siamo diventate una cosa sola. Fare parte del coro e soprattutto avere delle insegnanti come la bech e la claudia mi ha trasmesso la passione per il canto.,tutto é iniziato li. Mi ricordo ancora le lezioni di canto che aspettavo con tanta gioia e i primi concerti..quel periodo é stato dawvero tra i piu istruttivi. Mi ritengo una persona fortunata perche grazie al coro ho conosciuto la musica, il canto...grazie a voi ora continuo a studiare canto, perche ho deciso d far diventare la musica la mia professione. Vi saró per sempre riconoscente. 
